

\section{DISCLAIMER}

This report was prepared as an account of work sponsored by an agency of the United States Government. Neither the United States Government nor any agency Thereof, nor any of their employees, makes any warranty, express or implied, or assumes any legal liability or responsibility for the accuracy, completeness, or usefulness of any information, apparatus, product, or process disclosed, or represents that its use would not infringe privately owned rights. Reference herein to any specific commercial product, process, or service by trade name, trademark, manufacturer, or otherwise does not necessarily constitute or imply its endorsement, recommendation, or favoring by the United States Government or any agency thereof. The views and opinions of authors expressed herein do not necessarily state or reflect those of the United States Government or any agency thereof. 


\section{DISCLAIMER}

Portions of this document may be illegible in electronic image products. Images are produced from the best available original document. 


\title{
Revegetation Research on Oil Shale Lands in the Piceance Basin
}

\author{
EDWARD F. REDENTE \\ AND \\ C. WAYNE COOK

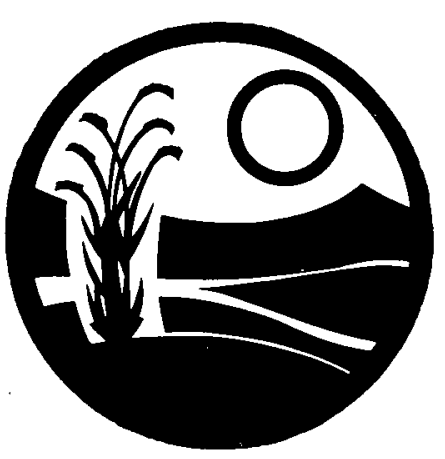 \\ Department of Range Science \\ Colorado State University \\ Fort Collins, Colorado 80523
}

Submitted

February 1981

\section{Prepared for}

U.S. Department of Energy

Under Contract No. DE-AS02-76EVO4018
DISCLAIMER

This book was preaared as an account of work sponsored by an agency of the United States Government. Neither the United Stales Government nor any agency thereol, nor any of their employees, makes any warraniy, express or implied, or assumes any legal liability or responsibility for the accuracy. represents that is use would not intringe priva:ely owned rights, Reterence herein to any specitic commercial product. process, or service by crade name, rrademark, manufacturer, or otherwise, docs not necessarily constitute or imply its endorsernent, recommendation. of tavoring by the United States Governtrient or any agency thereol. The views and opinions of authors expressed herein do not necessarily state or reflect those of the United States Government of any agency thereot.

\section{Entitled \\ REHABILITATION POTENTIAL AND PRACTICES FOR COLORADO OIL SHALE LANDS}

PROGRESS REPORT 1980-1981 


\section{ABSTRACT}

The overall objective of this project is to study the effects of various reclamation practices on above- and belowground ecosystem development associated with disturbed oil shale lands in northwestern Colorado. Plant growth media that are being used in field test plots include retorted shale, soil over retorted shale, subsoil materials, and surface disturbed topsoils. This project was initiated in June 1975 and is presently reporting on $f$ ifth-year data.

Satisfactory stands of vegetation failed to establish on unleached retorted shale during two successive years of seeding (1977 and 1979). Only salt-tolerant species produced any measureable biomass during the second year's planting (1979), and these produced less than $200 \mathrm{~kg} / \mathrm{ha}$. Straw mulch and additions of nitrogen and phosphorus had little effect upon establishing vegetation on retorted shale. Coverings of topsoil over retorted oil shale $(30 \mathrm{~cm}, 61 \mathrm{~cm}$, and $91 \mathrm{~cm})$ showed increased herbage production from seeded species, both native and introduced, with increased depth of soil covering. All seedings with soil over retorted shale were judged to be successful at the end of three growing seasons, but deep-rooted shrubs that depend upon subsoil moisture may have their growth hampered by the retorted shale substrate.

Natural revegetation on areas with various degrees of disturbance shows that natural invasion and succession was slow at best, but invading species and biomass production was greatest on the least disturbed and least on the most severely disturbed soils. Plants that are nonmycorrhizal appear to be the first invaders on severely disturbed areas. Yearly environmental fluctuations and severity of disturbance appear to be the primary factors in determining rates of natural invasion and succession on disturbed native rangelands.

Invasion of species on disturbed topsoil plots showed that after three years introduced seed mixtures were more effective than native mixtures in occupying space and closing the community to invading species. Fertilizer appears to encourage the invasion of annual plants even after the third year following application.

Long-term storage of topsoil without vegetation significantly decreases the mycorrhizal infection potential and, therefore, decreases the relative success of aboveground vegetation and subsequent succession. Severe disturbance of soils, use of fertilizer, and soil stockpiling can all adversely affect the microbial processes essential for establishment of plant communities in mined land reclamation. In general, treatments that increase the production of organic matter in the soil increase microbial activity. Microbiological activity in retorted oil shale is minimal. and shows a direct negative effect when mixed with topsoil.

Ecotypic differentiation related to growth and competitive ability, moisture stress tolerance, and reproductive potential have been found in five native shrub species. From this work it is possible to predict the appropriate species combinations or ecotypes that are best suited for different landscape reclamation.

Germplasm sources of two grasses and two legumes, that have shown promise as revegetation species, have been collected and evaluated for the production of test seed. Suitable breeding procedures are being used to develop improved strains which will eventually increase the availability of native plant materials for disturbed land reclamation.

The use of fertilizer in the reclamation of disturbed soils remains questionable. Fertilizer (nitrogen) when added to the soil at the time of planting may encourage competition fromannual weeds to the detriment of seeded species. Likewise, fertilizers may promote grass growth to the extent that it decreases the growth of other life forms. Heavy applications of nitrogen are lost from the soil and are, therefore, not as suitable as smaller annual applications following seedling establishment.

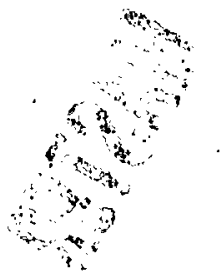

This report was prepared as an.account of work sponsored by the United States Government. Neither the United States nor the United States Department of Energy, nor any of their employees, makes any warranty express or. implied, or assumes any legal liability or responsibility for the accuracy, completeness, or usefulness of any information, apparatus, product or process disclosed or represents that its use would not infringe privately owned rights. 


\title{
TABLE OF CONTENTS
}

\author{
EFFECTS OF PLANT SPECIES, SOIL MATERIAL, AND CULTURAL PRACTICES UPON
}

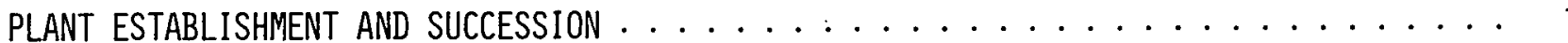

OBJECTIVES

RESULTS TO DÄE

Direct Revegetation of Retorted Shale.........................

Introduction .........................

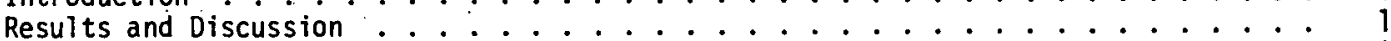

Effects of Seed Mixture ......................... 3

Retorted Shale Successional Study . . . . . . . . . . . . . . . . . . . . 5

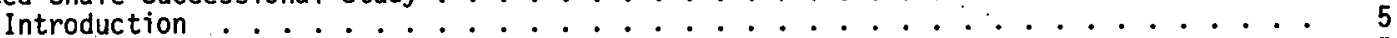

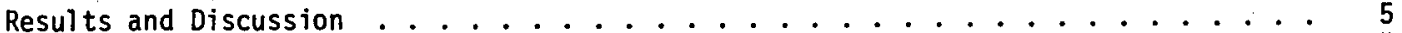

Effects of Topsoil Depth Over Retorted Shaie . . . . . . . . . . . . 5

Effects of Seed Mixture.......................... 7

Effects of Fertilizer ..................... 8

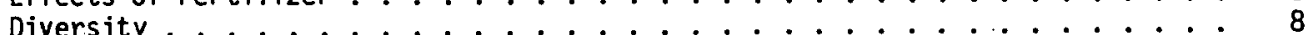

Conclusions . . . . . . . . . . . . . . . . . . . . . . 10

Annual Disturbance Plot Study . . . . . . . . . . . . . . . . . . . 11

Introduction

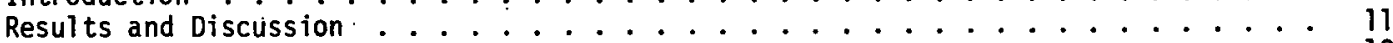

Conclusions . . . . . . . . . . . . . . . . . . . . ..... . 13

Invásion as Related to Revegetation Practices on Surface Disturbed Soils . . . . . . . 13

Introduction

Results and Discussion ........................ 14

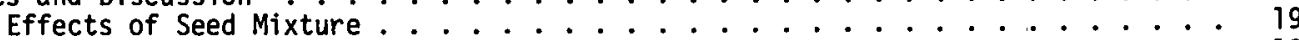

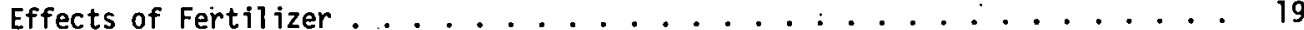

Effects of Mulch ...................... . . . 20

Appl ications for Reclamation Practices ................. 2

Revegetation Techniques Study . . . . . . . . . . . . . . . . . . . . . . 21

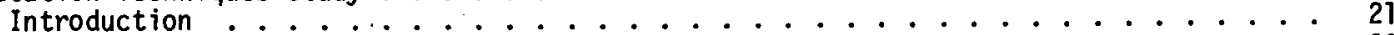

Results and Discussion ......................... . . . . . . . . . . . . . 33

Effects of Rockiness

Effects of Seed Mixture ...................... 25

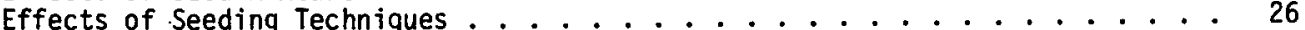

Effects of Fertilizer..................... . . . . 27

Effects of Irrigation ................... 28

Vegetation Successional Trend.................... 28

Conclusionsity . . . . . . . . . . . . . . . . . . . . . . . . . . . 28

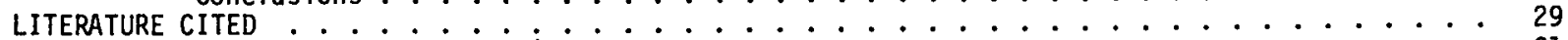

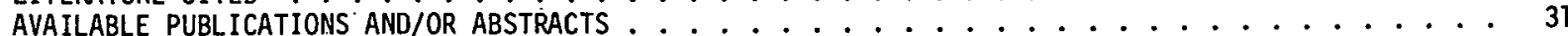

SOIL MICROORGANISMS AND METHODS OF RETORTED SHALE RECLAMATION $\ldots \ldots \ldots \ldots$

OBJECTIVES

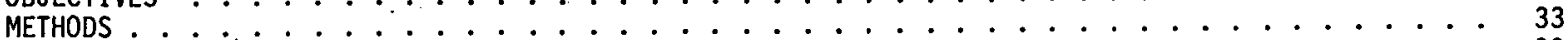

Study Site

Soil Sampling . . . . . . . . . . . . . . . . . . . . . . . . 33

General Analytical Procedures . . . . . . . . . . . . . . . . . . . . 33

Plant-Associated Nitrogen Fixation Potential . . . . . . . . . . . . . . . . 33

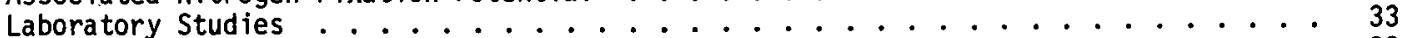

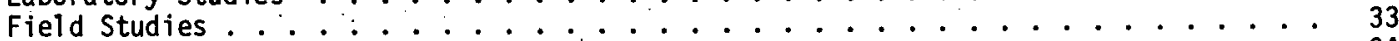

Shale Extraction Experiments . . . . . . . . . . . . . . . . . . . . . . 34 
Nitrification Activity Measurements . . . . . . . . . . . . . . . . . . . . . 34

Ammonium Ion Effects on Nitrogen Fixation in Soil-Shaje Mixtures . . . . . . . . . . 34

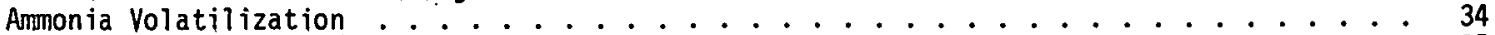

Statistical Analysis . . . . . . . . . . . . . . . . . . . . . 35

RESULTS

Revegetation Technqiues plot . . . . . . . . . . . . . . . . . . . . . . 35

Long-Term Fertility Plots............................. 36

Successional Plot . . . . . . . . . . . . . . . . . . . . . . . . . 36

Annual Disturbance Plots . . . . . . . . . . . . . . . . . . . . . . . . . . 37

Retorted Shale Successional Plot . . . . . . . . . . . . . . . . . . . . . 37

Stored Soil Experiment ................................ 38

Retorted Shale Effects on Soil Microbiological Processes .................. 41

Retorted Shale and Anmonium Ion Effects on Nitrogen Fixation Potential . . . . . . . . . 41

Ammonia Volatilization . . . . . . . . . . . . . . . 41

Plant-Associated Nitrogen Fixation Potential . . . . . . . . . . . . . . . . 42

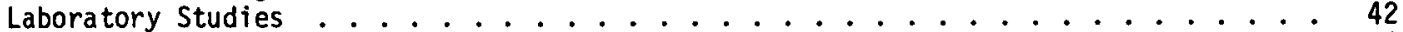

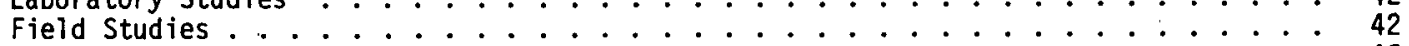

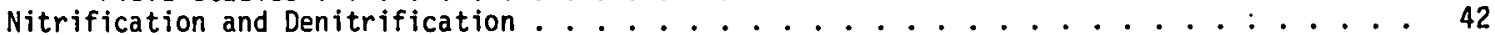

DISCUSSION .......................443

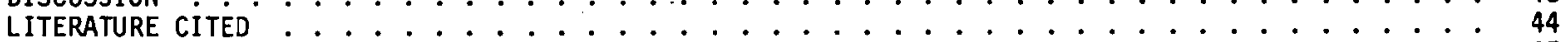

AVAILABLE PUBLICATIONS AND/OR ABSTRACTS . . . . . . . . . . . . . . . . . . . . 45

IMPORTANCE OF FUNGI IN REVEGETATING DISTURBED SOILS AND RETORTED SHALE $\ldots \ldots \ldots$

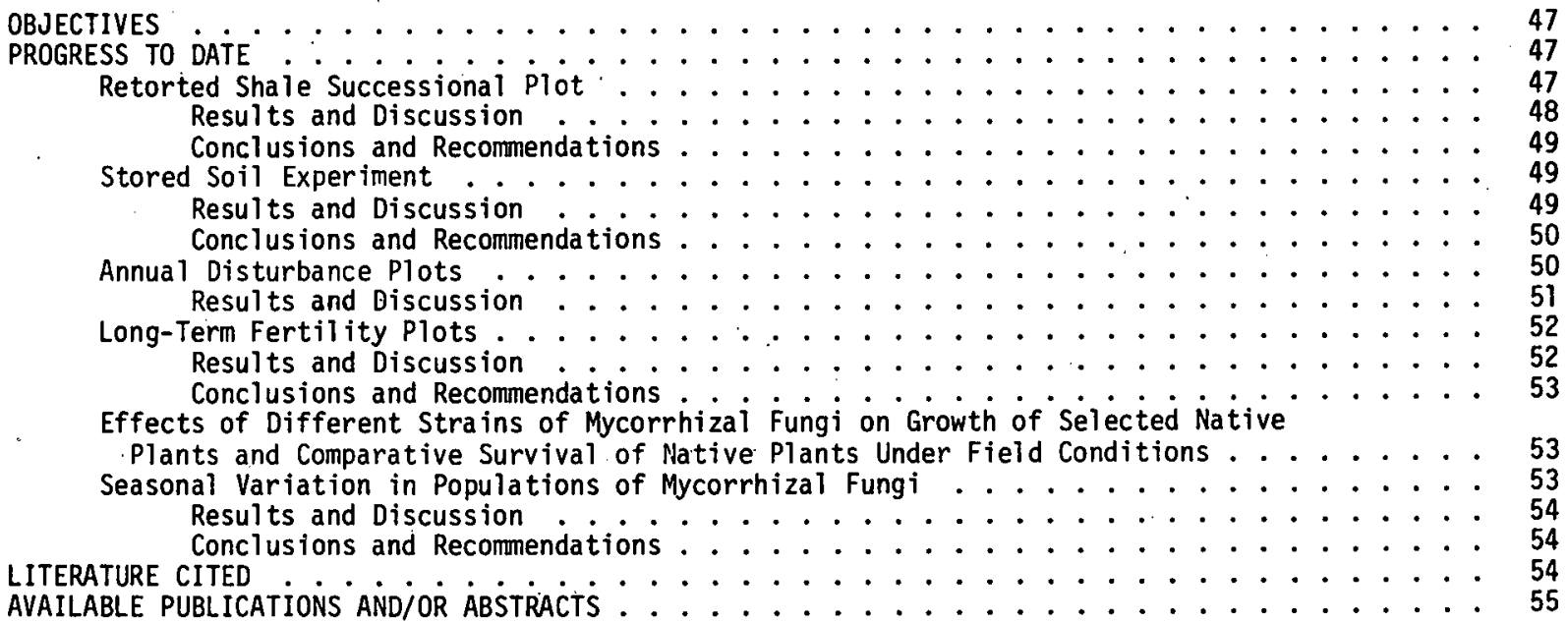

LONG-TERM FERTILITY STUDY ON LAND DRASTICALLY DISTURBED BY

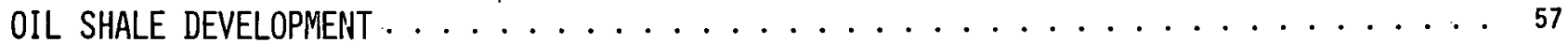

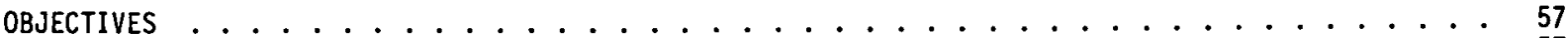

METHODS . . . . . . . . . . . . . . 57

RESULTS AND DISCUSSION . . . . . . . . . . . . . . . . . . .

Soil Data for Subsoil plots . . . . . . . . . . . . . . . . . . . . .

Vegetation Data for Subsoil Plots . . . . . . . . . . . . . . . . . . . 61

So il Data for Topsoil Plots ............................ 6 62

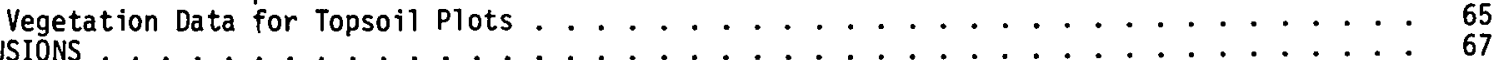

LITERATURE CITED .

AVAILABLE PUBLICATIONS AND/OR ABSTRACTS . . . . . . . . . . . . . . . . . . . . 68 
ECOGENETIC VARIABILITY IN NATIVE SHRUBS AND THE STRUCTURE OF NATURAL COMMUNITIES AS RELATED TO THE REESTABLISHMENT OF VEGETATION ON

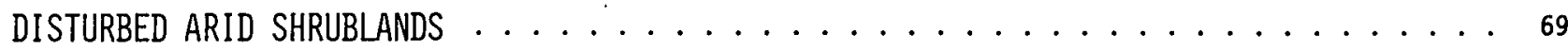

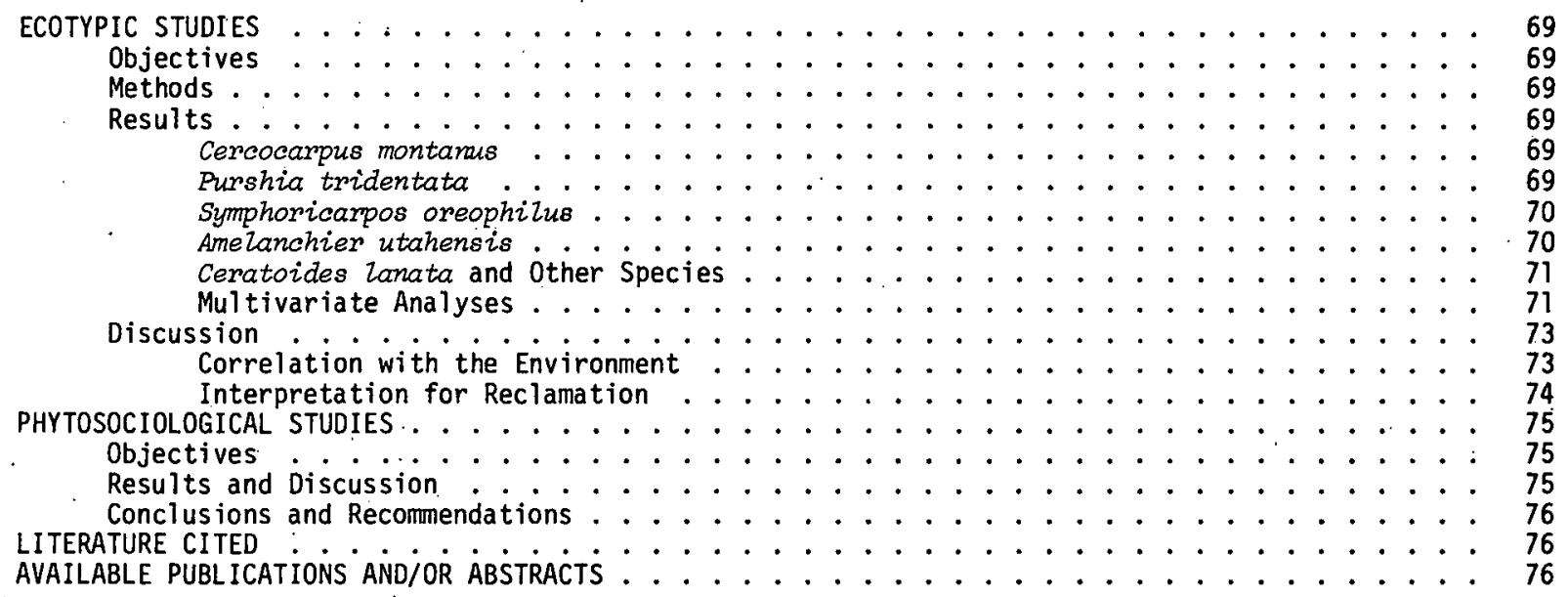

SELECTION OF NATIVE GRASSES AND LEGUMES FOR IMPROVED REHABILITATION $\ldots \ldots \ldots$

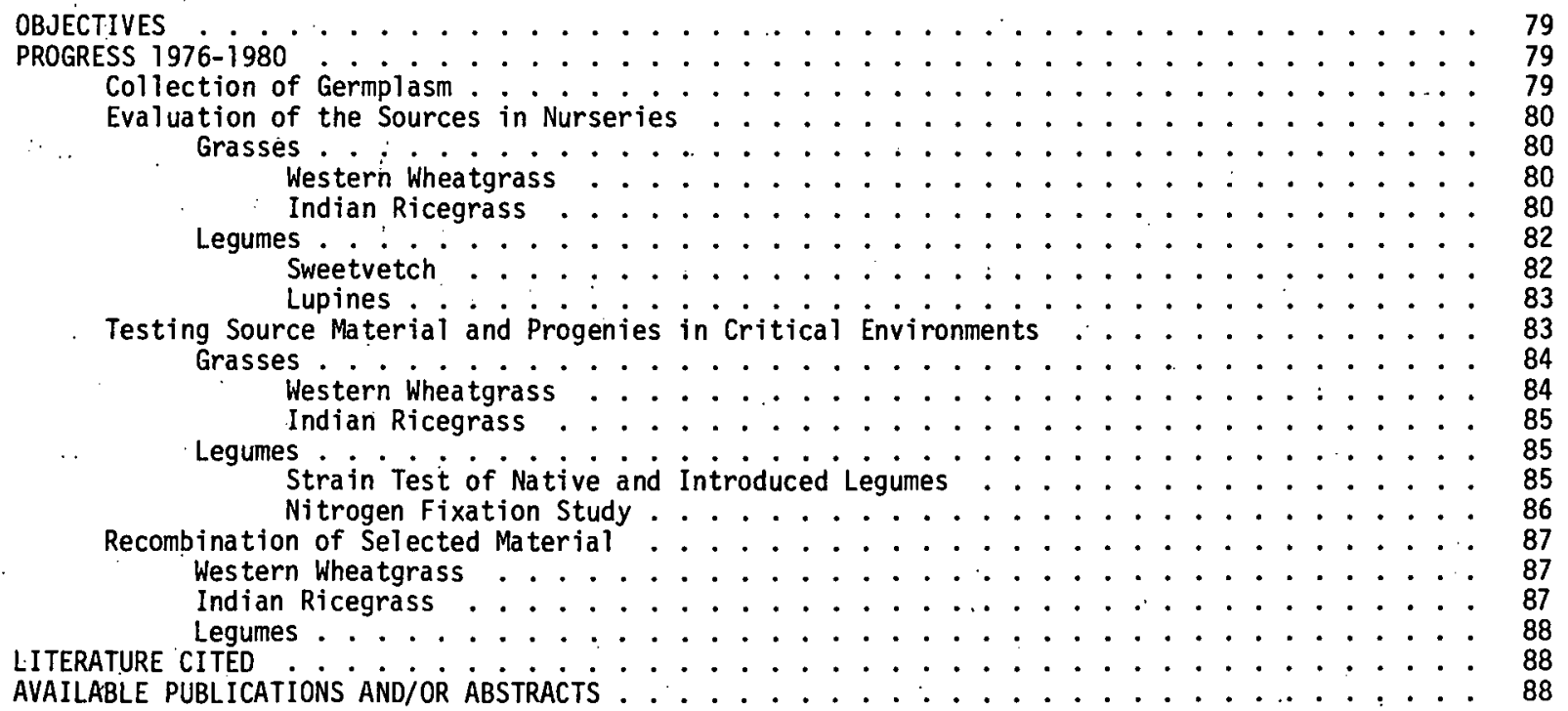




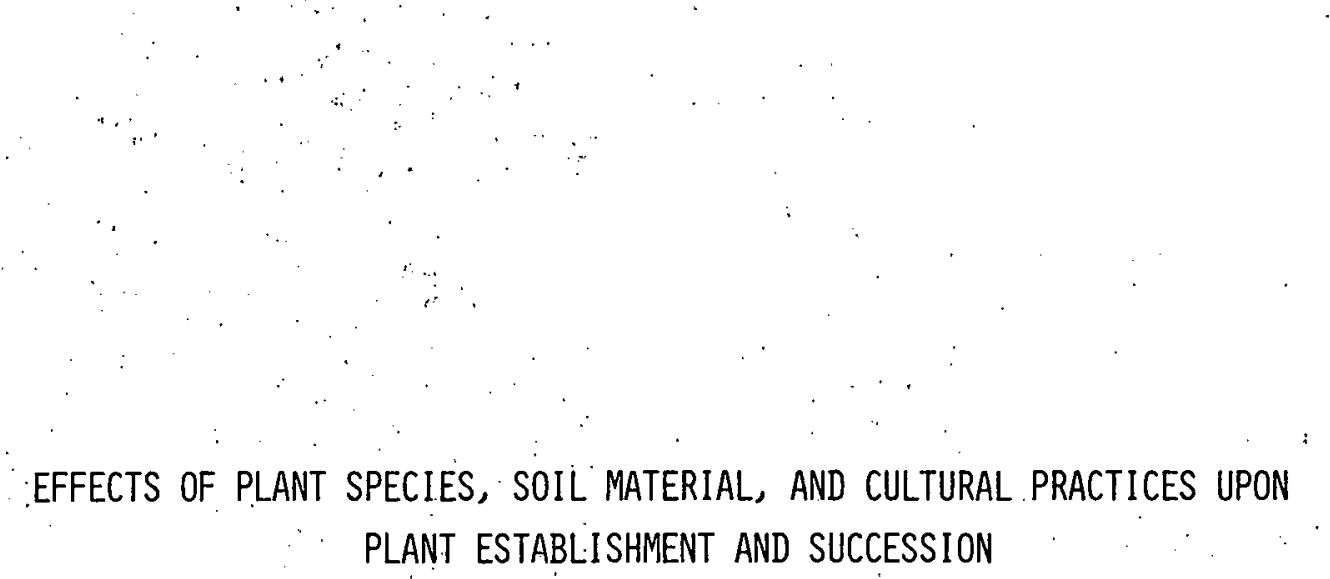

Edward F. Redente, Ted B. Doerr, Carl B. Mount, Carolyn E. Grygiel, - Thomas E. Sievers, and Mario Biondini

Department of Range Science

Colorado State University

Fort Colzins, Colorado 80523

$\because \therefore \quad \therefore$.

OBJECTIVES

This subproject has several interrelated objectives.directed toward the establishment of diverse, functional, and self-sustaining ecosystems with a minimum input of amendments. The results from this subproject will uitimately serve to provide procedures for establishing effective plant communities on lands disturbed by oil shale mining and retorting processes. Various plant species mixtures (native and introduced), planting techniques, fertilization treatments, mulch, and irrigation are being tested on disturbed soils, retorted oil shale, and soil over retorted shale material. The specific objectives of the research include: (1) determining proper seeding practices of potentially usable mixtures of plant species and their relationship to cultural practices such as fertilization, irrigation, and mulching, (2) determining the rate and direction of plant succession on disturbed topsoil, subsoil, overburden, retorted shale, and retorted shale overlain by soil as influenced by natural invasion, species mixtures, and cul tura? practices, and (3) determining proper management procedures for long-term stabilization and reclamation of retorted shale materials.

RESULTS TO DATE

Direct Revegetation of Retorted Shàle

\section{Introduction}

In the fall of 1979 the treatment using no topsoll covering over retorted shale was refertilized and reseeded to make a second attempt at establishing a viable plant community. For this reason, the Shale-to-Surface treatment was not included in the Retorted Shale Successional Study analys is but rather is included in this study.

The Shale-to-Surface panel was refertilized with three combinations of nitrogen and phosphorus which were:

\section{1. $56 \mathrm{~kg} \mathrm{~N} / \mathrm{ha}, 672 \mathrm{~kg} \mathrm{P} / \mathrm{ha}$}

\section{2. $56 \mathrm{~kg} \mathrm{~N} / \mathrm{ha}, 448 \mathrm{~kg} \mathrm{P} / \mathrm{ha}$ \\ 3. $56 \mathrm{~kg} \mathrm{~N} / \mathrm{ha}, 224 \mathrm{~kg} \mathrm{P} / \mathrm{ha}$}

High rates of phosphorus were chosen because results from greenhouse studies indicated that Paraho retorted shale was deficient in phosphorus, and this severely limited plant growth. Just prior to seeding, fertilizer was incorporated into the shale material using a tractor-mounted rototiller. The area was then broadcast seeded using three seed mixtures composed of either all native, all introduced, or all salt-tolerant species (Table 1). Following broadcast seeding the area was lightly raked to cover the seed. A mulch consisting of seed-free wheat straw was spread over the entire area at the rate of $2.2 \mathrm{MT} / \mathrm{ha}$. This was done to reduce surface temperatures, moderate temperature fluctuations, and improve moisture conditions for germination and emergence.

\section{Results and Discussion}

Vegetation failed to establish on the Shale-toSurface treatment following initial seeding and fertilization in 1977. Vegetation failure can be explained on the basis of many inherent chemical and physical properties of Paraho retorted shale which are detrimental to seed germination and plant growth. Those chemical properties which were considered to be of prime importance to plant growth were measured in 1977 and 1980 to provide some comparison of how these properties are changing with continued exposure of the retorted shale to natural weathering (Table 2). The soil testing procedures used were developed for use on natural surface soil material and relate biological productivity to the parameters measured. However, no such relationships have been established for retorted shale. Since the analyses on both unweathered and naturally weathered retorted shale utilize the same procedures, useful comparisons can be made between the results obtained. After three years of weathering, the $\mathrm{pH}$ of Paraho retorted shale is still high and is considered to be strongly alkaline. High $\mathrm{pH}$ is presumed detrimental to plant growth because it reduces uptake of such essential plant nutrients as nitrogen, phosphorus, iron, manganese, copper, and zinc (California Fertilizer Association 1980). Tisdale and Nelson (1975) and Brady (1974) noted that increased $\mathrm{pH}$ allowed 
Table 1. Seed mixtures used on the Retorted Shale-to-Surface Study.

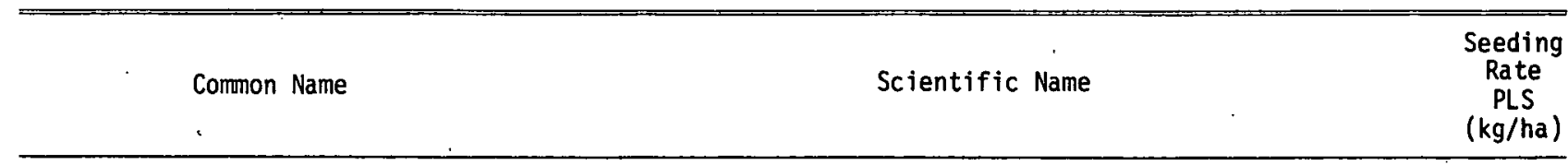

Mixture A--Salt-tolerant species

1. Jose tall wheatgrass

2. Rosana western wheatgrass

3. Critana thickspike wheatgrass

4. Oahe intermediate wheatgrass

5. Slender wheatgrass

6. Vinal Russian wildrye

7. Madrid yellow sweetclover

8. Ladak alfalfa

9. Strawberry clover

10. Fourwing saltbush

11. Shadscale saltbush

12. Mat saltbush

13. Castle Valley clover

14. Gardner saltbush

15. Winterfat

Mixture B--Native species

1. Beardless bluebunch wheatgrass

2. Sodar streambank wheatgrass

3. Rosana western wheatgrass

4. Paloma Indian ricegrass

5. Green needlegrass

6. Sweetvetch

7. Lewis flax

8. Paimer penstemon

9. Big sagebrush

10. Fourwing saltbush

11. Curlleaf mountain mahogany

12. Winterfat

Mixture C--Introduced species

1. Nordan crested wheatgrass

2. Jose tall wheatgrass

3. Oahe intermediate wheatgrass

4. Siberian wheatgrass

5. Luna pubescent wheatgrass

6. Regar meadow brome

7. Vinal Russian wildrye

8. Lutana cicer milkvetch

9. Ladak alfalfa

10. Madrid yellow sweetclover

11. Small burnet

12. Siberian peashrub

13. Russian olive
Agropyron elongatum Agropyron smithii

4.48

Agropyron dasystachyum

Agropyron intermedium

Agropyron trachycaulion

Elymus junceus

Melilotus officinalis

Medicago sativa

Trifolium fragiferm

Atriplex canescens

Atriplex confertifolia

Atriplex corrugata

Atriplex cuneata

Atriplex gardneri

Ceratoides Lanata

2.24

1.12

2.24

2.24

1.12

1.12

1.12

1.12

4.48

4.48

2.24

3.36

2.24

4.48

Agropyron inerme

2.24

Agropyron riparium

1.12

Agropyron smithii

2.24

Oryzopsis hymenoides

1.12

Stipa viridula

1.12

Hedysamm boreale

Linum lewisii

6.72

1.12

Penstemon palmeri

Artemisia tridentata

0.56

Atriplex canescens

0.056

Cercocarpus ledifolius

4.48

Ceratoides lanata

4.48

Agropyron cristation

Agropyron elongatum

Agropyron intermedium

Agropyron sibericum

Agropyron trichophomm

Bromus erectus

Elymus junceus

Astragalus cicer

Medicago sativa

Melilotus officinalis

Sanguisorba minor

Caragana arborescens

Elaeagnus angustifolia

1.12

4.48

2.24

1.12

2.24

2.24

1.12

2.24

1.12

1.12

4.48

13.44

44.80

greater availability of molybdenum and boron to plants. The resulting copper/molybdenum imbalance and high boron levels have been noted as problems in retorted shale revegetation. Miltimore and Mason (1971) cautioned that copper to molybdenum ratios of less than two could result in molybdenosis in ruminants. Schwab et al. (1980) reported Cu/Mo ratios in dichotomous plants growing on the shallower topsoil treatments to be below this critical level and plants were concentrating boron to near phytotoxic levels. This could be one of the major reasons for plants failing to establish after initial seeding and fertilization of the Shale-toSurface treatment.

The electrical conductivity (EC) of weathered retorted shale shows the shale material to still be saline $(E C>4$ mmos $/ \mathrm{cm})$. The $1: 1$ extract value must be converted to a saturation extract value for comparison with tables relating plant growth to EC values. When converted, the value for the saturation extract is 12.2. This value indicates that 
Table 2. Comparison of chemical characteristics of fresh Paraho retorted shale and threeyear-old retorted shale with no topsoil covering.

\begin{tabular}{|c|c|c|}
\hline Chemical Characteristics & $\begin{array}{c}\text { Fresh } \\
\text { Retorted } \\
\text { Shale }\end{array}$ & $\begin{array}{c}\text { 3-Year-0ld } \\
\text { Retorted } \\
\text { Shale } \mathrm{e}^{t}\end{array}$ \\
\hline
\end{tabular}

Measurement

$\begin{array}{lrl}\mathrm{pH} & 9.6 & 8.7 \\ \mathrm{EC}\left(\text { mmhos } / \mathrm{cm}\left(25^{\circ} \mathrm{C}\right)^{5}\right. & 7.0 & 4.7 \\ \text { SAR } & 14.0 & 5.0\end{array}$

Cations (meq/1)

$\begin{array}{lrr}\mathrm{Ca} & 21.0 & 20.1 \\ \mathrm{Mg} & 3.9 & 20.9 \\ \mathrm{Na} & 49.2 & 23.6 \\ \mathrm{~K} & 4.7 & 3.1\end{array}$

tValues are averages of four samples taken at different depths in the shale profile.

5o convert $1: 1$ extract to a saturated paste reading, multiply by 2.6 (percent saturation is $38 \%$ ).

only highly salt-tolerant species would produce satisfactory yields even after weathering for three full years. The high salt content in the soil solution could bring about direct ion effects which may be phytotoxic. Sandoval and Gould (1978) noted that boron salts often accumulate in saline soil to phytotoxic levels, and this may be the case here. Also, high levels of carbonate salts could keep the $\mathrm{pH}$ of the shale at levels where plant roots could be damaged as a direct result of high $\mathrm{pH}$. Thorup (1969) has noted this effect on plants growing in solution culture.

The sodium adsorption ratio (SAR) of the retorted shale has dropped appreciably in three years because of two factors: sodium leaching and release of soluble magnesium compounds. These factors have reduced the sodium hazard on the Shaleto-Surface treatment to levels where excess sodium would not be a major problem if salt-tolerant plants were already established. However, some surface crusting of the shale has been noticed, and this is probably because sodium levels are still high enough to disperse the surface particles and cause crusting when the shale material dries (Striffler et al. 1974).

The fertility status of the retorted shale before amendments are added is unfavorable for plant growth. Although these parameters were not measured in 1980 , data from 1977 indicates that the retorted shale material contains adequate amounts of potassium but is very low in both nitrogen and phosphorus.

Physical properties which could be detrimental to seedling emergence and growth include shale surface crusting, high surface temperatures, and coarse texture. . Surface crusting caused by elevated sodium levels would have the effect of reduc- ing seedling emergence by direct physical obstruction and causing reduced water infiltration which would reduce soil moisture recharge. The black color of the retorted shale caused surface temperatures on bare shaie to reach $69^{\circ} \mathrm{C}$ during the midday periods of the summer months. Even on mulched areas, temperatures at the shale surface under the mulch reached $53^{\circ} \mathrm{C}$ which is still far above optimums for seed germination and seedling emergence (between $10^{\circ}$ and $30^{\circ} \mathrm{C}$ ) reported by McDonough (1977). Coarse texture, of course, reduces the water holding capacity of the shale. Therefore, treatments initiated in 1979 were aimed at moderating the many detrimental chemical and physical properties of the shale while trying to determine minimum treatments needed for plant growth directly on retorted shale.

Despite fertilization and mulching, vegetation that grew on the Shale-to-Surface treatment in 1980 consisted mostly of nonseeded species including Russian thistle (Salsola iberica) with lesser amounts of kochia (Kochia scoparia), and prickly lettuce (Lactuca serriola). of the species seeded, only wheatgrasses--tall wheatgrass (Agropyron elongatum), intermediate wheatgrass (A. intermedium), slender wheatgrass (A. trachycaulum), and western wheatgrass $(A$. smithi $i)$--showed cons istent emergence.

\section{Effects of Seed Mixture}

The wheatgrasses used in the salt-tolerant mixture (Table 1) consistently showed higher values for density, production, and cover than the other native or introduced wheatgrasses in the two remaining mixtures. Wheatgrasses from the introduced seed mixture (Table 1) showed values for production and cover which were higher than the native seed mixture. The production values from salt-tolerant and introduced seed mixtures were significantly higher for production than the wheatgrasses in the native seed mixture (Figures 1 and 2). However,

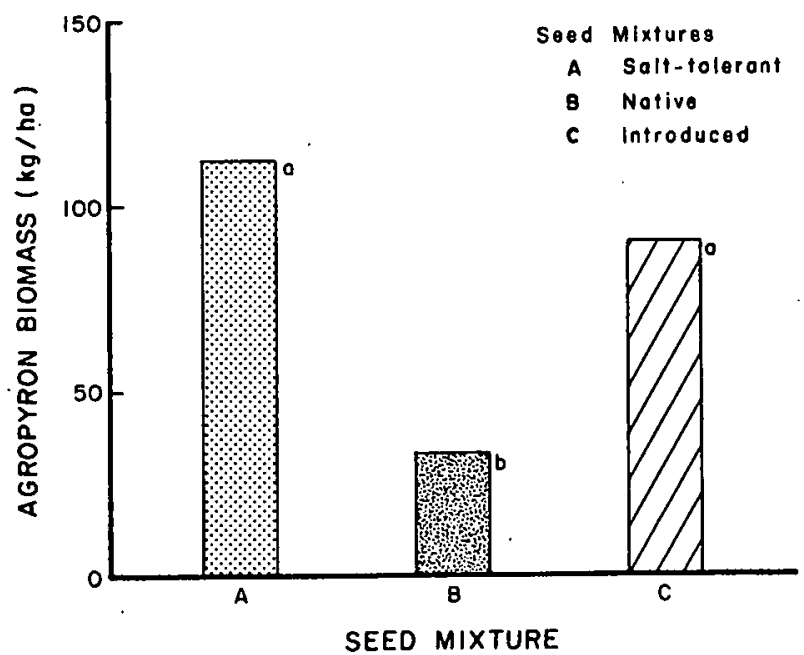

Figure.1. Wheatgrass biomass by seed mixture on the Shale-to-Surface treatment. (Values followed by different ietters are significantly different at $p=.10$.) 


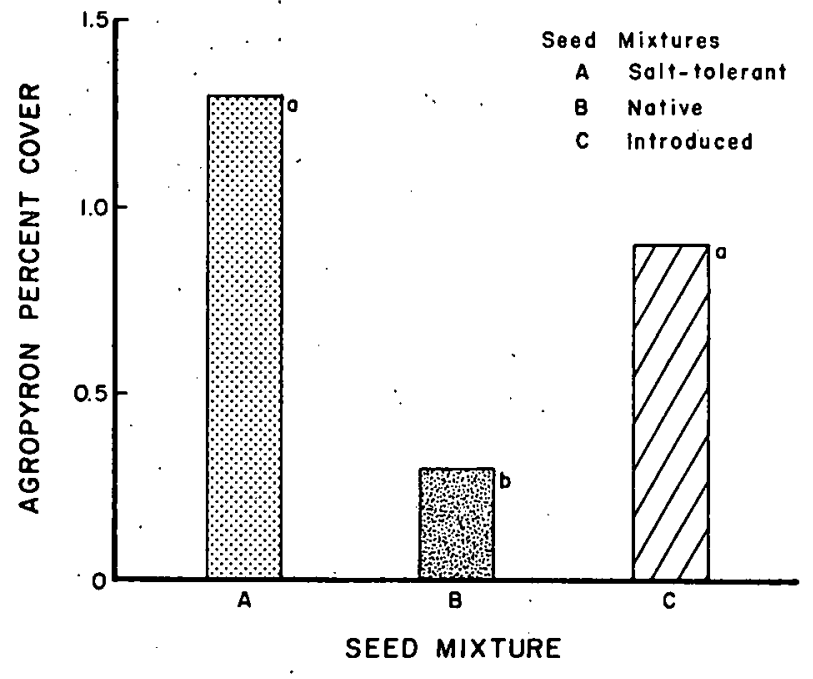

Figure 2. Wheatgrass cover by seed mixture on the Shale-to-Surface treatment. (Values followed by different letters are significantly different at $p=.10$. )

the highest production and cover values for wheatgrasses on the salt-tolerant mixture fell far below Russian thistle cover values.

Russian thistle exhibited the highest cover on subplots seeded with the introduced seed mixture and the lowest on subplots seeded with the salttolerant mixture (Figure 3 ). Apparently, the salttolerant species were able to utilize resources such as moisture and nutrients better than most species seeded in the other two mixtures and therefore excluded more Russian thistle from the area.

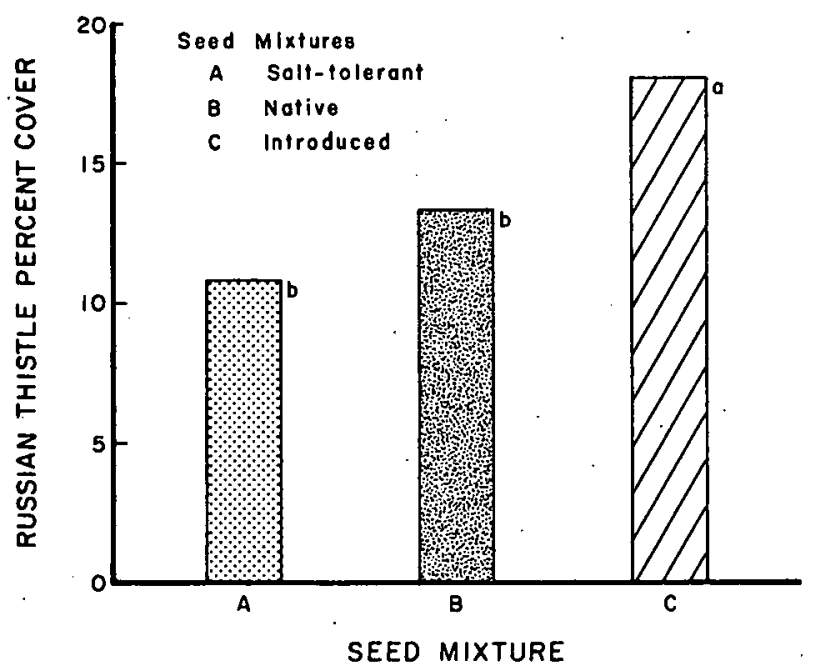

Figure 3 . Russian thistle cover by seed mixture. (Values followed by different letters are significnatly different at $p=.10)$.

\section{Effects of Fertilizer}

Fertilizer treatments affected Russian thistle growth dramatically. Cover of Russian thistle increased with increasing fertilizer (Figure 4).

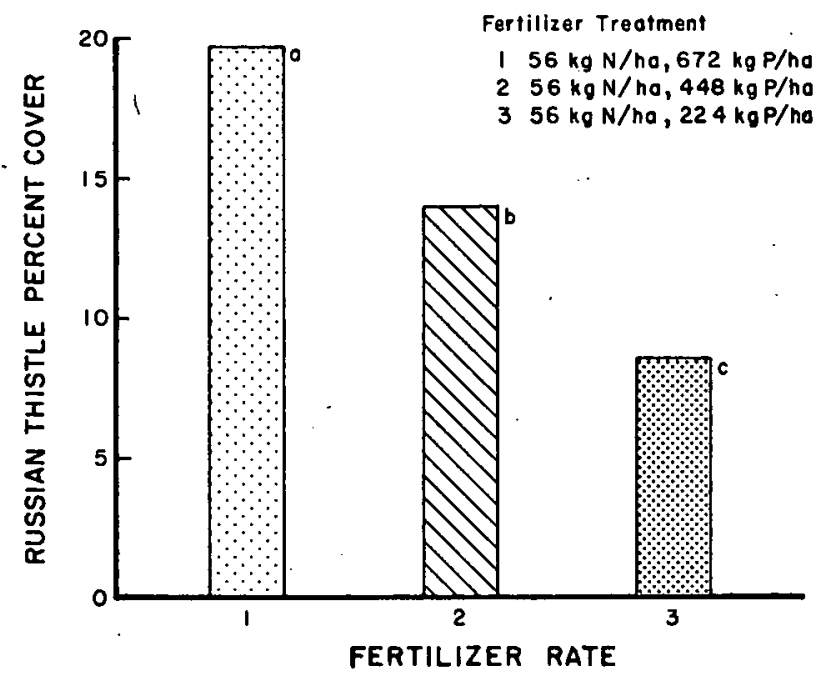

Figure 4. Russian thistle cover by fertilizer treatment. (Values followed by different letters are significantly different at $p=.10$.)

Generally, wheatgrasses showed the lowest cover on the lowest fertilizer rate, but there was no difference in cover between the two higher rates (Figure 5). It appears that something other than available phosphorus is limiting the growth of wheatgrasses once $448 \mathrm{~kg} \mathrm{P} / \mathrm{ha}$ is applied to the shale material.

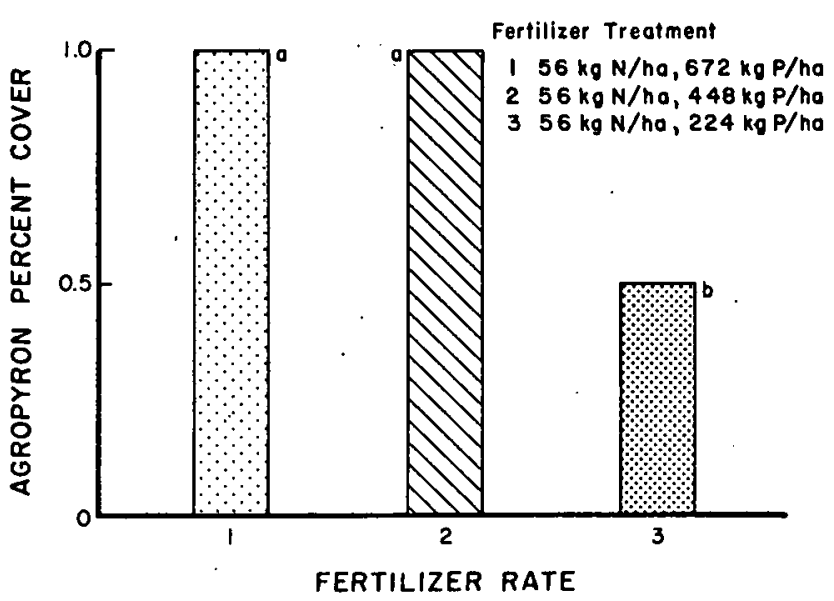

Figure 5 . Wheatgrass cover by fertilizer treatment on the Shale-to-Surface treatment. (Values followed by different letters are. significantly different at $p=.10$.) 
Conclusions:

Following two separate attempts over a fouryear period, it was not possible to establish an effective stand of vegetation directly on Paraho retorted shale with the treatments tested. The use of fertilizer, salt-tolerant species, and high rates of straw mulch on retorted shale material (which was allowed to undergo natural weathering for two years) was not adequate for successful plant establishment. It is bel ieved that high levels of soluble salts in combination with nutrient imbalances, toxic trace elements, and high surface temperatures of the retorted shale during the growing season were responsible for the fallure of plants to become established. It appears that the only feasible approach to establishing a diverse and self-sustaining plant community on Paraho retorted shale will be to cover the shale with adequate amounts of soil material. Leaching the shale to remove salts from the root zone will alter the chemistry of this, material, perhaps making it a more acceptable plant growth media. However, there is not adequate evidence at this time to support this, and there are no assurances that the shale will not resalinize with time. In addition, the problem of trace element accumulation by plant materials is still being researched and may represent a major stumbling block to establishing plants directly on retorted shale material.

\section{Retorted Shale Successional Study}

\section{Introduction}

The Retorted Shale Successional Study was inttlated in the summer of 1977 to evaluate the effects of topsoil depth over retorted shale along with capillary barriers on plant growth and succession. To evaluate these techniques, several topsoll-shale profiles were constructed to simulate conditions that may result from various retorted shale disposal plans. The dimenstons of each proflle treatment measured $23 \times 109 \mathrm{~m}$ and varied in depth from 61 to $152 \mathrm{~cm}$ depending upon the treatment. The profile configurations are:

1. Retorted shale without topsoll covering

2. $30 \mathrm{~cm}$ topsoll over retorted shale

3. $61 \mathrm{~cm}$ topsoll over retorted shale

4. $91 \mathrm{~cm}$ topsoll over retorted shale

5. $61 \mathrm{~cm}$ topsoll over. $30 \mathrm{~cm}$ rock capillary barrier over retorted shale

6. Disturbed soll check with no retorted shale

All profiles containing shale received $61 \mathrm{~cm}$ of Paraho (direct mode process) retorted shale from the Anvil Points retorting factlity near Rifle, Colorado. The lower $15 \mathrm{~cm}$ of retorted shale in each proflle was compacted to reduce soll water movement through the materfal.

Following topsotl placement the six proftles were drili seeded with three seed mixtures which consisted of diverse combinations of grasses, forbs, and shrubs. The three mixtures contained either all native, all introduced or a combination of native and introduced species (Table 3 ). Nitrogen and phosphorus were applied in the following combinations:

Treatment 1: $112 \mathrm{~kg} \mathrm{~N} / \mathrm{ha}, 56 \mathrm{~kg} \mathrm{P} / \mathrm{ha}$

Treatment 2: $\quad 56 \mathrm{~kg} \mathrm{~N} / \mathrm{ha}, 28 \mathrm{~kg} \mathrm{P} / \mathrm{ha}$

Treatment 3: no fertilizer

The study is arranged in a randomized block design with three replications. Each replication contains nine subplots which include all combinations of seed mixtures and fertilizer treatments. Each subplot has six permanently marked quadrats which have been sampled each year for density, aboveground biomass, and percent cover by species. These measurements were made on both seeded and invading species.

Diversity was estimated using Shannon-Weiner index (Shannon and Weaver 1973) and using a ratio of the relative cover of each species to the total cover of all species (Bonham 1974). Higher diversity indices indicate higher structural diversity. and possibly greater plant stand stability.

Data from the 1980 season were analyzed using multiple regression. Trends were analyzed using 1978 , 1979, and 1980 data by means of multiple regression with year as a. continuous variable. All analyses were done by species and life form (grasses, forbs, shrubs).

\section{Results and Discussion}

Results presented here are from data obtained during the 1978, 1979, and 1980 growing seasons. Interpretation of the results must be considered in light of the fact that the plant community is three years old and, therefore, still in the early stages of succession. However, significant plant responses and trends have been observed which may affect future reclamation practices used on retorted shale.

\section{Effects of Topsoll Depth Over Retorted Shale}

Topsoil coverings have moderated the detrimental effects of the retorted shale material somewhat, and differing depths of topsoll have had pronounced effects on the development of the seeded communities.

Canopy cover of seeded species increased with increasing soil depth over retorted shale (Figure 6). The greatest cover values were observed on the $61 \mathrm{~cm}$ topsoll with capillary barrier treatment with the $91 \mathrm{~cm}$ topsoll treatment having the second highest values. Production was also greatest on the capillary barrier and $91 \mathrm{~cm}$ of topsoil over retorted shale. No differences in production and cover were observed between the other two topsoil treatments $(30$ and $61 \mathrm{~cm})$ and the control (no retorted shale).

Soll pits were excavated on each of the retorted shale treatments to examine root growth and morphology in the soll and shale. Roots of most seeded spectes have filled the avallable topsoll on each panel. Roots growing in topsoil were vigorous and 
Table 3. Seeding mixtures and rates used on the Retorted Shale Successional Study..

Common Name

Scientific Name

Seeding

Rate

PLS

$(\mathrm{kg} / \mathrm{ha})$

Mixture A--Combination (native and introduced) species

1. Nordan crested wheatgrass

2. Siberian wheatgrass

3. Critana thickspike wheatgrass

4. Sodar streambank wheatgrass

5. Slender wheatgrass

6. Regar meadow brome

7. Indian ricegrass

8. Green needlegrass

9. Durar hard fescue

10. Madrid yellow sweetclover

11. Sweetvetch

12. Globemal low

13. Lewis flax

14. Arrowleaf bal samroot

15. Fourwing saltbush

16. Stansbury cliffrose

17. Winterfat

18. Green ephedra

Mixture B--Native species

1. Rosana western wheatgrass

2. Sodar streambank wheatgrass

3. Bearded bluebunch wheatgrass

4. Indian ricegrass

5. Green needlegrass

6. Durar hard fescue

7. Shermans big bluegrass

8. Alkali sacaton

9. Globemallow

10. Sweetvetch

11. Palmer penstemon

12. Stansbury cliffrose

13. Green ephedra

14. Fourwing saltbush

15. Winterfat

16. Antelope bitterbrush.

Mixture C--Introduced species

1. Nordan crested wheatgrass

2. Siberian wheatgrass

3. Jose tall wheatgrass

4. Luna pubescent wheatgrass

5. Oahe intermediate wheatgrass

6. Manchar smooth brome

7. Regar meadow brome

8. Vinal Russian wildrye

9. Ladak alfalfa

10. Madrid yellow sweetclover.

11. Lutana cicer milkvetch

12. Sainfoin

13. Bouncing bet

14. Small burnet

15. Siberian peashrub

16. Russian ol ive
Agropyron cristatum

1.12

Agropyron sibericum

1.12

Agropyron dasystachyum

Agropyron riparium

Agropyron trachycaulzom

Bromus erectus

Oryzopsis hymenoides

Stipa viridula

Festuca ovina duriuscula

Melizotus officinalis

Hedysarum boreale

Sphaeralcea munroana

Linum Lewisii

Balsamorhiza sagittata

Atriplex canescens

Cowania mexicana stansburiana

Ceratoides lanata

Ephedra viridis

1.12

1.12

1.12

1.12

1.12

1.12

0.56

0.56

1.12

0.56

0.56

1.12

1.12

1.12

1.12

1.12
Agropyron smithii

Agropyron riparium

Agropyron spication

Oryzopsis hymenoides

Stipa viriduza

Festuca ovina duriuscula

Poa ampla

Sporobolus airoides

Sphaeralcea munroana

Hedysarum boreale

Penstemon palmeri

Cowania mexicana stansburiana

Ephedra viridis

Atriplex canescens

Ceratoides Zanata

Purshia tridentata
1.12

1.12

1.12

1.12

1.12

0.56

1.12

0.56

0.56

1.12

0.56

2.24

1.12

1.12

1.12

1.12
Agropyron cristatum

Agropyron sibericum

Agropyron elongation

Agropyron trichophomom

Agropyron intermedium

Bromus inermis

Bromus erectus

Elymus junceus

Medicago sativa

Melizotus officinalis

Astragalus cicer

Onobrychis viciaefolia

Saponaria officinalis

Sanguisorba minor

Caragana arborescens

Elaeagnus angustifolia
1.12

1.12

1.12

1.12

1.12

1.12

1.12

1.12

0.56

0.56

0.56

0.56

1.12

2.24

1.12

2.24 


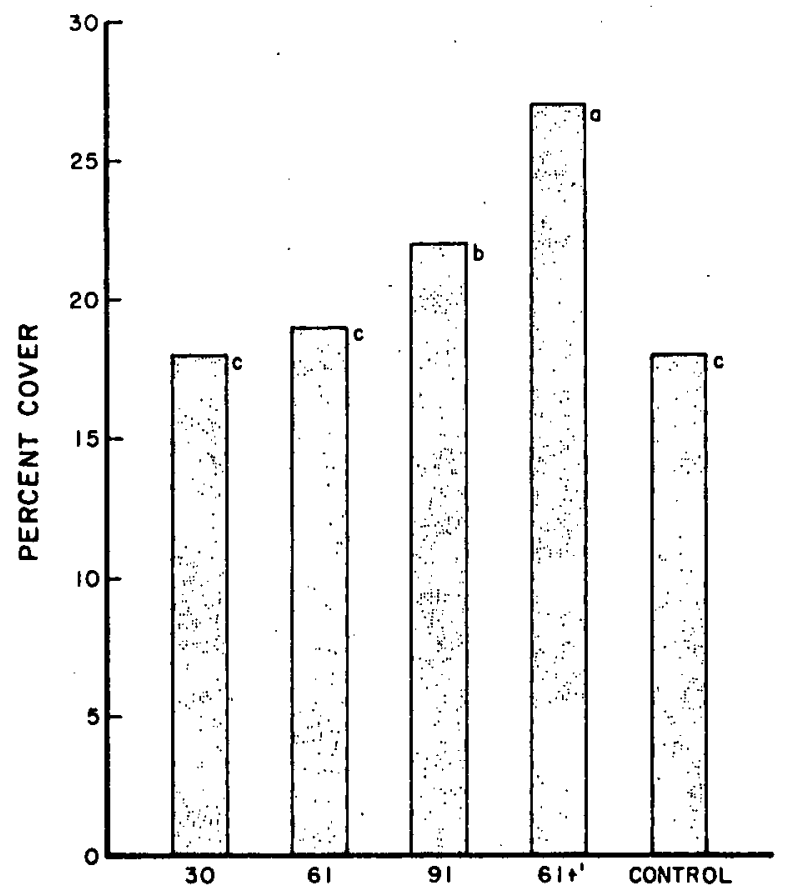

SOIL DEPTH $(\mathrm{cm})$ OVER RETORTED SHALE

$161+=61 \mathrm{~cm}$ topsotl over $30.5 \mathrm{~cm}$ rock coplliary borrier.

Figure 6. Cover of seeded species by topsoil treatment over retorted shale. Values are across all seed mixtures and fertilizer treatments. (Values followed by different letters are significantly different at $p=.10$.

showed normal, branching morphology. However, roots growing into the retorted shale material were extremely fibrous and less vigorous than in the soil. Thorup (1969) has observed this same structure on roots growing in high pH solutions and concluded that root damage was a direct effect of $\mathrm{pH}$. Ries et al. (1976) in a study of eight perennial forage spectes noted a decrease in root blomass with increasing salt concentration in coal mine spolls. This decrease was attributed to toxic or nutritional effects of the salts. Therefore, the morphology of roots in shale may be due to the high $\mathrm{pH}$ and salt content found in the retorted shale material. Roots of grasses, forbs, and shrubs growing on the shallower topsoil treatments have penetrated the shale to $13 \mathrm{~cm}$ (although most are concentrated in the top $8 \mathrm{~cm}$ ) while on the $91 \mathrm{~cm}$ topsoll treatment the only roots that have penetrated into the shale are from native shrubs. Grass and forb roots on the capillary barrier treatment have not been able to penetrate the barrier. However, shrubs such as fourwing saltbush (Atriplex canescens) and winterfat (Ceratoidea lanata) have penetrated the barrier partly because topsoll is filtering into the barrier. The downward movement of soll into the barrier is threatening its effectiveness in stopping the rise of salts from the shale matertal below; the results of this w11l probably be seen in future years as plant growth is affected.
Other factors need to be considered when assessing the quality of the plant community and its ability to survive on retorted shale disposal sites. Plants have successfully established on the $30 \mathrm{~cm}$ topsoil treatment, the shallowest topsoil covering. However, Schwab et al. (1980) noted that dichotomous plants (forbs and shrubs) growing on the shallower topsoil treatments are accumulating boron to near phytotoxic levels. They also noted that these plants are accumulating molybdenum to levels that could cause molybdenosis in herbivores grazing on the plants. Klein et al. (1980) found depressed levels of dehydrogenase activity, phosphatase activity, and nitrogen fixation potential on all topsoil treatments except the control and capillary barrier treatments. Klein suggested that a capillary barrier may be necessary for the development of a diverse and functional microbial community needed to sustain plants growing on the area.

\section{Effects of Seed Mixture}

Reclamation laws have emphasized the use of native species on disturbed lands. This has increased the importance of comparing native to introduced seed mixtures. Aboveground production values for all three seed mixtures used in this study were about equal. However, the native seed mixture exhibited slightly greater canopy cover than efther the introduced or combination mixtures due to its more decumbent growth form (Figure 7). Spectes of native grasses primarily responsible for this effect were Shermans big bluegrass (Poa ampla), Sodar streambank wheatgrass (Agropyron riparium), Rosana western wheatgrass (Agropyron smithii), and beardless bluebunch wheatgrass (Agropyron inerme). Nordan crested wheatgrass (Agropyron cristatum) and Oahe intermediate wheatgrass (Agropyron intermedium) were two introduced grasses that showed good cover $(>3.5 \%)$. The only grasses that have shown steady increases in production and cover over three years were Nordan crested wheatgrass and Shermans big bluegrass. Other grass species have either shown a peak in production and cover in 1979 with a slight decline in 1980 or have declined since 1978. These declines could be due to competition with increasers for space and nutrients, a result of litter accumulation or the adaptability of the species to the site. The reasons may become clearer as the stands develop in the future.

Seeded forbs in the combination seed mixture showed lower production in 1980 than forbs in the other two seed mixtures. Madrid yellow sweetclover (Melizotus officinalis) provided $80 \%$ of seeded forb biomass in the combination seed mixture in 1979. This contribution to seeded forb blomass decreased in 1980 to only $15 \%$ because of the blennial iffe cycle of sweetclover. Therefore, 1980 production of total seeded forbs was less in combination seed mixture plots than in plots seeded with the other two mixtures. Sweetclover was also present in the introduced seed mixture, and this mixture showed the same growth trends as the combination mixture (Figure 8). However, production of sweetclover was lower in 1978 and 1979 because of greater competition with vigorous introduced grasses. Total seeded forb production in 1980 did not decline as much in introduced seed mixture plots as compared to combination seed mixture plots because alfalfa (Medicago 


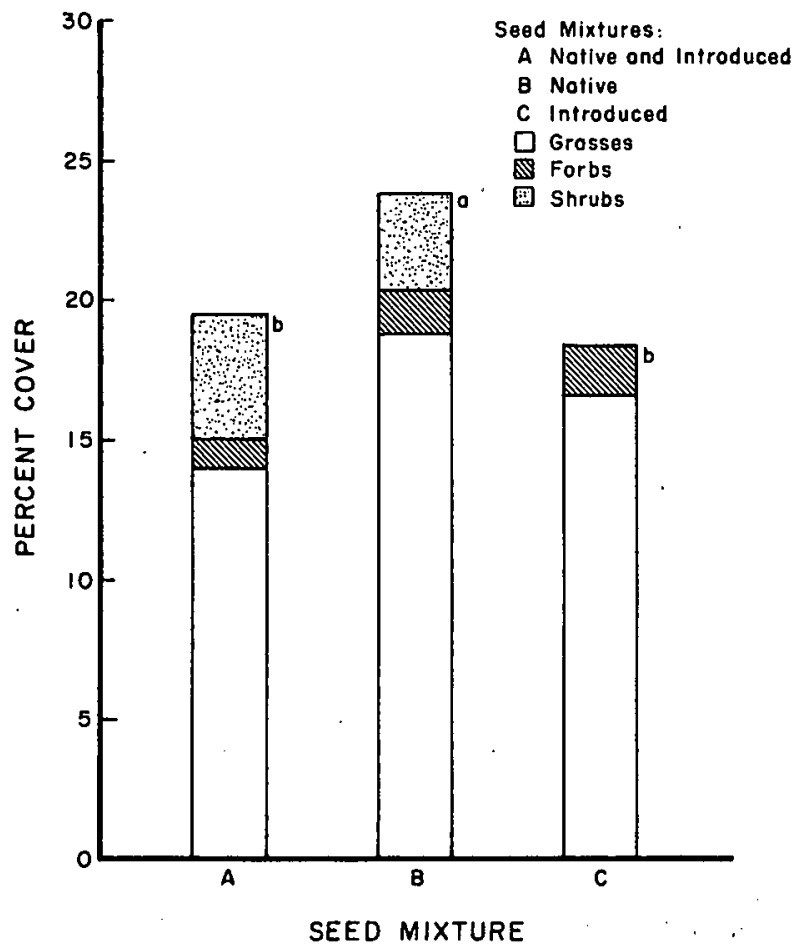

Figure 7. Cover of seeded species by seed mixture. (Values followed by different letters are significantly different at $p=.10$. )

sativa) production in 1980 increased $400 \%$ over 1979 values. Therefore, the seeded forb production decline for the introduced seed mixture was not as dramatic as the decline found in the combination seed mixture for two reasons: (1) less initial sweetclover in the introduced seed mixture due to introduced grass competition and (2) $400 \%$ increase in alfalfa production from 1979 to 1980.

Seeded shrub cover was greater in both the native and combination seed mixtures than in the introduced mixture. This is attributed to the excellent growth of winterfat and fourwing saltbush in these two mixtures: The introduced shrub species, Siberian peashrub (Caragana arborescens) and Russian olive (Eleagrous angustifolia), failed to establish from seed. This is probably because of the inability of these species to compete with grasses and forbs under the environmental conditions at the site. More research work needs to be done in selecting species and improving establishment techniques for native and introduced shrubs for reclamation work.

\section{Effects of Fertilizer}

Biomass of seeded grasses increased with increasing fertilizer rates (Figure 9). Introduced grasses exhibited the greatest response to fertilizer. Wight and Black (1978) found that grasses respond to increasing fertilization with increases in root surface area and depth. This allows the grasses to extract soil mo isture nutrients faster than other life forms and thus give the grasses a competitive advantage.

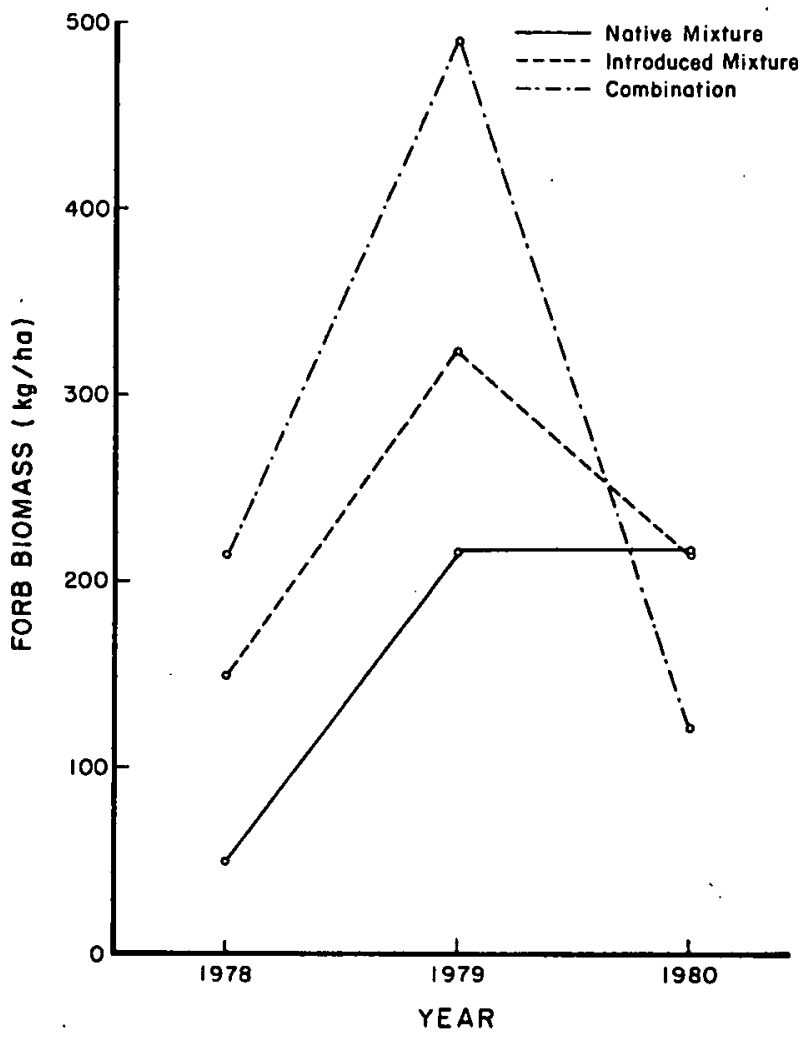

Figure 8. Three-year trends for seeded forb production by seed mixture.

Unlike grasses, seeded forbs showed decreases in production with increased fertilization (Figure (Figure 9). Almost all forbs used in this study were nitrogen-fixing legumes, and it is presumed that $\mathrm{N}$ fertilization decreased the competitive advantage these forbs generally have under low nutrient conditions. Thus, $\mathrm{N}$ and $\mathrm{P}$ fertilization increased grass growth to the detriment of forbs.

Shrubs in the combination versus native seed mixture responded differentiy to fertilizer application. In combination seed mixture plots, shrub production decreased with increasing fertilization. This can be attributed directly to increases in grass competition. However, shrubs in native seed mixture plots showed increasing production with increases in fertilizer rates (Figure 10). Perhaps native grasses do not compete with shrubs as strongly as the introduced grasses in the combination seed mixture.

\section{Diversity}

In this study diversity changed dramatically by year and treatment. Generally, diversity increased to a high in the second year of the study and then decreased in the third year. (Figure 11). However, when this effect is noted by seed mixture across years (Figure 12), it can be seen that the native and combination seed mixtures exhibit this effect more strongly than the introduced seed mixture. The introduced seed mixture showed the highest diversity of any seed mixture the first year and then 


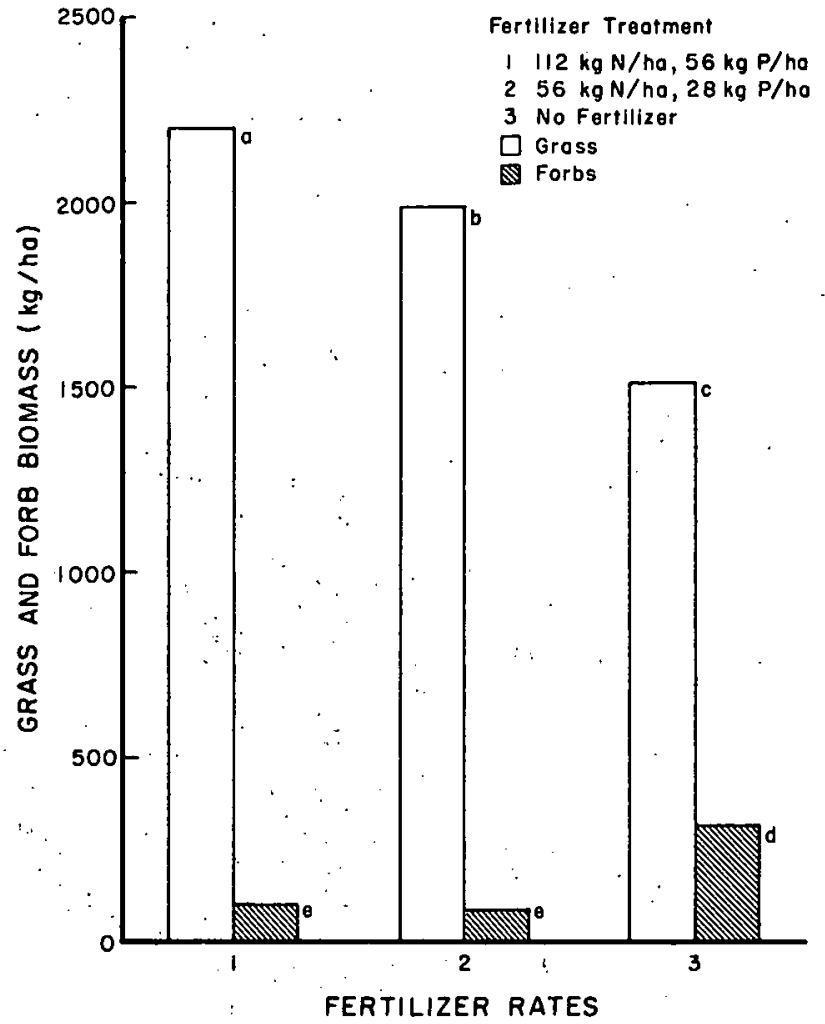

Figure 9. Aboveground production of seeded grasses and forbs in response to fertilizer treatment. Values are averages across ail seed mixtures and topsoil treatments. (Values followed by different letters are significantly different at $p=.10$.)

steadily declined. These seed mixture effects can be explained by the relative establishment times and competitiveness of native and introduced species. Introduced species establish faster and are generally more vigorous and competitive than native species. Therefore, introduced seed mixture plots are quickly dominated by crested and intermediate wheatgrasses. The native seed mixture plots may show this same effect in future years if Shermans big bluegrass continues to show the steady increases of the first three years of study. Even with these declines in diversity from 1979 to 1980 , all plots are showing comparable or greater diversity than undisturbed native vegetation.

After three years diversity is seen to decline as soil depth increases (Figure 13). Lowest diversity is found on the capillary barrier and control treatments. Apparently, highly competitive plants are being kept from completely dominating the plant community on the shallower topsoil treatments

This could be because plant roots of competitive species are reaching the retorted shale more quickly than plant roots of less competitive species. The more competitive plants may be $1 \mathrm{im-}$ ited in their growth because of inhibitory qualities of the retorted shale on plant growth in addition to the lack of available topsoil. This would then allow greater growth of more species and

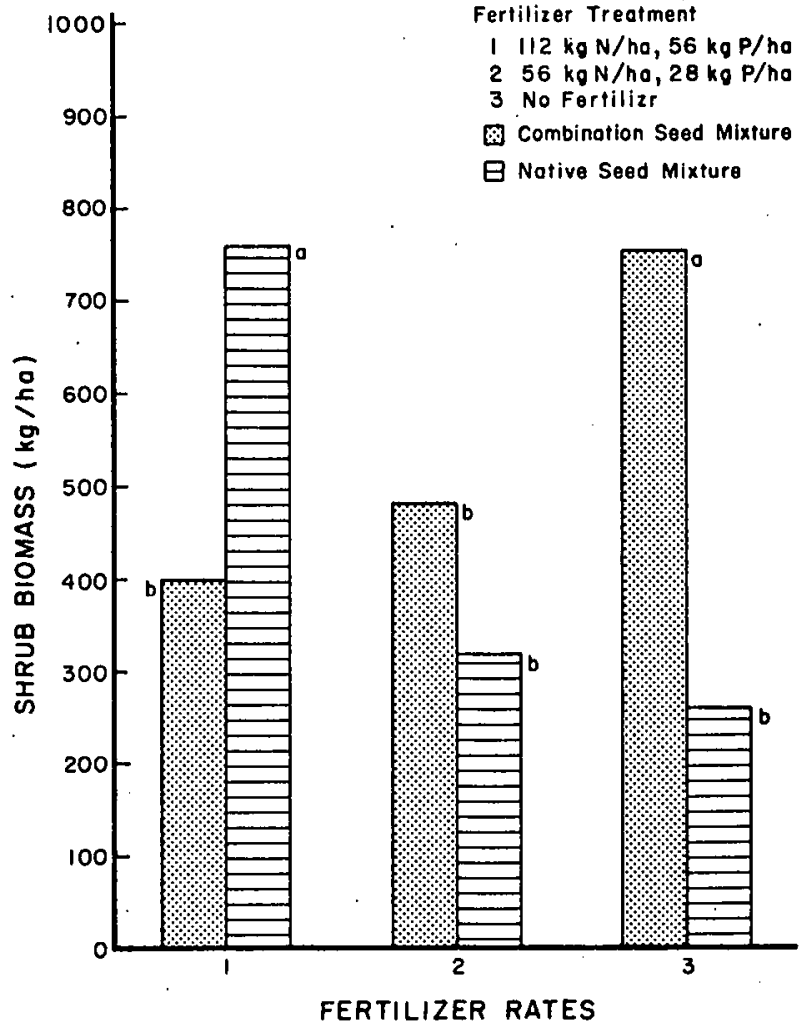

Figure 10. Aboveground production of seeded shrubs in response to fertilizer treatment. Values are averages across all topsoil trea tments. (Values followed by different letters are significantly different at $p=.10$. )

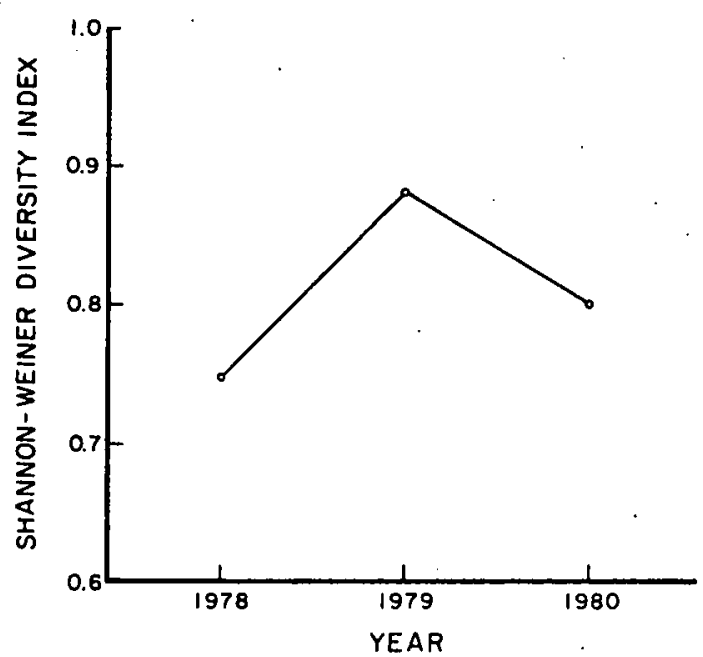

Figure 11. Diversity of a 11 seeded stands by year. (Values are averages across all soil depths; seed mixtures, and fertilizer treatments.) 


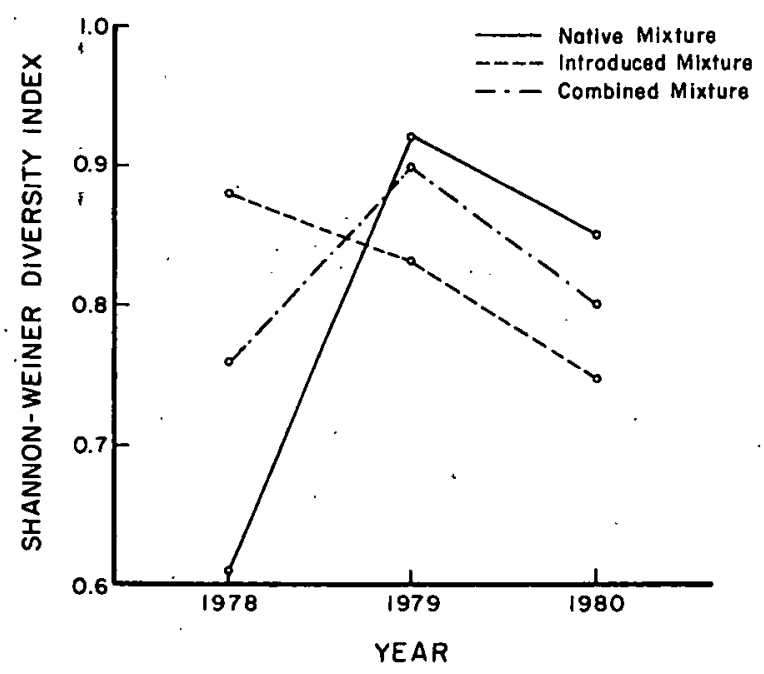

Figure 12. Diversity of seeded stands by seed mixture across years. (Values are averages across all soil depths and fertilizer treatments.)

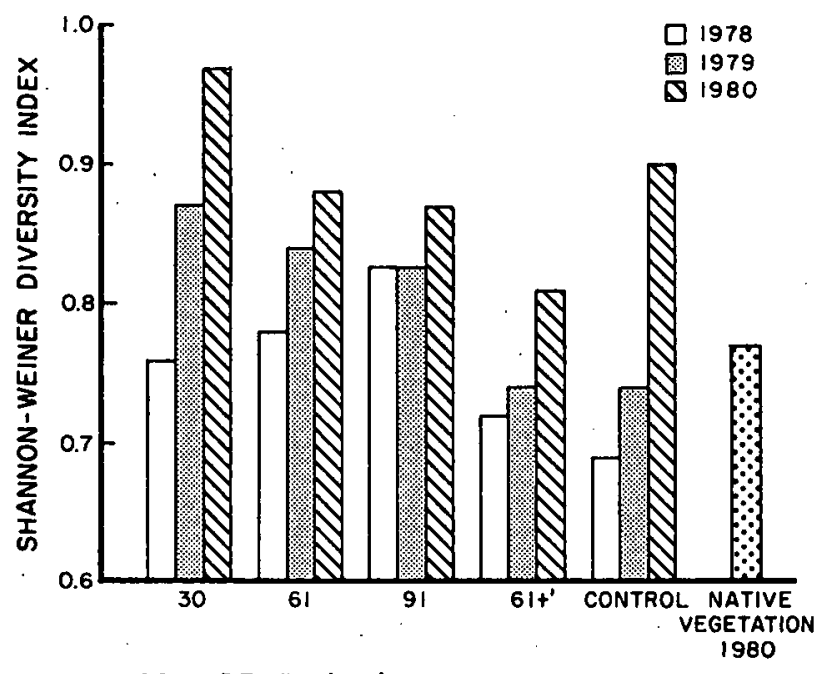

SOIL DEPTH $(\mathrm{cm})$ OVER RETORTED SHALE

$' 61+=61 \mathrm{~cm}$ topsoll over $30.5 \mathrm{~cm}$, rock capillory borrier

Figure 13. Diversity of seeded stands by soil depth over retorted shale. (Values are averages across all seed mixtures and ferfilizer treatments.)

smaller individuals of these species which would in turn increase diversity.

Increasing fertilizer rates decreased stand diversity by 1979 with the effect being more pronounced in 1980 (Figure 14): It is assumed that highly competitive plants were able to take advantage of the fertilizer and thus dominate the vegetation stand faster.with increasing fertilizer rates.

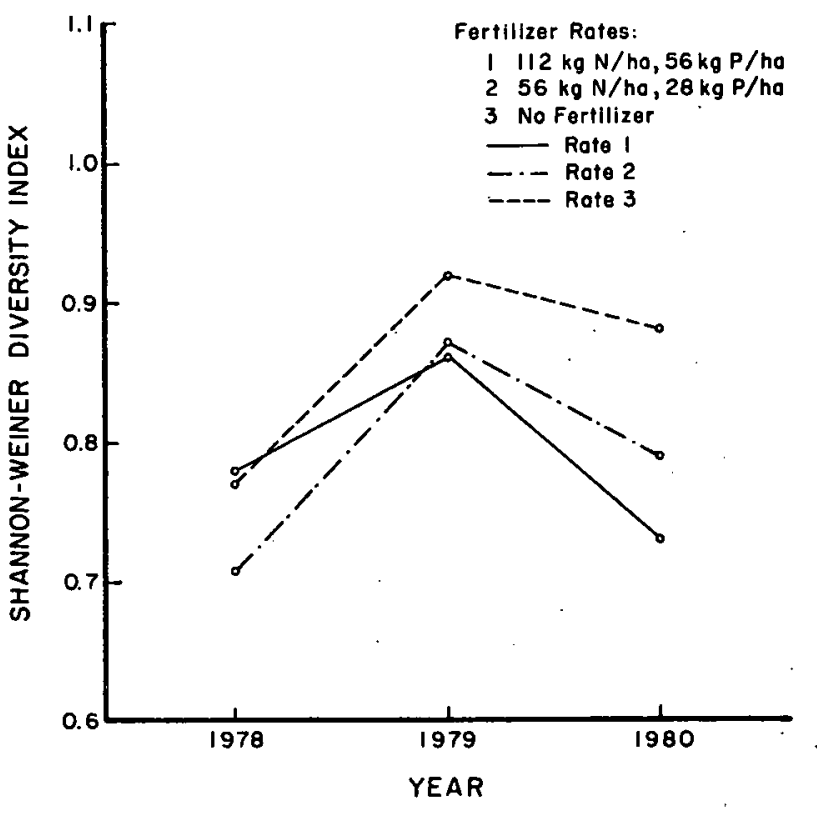

Figure 14. Diversity of seeded stands by fertilizer rates. (Values are averages across all soil depths and seed mixtures.)

Conclusions

The following conclusions are based on thirdyear data and three-year trends from the Retorted Shale Successional Study. As vegetation succession proceeds and the plant stands develop, changes in these conclusions may occur. However, some results and the conclusions drawn from them may dramaticaliy affect the disposal and subsequent reclamation of retorted shale.

Paraho retorted shale cannot be directly revegetated after three years of natural weathering without great inputs of water, fertilizer, and mulch. The best alternative to these inputs of resources and management is to cover the shale material with an adequate amount of topsoil material. For best results topsoill material should be depos:ited on the shale either to a depth of at least 9] $\mathrm{cm}$ or $61 \mathrm{~cm}$ in conjunction with a capillary barrier to allow the development of diverse and functional above- and belowground biological systems. Following topsoiling, native species should be drill seeded with a diverse array of plants that provides adequate cover by the second year. If more immediate (first-year) stabilization of topsoil is preferred, introduced species may be a better alternative. However, when introduced species are used, problems may develop as some species (e.g., crested and intermediate wheatgrass) tend to dominate and exclude other species from the stand and thus may severely reduce stand diversity. Therefore, a mixture of native and introduced species may be best to allow better diversity and rapid soil stabilization. Fertilizer applications are useful for initial stand establishment but should be at low levels (possibly below $56 \mathrm{~kg} \mathrm{~N} / \mathrm{ha}$ and $28 \mathrm{~kg} \mathrm{P} / \mathrm{ha}$ ) in order to encourage higher diversity by allowing relatively noncompetitive plants 
(such as, forbs and shrubs) to become estabiished before facing intense competition from grasses.

Annual Disturbance Plot Study

\section{Introduction}

The Annual Disturbance Study was initiated in 1976 to examine the effects of soil disturbance on natural invasion and succession. Four levels of disturbance were applied, simulating various levels of disturbance which may accompany oil shale development. The treatments were:

Treatment 1: Scrape vegetation off while leaving in place as much topsoil as possible

Treatment 2: Scrape vegetation off and rip the soil to a depth of $30 \mathrm{~cm}$

Treatment 3: Remove topsoil and subsoil to a depth of $1 \mathrm{~m}$. This topsoil and subsoil were then mixed and returned to the excavated area.

Treatment 4: Remove and stockpile the top $1 \mathrm{~m}$ of soil. Remove and stockpile an additional $1 \mathrm{~m}$ of subsoil. Then replace the soils in reverse order.

A completely randomized block design was used. Two replicates for all four disturbance treatments were established in 1976, 1977, and 1979 to determine the effects of annually fluctuating environmental factors. Ten $0.25 \mathrm{~m}^{2}$ permanent quadrats were randomly placed in each treatment plot. Density, biomass, and canopy cover by species were recorded during peak vegetation production each year following treatment and subsequent years. Data were analyzed using multiple regression techniques. Treatment effects as they were influenced by yearly environmental effects on vegetation parameters were tested.

\section{Results and Discussion}

Treatment effects explained $60 \%-80 \%$ of the total variation in the data. Significant differences between treatments were found in the density, biomass, and cover of grasses (Table 4). As soil disturbance increased, grass densities, biomass, and cover decreased as a result of natural invasion and succession. Wheatgrass (Agropyron spp.) and Indian ricegrass (Oryzopsis hymenoides) were the most important indicator species of this decreasing trend. The variation in amount of grass may be caused by a loss of seed and vegetative plant parts in the soil as disturbance increased. The quality of the topsoil also declined with increased disturbance. Reeves (1980) found a decrease in mycorrhizal infection potential (MIP) as soil disturbance increased. This decrease of MIP is positively correlated $(0.833)$ with grass densities. The higher MIP values found in the least disturbed treatments (Treatments 1 and 2) may benefit the invasion, establishment, and spread of grasses compared to the highly disturbed treatments (Treatments 3 and 4)(Table 1, Figure 15).

Tabie 4. Average density $\left(\# / \mathrm{m}^{2}\right)$, biomass ( $\left.\mathrm{kg} / \mathrm{ha}\right)$, and canopy cover (\%) of grasses on the Annual Disturbance Plots which were disturbed in 1976, 1977, and 1979. Figures are a result of natural invasion and succession.

\begin{tabular}{|c|c|c|c|c|}
\hline & \multicolumn{4}{|c|}{ Soil Disturbance Treatment } \\
\hline & 1 & 2 & 3 & 4 \\
\hline Density & 38.6 & 12.0 & 1.9 & 0.7 \\
\hline Biomass & 583 & 231 & 101 & 5.0 \\
\hline Cover & 11.2 & 1.7 & 0.8 & 0.1 \\
\hline
\end{tabular}

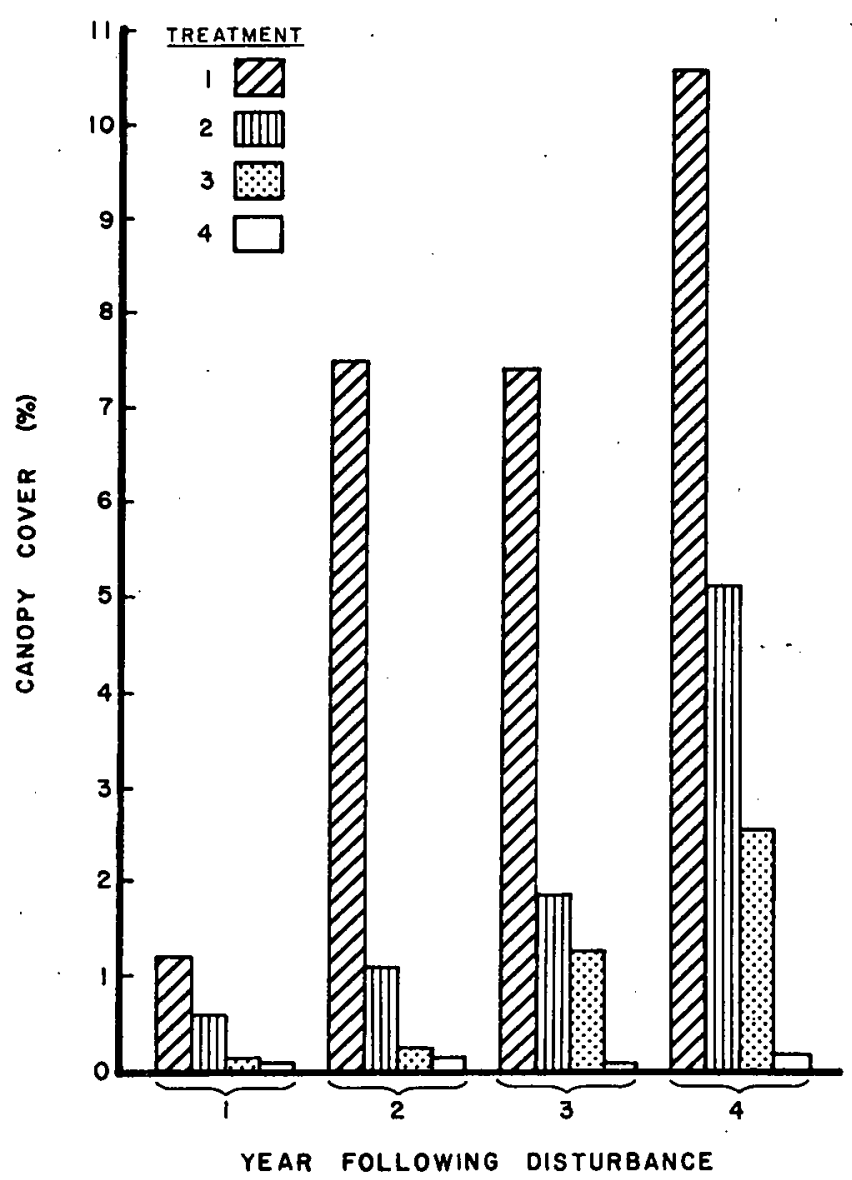

Figure 15. Canopy cover of grasses on disturbance treatments for each successive year following disturbance. 
The difference in cover between Treatments 1 and 2 indicates a greater initial loss of seed and vegetative plant parts and MIP in Treatment 2 . MIP values rose to similar levels in Treatment 2 compared to Treatment 1 the second year following disturbance (Reeves 1980). Also, seed and vegetative plant parts probably increased at similar rates in Treatments 1 and 2 . The rate of increase in grass cover between the two treatments was similar from the second through the fourth year following disturbance (Figure 15). Herbage cover in Treatments 3 and 4 (Figure 15) indicate a potential for vegetation to recover at a slower rate compared to Treatments 1 and 2 . Cover in Treatment 3 increased greatly between the third and fourth year after disturbance but not in Treatment 4 . However, MIP values were similar for Treatments 3 and 4 . Therefore, other factors besides MIP in the various degrees of disturbance accounted for some of the variation in canopy cover. One factor may be increased competition by forbs (Figure 16). Also, differences in soil quality between the treatments may explain the vegetation increases more completely.

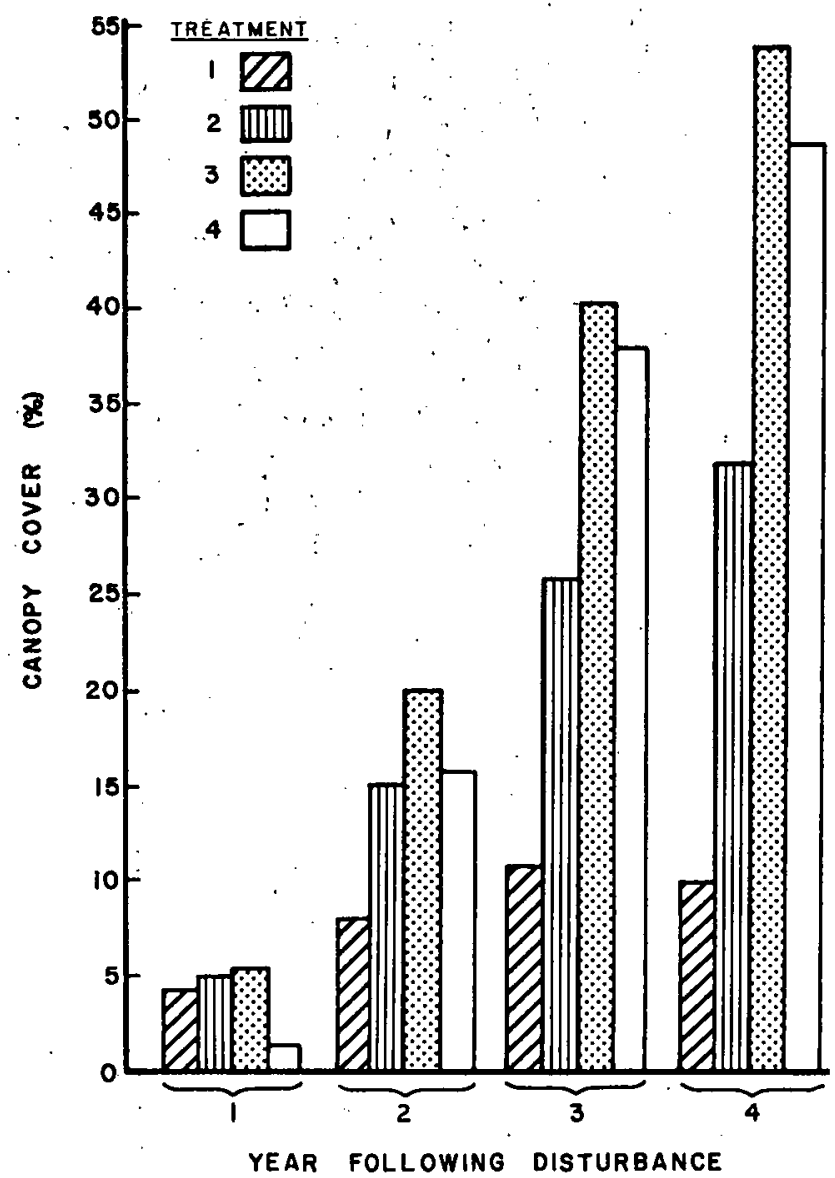

Figure 16. Canopy cover of forbs on disturbance treatments for each successive year following disturbance.
Forbs generally increased as disturbance increased (Table 5). However, Treatments 3 and 4 were not significantly different. The major forb species was Russian thistle which is an annual and may be expected to invade according to degree of disturbance and absence of perennial plants. It comprised over $80 \%$ of the forbs. It does not require mycorrhizal fungi to grow, and therefore has a competitive advantage over other forbs and grasses that are associated with MIP. Scarlet globemallow (Sphaeralcea coccinea) and phlox (Phlox muscoides) were perennial forbs found as natural invaders in most plots. They decreased, however, as disturbance increased, thus indicating that they may require mycorrhizal fungi and a seed or rhizome source to revegetate disturbed areas rapidly. Russian thistle invasion in Treatment 4 was largely a result of seed dispersed from surrounding areas while invasion in Treatment 3 may be the result of seed dispersed from surrounding areas as well as seed present in the portions of the topsoil that surfaced in the mixing procedure. Also, soil fertility and water holding capacity may be superior in Treatment 3 compared to Treatment 4. Forb densities were believed to be lower in Treatments 1 and 2 compared to Treatments 3 and 4 as a result of competition with the perennial grasses for moisture.

Table 5. Average density $\left(\# / \mathrm{m}^{2}\right)$, biomass ( $\left.\mathrm{kg} / \mathrm{ha}\right)$, and canopy cover (\%) over time of forbs on the Annual Disturbance Plots which were disturbed in 1976, 1977, and 1979. Figures are a result of natural invasion and succession.

\begin{tabular}{|c|c|c|c|c|}
\hline & \multicolumn{4}{|c|}{ Soil Disturbance Treatment } \\
\hline & 1 & 2 & 3 & 4 \\
\hline Density & 110.0 & 218.4 & 119.8 & 216.3 \\
\hline Biomass & 832 & 1725 & 2616 & 2912 \\
\hline Cover & 7.7 & 17.5 & 26.3 & 22.5 \\
\hline
\end{tabular}

Shrubs have not successfully invaded and reestablished in any of the disturbance treatments. Treatment 1 had consistently higher densities of shrubs than the other treatments. However, the densities are still extremely low compared to native, undisturbed areas. The poor establishment success is believed to be due to a combination of insufficient seed and other vegetative organ sources (especially in the more disturbed areas), lowered MIP in the highly disturbed treatments, and poor microenvironments for seedling establishment.

Yearly environmental fluctuations apparently affect the initial emergence of grasses more than they affect previously established grasses. There is a difference in the biomass of grasses between 1977 and 1979 disturbed plots in the first year following disturbance (Table 6). Differences between 1977 plots and 1979 plots were a result of precipitation differences in 1977 and 1979. Precipitation was greater in the winter of 1979 compared to the precipitation in 1977. This resulted in better moisture and therefore better grass 
establishment occurred in the 1979 plots compared to the 1977 plots. The winter of 1976 also provided better moisture for the spring of $1977 \mathrm{com}-$ pared to 1978 spring moisture. Average grass densities on plots disturbed in 1976 were 7.8 plants/ $\mathrm{m}^{2}$ on the plots disturbed in 1977 . Therefore, grass establishment was better on 1976 plots compared to 1977 plots. However, differences in grass biomass between 1976 and 1977 plots were negligible by the third year after disturbance (Table 6). Therefore, once perennial grasses become established, they rapidly increase in size and then tend to maintain that size.

Table 6. Average grass biomass $(\mathrm{kg} / \mathrm{ha})$ for all treatments on soil disturbed plots by yearly sample.

\begin{tabular}{|c|c|c|c|c|c|c|}
\hline \multirow{2}{*}{$\begin{array}{l}\text { Number of } \\
\text { Years After } \\
\text { Disturbance }\end{array}$} & \multicolumn{2}{|c|}{1976 Disturbance } & \multicolumn{2}{|c|}{1977 Disturbance } & \multicolumn{2}{|c|}{1979 Disturbance } \\
\hline & $\begin{array}{l}\text { Year } \\
\text { Sampled }\end{array}$ & Biomass & $\begin{array}{c}\text { Year } \\
\text { Sampled }\end{array}$ & Biomass & $\begin{array}{c}\text { Year } \\
\text { Sampled }\end{array}$ & Biomass \\
\hline 1 & 1977 & $\ldots+t$ & 1978 & 43 & 1980 & 124 \\
\hline 2 & 1978 & 176 & 1979 & 114 & " & \\
\hline 3 & 1979 & 322 & 1980 & 317 & & \\
\hline 4 & 1980 & 512 & . & & & \\
\hline
\end{tabular}

tBiomass not recorded.

Forbs varied from year to year regardless of the number of years following disturbance. The majority of forbs present were annuals. The establishment of these annuals is dependent on soil moisture during germination. Therefore, changes will occur annually. Forb biomass on 1976 plots increased nine-fold by 1979 but decreased in 1980 due to a reduction in soil moisture (Table 7). A similar decrease was seen on the plots disturbed in 1977 for cover in 1979 and 1980.

Table 7. Average forb biomass $(\mathrm{kg} / \mathrm{ha})$ for all treatments by yearly sample on soil disturbed plots.

\begin{tabular}{|c|c|c|c|c|c|c|}
\hline \multirow{2}{*}{$\begin{array}{l}\text { Number of } \\
\text { Years Af ter } \\
\text { Disturbance }\end{array}$} & \multicolumn{2}{|c|}{1976 Disturbance } & \multicolumn{2}{|c|}{1977 Disturbance } & \multicolumn{2}{|c|}{1979 Disturbance } \\
\hline & $\begin{array}{c}\text { Year } \\
\text { Sampled }\end{array}$ & Blomass & $\begin{array}{c}\text { Year } \\
\text { Sampled }\end{array}$ & Biomass & $\begin{array}{l}\text { Year } \\
\text { Sampled }\end{array}$ & Biomass \\
\hline 1 & 1977 & $---t$ & 1978 & 17.0 & 1980 & 69.3 \\
\hline 2 & 1978 & 33.9 & 1979 & 448.1 & & \\
\hline 3 & 1979 & $297.6^{\circ}$ & 1980 & 362.3 & . & \\
\hline 4 & 1980 & 189.1 & & & & '. \\
\hline
\end{tabular}

tBlonass not recorded.

It is common knowledge that established perennial grasses have a more developed root system and more stored carbohydrates, compared to seedlings and annual forbs, to withstand drought stress. Therefore, fluctuations in grasses are not as great as seen with annual forbs. Between $18 \%$ and $70 \%$ of the variation in forb density, biomass, and canopy cover is explained by yearly environmental fluctua- tions. The success of germination and seedling survival directly affects density, biomass, and canopy cover on plots variously disturbed from time to time.

\section{Conclusions}

1. Minimized soil disturbance maintains higher levels of MIP and seed and rhizome sources.

2. Mixing topsoil and subsoil during mining operations will reduce soil fertility and cover indigenous seed sources too deeply.

3. Natural invasion and succession of perennial plants may be much too slow for appropriate soil stabilization. Artificial seeding will accelerate the rate of reclamation.

4. Year of disturbance will affect natural revegetation because of climatic variation from year to year. If invasion and establishment is favorable within the first year after disturbance, the grass component tends to close the community rather rapidly.

\section{Invasion as Related to Revegetation Practices} on Surface Disturbed Solls

\section{Introduction}

The Successional Study on Surface Disturbed Soil was established in June of 1976 to determine the effects and interactions of seed mixture, fertilizer, and mulch as they relate to artificial plant establishment and subsequent community succession on shallowly disturbed soil. The need for studying the effects of invasion on plant community development on disturbed lands became apparent when it was noted that the seeded plant communities represented more than simple interactions among seed mixture, mulch, and fertilizer.

Invasion affects the seeded species in terms of introducing another competitive factor in the survival scheme of seeded plants. The occurrence of invading species in the plant community increases the competition for resources and makes them less available to seeded species. In the absence of invasion, the seeded species are only in competition with the environment and their own progeny. The use of proper seed mixtures and seeding rates can reduce competition among the seeded species and reduce invasion of undesirable species. The objective of an ideal seed mixture is to minimize competition within the mixture, while utilizing available soil moisture, nutrients, and incoming radiation to result in a desirable level of biomass production and sustained diversity.

An understanding of invasion as it relates to a seeded plant community is an important criteria for seed mixture selection. After three years, this study has shown, for example, that cheatgrass (Bromus tectorion) is significantly $(p=.05)$ more prevalent in seed mixtures of native species, especially during early community development, as compared with seed mixtures of introduced species. These results would seem to indicate that a proposed 
reclamation site having a high cheatgrass invasion potential might best be planted with introduced species or a native-introduced species mixture rather than just native species. However, in the long term the seeded native species may be more permanent and in time close the community while introduced species may allow intermittent invasion of species resulting from periodic stresses that reduce the stand of the seeded introduced species.

Site preparation for this study consisted of scraping off the existing vegetation and ripping the soil to a depth of $30 \mathrm{~cm}$ to simulate minor disturbances that may result from such activities as roads, construction sites, utility corridors, etc. The site was then seeded with one of six seed mixtures ranging from a simple grass mixture to a complex grass-forb-shrub mixture including both native and introduced species (Table 8 ). Three levels of nitrogen and phosphorus fertilizer were used and applied at the following rates: $112 \mathrm{~kg} \mathrm{~N} / \mathrm{ha}$ and $56 \mathrm{~kg} \mathrm{P} / \mathrm{ha}, 56 \mathrm{~kg} \mathrm{~N} / \mathrm{ha}$ and $28 \mathrm{~kg}$ $P / h a$, and a control which had no fertilizer applied. The phosphorus was applied prior to seeding, and nitrogen application occurred after the first growing season in an attempt to reduce competition from annual invading species during emergence of the seedlings. Wood fiber hydromulch was applied at a rate of $2.2 \mathrm{MT} / \mathrm{ha}$ following seeding in the fall of 1976 and was applied only to the subplots lying on the perimeter of the site, due to the mechanical limitations of the hydromulcher.

The study is a split-split-block design consisting of three replications and a total of 108 subplots (Figure 17). The subplots measured $9 \times 18 \mathrm{~m}$ and covered an area of 2.5 ha. A total of ten $0.25 \mathrm{~m}^{2}$ quadrats were randomly placed within each subplot. Biomass, density, and percent canopy cover by species were measured within the quadrats. The biomass estimate is the predominant parameter discussed in this report because it appears to provide the most consistent information per individual measurement.

In 1980 a decision was made to sample the seeded plots once every three to five years to determine subsequent succession. This was based upon the observation that the seeded communities had become relatively stable and year to year changes would be minimal compared to the first three growing seasons. As a result of this decision, sampling for 1980 was 1 imited to invading species and was done using a systematic sampling method. This method treated the entire subplot as a quadrat, and every invading plant was measured for biomass, density, and percent canopy cover. These data were then statistically transformed so that trends could be observed across years.

Field observations in conjunction with statistical analysis indicated that existing plant communities are not only a function of initial reclamation treatments but also a function of several environmental factors. For the purposes of this study, invading plant communities were assumed to be primarily a function of seed mixture, fertilizer, mulch, soil moisture, and time. The inclusion of time as a contributing factor makes it possible to employ trend analysis in the statistical treatment of this data.

\section{Results and Discussion}

The scarcity of information regarding invasion on reclaimed lands does not allow for a reaffirmation of many of the findings of this study. The information as presented may be reflecting the initial stages, long-term trends, or only significant short-term findings. However, the following results are based on trends derived from data collected over the past three years. Three years is a relatively brief period of time in terms of a successional study, but the seeded vegetation is well established and the presence of invading species has been shown to have a significant effect upon the seeded communities (Cook and Redente 1980).

The discussion of invasion has been limited to a select group of invading species (Table 9). These species are believed to be representative of the invading life forms found on the study site. Cheatgrass is representative of invading annual grasses because it comprises the major portion of invading grass species on the site. Big sagebrush (Artemisia tridentata) is of interest because of its presence as a dominant component of the adjacent undisturbed vegetation and is therefore likely to be an important invader. Scarlet globemallow is a perennial forb, and its reproductive characteristics and capacity for growth on newly disturbed areas are rather high.

In tracing invasion over the entire growing season, a comparison of aboveground biomass with density provides an estimate of plant size as related to numbers of individual plants. For example, similar biomass measurements between years, with an increase in density, indicates the establishment of many new seedlings for that season.

Trend analysis across three successive growing seasons for three years indicates an increase in density for all invading species sampled, with the exception of Chenopodizm spp. In 1979 these species exhibited a tremendous flush of growth as opposed to a step-wise increase shown by the other invading species (Figure 18). Also in 1979 the growth response of Chenopodizm spp. appeared to be correlated with the increased amount of rainfall for that year. Data analysis for 1980 (Figures 18 and 19) shows a significant $(p=.05)$ decrease in the density and biomass of Chenopodium spp. The data gathered in 1981 may indicate whether or not this decline is temporary. The response by these species may be a case of recurrent invasion as described by Clements and Weaver (1938). They discussed the invasion of newly deposited flood plain soil and silt in terms of invasion, removal, and reinvasion. Similarly, the Chenopodizon spp. were absent during the dry season of 1978, present in abundance during the high moisture season of 1979, and absent again in 1980 when available moisture was low. The contrast between the response exhibited by Chenopodium spp. and other invading species may indicate a higher moisture requirement by Chenopodium Spp.

Tumbling saltbush (Atriplex argentea) is an annual forb of the Chenopodiaceae family and apparently exhibited a similar, but not as dramatic, response to increased available soil moisture as did the Chenopodium spp. Seedling density for 1980 increased $74 \%$ over 1979 . This perhaps is a result 
Table 8. Mixtures seeded during November 1976 on the Surface Disturbed Successional Study Area.

Common Name

Scientific Name

Seeding

Rate

(kg/ha

Mixture A--Native grass mixture

1. Bearded bluebunch wheatgrass

2. Rosana western wheatgrass

3. Green needl egrass

4. Indian ricegrass

5. Sodar streambank wheatgrass

Agropyron spicatum

Agropyron smithii

3.36

Stipa vimidula

4.48

Oryzopsis hymenoides

3.36

Agropyron riparizom

2.24

3.36

Mixture B--Introduced grass mixture

1. Nordan crested wheatgrass

2. Luna pubescent wheatgrass

3. Vinal Russian wildrye

4. Oahe intermediate wheatgrass

Mixture C--Native grass-forb mixture

i. Critana thickspike wheatgrass

2. Green needlegrass

3. Bearded bluebunch wheatgrass

4. Indian ricegrass

5. Sodar streambank wheatgrass

6. Sweetvetch

7. Emeraid crownvetch

8. Lewis flax

9. Palmer penstemon
Agropyron cristation

Agropyron trichophorum

4.48

Elymus junceus

Agropyron intermedium
Agropyron dasystachyum

Stipa viridula

Agropyron spicatum

Oryzopsis hymenoides

Agropyron riparium

Hedysarnon boreale

Coronizla varia

Linuon lewisii

Penstemon palmeri
3.36

2.24

2.24

1.12

2.24

1.12

1.12

1.12

1.12

Mixture D--Introduced grass-forb mixture

i. Vinal Russian wi ldrye

2. Nordan crested wheatgrass

3. Luna pubescent wheatgrass

4. Ladak alfalfa

5. Bouncing bet

6. Small burnet

7. Lutana cicer milkvetch
Elymus junceus

Agropyron cristation

Agropyron trichophorum

Medicago sativa

Saponaria officinalis

Sanguisorba minor

Astragalus cicer
3.36

3.36

3.36

1.12

1.12

1.12

2.24

Mixture E--Native grass-forb-shrub mixture

1. Indian ricegrass

Oryzopsis hymenoides

2.24

Agropyron spicatum

2.24

Agropyron smithii

4.48

3. Rosana western wheatgrass:

4. Emeraid crownvetch

Coronitila varia

Hedysarum boreale

Cowania mexicana stansbumiana $\quad 1.12$

Ephedra viridis

Atriplex canescens

1.12

7. Green ephedra.

8. Fourwing saltbush

Ceratoides lanata

2.24

1.12

Mixture F--Native and introduced grass-forb-shrub mixture

1. Green needlegrass

2. Bearded bluebunch wheatgrass

3. Nordan crested wheatgrass

4. Luna pubescent wheatgrass .

5. Lutana cicer milkvetch

6. Sweetvetch

7. Stansbury cl iffrose

8. Green ephedra ::

9. Winterfat
Stipa viridula

Agropyron spicatum

Agropyron cristatum

Agropyron trichophorum

Astragalus cicer

Hedysarum boreale

Cowania mexicana stansbumiana

Ephedra viridis

Cèratoides Zanata 


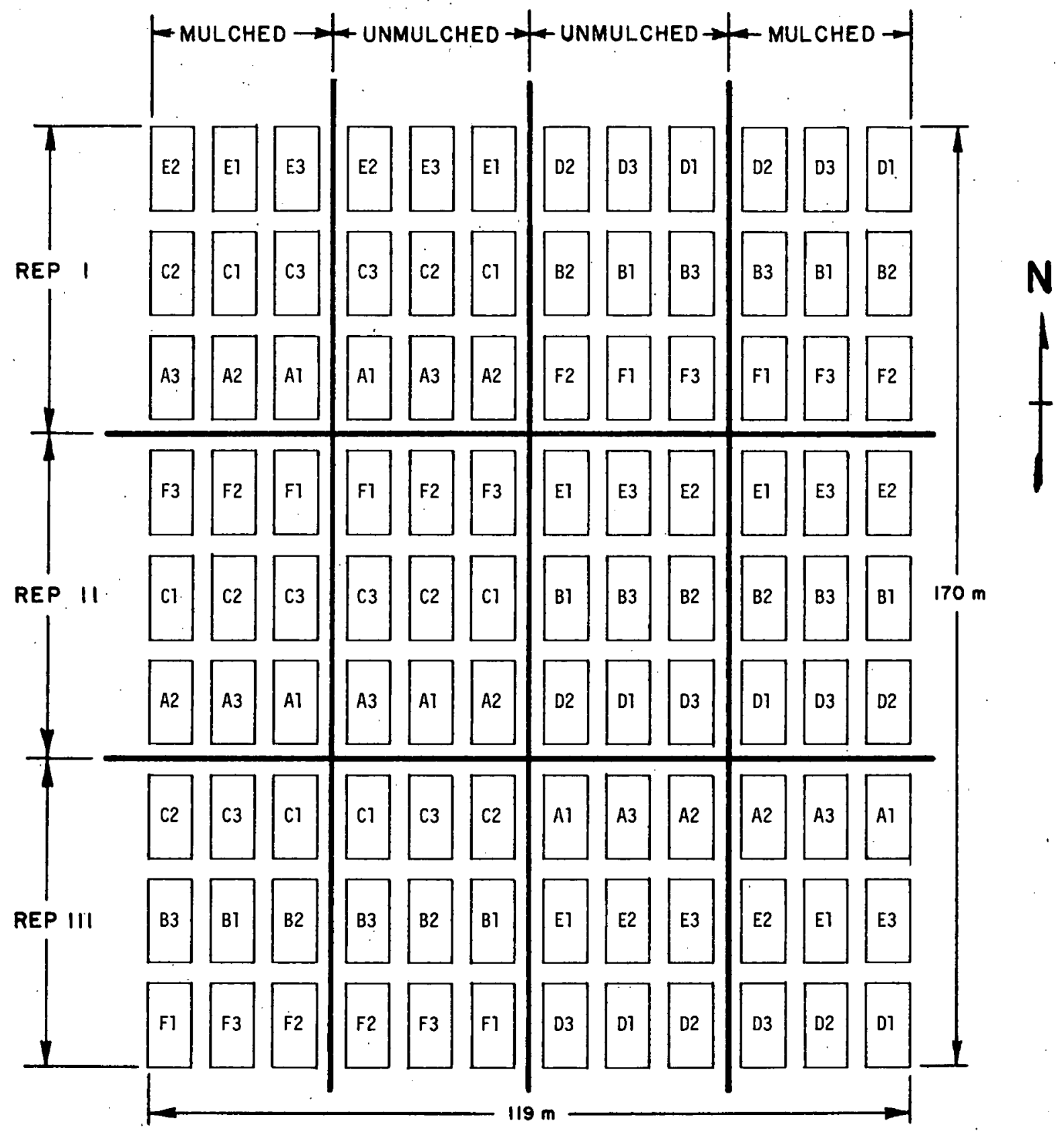

MULCH

Hydro mulch

Control (unmulched)

FERTILIZER

$1=112 \mathrm{~kg} \mathrm{~N}, 56 \mathrm{~kg} \mathrm{P}$ per hectare

$2=56 \mathrm{~kg} \mathrm{~N}, 28 \mathrm{~kg} \mathrm{P}$ per hectare

$3=$ Control $(0 \mathrm{~kg} \mathrm{~N}, 0 \mathrm{~kg} P$ per hectare $)$

\section{SPECIES SEEDED}

$A=$ Native grass mixture

$B=$ Introduced grass mixture

$C=$ Native grass-forb mixture

$D=$ Introduced grass-forb mixture

$E$ = Native grass-forb-shrub mixture

$F=$ Native and introduced grass-forb-shrub mixture

Figure 17. Experimental design for the Successional Study on Surface Disturbed Soil. 
Table 9. Invading species of interest.

\begin{tabular}{ll}
\hline \multicolumn{1}{c}{ Common Name } & \multicolumn{1}{c}{ Scientific Name } \\
\hline Grasses & \\
\hline Cheatgrass & Bromus tectomom \\
$\frac{\text { Forbs }}{\text { Tumbling saltbush }}$ & \\
Chenopods & Atriplex argentea \\
Russian thistle & Chenopodizm spp. \\
Scarlet globemallow & Salsola iberica \\
& Sphaeralcea cocinea \\
Shrubs & \\
Big sagebrush & \\
Rabbitbrush & \\
Broom snakeweed & Artemisia tridentata \\
Greasewood & Chrysothamus spp. \\
& Gutierrezia sarothrae \\
& Sarcobatus vermiculatus \\
\hline
\end{tabular}

of the presence of an abundant seed source produced from the large, mature population from the previous year. However, individual plants produced less biomass in 1980 as a result of less available soil moisture (Figures 18 and 19). The presence of sodium in the soil is a positive factor contributing to the growth of tumbling saltbush. This species was found only on areas having a rather high degree of 'sodium (SAR levels 5.8-12.9), relative to the other subplots in the study. These areas of relatively high sodium concentration were not favorable for the growth of seeded species and resulted in large patches relatively free from seeded vegetation. Therefore, competition from seeded species was not a significant factor in the establishment of tumbling saltbush.

Russian. thistle showed a significant $(p=.05)$ increase in density and biomass from 1978 and 1979 to 1980. The original increase resulted in an increase of seedlings which appears in response to higher precipitation in 1979 . Higher seed production from mature plants of the 1979 growing season provided a source of new seedlings for sustaining the density level which appeared in the 1980 growing season. Biomass in 1980 returned to 1978 levels due to lower moisture. At the time of sampling (1980) many of the seedlings were beginning to desiccate.

Scarlet globemallow exhibited a fluctuation in biomass over the past three years, with a significant increase in density from year to year. The increase in density can be attributed to the vegetative reproductive characteristics illustrated by this plant. Rather than increasing the biomass of the parent plant, carbohydrates are being distributed to the tillers. This redistribution of carbohydrates maintains the biomass of the parent plant, while fostering growth of new plants originating from crown tiliers. Scarlet globemal low is a perennial forb, and subsequent growing seasons will determine the ability of these new plants to become established mature plants (Figures 18 and 19).

The trends derived from this data can be used in predicting future trends of invasion on this site. The forbs Chenopodium spp. and Russian

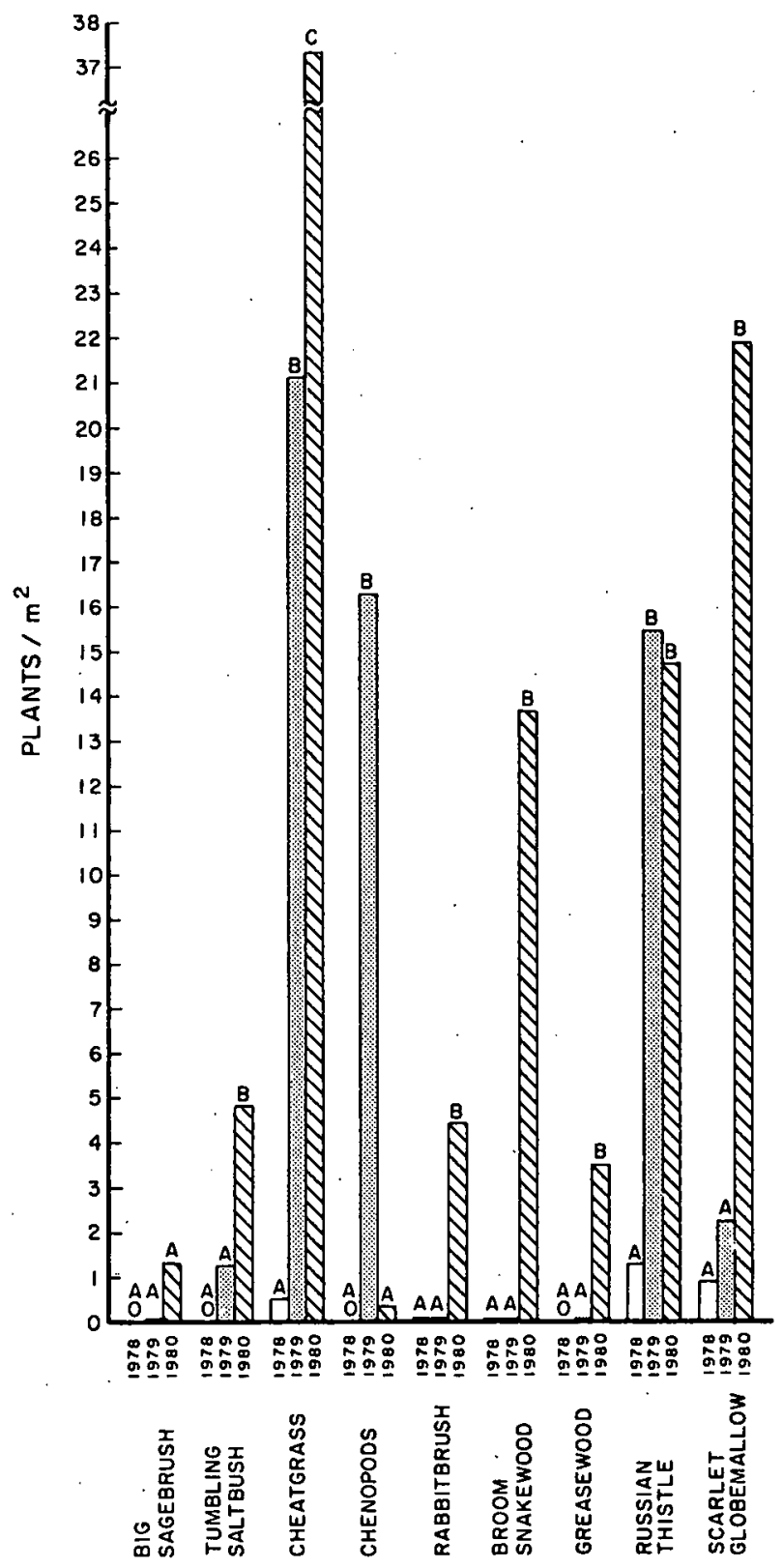

Figure 18. Density of selected invading species for 1978, 1979, and 1980 on the Shallowly Disturbed Successional Study. (Values followed by the same letter are not significant at the .05 level.

thistle appear to be reacting as recurrent invaders and will probably continue to fluctuate in response to available soil moisture. Scarlet globemallow has established itseif across all seed mixtures but may continue to increase at a slower rate due to its perennial nature and spatial limitations. This plant will most likely be reproducing both vegetatively and from seed production. The presence of Russian thistle will be maintained and show an increase in seedling density across all seed mixtures. In subsequent growing seasons the large, mature 


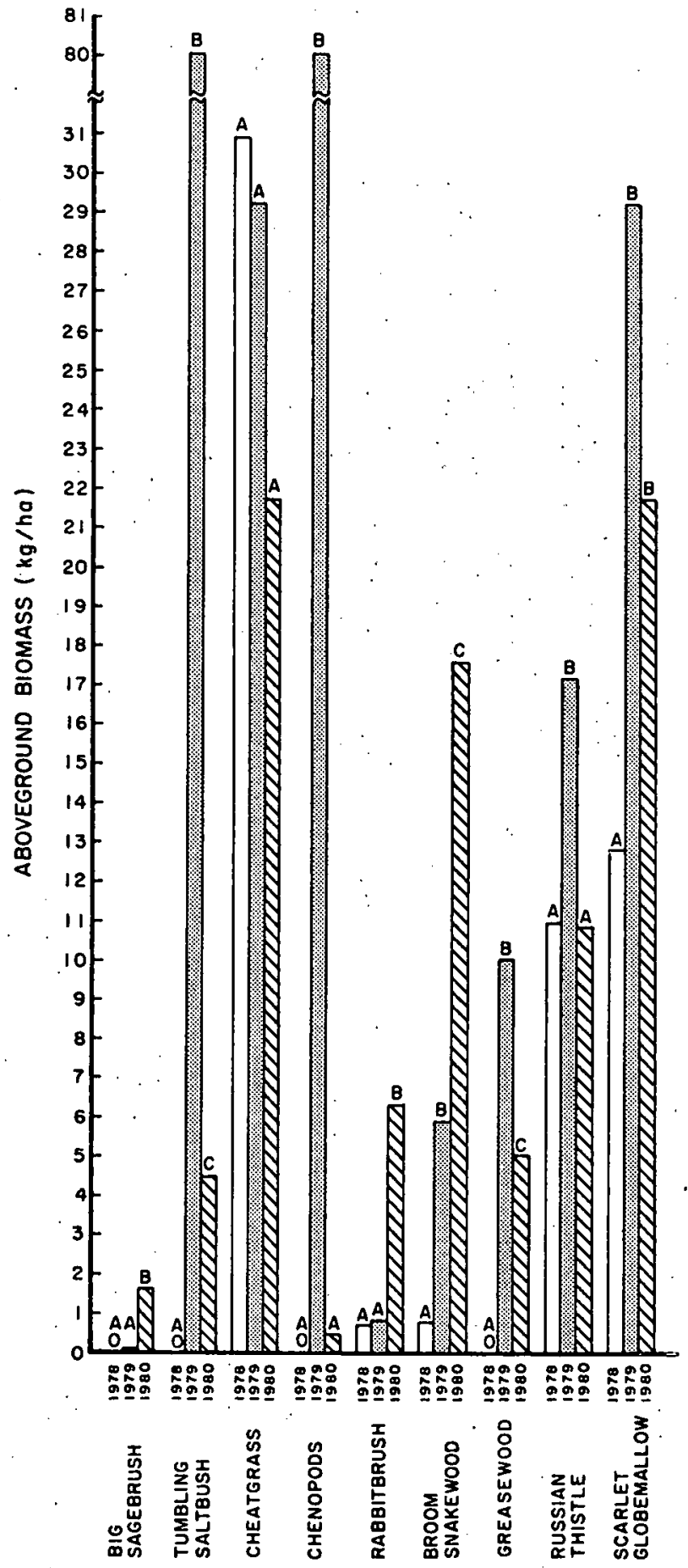

Figure 19. Biomass of selected invading species for 1978, 1979, and 1980 on the Shallowly Disturbed Successional Study. (Values followed by the same letter are not significant at the .05 level.)

plants will probably be less frequent due to spatial limitations imposed by the regeneration of the seeded species on the nonsaline soils. Seedlings, however, will continue to form a thick blanket wherever openings in the community occur and soil moisture is adequate. Russian thistle, as a species, can probably be considered an intermittent invader on the site. It will always be present to some degree owing to its occurrence in native vegetation. It is indeed typical of ephemerals that express themselves temporarily from time to time.

Cheatgrass maintained a relatively stable biomass but showed a $97 \%$ increase in. density between 1978 and 1979. The high seedling density which occurred from 1978 to 1979 illustrated the response of an annual grass to increased soil moisture. Increase in density between 1979 and 1980 was shown to be only $43 \%$. Cheatgrass was present predominantly in the subplots bordering native vegetation and in depressions where there was a greater accumulation of soil moisture for all growing seasons. During the first growing season following seeding, cheatgrass was a stronger competitor in mixtures seeded to native species as compared with introduced species. This may be a reflection of the lower use level of limiting growth resources by seeded species in the native mixtures as compared with the introduced and combination mix.tures.

The presence of cheatgrass seems to be stabilizing between seed mixtures and will probably start to show a gradual decrease during future growing seasons as the perennial grasses increase. The anticipated decrease in the presence of cheatgrass may be owed to the competitive advantage that established perennial species can exert over invading annuals.

Invading shrubs demonstrated a biologically significant increase in density over three growing seasons (Figure 18). A study done by Sindelar and Plantenberg (1978) presented similar findings regarding establishment by invading shrubs. They indicated that shrubs became an increasingly important component of the plant community as the seeded species became larger over time.

Shrubs were not a significant component of invasion until 1979 and 1980. During the last growing season rabbitbrush (Chrysothamnus spp.), greasewood (Sarcobatus vermiculatus), broom snakeweed (Gutierrezia sarothrae), and big sagebrush showed an increase in density and biomass above the previous two years (Figures 18 and 19). Greasewood was the only exception, with an increase in biomass in 1979 and a decrease in 1980. The biomass decrease in 1980 was believed to be a result of lower precipitation. Greasewood occurred primarily on areas of rather high sodium concentration. The increase in seedling density during the second year following planting is probably a result of increased soil moisture during the 1979 season. This shrub is a perennial, and subsequent growing seasons.will determine the survival of the new seedlings.

Greasewood and the forb species tumbling saltbush occur in the same area as a result of their capacity for salt tolerance and sparce stands of seeded species. The perennial nature of greasewood may eventually out-compete the annual tumbling saltbush in an exhibition of competition between invaders on an area where seeded species will not grow vigorousiy due to the condition of the soil. 
Broom snakeweed, big sagebrush, and rabbitbrush are commonly recognized as invading species indicative of disturbed areas. Broom snakeweed and rabbitbrush demonstrated a high frequency of occurrence in the native vegetation while big sagebrush was the major shrub species. The results of this study would seem to indicate an encroachment of invading shrubs as the plant community matures, at least on a temporary short-term bas is.

Rabbitbrush, broom snakeweed, and big sagebrush may also increase as the seed source provided by early invaders increases. The presently established invading shrub plants are expected to increase in biomass and percent canopy cover, potentially reducing the vigor of the surrounding seeded species.

Invading species within the seeded plant communities increased in diversity from year to year with the appearance of additional invading shrub species and chenopods. Tabie 10 summarizes the increase and pattern of diversity of invading species as they appeared in the seed mixtures over years. The increase in diversity of invading species il1 ustrates the dynamic nature of these communities as they relate to invasion and subsequent succession. Should a decrease in invaders become apparent in subsequent years, it would indicate that the

Table 10. Species diversity for invading species on the Shallowly Disturbed Successional Study.

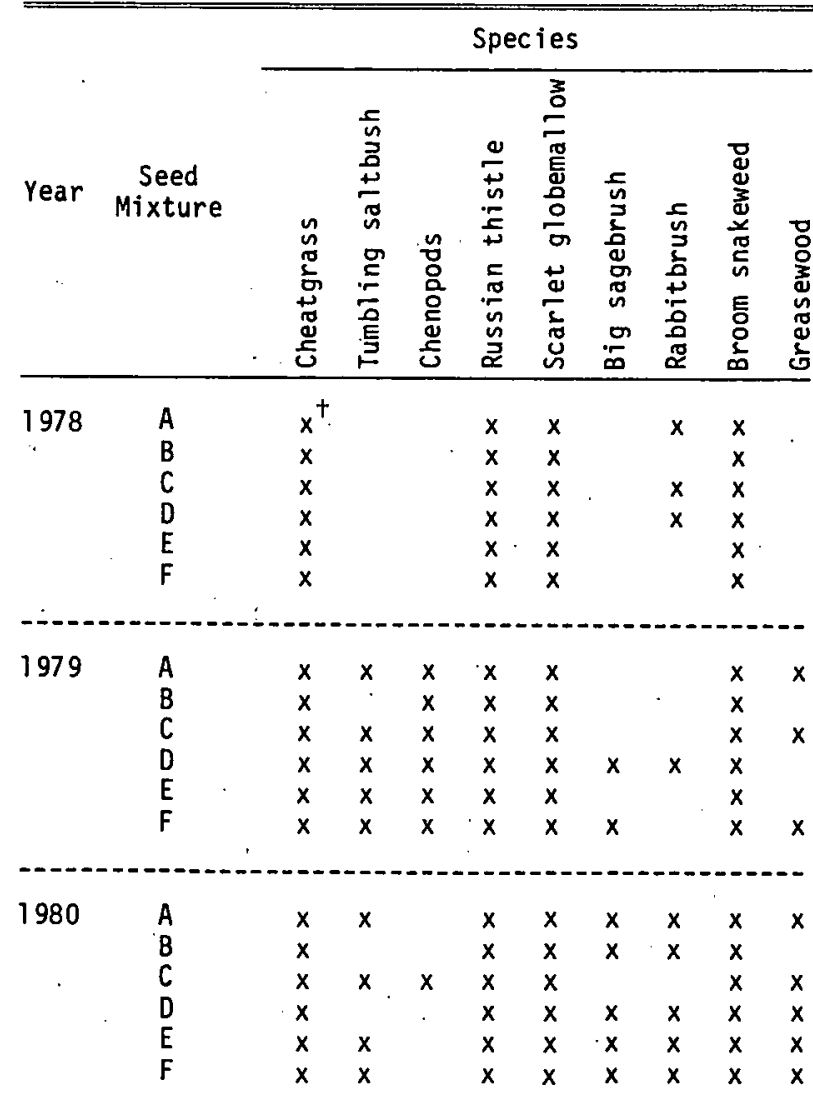

tindicates first recorded presence of species in seed mixture. seeded species are out-competing the invading species for the finite resources of nutrients, soil moisture, sunlight and space.

The general trend over the past three growing seasons appears to be one of increased invasion. There was an increase in density for the invading grasses, forbs, and shrubs that were sampled. An increase in the number of annual species is indicative of a plant community which is not closed. An increase in invading perennials illustrates that these invaders can maintain their presence and are capable of reproduction with in the seeded communities.

\section{Effects of Seed Mixture}

Invasion in 1980 was still generally lower in the introduced seed mixtures than in native seed mixtures. Less invasion in the introduced mixtures can be partially explained by the more robust plant growth exhibited by the seeded introduced than by the seeded native grasses. The level of cheatgrass was $58 \%$ higher in 1978 in native seed mixtures than in the introduced and combination mixtures. As native plant communities close and competition between seeded and invading species becomes more intense, native species appear to be exhibiting their competitive advantage in relationship to some invaders. This advantage is the result of the inherent adaptability of native species to their environment.

\section{Effects of Fertilizer}

Invading forbs and shrubs did not respond consistently to fertilization. However, cheatgrass exhibited a significant $(p=.05)$ increase in density across all fertilizer levels from 1978 to 1979 and 1979 to 1980 . The actual increase in invading plants is most likely a result of increased soil mo isture; however, the fertilizer effect is consistent, i.e., a slightly higher level of invasion under high fertilization (40 plants $/ \mathrm{m}^{2}$ in 1980) and a lower level under the control (32 plants $/ \mathrm{m}^{2}$ in 1980) existed.

Russian thistle showed a slightly negative biomass and density response to fertilization in 1980 , $9 \mathrm{~kg} / \mathrm{ha}$ under high fertilization and $15 \mathrm{~kg} / \mathrm{ha}$ under the control. The negative response exhibited by Russian thistle is the result of spatial limitations imposed on the establishment of this annual forb by the regenerating perennial species. Data for 1979 showed that the seeded species responded positively to the increased level of fertilizer which was applied before the second growing season, thereby decreasing the incidence of invasion by an annual forb such as Russian thistle. It should be noted that the response of the annual forbs tumbling saltbush and the Chenopodium spp. are not correlated with fertilizer levels. These two species are special cases which are responding more to the presence of sodium in the soil than to competition with seeded species.

Scarlet globemallow appeared to be unaffected by fertilization. The absence of a fertilizer response seems to be an inherent characteristic of this species. Globemallow appears to be well adapted to areas of low nitrogen conditions, and 
therefore its level of growth does not appear to be affected by nitrogen fertilizer.

The invading shrub species did not exhibit a clear response with regard to nitrogen fertilizer. This can be partially explained by the difficulty of establishment due to the spatial limitations imposed by the seeded grasses and forbs. This reaction may al so exhibit the lack of response of native shrubs to nitrogen fertilizer (Woodmansee et al. 1978).

\section{Effects of Muich}

Biomass of invading species was generally lower or showed no significant difference $(p=.05)$ on mulched subplots as compared with unmulched subplots for the first two growing seasons (Figure 20). The difference was not statistically significant for data collected in 1980. At this time the wood fiber hydromulch had almost completely decomposed. The lower incidence of invasion which occurred on the mulched plots would

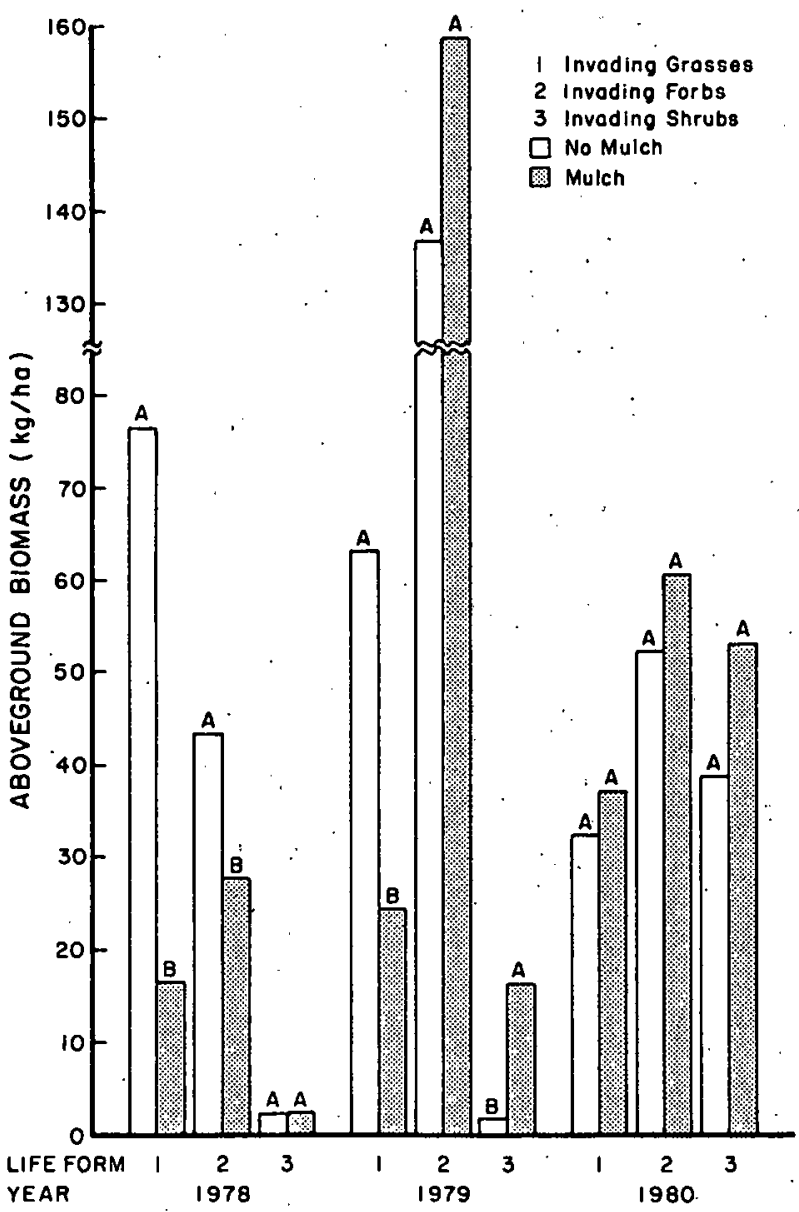

Figure 20. Biomass of selected invading species by mulching treatment across years on the Shallowly Disturbed Successional Study. (Treatments followed by the same letter are not significant at the :05 level.) seem to reaffirm the effectiveness of mulch in rapidly establishing a closed community during the early stages of community development. The proximity of native vegetation to the site perimeter increases the probability of invasion in the margin subplots; however, invasion was higher in the interior plots which were not muiched. The physical presence of the mulch on the soil surface served as a moisture conserving facility and enhanced the establishment and vigor of seeded species.

The density of invading forbs on both the mulched and unmulched plots in 1978 was due primarily to the presence of Russian thistle (Figure 21). The density of invading forbs however was increased in 1979 over 1978 by the presence of Chenopodium spp. and tumbling saitbush. The significantly greater number of scarlet globemallow. plants in 1980 maintained a high invading forb density even though Chenopodium spp. was not present in great numbers for that year.

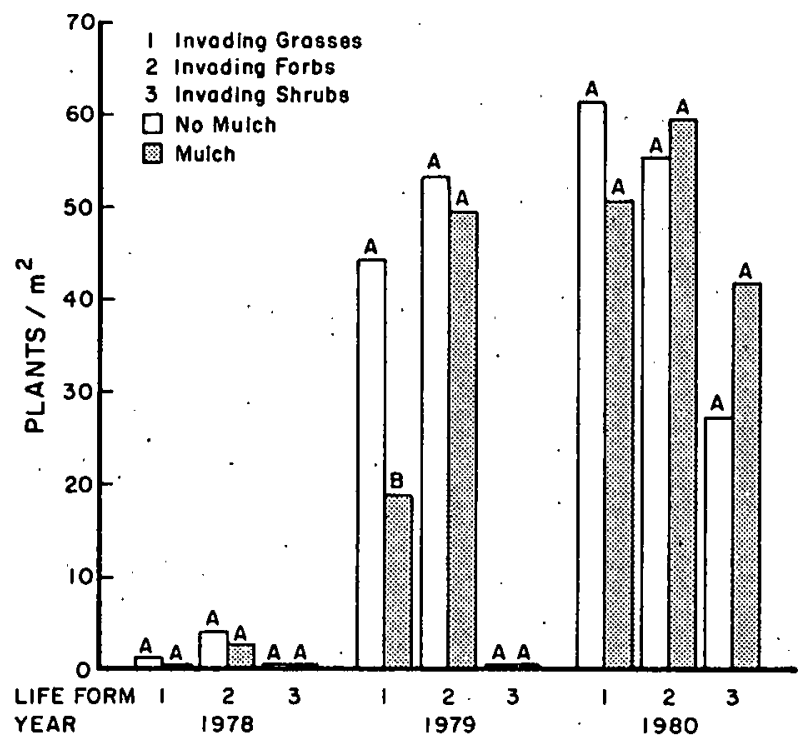

Figure 21. Density of selected invading species by mulching treatment across years on the Shallowly Disturbed Successional Study. (Treatments followd by the same letter are not significant at the .05 level.)

The presence of tumbling saltbush on the muiched plots accounted for a rather high portion of the density of forbs which occurred in 1979. As previously stated, only the subplots on the perimeter of the site were mulched. These subplots also contained a somewhat higher amount of sodium. It appears that the presence of high sodium levels along with high precipitation in 1979 rather than mulch accounted for the increased presence of this species. 
Applications for Reclamation Practices

Invading species do not appear to pose a serious threat to the successful establishment of seeded communities on the shallowly disturbed soils in the Piceance Basin. A comparison of the biomass estimates of seeded and invading species for 1979 showed invading species to represent only $7 \%$ of the total biomass on the area. Data collected during the 1981 growing season will provide additional information on the proportion of invading to seeded species on the site.

Invasion on a reclaimed area may be of importance only where environmental conditions are extreme. This study has illustrated that the presence of sodium on the reclaimed sites can place a severe restriction upon the successful establishment of a seeded plant community. Intensive soil testing is recommended to determine areas of high sodium concentration. An effective treatment for these areas might consist of seeding sodiumtolerant species or using soil amendments. If proper procedures to alleviate the problem are not followed, these areas will remain unproductive.

A comparison of plant density of the seeded species between 1978 and 1979 showed more plants in the introduced and combination species mixtures. It was also shown, however, that while total density is lower in native species the percentage increase from 1978 to 1979 was greater than for the introduced and combination mixtures. Density of seeded species in the native grass mixture increased $47 \%$ between 1978 and 1979; the introduced grass mixture showed an increase of $32 \%$. In the native grass-forb mixture density increased $49 \%$ between 1978 and 1979, while the increase in the introduced grass-forb mixture was $38 \%$. Data collected in 1981 will further clarify this relationship between native, introduced, and combination mixtures.

Invasion levels between seeded native and introduced mixtures showed that invasion was generally higher in the native mixtures. Cheatgrass, as indicated previously, showed a marked preference for invading the seeded native mixtures. Cheatgrass, however, seems to be exhibiting a gradual decline as the seeded native species regenerate. In contrast, scarlet globemallow invaded all mixtures at an almost equal level. It appears that invading annuals, such as cheatgrass, are more sensitive to competition from the seeded species while invading perennials are more competitive with seeded species over time. Favorable successive growing seasons following planting will determine the effectiveness of the seed mixtures in relation to each other.

Nitrogen fertilizer was applied on this study after the first growing season in an attempt to reduce the aggressiveness of annual invaders. The data seems to indicate, however, that cheatgrass still showed a greater response after fertilization than the control. The annual Chenopodizom spp. and tumbling saltbush were affected more by moisture than by time or amount of fertilizer application. Shrubs did not respond significantly to fertilizer. Data collected during 1979 showed a significant increase in seeded community production under high fertilization as compared to the control. Withholding fertilizer application was not conclusively shown to be an effective method for general invasion control.

The use of a hydromulch as a method for increasing vigor of seeded species and reducing invasion was not shown to be an effective long-term treatment. The- 1979 data demonstrated a lack of response by seeded species to the mulching treatment. Data analys is for 1980 showed no significant $(p=.05)$ difference between invasion on mulched and unmulched subplots. Based upon these results, use of hydromulch as a means of enhancing seeded community estabiishment on the Intensive Study Site should be questioned unless future data indicates otherwise. However, data on the number and quantity of invader species were less on mulched plots presumabiy because of increased vigor of the seeded species.

\section{Conclusions}

1. Invasion was generally lower in those seed mixtures containing introduced species, al though this difference was less apparent in 1980 as in the previous years following seeding in 1976 .

2. Community diversity increased between 1978 and 1979. Diversity was maintained in 1980 but density and biomass fluctuated within seed mixtures between each growing season.

3. Invading shrubs demonstrated a general increase in density as measured over three growing seasons following seeding.

4. Biomass and density of invading species were generally lower on mulched as compared to unmulched plots. The presence of wood fiber hydromulch resulted in a negative effect on invasion during early establishment of the seeded communities. As mulch became subject to decomposition, the negative effect appears to have faded.

5. Chenopodium spp. and Russian thistle appear to be recurrent invaders on this site, subject to available soil moisture.

6. Invasion by the perennial forb scarlet globemallow is approaching equality on all plots regardless of mixtures seeded.

7. The presence of high levels of sodium in the soil affected the type of invading species growing on the area. Greasewood and tumbling saltbush invaded these areas due, in part, to a lack of competition from seeded species.

\section{Revegetation Techniques Study}

\section{Introduction}

The Revegetation Techniques Study was established in the fall of 1976 to evaluate various cultural practices as they may influence the reestablishment of diverse and self-perpetuating ecosystems on intensively disturbed soils resulting from oil shale development. Six panels measuring $16 \times 92 \mathrm{~m}$ were scraper excavated to a depth of $1 \mathrm{~m}$ (Figure 22). The material from each panel was then 
$1-$ MIXTURE $2 \rightarrow+$ MIXTURE $1 \rightarrow+$ MIXTURE $3 \rightarrow$

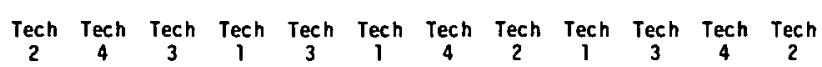

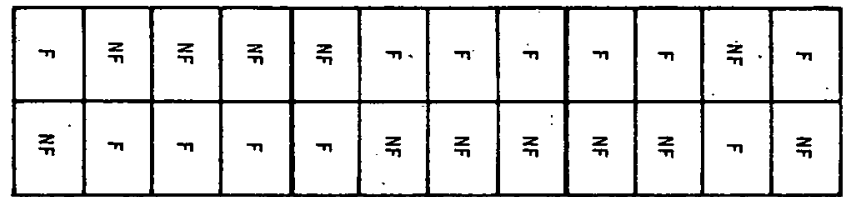

惫

$1-$ MIXTURE $2 \rightarrow+$ MIXTURE $1 \rightarrow+$ MIXTURE $3 \rightarrow-1$

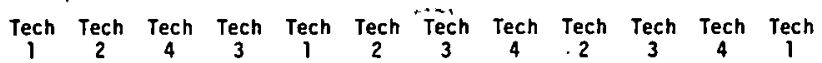

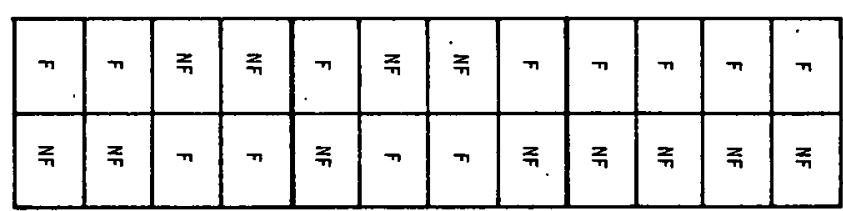
惫总

L MIXTURE $1 \rightarrow+$ MIXTURE $2 \rightarrow+$ MIXTURE $3 \rightarrow-1$ Tech Tech Tech Tech Tech Tech Tech tech Tech Tech tech tech

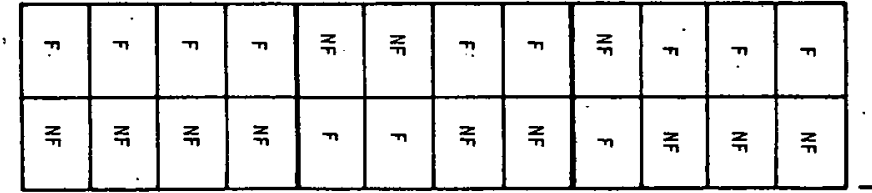

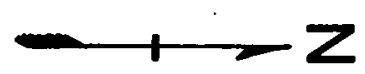

F-MIXTURE $2 \rightarrow-$ MIXTURE $3 \rightarrow+-$ MIXTURE $1 \rightarrow$ Tẹch Tech Tech Tech Tech Tech Tech tech Tech Tech tech Tech

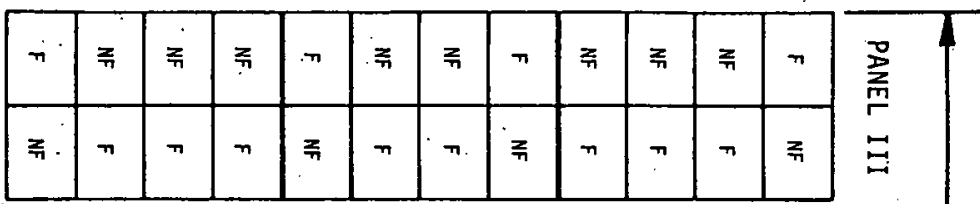

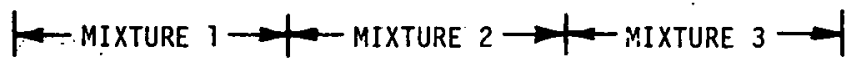
Tech. Tech Tech, Tech Tech Tech Tech Tech Tech Tech Tech Tech

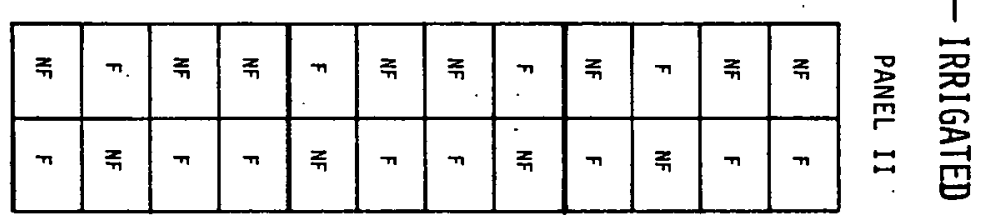

$\vdash$ MIXTURE $3 \rightarrow+$ MIXTURE $1 \rightarrow+$ MIXTURE $2 \rightarrow$ Tech Tech Tech Tech Tech Tech Tech Tech Tech Tech Tech Tech

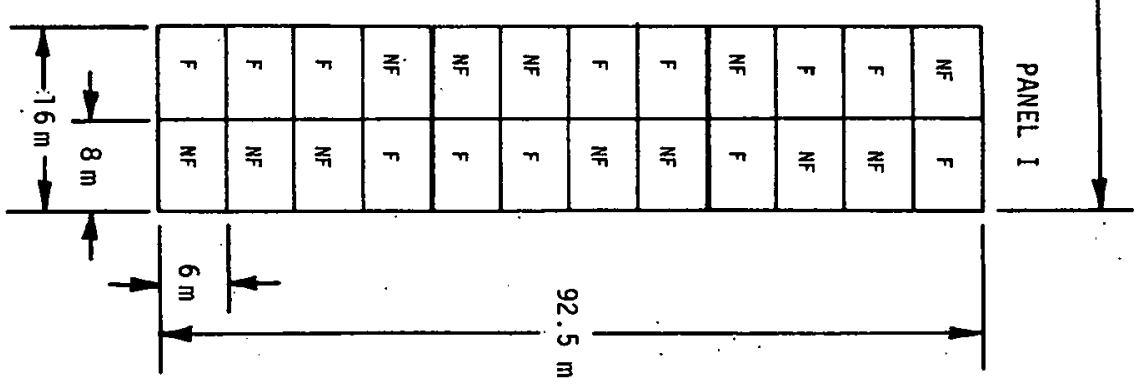


mixed and returned to the excavation. Each panel had a series of 24 plots that had all possible combinations of seed mixtures (Table 1.1), seeding technique, and fertilizer treatments. Thus, a reclamation situation where the plant growth medium included mixing shallow layers of topsoil with underlying subsoil material was simulated. The revegetation of this heterogeneous topsoilsubsoil mixture is difficult since it presents a rocky and nutrient-deficient seedbed and rooting medium. The various cultural treatments being evaluated include seeding technique, seed mixture, fertilization, and irrigation. The four seeding techniques being studied were:

Technique 1: Grass, forb, and shrub mixtures drilled at a rate of $17 \mathrm{~kg} / \mathrm{ha}$

Technique 2: Grass, forb, and shrub mixtures drilled at a rate of $19 \mathrm{~kg} / \mathrm{ha}$ with a decreased grass and forb seeding rate and an increased shrub seeding rate

Technqiue 3: Grasses and forbs drilled at a rate of $17 \mathrm{~kg} / \mathrm{ha}$

Technique 4: Grasses and forbs broadcasted at a rate of $29 \mathrm{~kg} / \mathrm{ha}$ and lightly covered with soil.

Three seed mixtures of various combinations of grasses, forbs, and shrubs were evaluated in this study (Table 11). They are: (1) a combination mixture of native and introduced species, (2) a native species mixture, and (3) an introduced species mixture. Half of the study was fertilized with $112 \mathrm{~kg} \mathrm{~N} / \mathrm{ha}$ and $90 \mathrm{~kg} \mathrm{P} / \mathrm{ha}$ while the remaining half was unfertilized. One-half of the study (including fertilized plots) was irrigated the first two growing seasons. Supplementai water was added on a weekly basis beginning early in June to balance any deficit in the maximum natural precipitation expected $(2.5 \mathrm{~cm} /$ week). The entire study was hydromulched with wood fiber a t a rate of $2.2 \mathrm{MT} / \mathrm{ha}$. The experimental design was a split-split plot (Figure 22).

The responses of vegetation to various cultural treatments were measured using quadrat, stand evaluation (Cook et al. 1967), and line intercept sampling. Permanent $0.25-\mathrm{m}^{2}$ quadrats were used to measure seeded grass, forb, and shrub density, canopy cover, and biomass. In addition, line intercept sampling provided density and canopy cover estimates for shrub species to provide a more accurate estimate of shrub responses. Stand evaluation provided information on number and distribution of invading species within treatments.

Diversity was estimated using Shannon-Weiner index (Shannon and Weaver 1973) and using a ratio of the relative cover of each species to the total cover of all species (Bonham 1974). Higher diversity indices indicate higher structural diversity and possibly greater plant stand stability.

\section{Results and Discussion}

Differing degrees of surface rockiness $(>2 \mathrm{~mm}$ ) cover and rock size in the substrate were found among the six panels (Table 12). Otherwise, all panels had similar soil characteristics such as $\mathrm{pH}$, water infiltration rates, electrical conductivities, and compaction. Degree of surface and subsurface rockiness was derived from ocular estimates from quadrat data and exploratory pits. respectively (Table 12). It has been reported that as the percentage of coarse fragments in soil material increases, the suitability of that soil material for revegetation decreases (Berg et al. 1979). Therefore, vegetation responses were analyzed using a nested design which incorporated the varying degrees of surface and subsurface rockiness.

Fourwing saltbush and winterfat are the dominant seeded shrubs. Stansbury cl iffrose (Cowania mexicana stansburiana) and green ephedra (Ephedra viridis) have achieved only limited establ ishment success as evidenced by their low biomass and comparatively small plants. This may be attributed to grass competition (Redente et al. 1980). Antelope bitterbrush (Purshia tridentata) has been considerably less successful, and Siberian peashrub and Russian olive can no longer be found on the study plots. Therefore, fourwing saltbush and winterfat are the major shrubs considered in the discussion of seeded shrubs.

\section{Effects of Rockiness}

The effects of rockiness on seeded shrubs is not clearly understood. "However, some literature indicates that rockiness may benefit shrubs. Hillel and Tadmore (1962) reported that rocky soils experienced lower water storage capacities (i.e., smaller retensions per unit of depth) and the depth of water penetration was increased. This would be more advantageous to the deep-rooted fourwing saltbush than the more shallow-rooted grasses. Thereby, water competition between fourwing saltbush and the seeded grasses would be reduced, but not entirely eliminated. Generally, increased subsurface rockiness lowered the overall productivity of the site and changed the species composition by increasing fourwing saltbush and decreasing seeded grasses on nonirrigated plots (Figure 23). However, Panel II had the highest subsurface rockiness and the lowest shrub cover.

The high surface rockiness in Panel III may have caused poor seed-to-soil contact and a droughty seedbed condition. In any event, the higher surface rockiness in Panel III appears to have restricted forbs and grasses more than the shrubs. Results from Panel I did not seem to show that rockiness favored either grasses and forbs or shrubs since it had comparatively smaller quantities of rocks in the soil profile. Further study is underway to explain the effect or rockiness more completely. Winterfat was not significantly affected by rockiness. Competition with fourwing saltbush probably suppressed winterfat increases on rockier soils. Under irrigation there was no effect of rockiness on the stands of various life forms. Irrigation continually recharged these intensively disturbed soils, thereby reducing competition for moisture among all life forms.

Subsurface rockiness and total rockiness of the soil profile affected biomass $(p=.25)$ of seeded grasses, but only on nonirrigated plots (Figure 23). Seeded grass biomass was greatest in Panel I, 
Table 11. Seeding mixtures and rates used on the Revegetation Techiques Study.

Common Name

Scientific Name

Seeding Rate PLS.( $\mathrm{kg} / \mathrm{ha})$

Tech 1 Tech $2 \quad$ Tech $3 \quad$ Tech 4

Mixture 1--Combination (native and introduced) species

1. Nordan crested wheatgrass

2. Siberian wheatgrass

3. Critana thickspike wheatgrass

4. Sodar streambank wheatgrass

5. Slender wheatgrass

6. Regar meadow brome

7. Indian ricegrass

8. Green needlegrass

9. Durar hard fescue

10. Madrid yellow sweetclover

11. Sweetvetch

12. Globemallow

13. Lewis flax

14. Arrowleaf balsamroot

15. Fourwing saltbush

16. Stansbury cliffrose

17. Winterfat

18. Green ephedra

Mixture 2--Native species

1. Rosana western wheatgrays

2. Sodar streambank wheatgrass

3. Bearded bluebunch wheatgrass

4. Indian ricegrass

5. Green needlegrass

6. Durar hard fescue

7. Shermans big bluegrass

8. Alkali sacaton

9. Globemallow

10. Sweetvetch

11. Palmer penstemon

12. Stansbury cliffrose

13: Green ephedra

14. Fourwing saltbush

15. Winterfat

16. Antelope bitterbrush
Agropyron cristation

Agropyron sibericum

Agropyron dasystachyum

Agropryon riparion

Agropyron trachycaulum

Bromus erectus

Oryzopsis hymenoides

Stipa viridula

Festuca ovina duriuscula

Melizotus officinalis

Hedysamon boreale

Sphaeralcea munroana

Linum lewisii

BaZsamhoriza sagittata

Atriplex canescens

Cowania mexicana stansburiana

Ceratoides Zanata

Ephedra viridis

Total

Agropyron smithii

Agropyron riparizon

Agropyron spication

Oryzopsis hymenoides

Stipa viridula

Festuca ovina duriuscula

Poa amola

Sporobolus airoides

sphaeralcea munroana

Hedysamm boreale

Penstemon palmeri

Cowania mexicana stansbraiana

Ephedra viridis

Atriplex canescens

Ceratoides lonata

Purshia tridentata

\begin{tabular}{|c|c|c|c|}
\hline $\begin{array}{l}1.12 \\
1.12 \\
1.12 \\
1.12 \\
1.12 \\
1.12 \\
1.12 \\
1.12 \\
0.56 \\
0.56 \\
1.12 \\
0.56 \\
0.56 \\
1.12 \\
1.12 \\
1.12 \\
1.12 \\
1.12\end{array}$ & $\begin{array}{l}0.56 \\
0.56 \\
0.56 \\
0.56 \\
0.56 \\
0.56 \\
0.56 \\
0.56 \\
0.28 \\
0.28 \\
0.56 \\
0.56 \\
0.56 \\
0.56 \\
4.48 \\
3.36 \\
2.24 \\
2.24\end{array}$ & $\begin{array}{l}1.12 \\
1.12 \\
2.24 \\
2.24 \\
2.24 \\
1.12 \\
2.24 \\
2.24 \\
0.56 \\
0.56 \\
1.12 \\
0.56 \\
0.56 \\
1.12 \\
--.- \\
--- \\
---- \\
--.-\end{array}$ & $\begin{array}{l}1.12 \\
2.24 \\
3.36 \\
3.36 \\
3.36 \\
2.24 \\
2.24 \\
3.36 \\
1.12 \\
0.56 \\
1.68 \\
1.12 \\
1.12 \\
1.68 \\
-.- \\
-.- \\
-.-\end{array}$ \\
\hline .9 & 9.60 & 19.04 & 29.68 \\
\hline
\end{tabular}

1.12

1.12

1.12

1.12

1.12

0.56

1.12

0.56

0.56

1.12

0.56

2.24

1.12

1.12

1.12

1.12

Total

16.80

0.56

0.56

0.56

0.56

0.56

0.28

0.56

0.28

0.28

0.56

0.28

4.48

3.36

3.36

2.24

3.36

21.84

15.68

3.36

1.12

2.24

2.24

2.24

0.56

I. 12

0.56

0.56

1.12

0.56

----

---

- - -
4.48

2.24

4.48

4.48

1.12

1.12

1.12

1.12

1.12

-...-

-.-

-

$\ldots$

26.88

\section{Mixture 3--Introduced species}

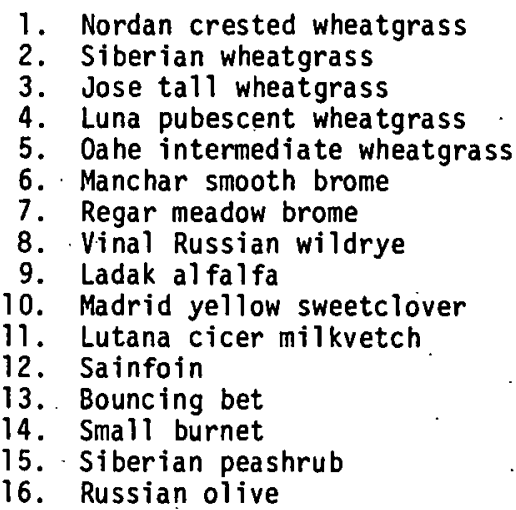

Agropyron cristatum Agropyron sibericum Agropyron elongation Agropyron trichophorum Agropyron intermedium Bromus inermis Bromus erectus Elymus junceus Medicago sativa Melizotus officinalis Astragalus cicer Onobrychis viciaefolia Saponaria officinalis Sanguisorba minor Caragana arborescens Elaeagnus angustifolia

\begin{tabular}{llll}
1.12 & 0.56 & 2.24 & 3.36 \\
1.12 & 0.56 & 1.12 & 2.24 \\
1.12 & 0.56 & 2.24 & 3.36 \\
1.12 & 0.56 & 1.12 & 2.24 \\
1.12 & 0.56 & 1.12 & 2.24 \\
1.12 & 0.56 & 1.12 & 2.24 \\
1.12 & 0.56 & 2.24 & 4.48 \\
1.12 & 0.56 & 1.12 & 2.24 \\
0.56 & 0.28 & 0.56 & 1.12 \\
0.56 & 0.28 & 0.56 & 1.12 \\
0.56 & 0.56 & 0.56 & 1.12 \\
0.56 & 0.56 & 0.56 & 1.12 \\
1.12 & 1.12 & 1.12 & 2.24 \\
1.12 & 1.12 & 1.12 & 2.24 \\
1.12 & 4.48 &.--- & ---- \\
2.24 & 4.48 &.--- & $-\therefore--$ \\
\hline 16.80 & 17.36 & 16.80 & 31.36
\end{tabular}


Table 12. Surface and subsurface rockiness on the Revegetation Techniques Study.

\begin{tabular}{|c|c|c|c|c|c|}
\hline & \multicolumn{5}{|c|}{ Average Percent Rockiness ${ }^{\dagger}$} \\
\hline & \multicolumn{4}{|c|}{ Surface } & \multirow{2}{*}{$\begin{array}{c}\text { Subsurfac } \\
\text { Total } \\
\text { Rock }\end{array}$} \\
\hline & $\begin{array}{l}\text { Sma } 11^{\S} \\
\text { Rock }\end{array}$ & $\begin{array}{l}\text { Mediums } \\
\text { Rock }\end{array}$ & $\begin{array}{l}\text { Large* } \\
\text { Rock }\end{array}$ & $\begin{array}{l}\text { Total } \\
\text { Rock }\end{array}$ & \\
\hline Nonirrigated & & & & & \\
\hline $\begin{array}{l}\text { Panel I } \\
\text { Panel II } \\
\text { Panel III }\end{array}$ & $\begin{array}{l}16 \\
40 \\
20\end{array}$ & $\begin{array}{r}3 \\
9 \\
18\end{array}$ & $\begin{array}{r}2 \\
5 \\
47\end{array}$ & $\begin{array}{l}21 \\
54 \\
85\end{array}$ & $\begin{array}{c}6 \\
35 \\
28\end{array}$ \\
\hline \multicolumn{6}{|l|}{ Irrigated } \\
\hline $\begin{array}{l}\text { Panel I } \\
\text { Panel II } \\
\text { Panel III }\end{array}$ & $\begin{array}{r}37 \\
28 \\
6\end{array}$ & $\begin{array}{r}12 \\
27 \\
4\end{array}$ & $\begin{array}{r}7 \\
20 \\
0\end{array}$ & $\begin{array}{l}56 \\
75 \\
20\end{array}$ & $\begin{array}{l}43 \\
60 \\
20\end{array}$ \\
\hline
\end{tabular}

tRockiness averages are derived from ocular estimates of percentage rock cover on the surface of the ground and on the wall of exploratory excavations.

${ }^{5} S$ mall rock $=0.2-1.0 \mathrm{~cm}$ in diameter.

TMedium rock $=1.0-3.0 \mathrm{~cm}$ in diameter

*Large rock $=3 \mathrm{~cm}$ in diameter or greater.

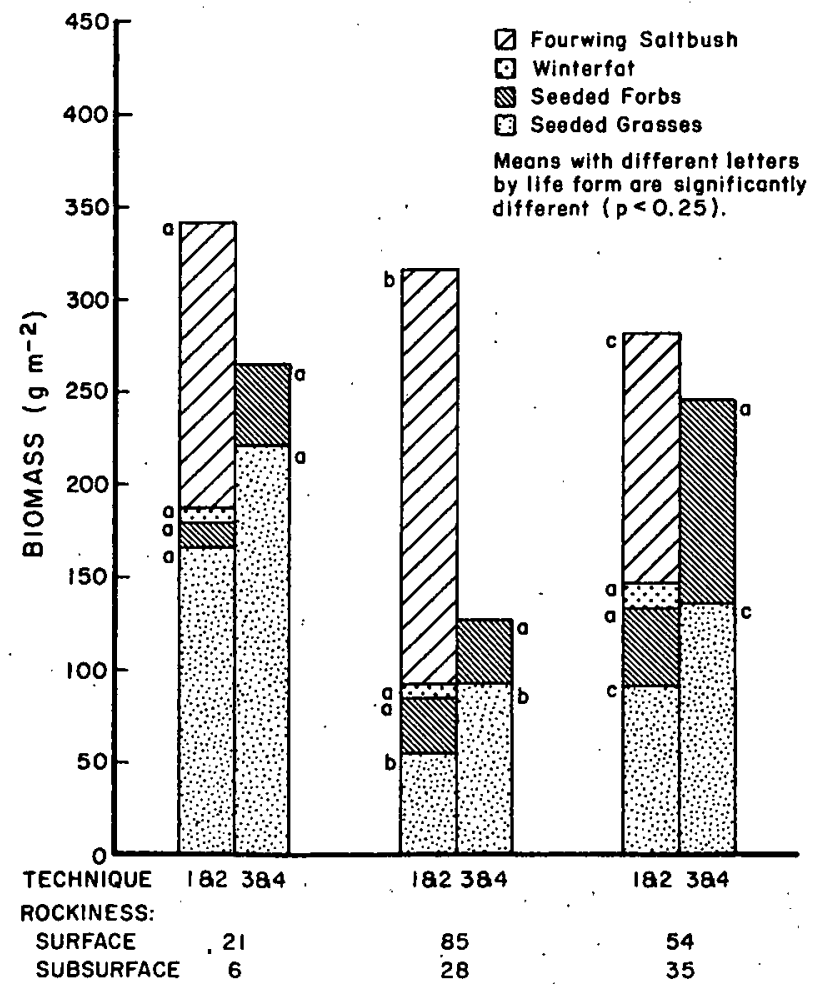

Figure 23. Average biomass of nonirrigated seeded grasses, forbs; and shrubs affected by rockiness.

intermediate in Panel II, and least in Panel III. This correlates with the degree of surface rockiness in the soil and could have been a vital factor in the emergence and survival of grass seedlings. Irrigation, however, appears to mitigate the effect of rockiness. Rockiness had no significant effect on forb cover and biomass.

Increased surface rockiness increases $(p=.25)$ the densities of invading forbs on both irrigated and nonirrigated plots of all seeding techniques. Biomass and cover of invading forbs were unaffected. Surface rockiness appears to provide a favorable microsite (Evans and Young 1972) for invading forbs to establish. This microsite advantage is reduced with irrigation.

\section{Effects of Seed Mixture}

The expression of fourwing saltbush was not significantly affected by either the combination seed mixtures or the native seed mixture (Figure 24) in which it appeared. Fourwing saltbush competes rather successfully unless grass and forb stands are dense. The seeding rates of grasses and forbs were apparently low enough in these mixtures to allow fourwing saltbush to become established and produce vigorous plants on these rather severely disturbed soils. Winterfat produced significantiy greater cover $(p=.25)$ and densities $(p=.10)$ in the combination mixtures than in the native seed mixture on both irrigated and nonirrigated plots (Figure 24).

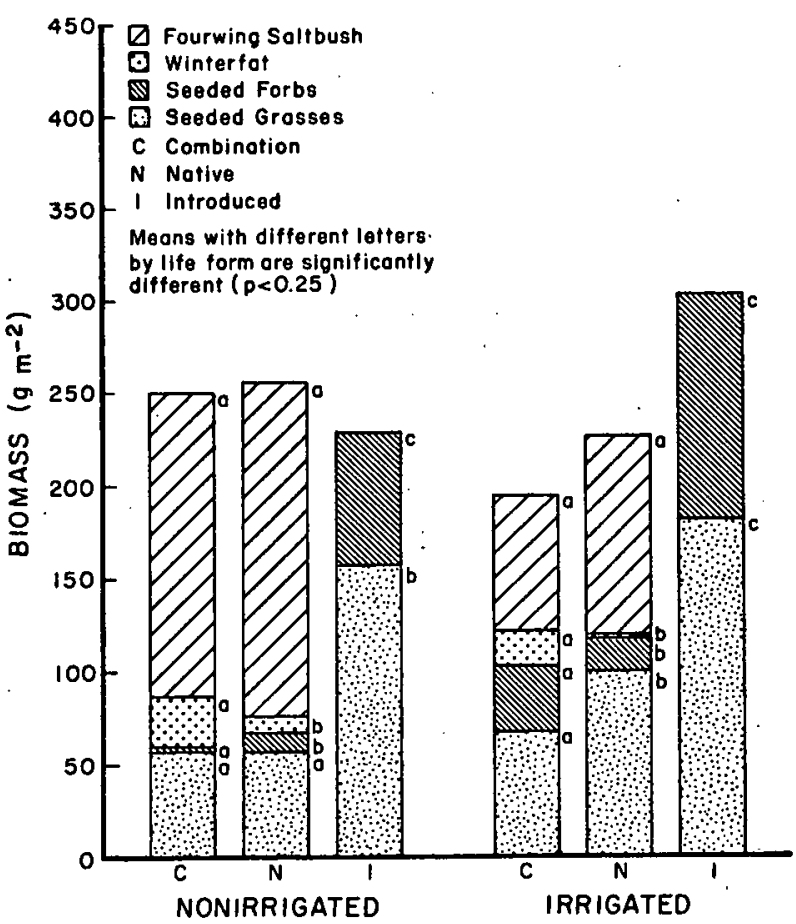

Figure 24. Average biomass of Techniques 1 and 2 for seeded grasses, forbs, and shrubs as affected by seed mixture and irrigation. 
Mixtures of seed are confounded when comparing them across all, so called, technqiues because Techniques 3 and 4 had no shrubs in the mixture. Therefore, mixtures of all three life forms can be discussed only for Techniques 1 and 2 (Figure 24). The introduced seed mixture had no surviving shrubs; therefore, grass cover values were greatest in the introduced seed mixture $(12.8 \%)$, followed by the native seed mixture $(8.8 \%)$, and least in the combination seed mixture $(8.1 \%)$. Irrigation in all cases increased the production of grasses. The biomass of grasses on irrigated plots was greatest in the introduced seed mixture $\left(182 \mathrm{~g} \mathrm{~m}^{-2}\right)$, least in the combination $\left(69 \mathrm{~g} \mathrm{~m}^{-2}\right)$, and intermediate in the native seed mixture $\left(100 \mathrm{~g} \mathrm{~m}^{-2}\right)$. Cover values followed the same order $(14.0 \%>11.2 \%>1.0 .0 \%)$ as biomass for introduced, native, and combination seed mixtures, respectively.

Since shrubs were not seeded in Techniques 3 and 4 , the seeded grasses and forbs of all three seed mixtures have equal opportunity to express themselves without shrub competition (Figure 25). In this case, seeded grasses of the native seed mixture out-produced the grasses of the combination seed mixture on nonirrigated plots (Figure 25). On irrigated plots, grasses in the introduced seed mixture had $183 \mathrm{~g} \mathrm{~m}^{-2}$ biomass compared to $128 \mathrm{~g} \mathrm{~m}^{-2}$ in the native seed mixture and $125 \mathrm{~g} \mathrm{~m}^{-2}$ in the combination seed mixture.

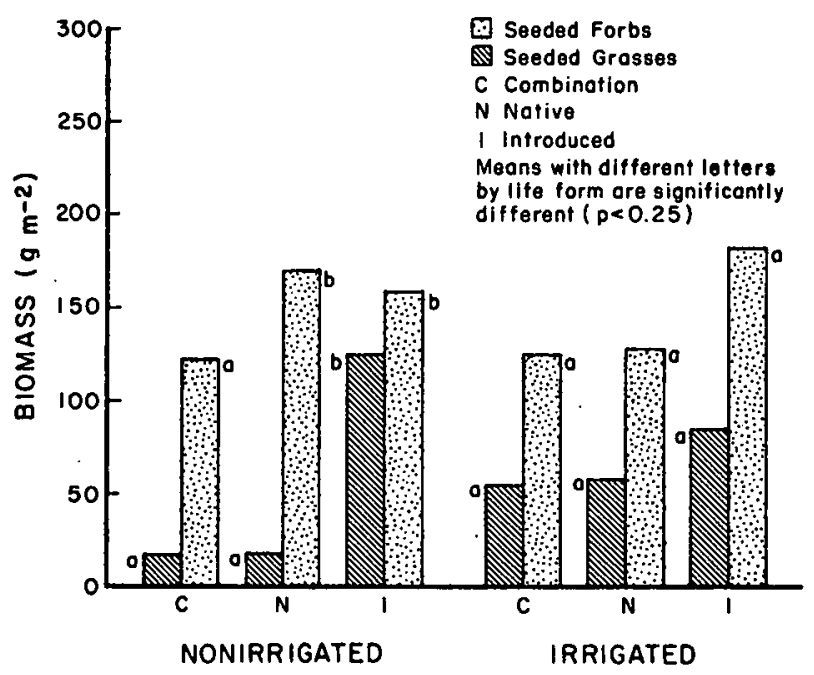

Figure 25. Average biomass of nonirrigated and irrigated Technqiues 3 and 4 seeded forbs and grasses affected by seed mixture.

Generally, seeded forbs produced greater biomass $(p=.10)$ and cover $(p=.10)$ in the introduced seed mixture as compared to the native and combination seed mixtures under both irrigated and nonirrigated conditions of Techniques 1 and 2 (Figure 24). There was no shrub competition in the introduced seed mixtures because all introduced shrubs had a $100 \%$ mortality. Therefore, forbs in the introduced seed mixture had greater biomass than forbs in combination and native seed mixtures
(Figure 24). However, Techniques 3 and 4 had no shrubs seeded in any of the seed mixtures. Forbs in the introduced seed mixtures still produced more biomass than forbs in the native and combination mixture (Figure 25). This was expected because introduced forb species are generaliy more robust than native forb species. Invading forb biomass was greater $(p=.25)$ in the native seed mixture plots $\left(2.9 \mathrm{~g} \mathrm{~m}^{-2}\right)$ compared to combination seed mixtures $\left(1.6 \mathrm{~g} \mathrm{~m}^{-2}\right)$ and introduced seed mixtures $\left(1.9 \mathrm{~g} \mathrm{~m}^{-2}\right)$. This indicates that species in the native seed mixture did not use space and resources as completely as did the seeded species in the introduced and combination seed mixtures.

\section{Effects of Seeding Techniques}

Seeding Technique 2 had an increased shrub seeding rate and a reduction in the grass and forb seeding rate compared to Technique 1. Seeding Technique 2 produced greater fourwing saltbush cover than did Technique 1 under both irrigated and nonirrigated conditions (Figure 26). The higher grass seeding rate of Technique 1 did not allow robust fourwing saltbush growth compared to Technique 2. Winterfat was not significantly affected by seeding technique under either irrigated or nonirrigated conditions (Figure 26). Fourwing saltbush seeding rate was increased 3.5-fold whereas the winterfat rate was increased only twofold from Technique 1 to Technique 2. Also, fourwing saltbush appears to be a more competitive species than winterfat. Therefore, saltbush may reduce winterfat vigor and numbers through competition for moisture and nutrients. In addition, winterfat has a developed fibrous root system as well as a tap root enabling it to use shallow

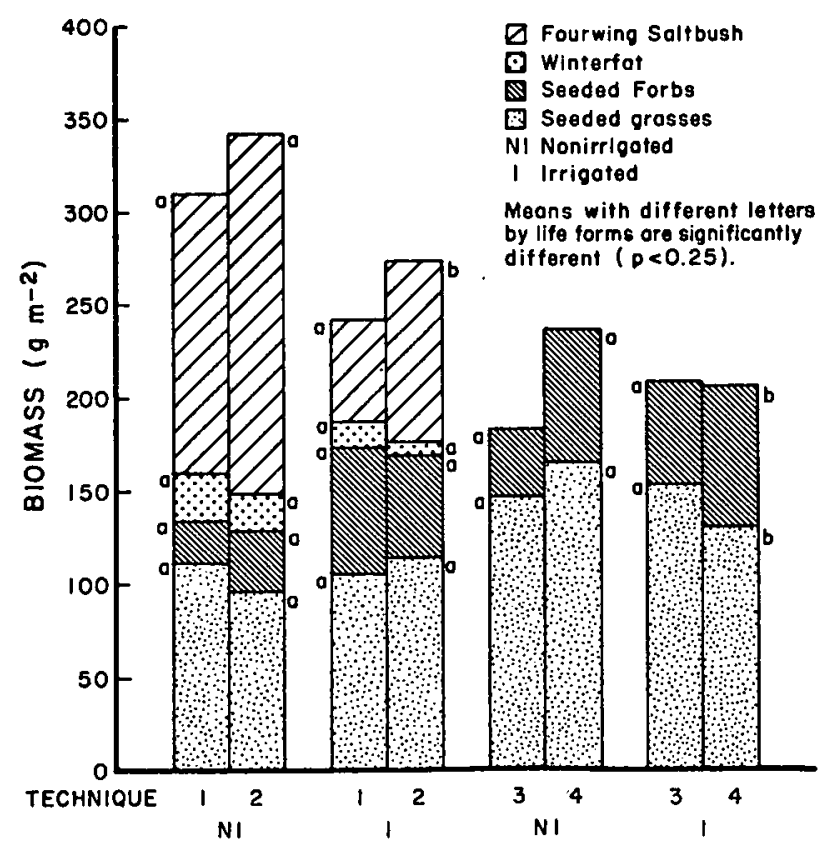

Figure 26: Average biomass of seeded grasses, forbs, and shrubs as affected by seeding technique. 
surface moisture which may have resulted in competition with grasses for this moisture.

Seeded grass densities were significantly $(p<.25)$ increased with the use of seeding Technique $1\left(41 \mathrm{~m}^{-2}\right)$ compared to Technique $2\left(35 \mathrm{~m}^{-2}\right)$. Grasses seeded with Technique 1 were seeded at twice the rate of Technique 2, thus resulting in smaller but more individual grass plants.

Technique 3 (drill seeding) produced significantly $(p=.25)$ greater grass biomass than Technique 4 (broadcast seeding) under irrigation (Figure 26). However, no significant difference was found between the biomass of grasses of Techniques 3 and 4 without irrigation. It should be remembered that seed was applied under broadcasting at twice the rate as drilling. There was no significant difference in forb biomass between Techniques 1 and 2, regardless of irrigation regime (Figure 26). Technique 4 produced more forb biomass than did Technique 3 in both irrigated and nonirrigated plots (Figure 26). This indicates that broadcast seeding reduces competition between grasses and forbs compared to drill seeding. Densities of forbs in Techniques 3 and 4 plots were similar. Since densities remained essentially unchanged, there may be no establishment advantage with the broadcast technique. However, the more vigorous forbs in Technique 4 plots probably would withstand a series of drought years more successfully than forbs in Technique 3 if root systems of forbs in Technique 4 are more developed.

Invading forb densities were significantly greater $(p=.25)$ with the use of seeding Technique 3 $\left(21.7 \mathrm{~m}^{-2}\right)$ compared to. Technique $4\left(7.4 \mathrm{~m}^{-2}\right)$. The density and biomass of invading forbs were reduced with the use of Technique $1 .\left(23 \mathrm{~m}^{-2}\right.$ and $\left.0.9 \mathrm{~g} \mathrm{~m}^{-2}\right)$, as compared to Technique $2\left(28 \mathrm{~m}^{-2}\right.$ and $3 \mathrm{~g} \mathrm{~m}^{-2}$ ) under both irrigated and nonirrigated conditions. This occurred because of an increased tendency of grasses in Technique 1 plots to close the comminity rather rapidly compared to Technique 2 which had more shrubs and less grasses, thus leaving open spaces for invasion.

\section{Effects of Fertilizer}

Fourwing saltbush showed no significant cover or density response because of fertilization (Figure 27) except on rockier sites where fertilization somewhat increased fourwing saltbush biomass. Fertilizer may leach down in rockier subsoils where the deep-rooted browse species can take advantage of it. Thus, fourwing saltbush may benefit from fertilizer which is out of the reach of the grass roots.

Fertilization did not increase the biomass of seeded grasses in all cases (Figure 27). However, in most instances grasses were increased by fertilizer rather significantly. Cumulatively, total biomass of grasses, forbs, and shrubs was not significantly increased with fertilizer applications because there was often not enough available water for fertilization to be beneficial. Additions of nitrogen fertilizer on dry sites may, in fact, be damaging as the stimulation of plant growth may lead to severe water stress (Vallentine 1977). The high salt index of ammonium nitrate may increase osmotic pressure under nonirrigated condi-

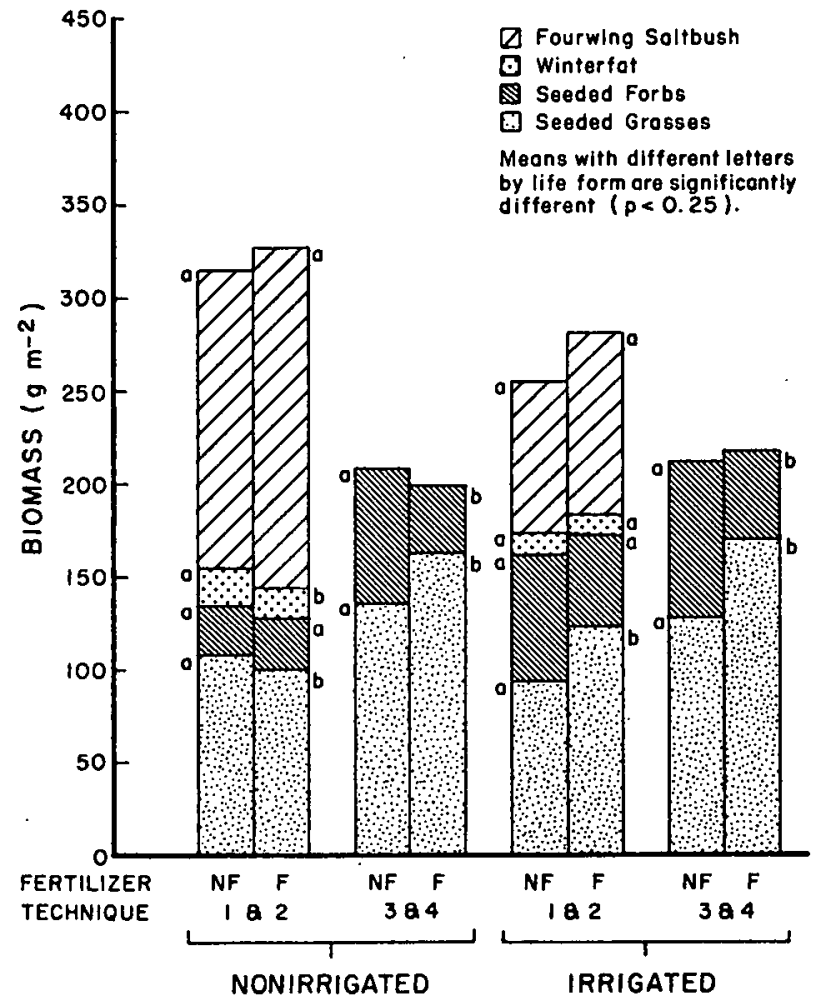

Figure 27. Average biomass of seeded grasses, forbs, and shrubs as affected by fertilization.

tions, thereby subjecting seedlings to water stress (Tisdale and Nelson 1975). Also, interspecies competition may be severe with increases in one species being negated by decreases in another. Fertilizer additions with irrigation may cause vigorous introduced grass growth at the expense of forb and shrub growth. Acceierating competition even more for nutrients, water, and space may negate any gains from fertilizer applications. Finally, the effects of fertilizer may be diminished three years after application (Cook 1965).

Fertilization produced no significant increase on seeded forb biomass, cover, or density on either irrigated or nonirrigated treatments over all techniques. Again, fertilizer effects may be exhausted since it has been three years since the application of the fertilizer. It was suggested by cosper et al. (1967) that nitrogen fertilization favored grass growth and that shrubs and forbs, as a result, may suffer from increased competition. Most of the forbs in the trials are nitrogen fixers, and fertilization may negate this competitive advantage over grasses. The exceptional response was in the native seed mixture, where with the use of fertilizer sweetvetch doubled in Technique 3 and globemallow quadrupled in Technique 4 compared to no fertilizer.

Fertilization did not significantly affect invading forb density, biomass or cover on irrigated and nonirrigated plots when seeding Technqiues? and 2 were used. The biomass of invading forbs was 
significantly decreased $(p=.25)$ with fertilization on nonirrigated Technique 3 and 4 plots compared to nonfertilized, nonirrigated plots. There were no material differences on the irrigated plots for seeding Techniques 3 and 4 . Invading grasses also showed no responses attributable to fertilization on any of the treatments.

\section{Effects of Irrigation}

Seeded grasses on piots irrigated in 1977 and 1978 did not produce greater biomass than nonirrigated plots in 1980 (Figure 28). Irrigation in previous years, however, did increase seeded grass biomass. Irrigation allowed the seeded grasses to grow beyond the abilities of the site to sustain such biomass without continued supplemental water. Seeded grasses have since competed among themselves and apparently died back to a nonirrigated level. Irrigated seeded grass densities remained bigher in 1980 than those of the nonirrigated grasses but cover and biomass values were comparable. This recent reduction in biomass of seeded grasses appears to have coincided with an increase in biomass, cover, and density of seeded forbs. This indicates an ability of seeded forbs to occupy some space released by the reduction in grasses. Seeded shrubs on irrigated plots produced lower cover and biomass but higher densities than nonirrigated seeded shrubs.

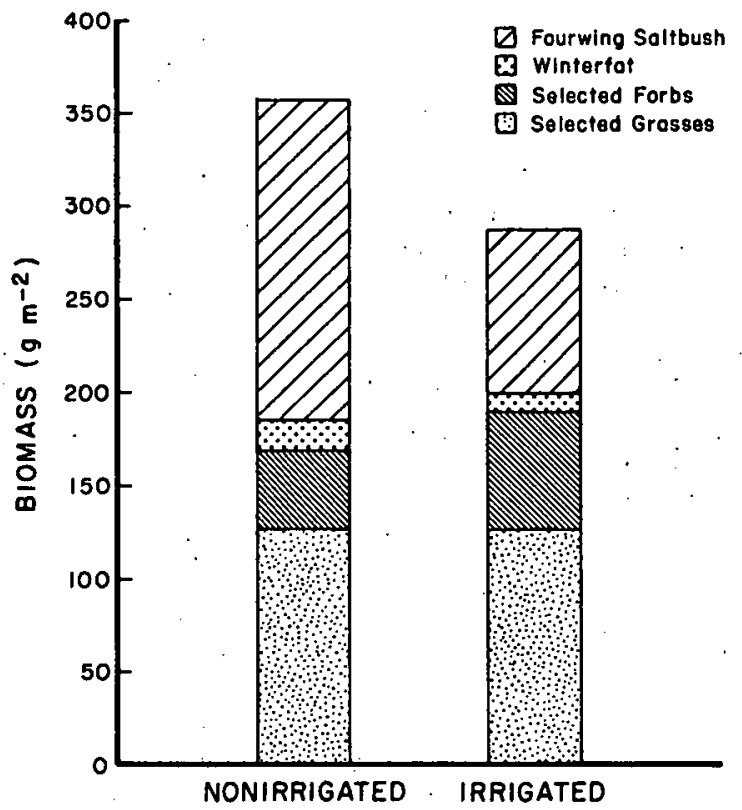

Figure 28. Average biomass of seeded grasses, forbs, and shrubs as affected by irrigation.

\section{Vegetation Successional Trend}

Vegetation successional trends were analyzed in order to obtain a preliminary indication of the direction and rate of plant community changes.
Analysis involved the comparison of 1978 quadrat data after one growing season to 1980 quadrat data.

All three seed mixtures increased their total biomass from 1978 to 1980 both with and without the aid of fertilization or irrigation. Introduced species made larger biomass gains than native species. The mixing of native and introduced species appears to be of little benefit to total biomass production after three years since they responded about the same as when seeded separately. The introduced species showed a decline in plant numbers from 1978 to 1980 , whereas native species gained in numbers. Western whea tgrass, streambank wheatgrass (Agropyron riparium), and other wheatgrasses composed the largest proportion of the density, cover, and biomass of native grasses in both 1978 and 1980 . Indian ricegrass, green needlegrass (stipa viridula), and big bluegrass (Poa compla) comprise a smaller proportion. Hard fescue (Festuca ovina duriuscula) and alkali sacaton (Sporobolus airoides), when first established, accounted for oniy a very minor component of total native grass density and biomass. However, later they showed some increase. Antelope bitterbrush experienced establ ishment difficulty and generally died out by 1980. Crested wheatgrass (Agropryon cristatum), Siberian wheatgrass (Agropyron sibericwom), pubescent wheatgrass (Agropyron trichophomm), intermediate wheatgrass, and Russian wildrye (Elymus junceus) showed little change in density and biomass from 1978 to 1980 . Alfaifa and cicer milkvetch (Astragalus cicer) still comprise the largest percentage of introduced forbs and made some increases from 1978 to 1980 . Yellow sweetclover (Melilotus officinalis) was a substantial biomass producer in 1978 but has since been decreasing rapidly. Small burnet (Sanguisorba minor) is often present but in low numbers and biomass. Bouncing bet (saponaria officinalis) established with low numbers and biomass in 1978 and has since largely died out.

Most seeded grass species under both fertilization and irrigation established greater numbers in 1978, but some decreases in number and biomass through 1979 and 1980 have been observed. Sweetvetch, globemallow, and Palmer penstemon (Penstemon palmeri) made small gains in biomass from 1978 to 1980 with the use of seeding Techniques 1 and 2 , but not with seeding Techniques 3 and 4 .

\section{Diversity}

Species diversity on revegetation plots were similar to diversity in undisturbed vegetation (Table 13). Irrigation gives a slight increase in diversity, but when discontinued this advantage diminishes with time. Although grass cover appears to die back on irrigated and fertilized plots to values approximating nonirrigated and nonfertilized conditions, grass densities still remain high. Fertilization depresses diversity without irrigation, and there is little change with time. There was a slight increase in diversity due to fertilization under irrigated conditions, but this decreases with the termination of irrigation. Techniques 3 and 4 , even without the third life form (shrubs), appear to produce greater diversity than do Techniques 1 and 2 . Species diversity was depressed in native and combination seed mixtures in Technqiues 1 and 2, particularly under nonirrigated 
conditions. This was due to competition and dominance from fourwing saltbush. The native seed mixture produced lower diversities than the combination seed mixture. The introduced seed mixture has had slightly higher diversities than the native mixture. This is due to the lack of shrubs and the increased grass and forb component of this mixture.

Table 13. Average native and seeded vegetation diversity indices as determined by the Shannon-Weiner Index.

\begin{tabular}{|c|c|c|c|}
\hline & 1978 & 1979 & 1980 \\
\hline $\begin{array}{l}\text { Native range } \\
\text { Revegetation }\end{array}$ & $\begin{array}{l}0.77 \\
0.77\end{array}$ & $\begin{array}{l}0.77 \\
0.76\end{array}$ & $\begin{array}{l}0.77 \\
0.74\end{array}$ \\
\hline $\begin{array}{l}\text { Irrigated } \\
\text { Nonirrigated }\end{array}$ & $\begin{array}{l}0.84 \\
0.70\end{array}$ & $\begin{array}{l}0.82 \\
0.71\end{array}$ & $\begin{array}{l}0.76 \\
0.72\end{array}$ \\
\hline $\begin{array}{l}\text { Fertilized, Nonirrigated } \\
\text { Nonfertilized, Nonirrigated } \\
\text { Fertilized, Irrigated } \\
\text { Nonfertilized, Irrigated }\end{array}$ & $\begin{array}{l}0.68 \\
0.73 \\
0.84 \\
0.83\end{array}$ & $\begin{array}{l}0.66 \\
0.76 \\
0.83 \\
0.81\end{array}$ & $\begin{array}{l}0.69 \\
0.75 \\
0.78 \\
0.74\end{array}$ \\
\hline $\begin{array}{l}\text { Technique } 1 \\
\text { Technique } 2 \\
\text { Technique } 3 \\
\text { Technique } 4\end{array}$ & $\begin{array}{l}0.74 \\
0.64 \\
0.84 \\
0.85\end{array}$ & $\begin{array}{l}0.72 \\
0.61 \\
0.88 \\
0.85\end{array}$ & $\begin{array}{l}0.72 \\
0.62 \\
0.81 \\
0.82\end{array}$ \\
\hline $\begin{array}{l}\text { Technique } 1 \text {, Nonirrigated } \\
\text { Combination seed mixture } \\
\text { Native seed mixture } \\
\text { Introduced seed mixture }\end{array}$ & $\begin{array}{l}0.65 \\
0.54 \\
0.80\end{array}$ & $\begin{array}{l}0.56 \\
0.38 \\
0.89\end{array}$ & $\begin{array}{l}0.55 \\
0.54 \\
0.86\end{array}$ \\
\hline $\begin{array}{l}\text { Technique } 2 \text {, Nonirrigated } \\
\text { Combination seed mixture } \\
\text { Native seed mixture } \\
\text { Introduced seed mixture }\end{array}$ & $\begin{array}{l}0.40 \\
0.27 \\
0.88\end{array}$ & $\begin{array}{l}0.42 \\
0.22 \\
0.88\end{array}$ & $\begin{array}{l}0.50 \\
0.36 \\
0.81\end{array}$ \\
\hline $\begin{array}{l}\text { Seed Mixture } \\
\text { Nonirrigated } \\
\text { Combination } \\
\text { Native } \\
\text { Introduced }\end{array}$ & $\begin{array}{l}0.65 \\
0.60 \\
0.86\end{array}$ & $\begin{array}{l}0.66 \\
0.84 \\
0.57\end{array}$ & $\begin{array}{l}0.71 \\
0.64 \\
0.82\end{array}$ \\
\hline $\begin{array}{l}\text { Irrigated } \\
\text { Combination } \\
\text { Native } \\
\text { Introduced }\end{array}$ & $\begin{array}{l}0.81 \\
0.71 \\
0.98\end{array}$ & $\begin{array}{l}0.81 \\
0.77 \\
0.89\end{array}$ & $\begin{array}{l}0.77 \\
0.72 \\
0.79\end{array}$ \\
\hline
\end{tabular}

\section{Conclusions}

Subsurface and surface rockiness appear to in-fluence the establishment and growth of grasses. and shrubs. Plots with greater rockiness promoted fourwing saltbush production and decreased grass production. Total production and species composition of the revegetated community appeared to be altered by rockiness in both the surface and subsurface profiles. A clearer explanation of the influence of rockiness cannot be offered at this time, but research is continuing.

Biomass, cover, and density of seeded grasses and forbs were greatest in the introduced seed mixture. Seeded shrubs in this mixture have had almost $100 \%$ mortality since seeding in 1976 . In general, the combination seed mixture of both native and introduced species was similar to the native seed mixture in terms of seeded species biomass, cover, and density. The combination seed mixture did however produce greater winterfat density, cover, and biomass than the native seed mixture. The combination seed mixture al so produced greater biomass with the use of seeding Techniques

$\mathcal{I}$ and 2. However, the native seed mixture produced greater biomass with the use of seeding Techniques 3 and 4 where shrubs were omitted. Fourwing saltbush densities were increased with the use of seeding Technique 2 where the rate of shrub seeding was increased and the rate of grass and forb seeding was decreased. Conversely, winterfat, grass, and forb biomass were favored by use of seeding Technique 1. Forb biomass was increased using Technique 4 (broadcast seeding with twice the rate) compared to Technique 3 . Grass biomass was increased with Technique 3 over Technique 4.

Fertilization increased the yield of fourwing saltbush on both irrigated and nonirrigated plots. Winterfat experienced decreased densities, cover, and biomass with fertilization under both irrigated and nonirrigated conditions. Forbs seeded with Techniques 1 and 2 did not respond to fertilization under nonirrigated conditions but did exhibit increased densities with fertilization under irrigated conditions. However, fertilization decreased biomass, cover, and density of forbs seeded with Techniques 3 and 4 under both irrigated and nonirrigated conditions. Fertilization, in most cases, increased biomass, cover, and density of grasses seeded with all techniques under both irrigated and nonirrigated conditions.

Irrigation enhanced grass establishment in 1977 and 1978, which in turn suppressed forbs and shrubs. However, in 1980 these irrigated grasses have now decreased to similar biomass and cover levels as those found in the nonirrigated piots. This has allowed the surviving shrubs and forbs to increase biomass somewhat in the irrigated plots. Shrub cover in irrigated plots was half that found in nonirrigated plots. This was believed to be a consequence of increased stimulus of grass growth as a result of irrigation and greater competition with shrubs. Shrub densities, however, were higher in irrigated plots compared to nonirrigated plots. The major objective of irrigation is to protect the establishing vegetation from the adversities of climate. The species in nonirrigated plots, al though slower to establish, survived the drought of 1976-1977 without this irrigation advantage.

\section{LITERATURE CITED}

Berg, W. A., S. D. Merrill, and D. J. Dollhof. 1979. Chapter 2: Soils and overburden analysis and sampling techniques. Pages 13-27 in User guide to soils; Mining and Reclamation in the West. U.S. For. Serv. Gen. Tech. Rep. INT -68 .

Bonham, C. D: 1974. Classifying grassland vegetation with a diversity index. J. Range Manage. $27: 240-243$. 
Brady, N. C. 1974. The nature and properties of soils, 8th ed. MacMillan Publishing Company, Inc., New York.

California Fertilizer Association. 1980. The western fertilizer handbook, 6th ed. Interstate Printers and Publishers, Inc., Danville, 111 .

Cook, C. Wayne. 1965. Plant and livestock responses to fertilized rangelands: Utah Agric. Exp. Stn. Bull. 455.

Cook, C. Wayne, and Edward F. Redente, princ. invest. 1980. Reclamation studies on 0 ir shale lands in northwestern Colorado. Progress report for U.S. Dep. Energy. DE-AS02-76EV04018. (Dep. Range Sci., Colo. State Univ., Ft. Collins.) $58 \mathrm{p}$.

Cook, C. W., L. A. Stoddart, and P. L. Sims. 1967. Effects of season, spacing and intensity of seeding on the development of foothill range grass stands. Utah Agric. Exp. Stn. Bul1. 467.

Cosper, H. R., J. R. Thomas, and A. Y. Alsayegh. 1967. Fertilization and its effect on range improvement in the Northern Great Plains. J. Range Manage. 20:216-222.

Evans, R. A., and J. A. Young. 1972. Microsite requirements for establ ishment of annual rangeland weeds. Weed Sci. 20:350-356.

Hillel, D., and N. Tadmore. 1962. Water regime and vegetation in the Central Negev Highlands of Israel. Ecology $43: 33-41$.

Klein, Donald A., Larry E. Hersman, Nicholas Nagle, Darwin L. Sorensen, and Shen-yuh Wu. 1980. Pages 27-41 in C. Wayne Cook and Edward F. Redente, princ. invest. Reclamation studies on oil shale lands in northwestern Colorado. Progress report for U.S. Dep. Energy. DE-AS0276EV04018. (Dep. Range Sci., Colo. State Univ., Ft. Collins.) $58 \mathrm{p}$.

McDonough, W. T. 1977. Seed physiology. Pages 155-184 in R. E. Sosebee, ed. Rangel and plant physiology. Soc. Range Manage., Denver, Colo.

Miltimore, J. E., and J. L. Mason. 1981. Copper to molybdenum ratio and molybdenum and copper concentrates in ruminant feeds. Can. J. Anim. Sci. $57: 193-200$.

Redente, Edward F., Walter J. Ruzzo, Carolyn E. Grygiel, Ronald F. Jepson, and Carl B. Mount. 1980. Effect of plant species, soil material, and cultural practices upon plant establishment and succession. Pages 1-17 in C. Wayne Cook and Edward F. Redente, princ. invest. Reclamation studies on oil shale lands in northwestern Colorado. Progress report for U.S. Dep. Energy. DE-AS02-76EV04018. (Dep. Range Sci., Colo. State Univ., Ft. Co.lins.) 58 p.

Reeves, F. Brent, Jr. 1980. Importance of mycorrhizal fungi in revegetating disturbed soils and retorted shale. Pages 35-41 in C. Wayne Cook and Edward F. Redente, princ. invest. Reclamation studies on oil shale lands in northwestern Colorado. Progress report of U.S.
Dep. Energy. DE-ASO2-76EV04018. (Dep. Range Sci., Colo. State Univ., Ft. Collins.) $58 \mathrm{p}$.

Ries, R. E., F. M. Sandoval, J. F. Power, and W. 0. Willis. 1976. Perennial forage species response to sodium and magnesium sulfate in mine spoil. Pages 173-183 in National Coal Assoc. Bituminous Coal Research Inc. Fourth Symposium on Surface Mining and Reclamation, 19-21 oct., Louisville, $\mathrm{Ky}$.

Sandoval, F. M., and W. L. Gould. 1978. Improvement of saline- and sodium-affected disturbed lands. Pages 485-504 in F. W. Schaller and P. Sutton, eds. Reclamation of drastically disturbed lands. ASA, CSSA, SSSA, Madison, Wis.

Schwab, A. P., W. L. Lindsay, and G. P. Marx. 1980. Uptake of chemical elements by plants growing on spent shale. Pages 85-112 in W. R. Chappell, princ. invest. Trace elements in oil shale. Progress report (1979-1980) for U.S. Dep. Energy. EV-10298.

Shannon, C. E., and $W$. Weaver. 1973. The mathematical theory of communication. Univ. of Illinois Press, Urbana. $117 \mathrm{p}$.

Sindelar, B. H., and P. L. Plantenberg. 1978. Establishment, succession and stability of vegetation on surface mined lands in eastern Montana. Annual progress report. Mont. Agric. Exp. Stn., Mont. State Univ., Bozeman.

Striffler, W. D., I. F. Wymore, and.W. A. Berg. 1974. Characteristics of spent shale which influence water quality, sedimentation, and plant growth medium. In C. W. Cook, ed. Surface rehabilitation of land disturbances resulting from oil shale development. Colo. State Univ., Environ. Resour. Cent., Tech. Ser. 1, Ft. Collins.

Thorup, J. T. 1969. pH effect on root growth and water uptake by plants. Agron. J. 61:225-227.

Tisdale, S. L., and W. L. Nelson. 1975. Soil fertility and fertilizers, 3rd ed. MacMillan Publishing Company, Inc., New York.

Vallentine, J. F. 1977. Chapter 10: Range fertilization. Pages 327-370 in Range development and improvements. Brigham Young Univ. Press., Provo, Utah.

Weaver, John E., and Frederic E. Clements. 1938. Plant ecology. McGraw-Hill Book Company, Inc. New York.

Wight, J. R., and A. L. Black. 1978. Soil water use and recharge in a fertilized mixed prairie plant community. J. Range Manage. 31:280-282.

Woodmansee, R. G., J. D. Reeder, and W. A. Berg. 1978. Nitrogen in drastically disturbed 1 ands. In Forest soils and land use. Proc., Fifth North American Soils Conf., Colo. State Univ., Ft. Collins. 
AVAILABLE PUBLICATIONS AND/OR ABSTRACTS

Sims, Phillip L., and Edward F. Redente. 1977. Rehabilitation potential and practices of Colorado oil shale lands. Second Pacific Chemical Engineering Congress Proceedings.

Koehler, David A., and Edward F. Redente. 1979. Revegetation techniques on disturbed lands associated with oil shale development. Society for Range Management Annual Meeting, Casper, Wyo. (Abstr.)

Redente, Edward F., and Walter J. Ruzzo. 1979. Topsoiling of retorted oil shale. Pages 285291 in Stanley B. Carpenter, ed. Proceedings, Symposium on Surface Mining Hydrology, Sedimentology, and Reclamation. Univ. Kentucky, Lexington, 4-7 December.

Redente, Edward F., and Walter J. Ruzzo. 1979. Eariy plant succession on simulated oil shale disturbances. Society for Range Management Annual Meeting, Casper, Wyo. (Abstr.)

Johnson, Douglas E., and Edward F. Redente. '1979. Plant succession on disturbed lands associated with oil shale development as affected by species mixtures, fertilizer, and mulch. Society for Range Management Annual Meeting, Casper, Wyo. (Abstr.)

Redente, E. F., D. A. Klein, and W. J. Ruzzo. 1979. Effects of reclamation techniques on successional processes. American Society of Agronomy Annual Meeting, fort Collins, Colo. (Abstr.)

Cook, C. W., E. F: Redente, and W. J. Ruzzo. 1980. Retorted oil shale management. Second U.S. Department of Energy Environmental Control Symposium, Reston, Va.

Ruzzo, Walter J., and Edward F. Redente. 1980. Plant succession on simulated oil shale disturbances. Society for Range Management Annual Meeting, San Diego, Calif. (Abstr.)

Jepson, Ronald F., and Edward F. Redente. 1980 Cultural practices and the ir ability to aid in the revegetation of intensively disturbed sagebrush-bunchgrass communities. Society for Range Management Annual Meeting, San Diego, Calif... (Abstr.)

Redente, E. F. … J. Ruzzo, C." Wayne Cook, and W. A. Berg. 1980. Retorted oil shale characteristics and reclamation. U.S. Dep. Energy Monograph. In press.

Redente, E. F., W. J. Ruzzo, and C. Wayne Cook. 1980. Plant succession on oil shale disturbed lands. ESA/AIBS Symposium, Tucson, Ariz. In press.

Redente, Edward F. 1980. Sweetvetch seed germination. J. Range Manage. Submitted October.

Redente, Edward F., and F. Brent Reeves. Interaction between a vesicular arbuscular mycorrhiza and Rhizobium and their effect on
Hedysamum boreale. Soil Sci. Accepted for publication.

C. Wayne Cook, and Edward F. Redente. 1981. Difficulty of seeding shrubs in mined lands. Society for Range Management Annual Meeting, Tulsa, Okla. (Abstr.)

Fulbright, Timothy F., and Edward F. Redente. 1981. Germination requirements of green needlegrass (Stipa vimiduza Trin.). Society for Range Management Annual Meeting, Tulsa, Okla. (Abstr.)

Grygiel, Carolyn E., and Edward F. Redente. 1981. Secondary succession on surface disturbed soils in northwestern Colorado. Society for Range Management Annual Meeting, Tulsa, Okla. (Abstr.)

Sievers, Thomas E., and Edward F. Redente. 1981. Revegetation techniques on intensively disturbed soils in northwestern Colorado. Society for Range Management Annual Meeting, Tulsa, 0kla. (Abstr.)

Doerr, Ted B., Edward F. Redente, and F. Brent Reeves. 1981. Relationships between mycorrhizal fungi and plant community succession. Society for Range Management Annual Meeting, Tulsa, Okla. (Abstr.)

Mount, Carl B., and Edward F. Redente. 1981. Stabilization and revegetation of retorted oil shale. Society for Range Management Annual Meeting, Tulsa, Okla. (Abstr.)

Doerr, T. B., E. Sievers, and E. F. Redente. 1981. Methods for establishment of diverse native and introduced plant communities on disturbed soils. Reclam. Rev. Submitted February.

Doerr, T. B., E. F. Redente, and F. B. Reeves. 1981. Natural plant succession and mycorrhizal fungi relationship on disturbed sagebrush soils. Am. J. Bot. Submitted February.

Mount, Carl B., Walter J. Ruzzo, and Edward F. Redente. 1981. Reclamation and stabilization of retorted oil shale. Reclam. Rev. Submitted Feburary.

Vories, Kimery C. 1981. Growing Colorado plants from seed: A state of the art. I. Shrubs. U.S. For. Serv., Intermt. For. Range Exp. Stn.

Fulbright, Timothy $F$., and Edward F. Redente. 1981. Growing Colorado plants from seed: A state of the art. II. Grasses. U.S. Dep. Interior, Biolog. Serv. Prog., Fish Wildl. Serv. Accepted for publication.

Redente, Edward F., Phillip Ogle, and Norman Hargis. 1981. Growing Colorado plants from seed: A state of the art. III. Forbs. U.S. Dep. Interior, Biolog. Serv. Prog., Fish Wildi. Serv. In preparation. 


\section{SOIL MICROORGANISMS AND METHODS OF RETORTED SHALE RECLAMATION}

Donald A. Klein, Darwin L. Sorensen, and Marcia. Brokish

Department of Microbiology

Colorado State University

Fort Collins, Colorado 80523

\section{OBJECTIVES}

Over the last five years, the effects of soil distubance and retorted oil. shale on the development of soil microbial processes have been monitored in relation to seeding mixture, fertilization, irrigation, and seeding technique variables. Specific objectives have included the following:

1. To evaluate microbial responses during reestablishment of plant communities on disturbed and revegetated soils using plots established at the Intensive Study Site

2. To study the effects of soil storage on microbiological populations and on microorganism- related nutrient cycling processes

3. To determine the effects of retorted shale materials on the microbiological characteristics of surface soils from the study site in relation to the development of plant communities on these materials.

\section{METHODS}

Study Site

For most of the sampling carried out as a part of this study, samples were taken from the Intensive Study site. These included samples from the various test plots and reference samples from adjacent control areas.

\section{Soil Sampling}

From each subplot three samples were taken, at each of the ends and in the center of the rectangular areas. The soil samples were taken from the 0-5 cm depth to assure that effects of shorter-term variations in temperature and moisture would be minimized and to sample from the zone where maximum plant root development would occur. Also, no aboveground materials or soils directly adjacent to plants were taken in order to mainta in the experimental integrity of the plots. Samples were sieved through a $2 \mathrm{~mm}$ mesh screen, mixed in a PattersonKelly twin shell dry blender for 20 minutes, returned to individual plastic bags, and stored at $6{ }^{\circ} \mathrm{C}$ until analysis or use in experiments.

\section{General Analytical Procedures}

The procedures for soil organic matter measurement, microbial enumeration, nitrogen fixation, phosphatase and dehydrogenase activities, and soil ATP have been described by Hersman and Kiein (1979) and Sorensen et al. (1981). The procedure for radioactive glucose mineralization has been described by Nakas and Klein (1980).

\section{Plant-Associated Nitrogen Fixation Potential}

\section{Laboratory Studies}

These procedures have been described in the 1979 progress report.

\section{Field Studies}

To assess the relative nitrogen fixation activity of legume species growing at the Intensive Site in plots described by Sabey et al. on page 57 of this report, nodule acetylene reduction activities were measured. Representative plants were selected from subsoil and topsoil plots fertilized with 0,56 , or $112 \mathrm{~kg} \mathrm{~N} / \mathrm{ha}$. The legume species studied were sweetvetch (Hedysamon boreale), cicer milkvetch (Astragalus cicer), and Ladak alfalfa (Medicago sativa). The effect of seedbed inoculation with soil previously exposed to growth of specific legumes and/or growth with native grasses on acetylene reduction activity of sweetvetch nodulated roots was evaluated in addition to the effects of soil type and fertilization.

$\because$ For sampling carried out on June 10, 11 , and 12, 1980, a soil cylinder of $30 \mathrm{~cm}$ in diameter and 20 to $30 \mathrm{~cm}$ deep was taken containing the selected plant. The excavated soil and plant(s) were placed in an 18-7iter container of local well water for up to 60 minutes. When the soil had become saturated, it was gently separated from the roots to avoid tearing the nodules from the roots. After washing 
the root material and nodules were placed in a wide-mouthed, quart $(980 \mathrm{ml})$ mason jar with a few milliliters of water and closed with a lid containing a serum bottle septum. The closed jars were immediately buried in the soil with only the tops exposed. They were then shaded with aluminum foil. With this procedure the jars remained at $19 \pm 0.5^{\circ} \mathrm{C}$

The closed jars were incubated for 45 to 60 minutes (exact incubation times were recorded) after which the atmosphere was sampled using a $10 \mathrm{ml}$ evacuated blood sampling tube. This initial sample was used as a check for ethylene production by the roots without added acetylene. After this sample was taken, approximately $88 \mathrm{ml}$ of gas were removed from the jar atmosphere with a hypodermic syringe (i.e., $98 \mathrm{ml}$, or $0.1 \mathrm{~atm}$, total volume including the $10 \mathrm{ml}$ removed with the initial sample). Then, $98 \mathrm{ml}$ of sulfuric acid-scrubbed acetylene was injected, the time was recorded, and the incubation was continued for about one hour. A final sample of the jar atmosphere was taken with a $10 \mathrm{mi}$ evacuated blood tube, and the time was again recorded.

The gas samples in the blood tubes were analyzed for acetylene and ethylene, and the acetylene content was used as an internal standard. Adjustments for atmospheric pressure changes due to elevation changes were also made.

The roots were then placed in a plastic bag and kept on ice until they were returned to the laboratory where they were kept frozen at $-20^{\circ} \mathrm{C}$. The roots and nodules were then dried separately in tared containers at $75^{\circ} \mathrm{C}$ for 48 hours and then at $105^{\circ} \mathrm{C}$ for 2 hours. A ratio of dry weight of nodules $(\mathrm{mg})$ to dry weight of roots $(\mathrm{g})$ (i.e., a nodulation frequency) was then calculated,..as well as the amount of acetylene reduced per milligram of dry weight of nodules.

\section{Shale Extraction Experiments}

Soils were mixed with retorted shale which had been exposed to methylene chloride for 48 hours, followed by washing for 24 hours with methyl alcohol and washing for 24 hours with double distilled sterile water. This was completed to determine whether the organic or inorganic fraction of retorted shale might be responsible for the previousiy reported effects of retorted shale on microbial activities.

\section{Nitrification Activity Measurements}

Nitrification activity has been monitored using two approaches. In the first studies, $50 \mathrm{gm}$ portions of the test soils were added to four petri plates to give three replicates and a control. To the three experimental soil samples, $10 \mathrm{ml}$ of ammonium sulfate solution $\left(0.5 \mathrm{~g} \mathrm{~K}_{2} \mathrm{HPO}_{4}, 5 \mathrm{~g}\right.$ $\left(\mathrm{NH}_{4}\right)_{2} \mathrm{~S}_{4}, 100 \mathrm{ml} \mathrm{H}$ ) were added to the soil using a syringe to cover the entire surface of the plate. The plate was covered and placed in a sealed incubator at room temperature which was kept humid by a tray of water. At two-week intervals, $14 \mathrm{~g} \mathrm{soil}$ al iquots. were air dried and analyzed for nitrate using the Orion nitrate electrode (Model 93-07) and Orion reference electrode (Model 90-02) connected to a Corning $\mathrm{pH} / \mathrm{mv}$ meter. The soil sample was emptied into a flask to which was added $50 \mathrm{ml} \mathrm{H}_{2} \mathrm{O}$, $0.5 \mathrm{ml} \mathrm{AgF}, 0.5 \mathrm{ml}$ of concentrated acetic acid, and $1 \mathrm{~g} \mathrm{CaOH}$. The flask was shaken on a reciprocal shaker at $125 \mathrm{rpm}$ for 30 minutes and filtered through whatman \#1 filter paper. The nitrate electrode was lowered into the filtrate, and millivolts were recorded and read against a nitrate standard curve.

Secondly, the chlorate ion block procedure of Belser and Mays (1980) has been evaluated and refined to allow rapid evaluation of the potential activity of autotrophic ammonium oxidizers and nitrate oxidizers in these lower activity soils.

Ammonium Ion Effects on Nitrogen Fixation in Soil-Shale Mixtures

Soil from the revegetation plot samples 1-121-A, B, C and 1-122-A, B, C (sampled on May 25, 1979) were mixed together. This soil was then mixed with shale into ratios of $90 \%$ soil-10\% shale and $75 \%$ soil-25\% shale. In addition, the shale was used alone. The shale was passed through a 32-mesh sieve before use. Ammonium ion was added as ammonium chloride.

The soil water holding capacity was'determined using the procedure of Peters (1965) as modified by Sherwood (1979). For most experiments, if the soils were at an appropriate soil water level, the soils were simply amended with a $0.5 \% \mathrm{w} / \mathrm{v}$ glucose solution. The solutions of glucose at $0.5 \% \mathrm{w} / \mathrm{v}$ were made up to give final ammonium ion nitrogen levels of 0,50 , and $200 \mu \mathrm{g} / \mathrm{g}$ soil. The acetylene reduction values were determined as described previously.

\section{Ammonia Volatilization}

The loss of gaseous ammonia from revegetated soils was studied under laboratory conditions using unfertilized soils from the Retorted Shale Successional study plots seeded with native plants. A sample was composited from soil $30 \mathrm{~cm}$ deep over spent shale, from soil $61 \mathrm{~cm}$ deep separated from spent shale by a $30 \mathrm{~cm}$ gravel capillary barrier, and from control soil (soil not over spent shale). Three subsamples of this composited and air dried soil were saturated with deionized water, a solution of $100 \mathrm{mg} \mathrm{NH}+\mathrm{N} / \mathrm{l}$, and a solution of $375 \mathrm{mg}$ $\mathrm{NH}_{4}-\mathrm{N} / 1$ (respectively) and were prepared from $\left(\mathrm{NH}_{4}\right)_{2} \mathrm{SO}_{4}$. The three saturated soils were quickly brought to approximate field capacity $(22.7 \pm 0.3 \%$ moisture by weight) by centrifuging at $1000 \times \mathrm{g}$ for 30 minutes. This procedure assures rapid, even distribution of the treatment solution through the soil. The soil treated with $100 \mathrm{mg} \mathrm{N} / 1$ received about $22 \mathrm{mg} \mathrm{N} / \mathrm{g}$ dry weight; the soil treated with $375 \mathrm{mg} \mathrm{N} / 1$ received about $84 \mathrm{mg} \mathrm{N} / \mathrm{g}$ dry weight. Initial $\mathrm{KCl}$ extractable $\mathrm{NH}_{4}^{+}-\mathrm{N}$ from the soils was $15.7 \pm 1.1 \mu \mathrm{g} / \mathrm{g}$ and $66.9 \pm 7.8 \mathrm{\mu g} / \mathrm{g}$, respectively. 
Triplicate samples of approximately $100 \mathrm{~g}$ of moist soil (after taring) were incorporated into gas scrubbing trains. Approximately $100 \mathrm{ml} / \mathrm{min}$ of water saturated air were drawn through each of the flasks and scrubbed through secondary $\mathrm{H}_{2} \mathrm{SO}_{4}$ traps as controls. Any weight loss was compensated for by adding deionized water--1ess than $10 \mathrm{ml}$ of water were added to any flask during the 34-day experiment.

Each of the treated soils was analyzed in triplicate immediately after treatment and at the end of the experiment for $\mathrm{KCl}$ extractable $\mathrm{NH}_{4}^{+}-\mathrm{N}$ in I $\mathrm{N} \mathrm{KCl}$ soil extracts. Nitrate-nitrogen was determined using diazotization colorimetry (Strickland and Parson 1968). Analys is for $\mathrm{NO}_{3}^{-}-\mathrm{N}$ was done using chromotropic acid colorimetry (APHA 1975). So il $\mathrm{pH}$ was also measured following treatment and at the conclusion of the experiment using $50 \%(\mathrm{w} / \mathrm{v})$ slurries, a glass combination electrode, and $\mathrm{pH}$ meter.

\section{Statistical Analysis}

All data were analyzed by standard statistical procedures. This included analysis of variance and regression analysis using available SPSS computer programs.

\section{RESULTS}

\section{Revegetation Techniques Plot}

Over the four years during which this plot at the Intensive Study Site has been monitored, marked changes in microbial activity have been observed with the development of the soil-plant system.

After one growing season, the Revegetation Techniques plot showed correlations which indicated that the system was responding to the planting mixture variables as measured by microbiological parameters (Table 14).

These initial Pearson correlations indicated that there were strong relationships between the soil organic matter levels, moisture availability, and more general microbial activity parameters especially in relation to the planting mixtures which had been used.

Although not significant, interesting trends were noted for the changes in soil organic matter in relation to treatments and planting mixture variables which suggested that there was a relationship between the presence of the introduced planting mixture and the soil organic carbon content responses. After one season the dehydrogenase activity showed particular trends in relation to fertilizer and previous soil treatment methods; however, an interesting relationship was shown between the presence of the introduced plant mixture and the soil dehydrogenase activity (Figure 29). This would suggest that the introduced species are able to fix more carbon for transport to the belowground compartment during initial growth on the
Table 14. Significant Pearson correlations for the Revegetation Techniques plot.

\begin{tabular}{|c|c|c|}
\hline Parameter & $\begin{array}{l}\text { Correlated } \\
\text { Parameters }\end{array}$ & $\begin{array}{c}\text { Signifi- } \\
\text { cance } \\
\text { Levels } \\
(\%)\end{array}$ \\
\hline Irrigation & $\begin{array}{l}\text { Dehydrogenase } \\
\text { Moisture content } \\
\text { Organic matter }\end{array}$ & $\begin{array}{l}1 \\
1 \\
1\end{array}$ \\
\hline Method & Dehydrogenase & $5^{.}$ \\
\hline Phosphatase & Dehydrogenase & 5 \\
\hline Dehydrogenase & $\begin{array}{l}\text { Irrigation } \\
\text { Method } \\
\text { Phosphatase } \\
\text { Percent moisture } \\
\text { Organic matter }\end{array}$ & $\begin{array}{l}1 \\
5 \\
5 \\
1 \\
1\end{array}$ \\
\hline Organic matter & Percent moisture & 1 \\
\hline
\end{tabular}

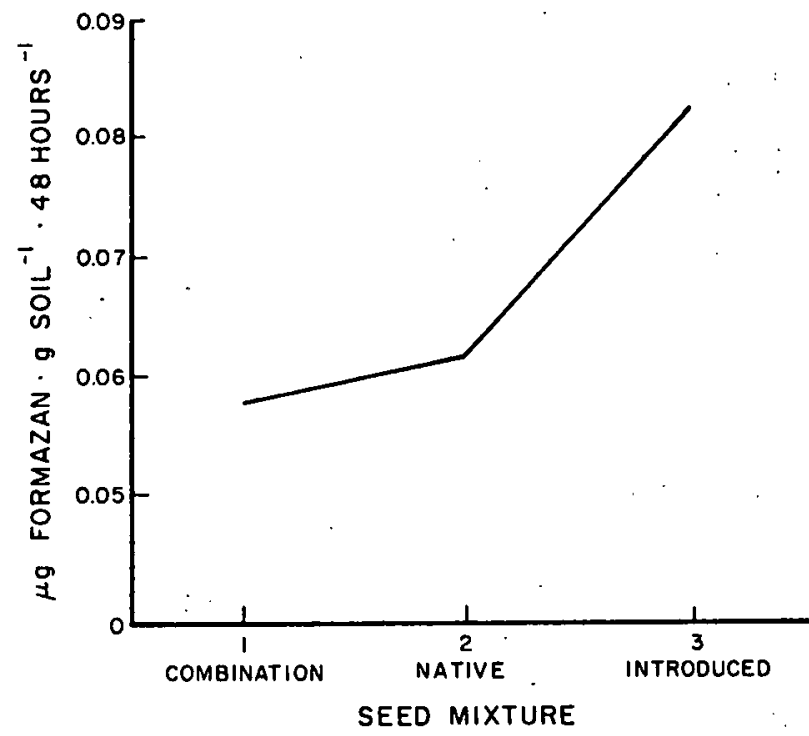

Figure 29. Effect of planting method (seed mixture on soil dehydrogenase activity) Revegetation Techniques plot--1977.

disturbed soil, an observation which was also supported by the organic matter analyses of the soil.

Irrigation, seeding method, seed mixture, and fertilizer level showed significant effects (single and interactive) on soil microbiological processes by the 1978 sampling. For both the May and July samplings, strong overall direct correlations were shown between the percentage soil organic matter and $\mathrm{pH}$ (inverse), soil water, dehydrogenase, phosphatase activity, $\mathrm{N}_{2}$ fixation potential, and soil ATP which appeared to be related to plant growth and subsequent organic matter release to the soil. With irrigation the native seed mixture showed the 
highest levels of soil organic matter; without irrigation the introduced species mixture was related to the highest organic matter content in the test soils (Figure 30 ). This would suggest that different seed mixtures may be appropriate for use in irrigated versus nonirrigated revegetation programs if belowground production is a concern. In addition, a trend towards decreased $\mathrm{N}_{2}$ fixation potential with fertilizer nitrogen additions was noted in comparison with the nonfertilized plots for the spring sampling (at a significance level of $p<.06)$. Irrigation had significant independent effects upon soil pH, dehydrogenase and phosphatase activities, and ATP and organic matter levels in the surface soils. As irrigation did not begin until after the May sampling, irrigation did not share a relationship with the soil water content. These results indicate that the irrigation effect on these microbiological parameters resulted from the previous year's irrigation activity. In 1977 the native plant species mixture appeared to produce more soil organic matter with irrigation, while with irrigation, the introduced plant species mixture produced better organic matter accumulation in the upper surface soil layer.

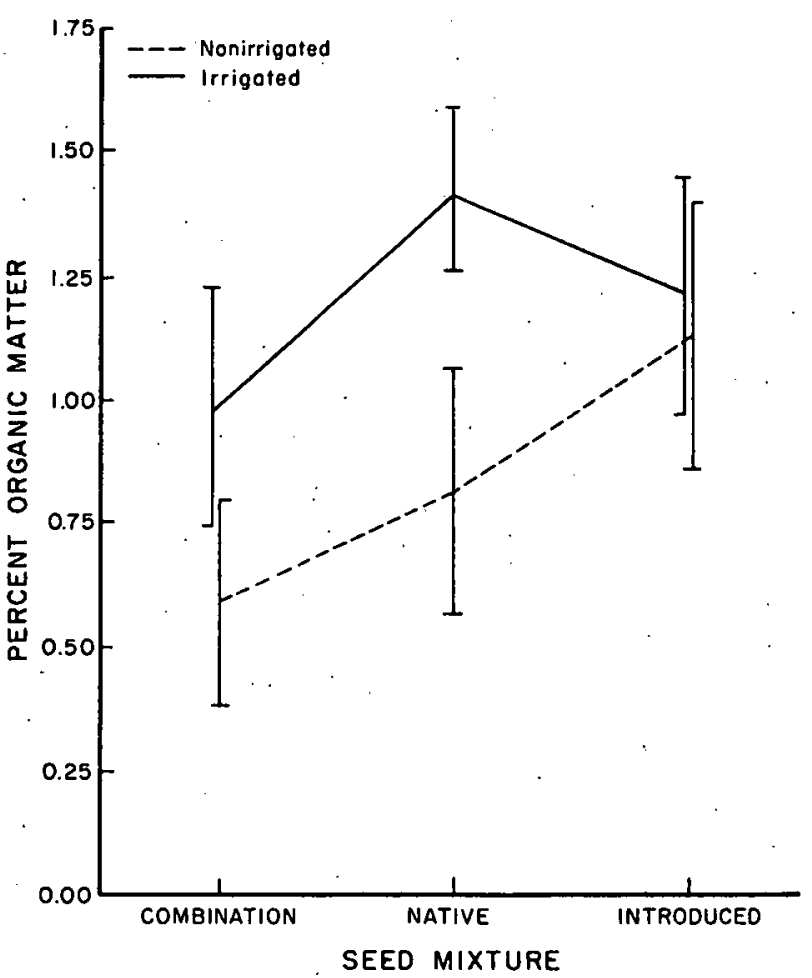

Figure 30. Irrigation and seed mixture effects on surface soil organic matter levels for the Revegetation Techniques plot--July 1978. (Standard deviations are shown.)

Dehydrogenase and phosphatase responses gave similar results for both the May and July samplings. For the spring sampling (May), fertilization was related to decreased phosphatase activity $(p<.065)$. This was not observed for the July sampling. A trend (still nonsignificant) towards decreased nitrogen fixation on the fertilized plots was also noted for the May sampling.

By 1979 strong correlations between the surface soil organic matter levels and other parameters were noted. Significant interactions of irrigation with dehydrogenase activity, $\mathrm{N}_{2}$ fixation, phosphatase and organic matter were observed, as had occurred in earlier years. Other interactions included species used with phosphatase and soil organic matter and a species-irrigation interaction.

Significant effects of irrigation $(p<.01)$ and fertilization ( $p<.02$ ) on nitrogen fixation potential were indicated when the combined 1978 and 1979 data were analyzed.

The species used also affected the nitrogen fixation potential, independent of irrigation and fertilizer variables: For the combined 1978 and 1979 years, the introduced species (Mixture 3 ) had a higher $\mathrm{N}_{2}$ fixation potential than the native or combination seed mixtures. This was significant at the $.074 \%$ level and indicates a trend which may become more profound in the coming season.

In a similar manner, the soil phosphatase activities were strongly influenced by the species used $(p<.01)$, with the introduced species showing the highest activities. With irrigation higher relative responses were also observed, and fertilization caused slight decreases in phosphatase activity.

Controls, which were taken across all test plots outside the zones where plant growth had taken place, did not indicate that significant differences in soil organic matter levels were initially present across the test plots.

For the 1980 season only a limited sampling of the Revegetation Technqiues plot was completed. As noted in earlier years, the effects of irrigation (even when carried out only in the first fall and spring following seeding) appears to have lead to significant increases in the surface soil organic matter levels and in the dehydrogenase and phosphatase activities.

\section{Long-Term Fertility Plots}

The fertility plots at the Intensive Study Site were analyzed during the 1979 season but not in 1980. These plots and their various treatments are described by Sabey et al. in this report. Data on microbial activity were presented in the 1980 progress report.

\section{Successional Plot}

The Surface Disturbed Successional plot was analyzed in both 1978 and 1979 but not in 1980 . Reference to data collected and discussed appears in the 1980 progress report. 


\section{Annual Disturbance Plots}

In the initial correlation of general microbiological measurements across the four treatments and the disturbance years 1976 and 1977 , a series of significant relationships of disturbance and microbial activity were noted (see 1978 progress report).

\section{Retorted Shale Successional Plot}

The Retorted Shale Successional plot, which was initiated in 1978 and sampled during 1979 and 1980, provided the first direct information concerning possible effects of retorted shale on the microbiological characteristics of revegetated soils placed over this material and concerning capillary barrier performance under field conditions.

Major conclusions drawn from this study include the following:

1. With direct contact of oil shale under surface soil at various depths, similar decreases in microbial activity are noted which appear to give an early indication of similar subsequent decreased plant community responses (see Redente et al. of this report).

2. A capillary barrier, as used in this experiment, appears to provide only shortterm (one to two year) protection of surface soil from the effects of underlying retorted shale.

3. Retorted shale without surface soil treatments had negligible microbial activity at the beginning of the experiment and also after a three-year period.

The major relationship noted for this experiment was the nearness of retorted shale to the surface soil as it affects microbial activity. No species or fertilizer effects were observed in 1979 although a fertilizer-planting mixture interactive effect on nitrogen fixation was noted. This information is presented in the 1980 progress report.

The major 1980 observation was that the capillary barrier plot surface solls, instead of being similar to the control soils as observed in 1979, had relatively lower microbial activities which were more like soils place directly over retorted shale materials. This was most evident for the surface soil dehydrogenase activity where the soils with and without the capillary barrier had similar activities, all of which were lower than the controls. The dehydrogenase assay with added glucose less control values gave the clearest differences (Figure 31) while dehydrogenase assay without added glucose gave similar but less clear-cut results (Figure 32 ). Under these conditions the $91 \mathrm{~cm}$ soil depth was not significantly different from the control soil, while the capillary barrier still showed a significant decreased activity.

Similar decreased activity of all panels in comparison with the control were shown for

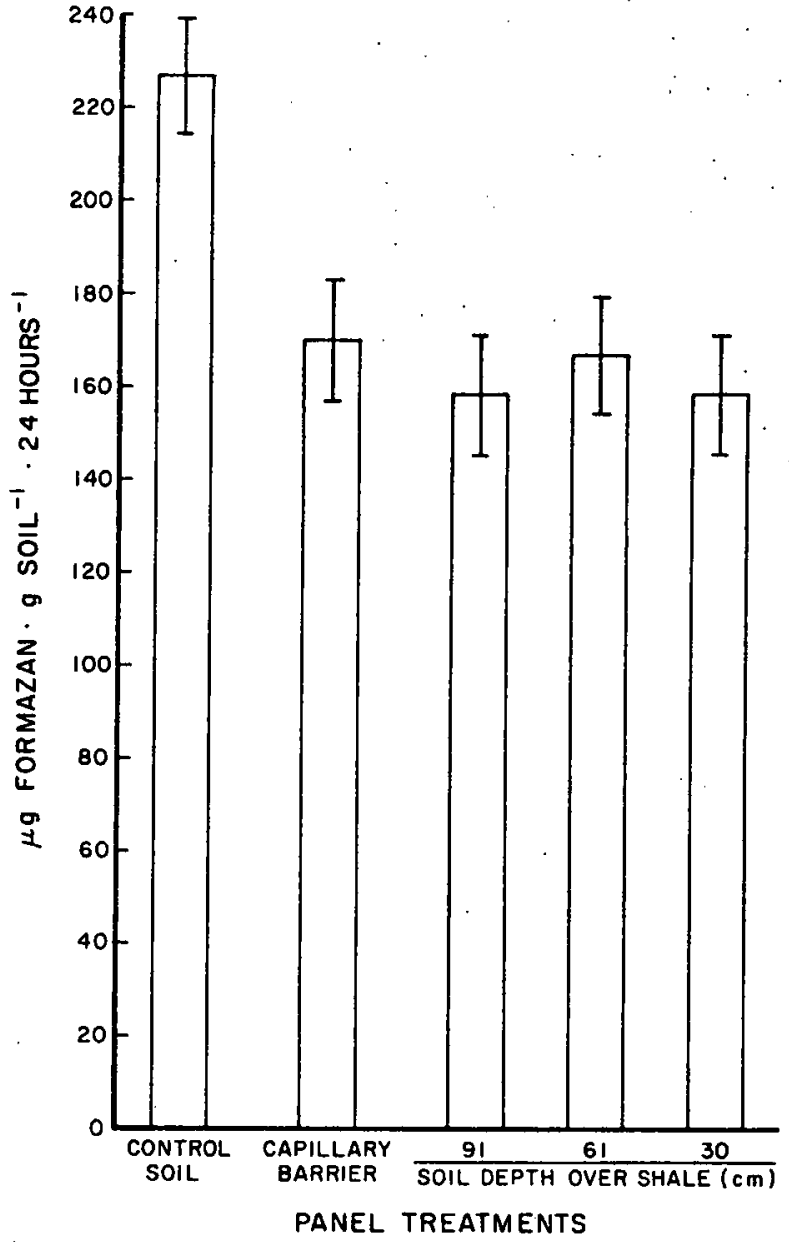

Figure 31. Effects of soil depth and a capillary barrier on the dehydrogenase activity (glucose-treated less control) of revegetated soil located over retorted shale--1980. (The least significant difference range ( $p \leq .05)$ is given.)

phosphatase (Figure 33) and nitrogen fixation potential (Figure 34), with the nitrogen potential responses being most distinct. For the soil organic matter, the control and $91 \mathrm{~cm}$ surface soil over shale had similar levels while the capillary barrier soils were higher and the 30 and $61 \mathrm{~cm}$ soil depths over the retorted shale were significantly lower (Figure 35).

In 1980 and as noted in 1979, there was an increased $\mathrm{N}_{2}$ fixation potential with the high fertilizer treatment, although this was not significantly different from the control (Figure 36).

For the 1980 season an attempt was made to measure microbial activities at various soil depths as well as analyzing the $5-10 \mathrm{~cm}$ surface soil samples. When averaged over depth to shale, capillary barrier soils had activities equal to or higher than the controls while soils directly over shales were more similar to controls. It was of particular interest to note that the capillary 


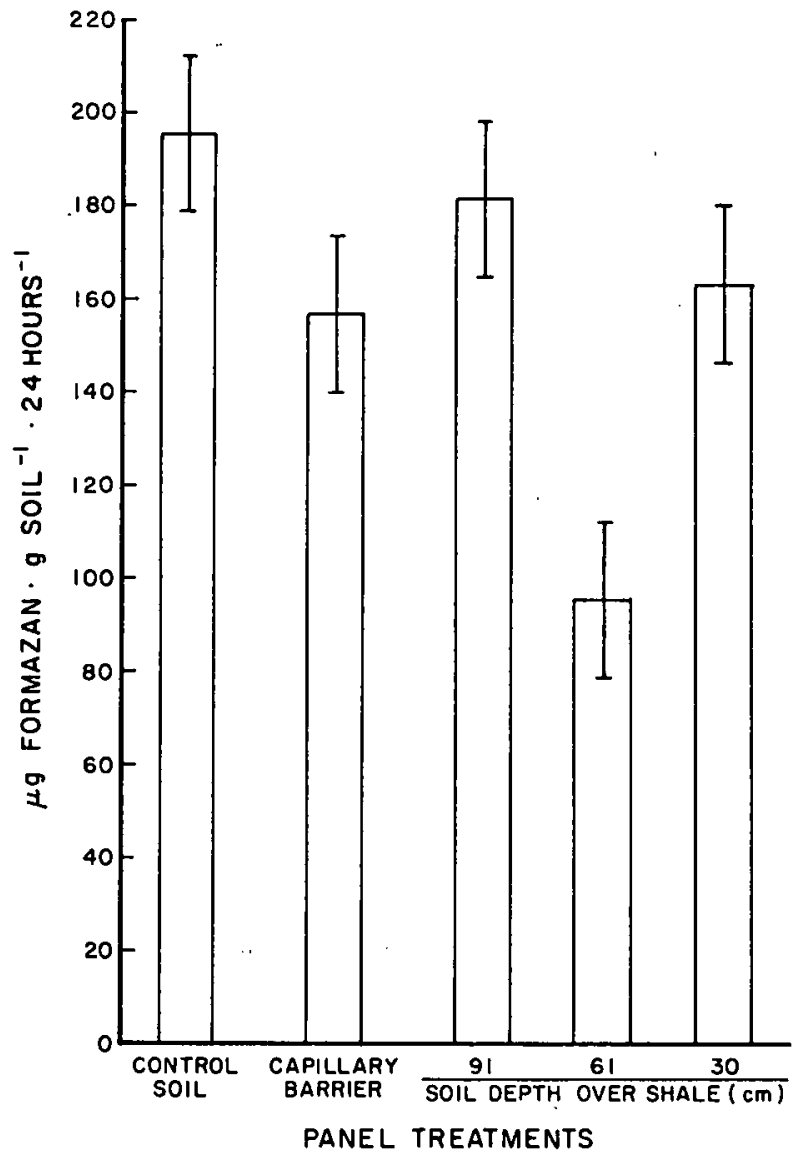

Figure 32. Effects of soil depth and a capillary barrier on the dehydrogenase activity (without glucose amendment) of revegetated soil located over retorted shale-1980. (The least significant difference range ( $p \leq .05)$ is given.)

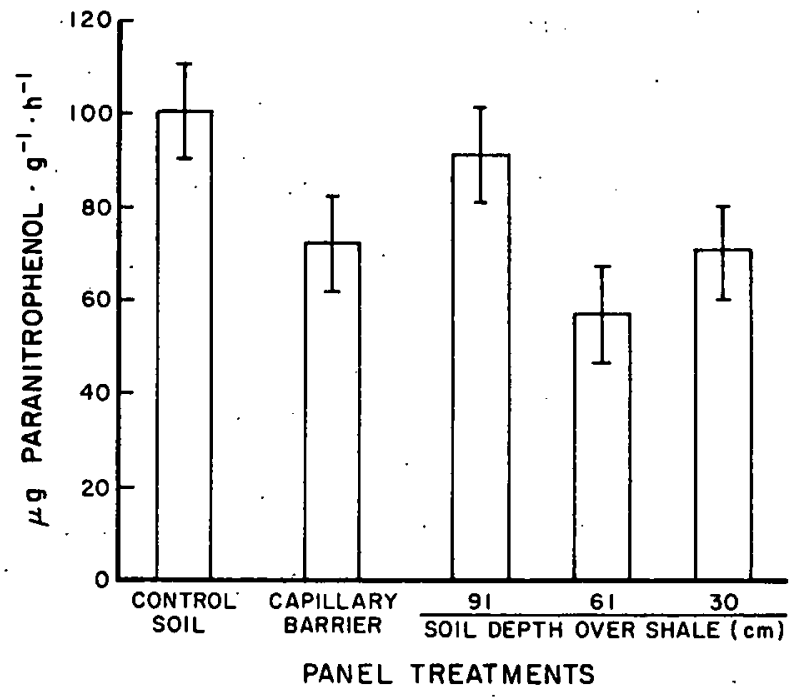

Figure 33. Effects of soil depth and a capillary barrier on the phosphatase activity of revegetated soil located over retorted shale--1980. (The least significant difference range ( $p \leq .05)$ is given.)

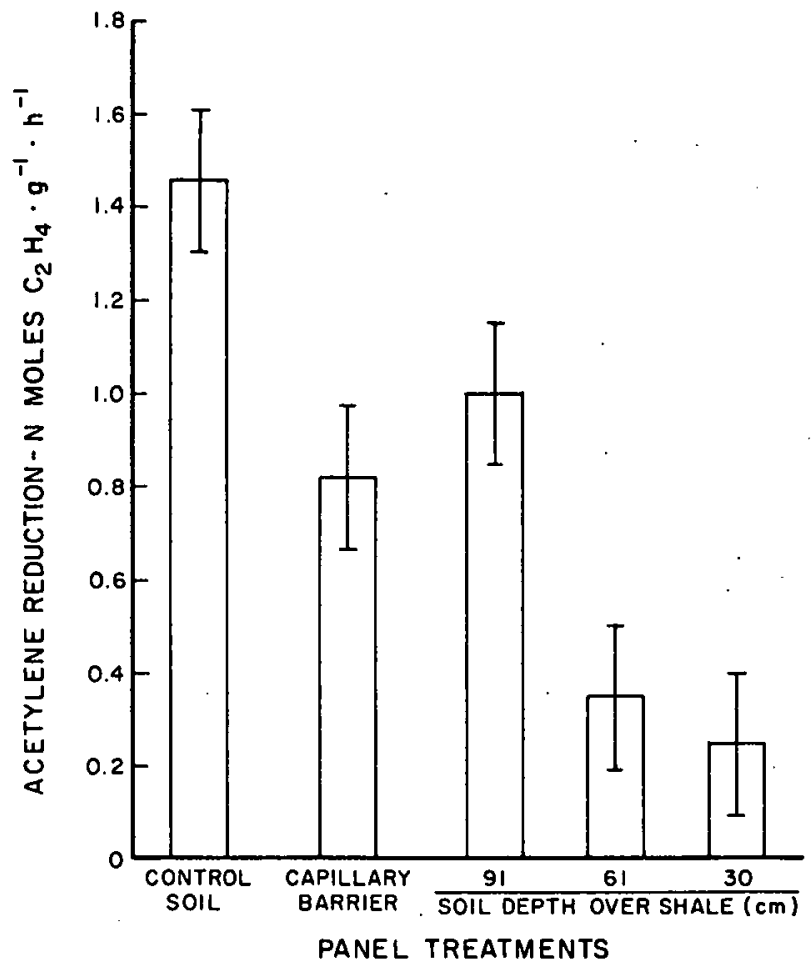

Figure 34. Effects of soil depth and a capillary barrier on the nitrogen fixation potential of revegetated soil located over retorted shale--1980. (The least significant difference range $(p \leq .05)$ is given.)

barrier soil had markedly higher soil water contents while the other treatments had lower and more similar values (Figure 37 ). This same relationship was observed for the soil organic matter, phosphatase, and dehydrogenase ( $g$ lucose less control) data when all soil depths were averaged. The only exception to this general trend was shown by the ATP values. Other than for the $91 \mathrm{~cm}$ depth soil samples (which were significantly higher) the ATP values from the control, capillary, and other treatments were lower (Figure 38 ).

In summary, these results suggest that it should be possible to use selected. soil microbial assays to detect possible effects of retorted shale materials on surface soil. This should be valuable to improving reclamation management with these materials.

\section{Stored Soil Experiment}

The stored soil experiment has been monitored for a three-year period in conjunction with Dr. Reeves of the Botany Department at CSU. During this period it has been possible to increase the intensity of monitoring and to sample the $274-\mathrm{cm}$ (9-foot) depth during 1980. The major conclustons which can be drawn from this work to the present time include the following: 


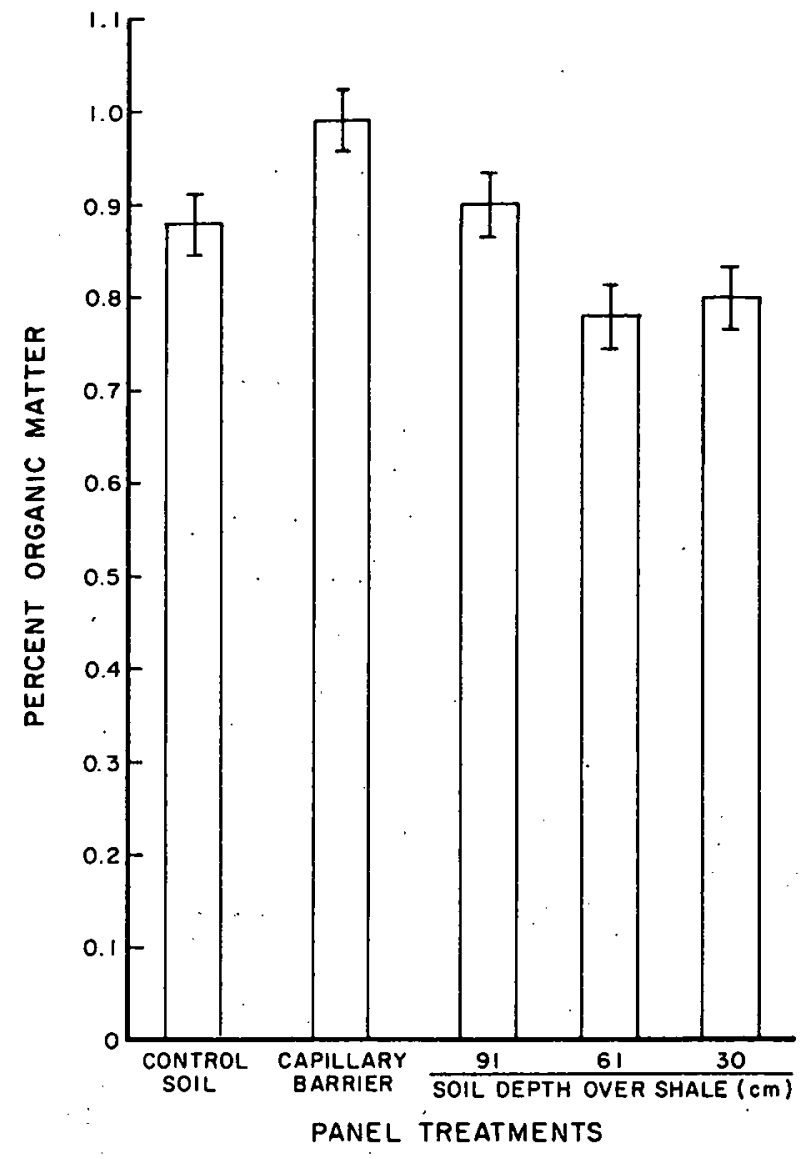

Figure 35. Effects of soil depth and a capillary barrier on the percent organic matter of revegetated soil located over re-. torted shale--1980. (The least significant difference range ( $p \leq .05)$ is given.)

1. The storage pile has a high degree of heterogeneity which made identification of microbiological trends difficult.

2. With the soil volume which has been used, it appears that surface and edge effects are influencing microbial activities, independent of the particular plant--no plant and soil depth variables which were tested in the. experiment.

3. Over three years no major changes in general microbial activities occurred which can be attributed to surface versus subsurface location or with the presence or absence of plants. Mycorrhizal responses which were observed will be discussed in another section of this report.

The soil storage pile was first sampled in May 1978, approximately four months after construction. During this time no plant cover had been: established.

The Pearson coefficient correlations for the. 1978 analysis indicated strong direct relationships between the soil organic matter levels and

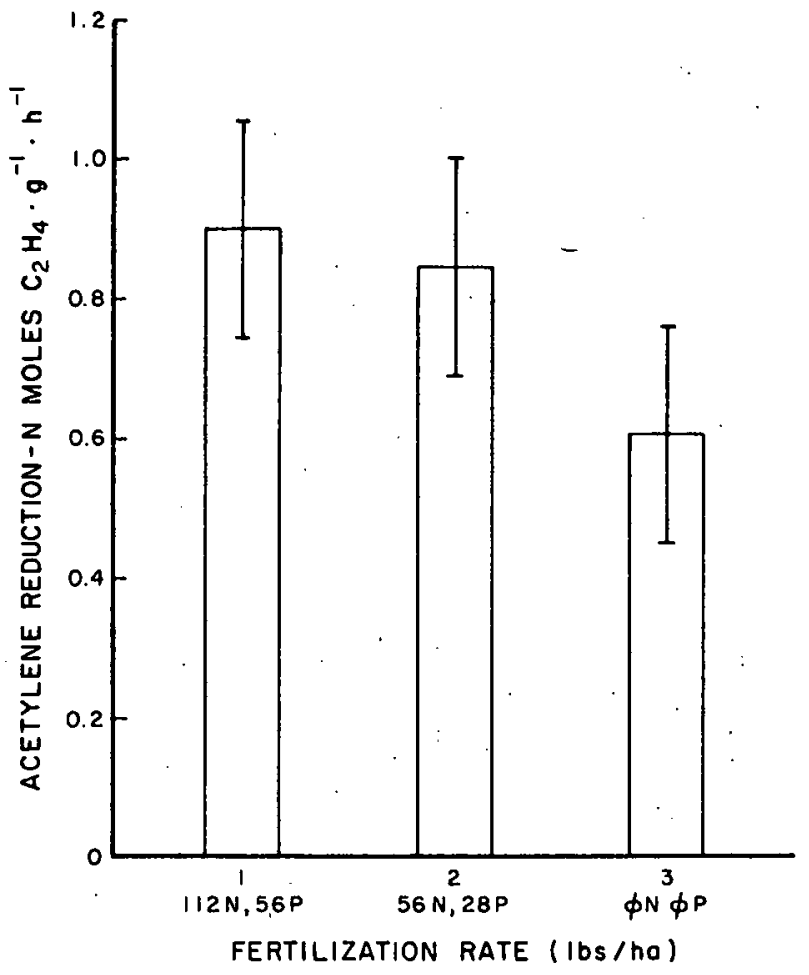

Figure 36. Effects of fertilization rate on the nitrogen fixation potential of all surface soils on the Retorted Shale Successional plot--1980. (The least significant difference range ( $p \leq .05$ ) is given.)

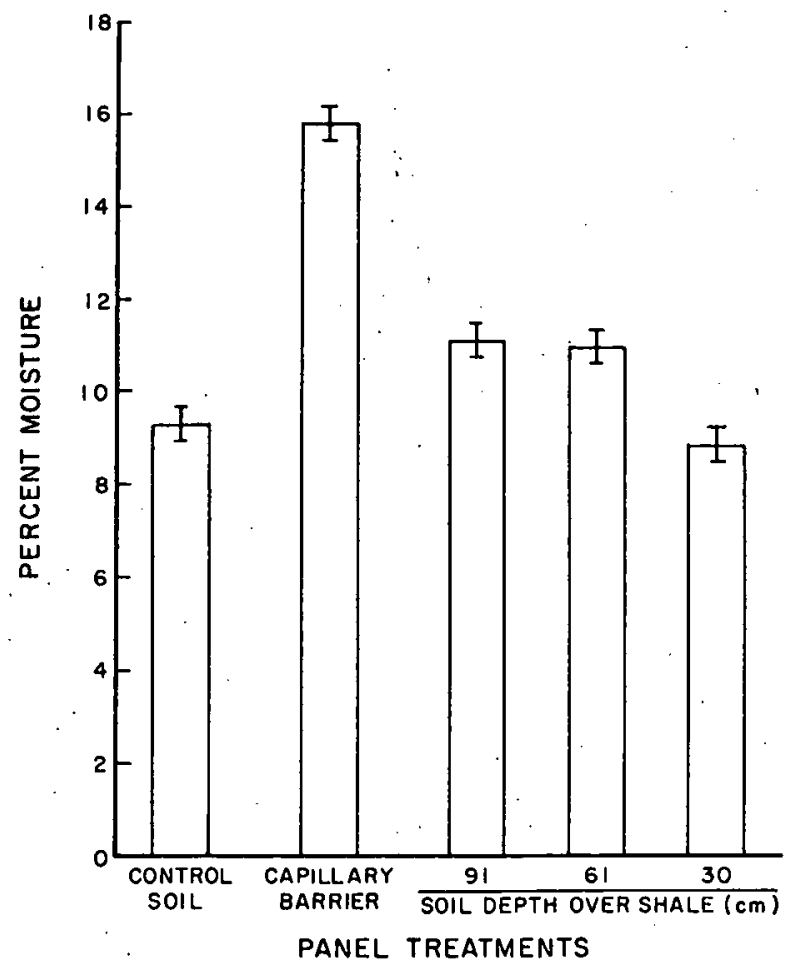

Figure 37. Effects of soil depth and a capillary barrier on the percent moisture of revegetated soil located over retorted shale--1980. (The least significant difference range ( $p \leq .05)$ is given.) 


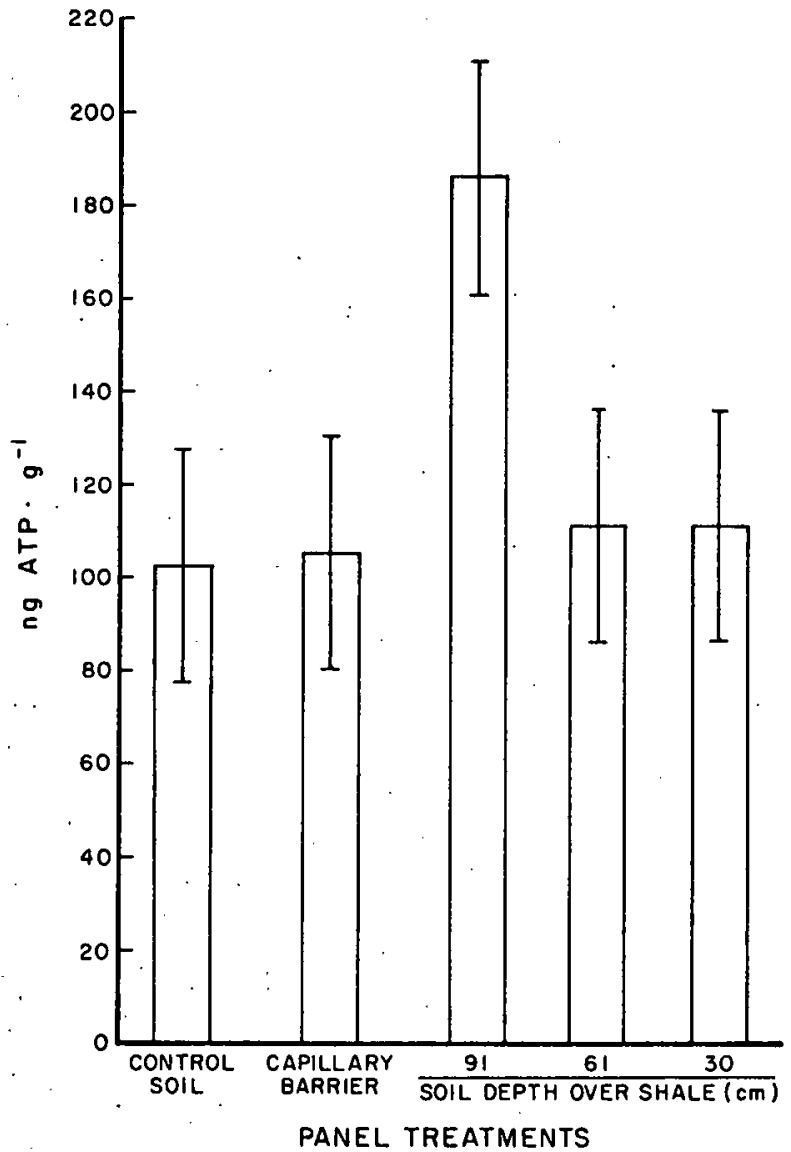

Figure 38. Effects of soil depth and a capillary barrier on the adenosine triphosphate (ATP) level of revegetated soil located over retorted shale--1980. (The least significant difference range $(p \leq .05)$ is given.)

microbiological activities are shown in the 1979 progress report's Table 50 .

Early in the experiment (1978) soil at the surface of the storage pile had significantly lower water contents than those from the deeper locations. In addition, the surface soil had a significantly lower organic matter level, to approximately the $61-\mathrm{cm}$ level. The nitrogen fixation potentia.l assays also showed interesting trends, with the nonplant-associated nitrogen fixation potential of the surface soil layer at a lower level (see 1979 progress report).

By the time of 1979 sampling, which was also only completed to a $182-\mathrm{cm}(6-$ foot $)$ depth, additional changes were evident. For the majority of the parameters, no bore or depth effects had occurred after one and one-half years of storage (see 1980 progress report).

Based on the variability which appeared to be inherent in the soils in the storage stockpile, for the 1980 sampling 10 bores were completed to a 274-cm (9-foot) depth. The data for the genera 1 microbial parameters were analyzed both for cumlative depth and bore effects.

For the comparison based on depth, no significant differences were found for the percent soil organic matter. In contrast, the surface soils had a decreased soil water content (Figure 39) and markedly increased nitrogen fixation potential (Figure 40) and dehydrogenase activity both with (Figure 41) and without (Figure 42) added glucose.

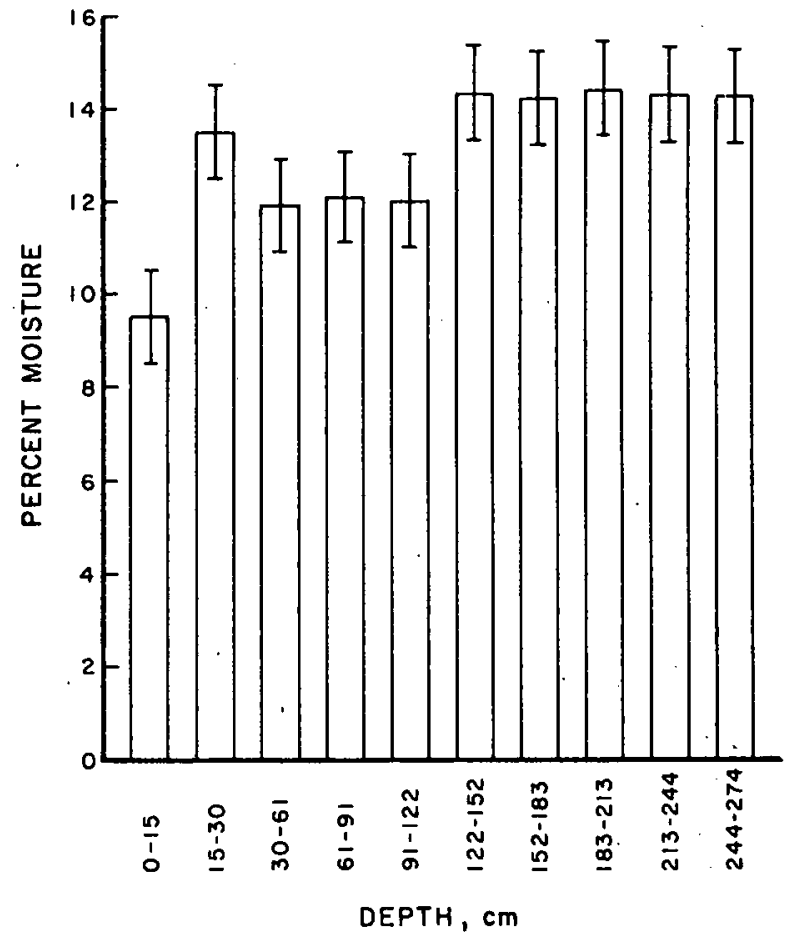

Figure 39. Effects of soil depth on soil moisture in the soil storage pile--1980. (The least significant difference range ( $p \leq .05)$ is given.)

This trend was also shown for the soil ATP, al though there was some variability in the center volume of the stored soil pile (Figure 43). Soil phosphatase and viable actinomycetes and bacteria did not show particular surface effects, although some variations were observed in samples from the center of the stockpile.

For the analyses of bore effects, no significant differences were observed for most parameters, except for the phosphatase and ATP values. For both of these parameters, higher activities were observed at the ends of the pile with the southern end (not revegetated) showing a tendency to higher values for both of these parameters (Figures 44 and 45). These results suggest that there may be geometric effects on the soil moisture responses which may be as important as the presence or absence of vegetation. 


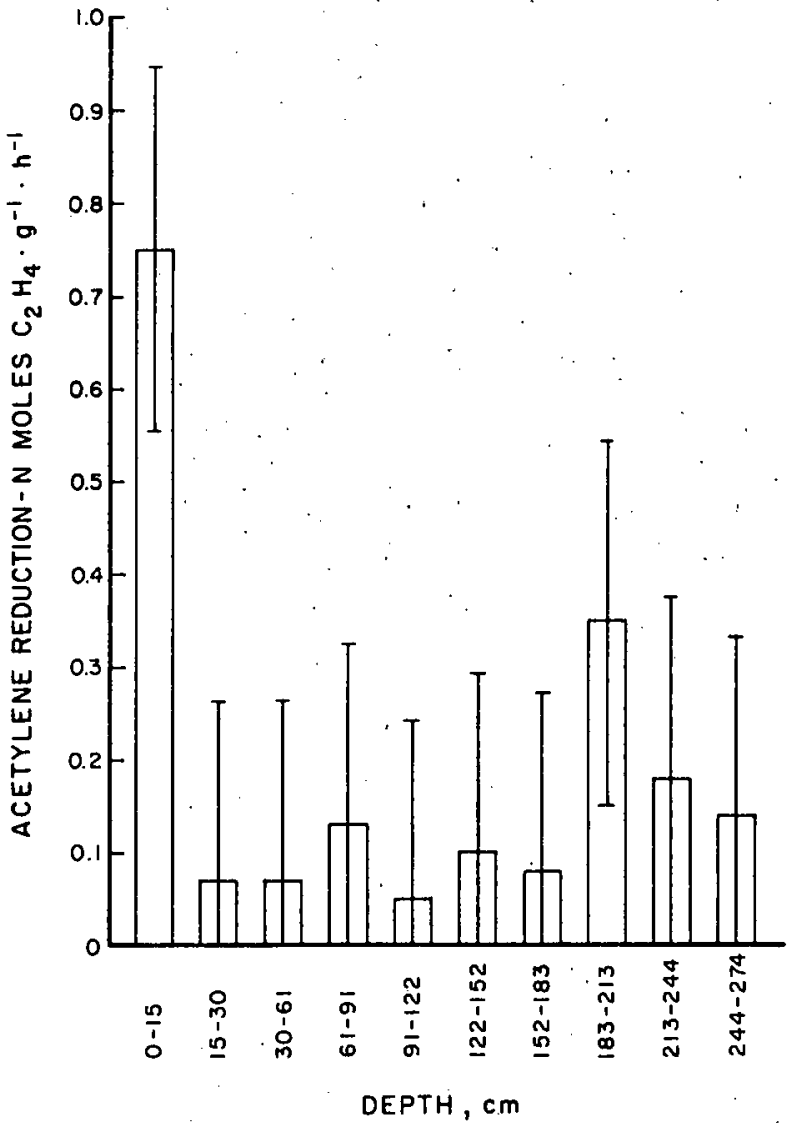

Figure 40. Effects of soil depth on nitrogen fixation potential in the soil storage pile--1980. (The least significant difference range ( $p \leq .05$ ) is given.)

Retorted Shale Effects on Soil Microbiological Processes

This information has been summarized by Hersman and Klein (1979) and is included in the 1979 progress report.

Retorted Shale and Ammonium Ion Effects on Nitrogen Fixation Potential

Studies carried out by Hersman and Klein (1979) have shown that retorted shale will cause distinct decreases in soil nitrogen fixation potential (see 1979 progress report).

\section{Ammonia Volatilization}

The cumulative amounts of ammonia volatilized from the soils treated with ammonium are shown in Figure 46), with values corrected for $\mathrm{NH}_{3}-\mathrm{N}$ trapped in the blank gas train. The soil treated with

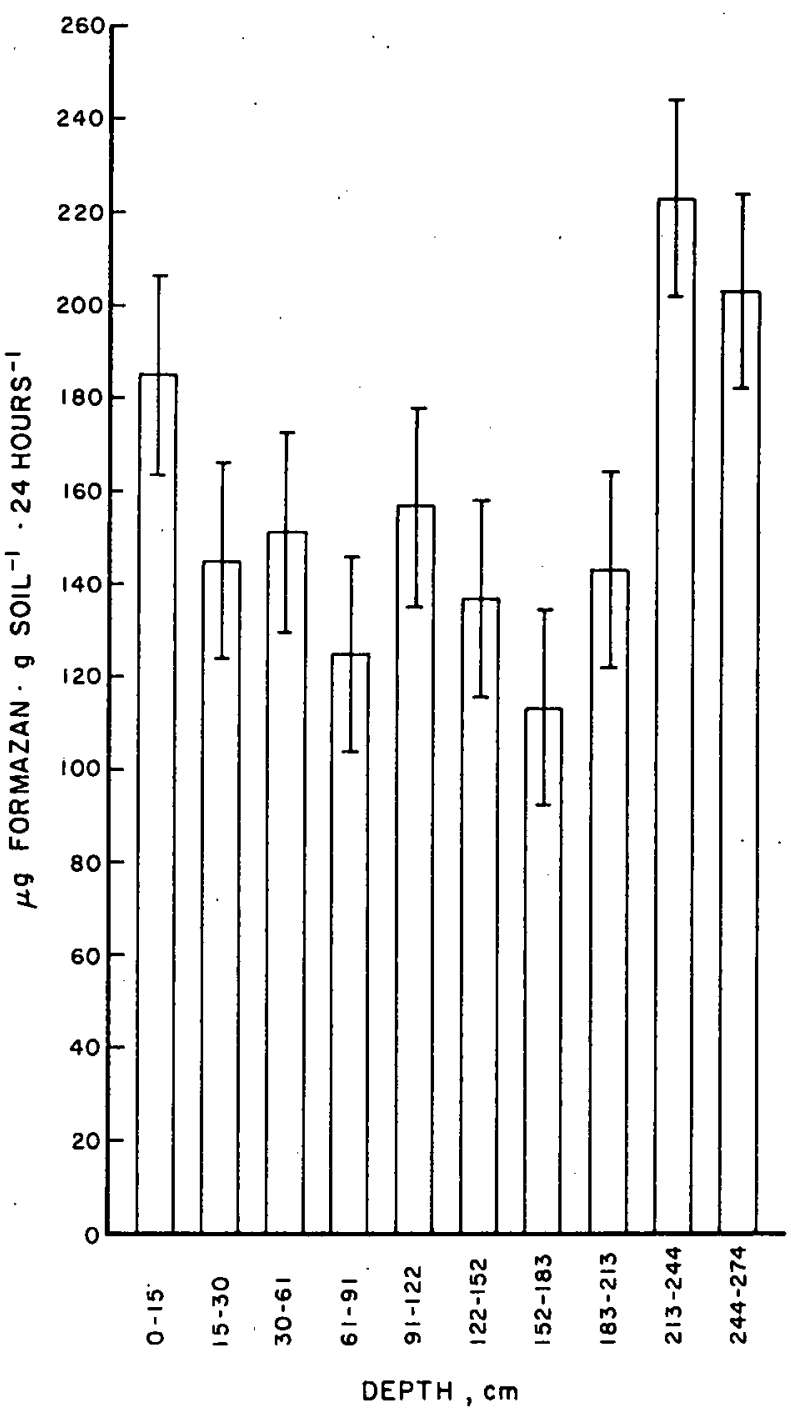

Figure 41. Effects of soil depth on dehydrogenase activity (glucose-amended less controls) in the soil storage pile--1980. (The least significant difference range ( $p \leq .05$ ) is given.)

$100 \mathrm{~g} \mathrm{NH} \mathrm{N}_{4}^{+} \mathrm{N} / 1$ did not show any additional ammonia volatilization after the first week, and less than $3 \%$ of the amount added was released. The soils treated with $375 \mathrm{mg} \mathrm{NH} 4-\mathrm{N} / 1$ showed continued volatilization of $\mathrm{NH}_{3}$ for about 28 days. At that time the soils had lost an average of $6.8 \mu \mathrm{g} \mathrm{N} / \mathrm{g}$ dry weight of soil or about $8 \%$ of the $\mathrm{NH}_{4}^{+}-\mathrm{N}$ originally added.

Nitrate nitrogen levels in all the treated soils at the end of the experiment indicated that virtualiy all (94\%-113\%) of the nitrogen added as $\mathrm{NH}_{4}^{+}$had been oxidized to nitrate. These results indicate that ammonia volatilization is probably important in these soils only when relatively high additions of $\left(\mathrm{NH}_{4}\right)_{2} \mathrm{SO}_{4}$ fertilizer are made. Soils receiving additions of $\mathrm{NH}_{4}^{t}-\mathrm{N}$ approaching $100 \mu \mathrm{g} \mathrm{N} / \mathrm{g}$ may lose approximately $10 \%$ of the added nitrogen if 


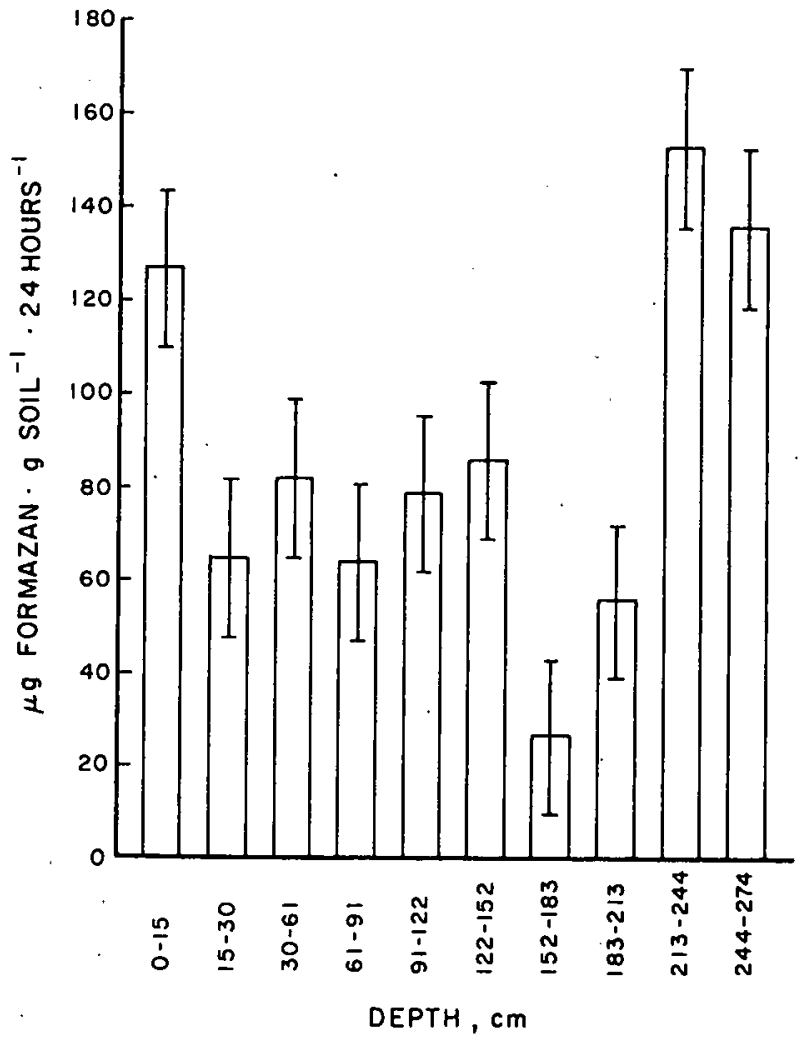

Figure 42. Effects of soil depth on control dehydrogenase activity in the soil storage stockpile--1980. (The least significant difference range $(p \leq .05)$ is given.)

the soil becomes moist and temperatures are moderate. It also appears that nitrification will probably be complete under these conditions.

\section{Plant-Associated Nitrogen Fixation Potential}

\section{Laboratory Studies} report.

These have been summarized in the 1979 progress

\section{Field Studies}

No significant differences in acetylene reduction rate per milligram dry weight of nodule could be detected between any of the species of legume or between any of the various treatments used in this study. It could be shown, however, that the nodulation frequency for all species was higher ( $p \leq .05)$ with no fertilizer in comparison with a $56 \mathrm{~kg} \mathrm{~N} / \mathrm{ha}$ treatment. The average nodulation frequency with $112 \mathrm{~kg} \mathrm{~N} / \mathrm{ha}$ was lower than without fertilizer, but the difference was not statistically significant (Figure 47). Analysis of soil samples taken about the same time as the acetylene reduction work was being done shows an increasing trend in both the

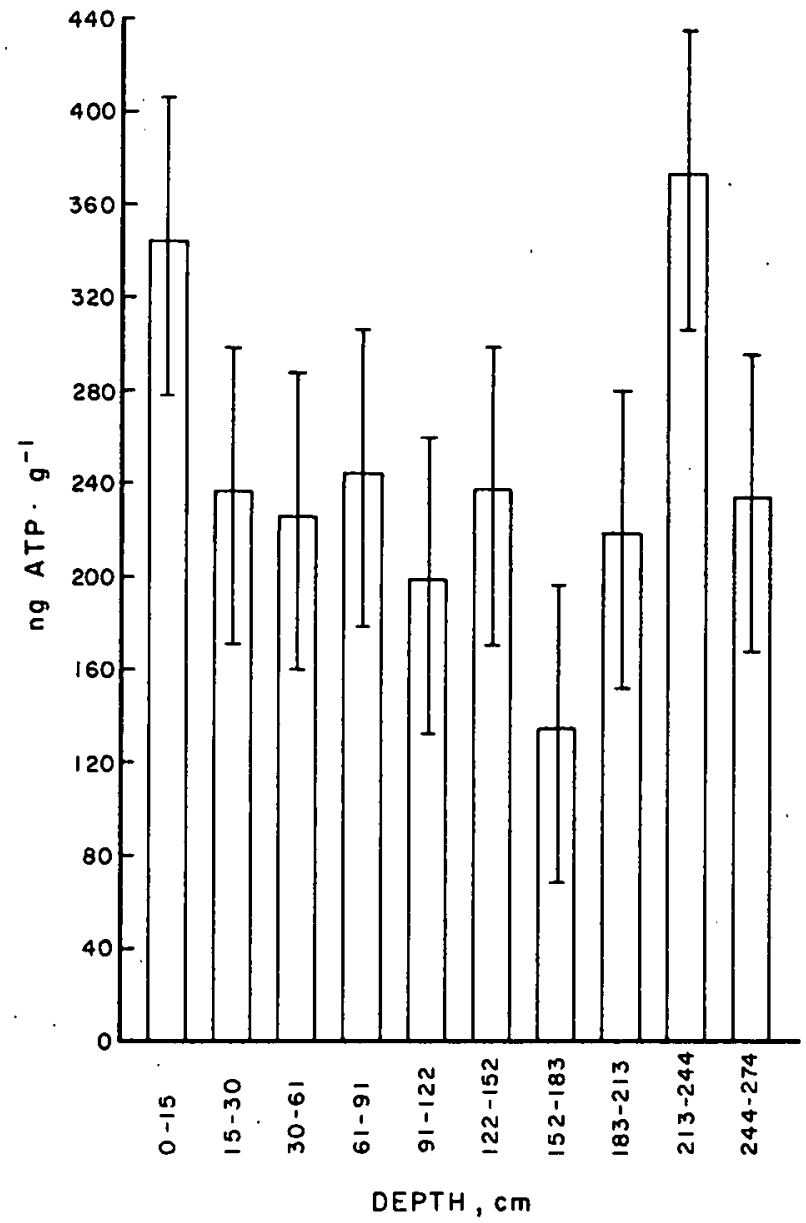

Figure 43. Effects of soil depth on the adenosine triphosphate (ATP) level in the soil storage pile--1980. The least significant difference range ( $p \leq .05)$ is given.)

average $\mathrm{KCl}$ extractable $\mathrm{NH}_{4}^{+}-\mathrm{N}$ and the extractable $\mathrm{NO}_{3}^{-} \mathrm{N}$ with fertilization. However, the concentration of neither nitrogen species was significantly different $(P \leq .05)$ regardless of fertilizer application rate. It appears that acetylene reduction per unit dry weight of nodule tissue is constant and that legumes have a higher nodulation frequency with a lower soil nitrogen status. We may assume, therefore, that the amount of nitrogen fixed by legumes in unfertilized soil is somewhat higher than where fertilizer is applied.

\section{Nitrification and Denitrification}

Using incubation techniques for periods of 40 days, the oxidation of ammonium in soils mixed with varying concentrations of Paraho processed oil shale has been monitored. With shale present at $10 \%$ or more, nitrification was reduced as compared to soil not mixed with spent oil shale. In addition, an appreciable nitrate accumulation occurred in soils mixed with greater than. $10 \%$ spent 


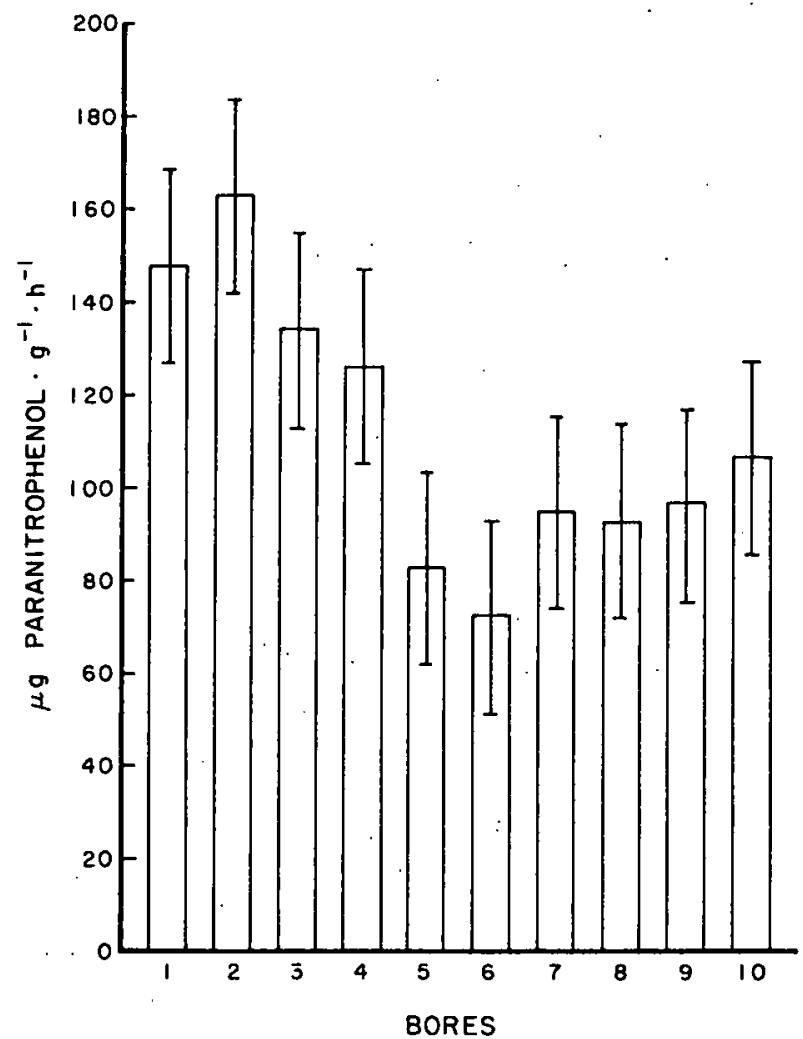

Figure 44. Bore effects on phosphatase activity in the soil storage pile--1980. (The least significant difference range $(p \leq .05)$ is given.)

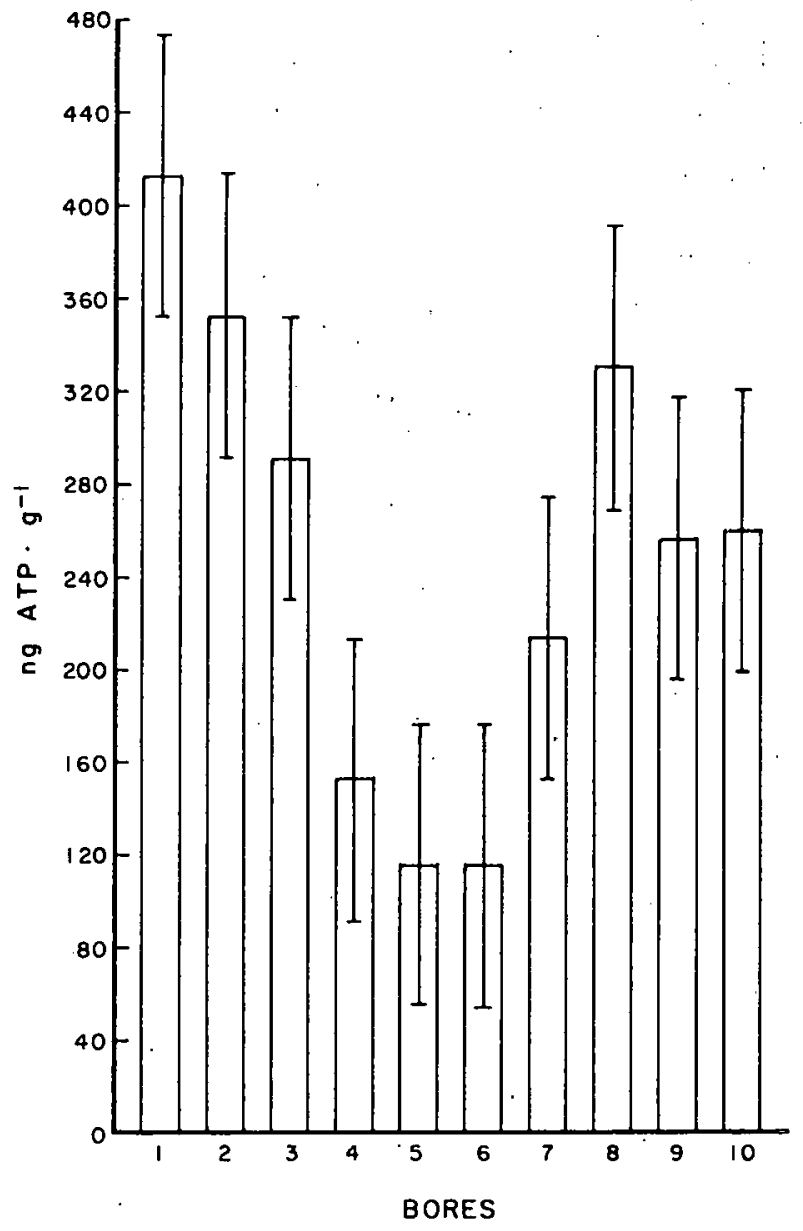

Figure 45. Bore effects on the adenosine triphosphade (ATP) level in the soil storage pile--1980. The least significant difference range ( $p \leq .05$ ) is given.)

shale, which was not seen in soil free from shale. These results are preliminary and need to be repeated before definite conclusions can be drawn.

Initial experiments on the denitrification potential of soil of various depths over processed shale and with varied fertilization and vegetation treatment have been initiated using the acetylene inhibition technique. Preliminary results indicate that denitrification can be measured in watersaturated soil under an air atmosphere. Further work is planned. to estimate the impact of denitrification on the nitrogen cycle of revegetated soils and the influence various revegetated soil and management techniques will have on denitrification rates.

\section{DISCUSSION}

Figure 46. Release of gaseous ammonia from Intensive Study Site soils over a 34-day period, expressed a.s percent of nitrogen added. (Means and standard deviations are given.)
The field and laboratory microbiological studies carried out to date indicate that techniques for retorted shale reclamation will have distinct 


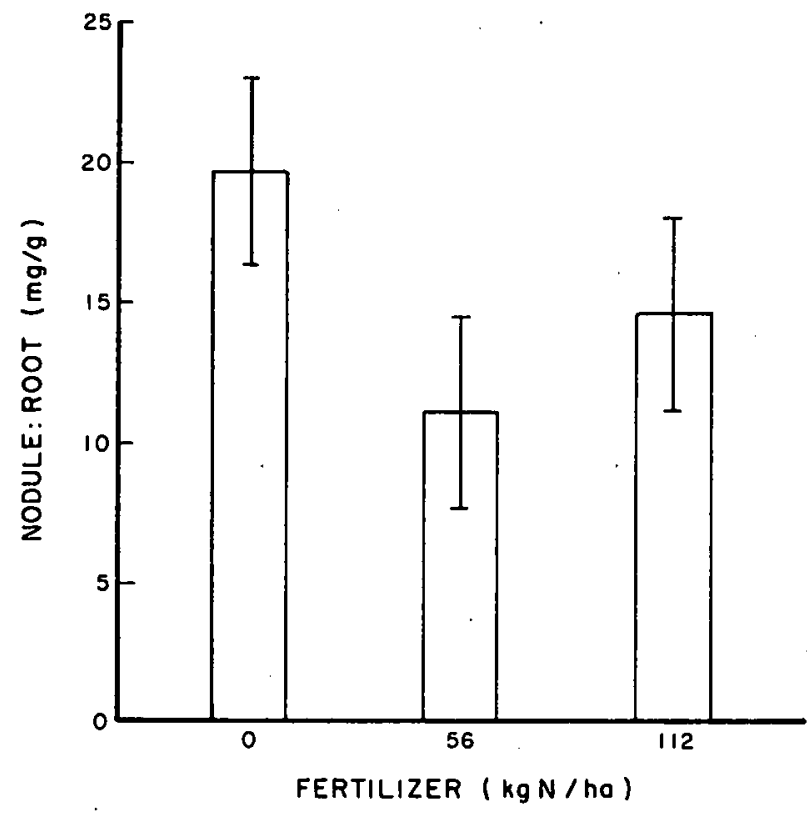

Figure 47. Effects of fertilizer on nodule weight per unit roots for the legume field experiment--1980. (The least significant difference range ( $p \leq .05)$ is given.)

effects upon bel-owground soil microbiological processes and that microbiological monitoring may be useful in the design and management of these programs. Different planting mixtures may be better suited for use under irrigated or nonirrigated conditions, and nitrogen additions do not appear to have major effects on reestablishment or enhancement of microbiological processes. There is some indication that these may lead to a decreased nitrogen fixation potential. Generally, the presence of retorted shale in proximity to surface soil will lead to a decrease in microbiological activities, and distinct effects on nitrogen fixation potential have been observed.

Based on results obtained on the Revegetation Techniques plot at the Intensive Study Site, irrigation during plant community establishment appears to exert a major effect on subsequent plant growth and related microbial activity. The increases in ATP levels, dehydrogenase, phosphatase, nitrogen fixation processes and on the percent organic matter which has been observed support this concept. Water applications also had long-term effects, as irrigation-related changes were noted in the plots which had been irrigated from the previous year. This was believed to largely be a result of increased organic matter in the upper soil profile.

Equally important (from a revegetation and reclamation veiwpoint) were the effects of the other management variables, namely seed mixtures and seeding techniques, which had distinct effects on microbiological parameters.

The percent soil organic matter al so demonstrated strong correlations with $\mathrm{pH}$, phosphatase activity, and $\mathrm{N}_{2}$ fixation potential for both sampling periods. Although each parameter measures a different aspect of the microbiological compartment, these strong correlations indicated that these have similar responses to the imposed management variables.

These results suggest that added water will allow introduced species to respond more quickly, causing changes in decomposer processes. Whether this leads to a more stable, lower energy input plant community on a long-term basis remains to be determined.

The surface disturbed successional plot results indicate that seed mixtures will have a major effect on the accumulation of organic matter in the soils, with the introduced grass mixtures and the native grass-forb-shrub mixture being related to the highest soil organic matter levels (both with and without mulching).

Based on laboratory studies, retorted shale is capable of causing distinct decreases in several important microbial functions. ATP levels, nitrogen fixation, ${ }^{14} \mathrm{C}-\mathrm{gl}$ ucose mineralization, fungal viable populations, and dehydrogenase activity decreases have occurred in the presence of shale. However, soil moisture, soil pH, bacterial and actinomycete viable counts, and especially respiration rates all remained relatively unchanged. The reduction in nitrogen fixation rates suggests that asymbiotic nonphotosynthetic nitrogen fixing bacteria could be especially sensitive to the presence of retorted shale. Loss of these microbial functions, especially in a soil already of low biological activity, could influence plant reestablishment.

Retorted shale has been strongly associated with a reduction of microbial functions both in the laboratory and in field studies. Consequently, one might naturally wonder what characteristic(s) of retorted shale are causing these effects upon the soil microbial community. At the present time, information is not available on this point. However, research directed towards identifying particular factors which might control this interaction is planned in the next year. This will be especially critical in the design and evaluation of capillary barriers and other separation systems.

The stored soil experiment generally has not yielded the type of or quality of information which had been desired when the experiment was initiated. This may be due to the heterogeneity of the surface soil material used in construction of the pile.

These variations include $\mathrm{pH}$ and the "edge effects" which appear to have influenced several of the microbiological parameters which were used in this study. The design and conduct of stored soil microbiological experiments should be re-assessed based on these results.

\section{LITERATURE CITED}

American Public Health Association Inc. 1975. Standard methods for the examination of water and waste-water, 14th ed. American Public Health Association Inc., Washington, D.C. 
Belser, L. W., and E. L. Mays. 1980. Specific inhibition of nitrite oxidation by chlorate and its use in assessing nitrification in soils and sediments. Appl. Environ. Microbiol.39(3): 505-510.

Hersman, L. E., and D. A. Klein. 1979. Retorted oil shale effects on soil microbiological characteristics. J. Environ. Qua 1. 8:520-524.

Nakas, J. P., and D. A. Klein. 1980. Mineralization capacity of bacteria and fungi from the rhizosphere-rhizoplane of semi-arid grassland. App1. Environ. Microbiol. 39(3):113-117.

Peters, D. B. 1965. Water availability. Pages 279-285 in C. A. Black, ed. Methods of soil analysis. American Society of Agronomy, Inc., Madison, Wis.

Sherewood, J. E. 1979. The rhizosphere effect on antibiotic-resistant Arthrobacter and Pseudomonas. M.S. Thesis. Colo. State Univ., Ft. Collins. $90 \mathrm{p}$.

Sorensen, D. L., D. A. Klein, W. J. Ruzzo, and L. E. Hersman. 1981. Microbial activities in revegetated surface soil overlying spent Paraho process oil shale. J. Environ. Qual. In press.

Strickland, J. D. H., and T. R. Parsons. 1968. Pages 77-80 in A practical handbook of seawater analysis. Fish Res. Board Can. Bull., vol. 167.

\section{AVAILABLE PUBLICATIONS AND/OR ABSTRACTS}

Hersman, L. E., and D. A. Klein. 1979. Evaluation of retorted soil shale effects on the microbiological characteristics of surface soil used in land reclamation and revegetation processes. J. Environ. Qual. 8:529-524.

Klein, D. A., L. E. Mersman, and D. L. Sorensen. 1979. Revegetation effects on surface soil microbiological characteristics. Pages 229223 in Stanley B. Carpenter, ed. Proceedings, Symposium on Surface Mining Hydrology, Sedimentology, and Reclamation. Univ. Kentucky, Lexington, 4-7 December.

Klein, D. A., L. E. Hersman, and S-Y. Wu. 1980. Monitoring of retorted oil shale effects on surface soil nitrogen fixation processes: A resource for design and management of land reclamation systems. Pages 546-554 in Charles Gale, ed. 0il Shale Symposium: Sampling, analysis, and quality assurance. U.S. Environmental Protection Agency.

Klein, D. A., L. E. Hersman, and F. B. Reeves. 1979. Storage effects on the microbiological characteristics of surface soils used in oil shale revegetation programs. Society for Range Management Annual Meeting, Casper, Wyo. (Abstr.)

Hersman; L. E., and E. Molitoris. 1979. Effects of retorted oil shale on nonplant-associated. and leguminous nitrogen fixation. American Society of Microbiology Annual Meeting, Los Angeles, Calif. (Abstr.)

Klein, D. A., and L. E. Hersman. 1979. Revegetation technique effects on the microbiological characteristics of surface soil used for reclamation over retorted oil shale. American Society of Microbiology Annual Meeting, Los Angeles, Calif. (Abstr:)

Klein, D. A., D. L. Sorensen, L. E. Hersman, and E. F. Redente. 1980. Revegetation managementsoil microbiological interactions: Results from field trials in the Piceance Basin, Colorado. In Coralee Brierley, ed. Mineral waste stabilization. New Mexico Bureau of Mines and Mineral Resources Press, Socorro. In press.

Klein, D. A., D. L. Sorensen, E. F. Redente, and J. P. Nakas. 1980. Decomposer parameter correlations in longer-term field experiments in natural and revegetated rangelands. Second International Symposium on Microbial Ecology. Univ. Warwick. (Abstr.)

Klein, D. A., D. L. Sorensen, and E. F. Redente. 1980. Revegetation management-soil microbiological interactions. American Society of Microbiology. Annual Meeting. Dallas, Tex. (Abstr.)

Sorensen, D. L., D. A. Klein, W. J. Ruzzo, and L. E. Hersman. 1981. Microbial activities in revegetated surface soil overlying spent Paraho process oil shale. J. Environ. Qual. In press. 


\title{
IMPORTANCE OF MYCORRHIZAL FUNGI IN REVEGETATING DISTURBED SOILS AND RETORTED SHALE
}

\author{
F. Brent Reeves, Jr., Janine Sabaloni, and Steve Schmidt \\ Department of Botany and Plant Pathology \\ Colorado State University \\ Fort Colzins, Colorado 80523
}

\section{OBJECTIVES}

Most important plants in rangelands of western Colorado have symbiotic fungi growing within their roots; the fungus-root is called a mycorrhiza. The extensions of the fungus from the root into the soil greatly increase the effective surface area of the root. Thus, the mycorrhiza (when compared to a root) is more effective in absorbing nutrients.

Both disturbed and stored soil may lack vegetation for long periods of time. Because the mycorrhizal fungi are obligately dependent on the ir hosts for nutrition, the absence of vegetation can lead to substantial reductions in the population of mycorrhizal fungi. El imination or death of these fungi means that mycorrhiza-dependent plants will not survive under natural conditions.

To maximize reclamation procedures, knowledge of the population ecology of these fungi is beneficial in understanding the establishment and succession of plants that depend on these fungi. The primary goals of this subproject are to determine the changes in populations of mycorrhizal fungi in disturbed or stored soils and how these changes affect the relative success of establishment and subsequent succession of the aboveground vegetation. The specific objectives for the past year were as follows:

1. Monitor the Retorted Shale Successional P.lot for changes in the mycorrhizal inocuTum potential (MIP) of the soil as a function of depth and fertilizer treatment.

2. Monitor the Topsoil Storage Pile for changes in the MIP as a function of depth and time.

3. Monitor the disturbance plots and correlate changes in MIP with succession of native plants.

4. Monitor the Long-Term Fertility plots for effects of added nitrogen fertilizer on MIP of the soil.

5. Compare the effects of different strains of mycorrhizal fungi on growth and survival of native plants.
6. Determine seasonal variations in populations of mycorrhizal fungi.

PROGRESS TO DATE

Retorted Shale Successional Plot

This study was initiated in 1977 to test the effect of surface disposal plans for processed shale on plant.growth and succession and on microbiological processes in the soil. Six panels (plots) representing artificial profiles of soil over shale were constructed. These panels (Figure 48) were:

1. Retorted shale to surface

2. $30 \mathrm{~cm}$ soil over shale

3. $91 \mathrm{~cm}$ soil over shale

4. Check panel (no shale, only soil)

5. $61 \mathrm{~cm}$ soil over shale

6. $61 \mathrm{~cm}$ soil over rock capillary barrier over shale

For mycorrhizal analysis subplots B1, B2, and B3 on each of the panels were sampled. These subplots were planted with a native grass-forb-shrub species mixture (Mixture $B$ ) and fertilized at $112 \mathrm{~kg} \mathrm{~N} / \mathrm{ha}, 56 \mathrm{~kg} \mathrm{P} / \mathrm{ha}(\mathrm{BI})$; or $56 \mathrm{~kg} \mathrm{~N} / \mathrm{ha}, 28 \mathrm{~kg}$ $\mathrm{P} / \mathrm{ha}$ (B2); or $0 \mathrm{~kg} \mathrm{~N} / \mathrm{ha}, 0 \mathrm{~kg} \mathrm{P} / \mathrm{ha}$ (B3). Each panel had three replicates for each subplot. Details of these panels are found in Redente et al. of this report.

On June 11, 1980, the B1, B2, and B3 subplots were sampled using a $7.5 \mathrm{~cm}$ soil corer. Soil was sampled to the shale-soil interface, and each core was divided into $15-\mathrm{cm}$ samples. Each sample was sieved through a $1-\mathrm{cm}$ sieve and analyzed for MIP using the a slight modification of our bioassay (Moorman and Reeves 1979). Rather than using 9-cm square pots, tubular "Conetainers" (used in forest nursery practices) $3.5 \times 21 \mathrm{~cm}$ were planted with pregerminated DeKalb XL 321 corn. The bioassay was run 


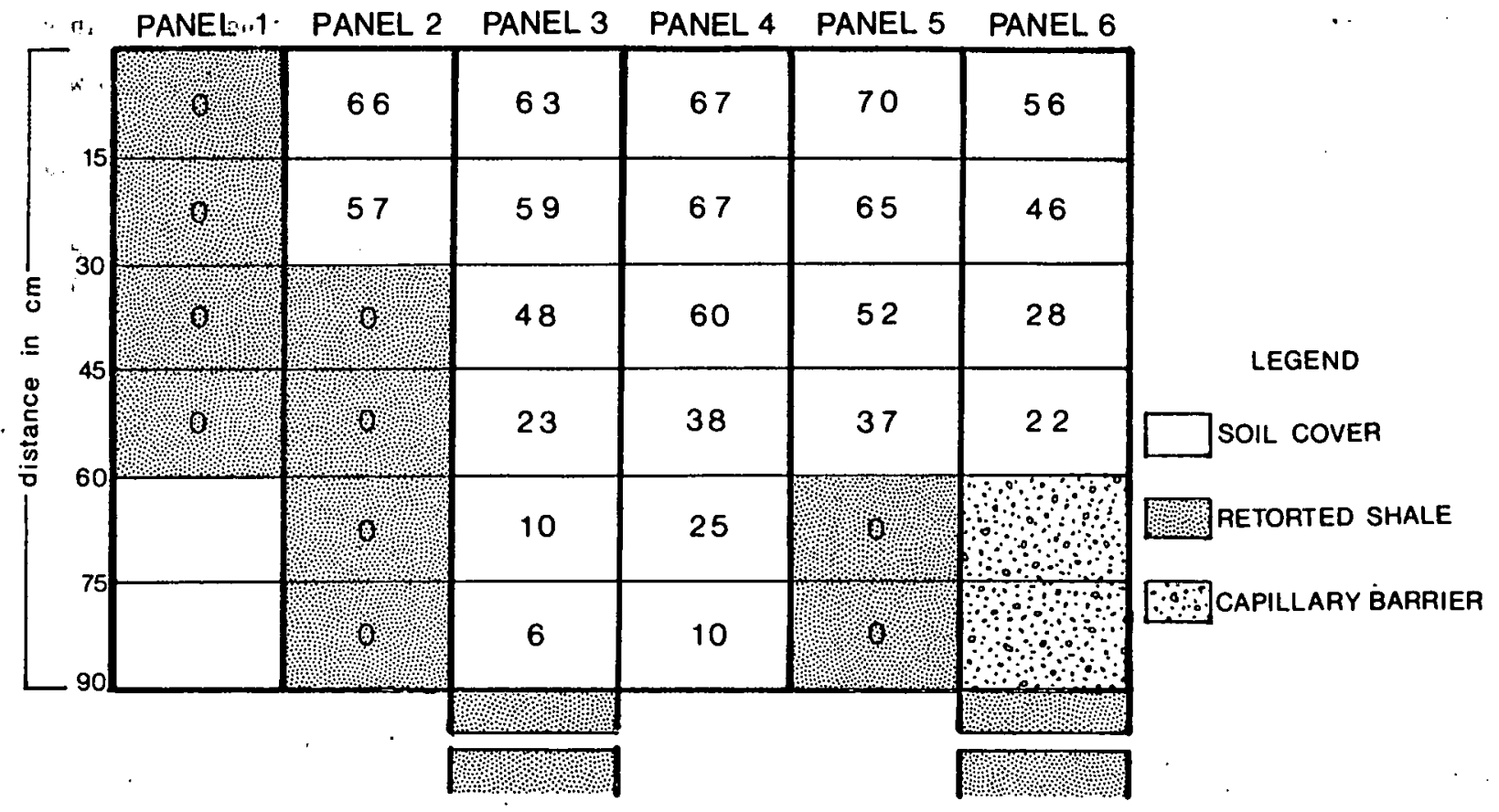

Figure 48. Mycorrhizal inoculum potential (MIP) of shale and soil cover over shale in the Retorted Shale Successional P1ots, Panel 1-6. MIP mean values are based on Subplots B1, B2, and B3.

for 21 days in a growth chamber $(\mathrm{d} / \mathrm{n} 14 / 10 \mathrm{hr}$; temp $28 / 21^{\circ} \mathrm{C}$; light approx. $350 \mu \mathrm{E} / \mathrm{m}^{2} / \mathrm{sec}$ ).

\section{Results and Discussion}

The specific objective of this subproject was to determine if there are detrimental effects on the MIP of the soil-covering processed shale due to the processed shale. Sampling discrete depths of the soil over shale allowed for detection of subtle changes of the MIP at comparable levels. Previous research on Panel 1 (shale-to-surface) indicated a 0 MIP for all treatments (B1, B2, and B3).

: Analysis of the 1980 data from the subplots using a three-way ANOVA for Panels 2-6 (Figure 48, different depths of soil over shale), fertilizer treatment (112 kg N/ha, $56 \mathrm{~kg} \mathrm{P} / \mathrm{ha}$ vs. $56 \mathrm{~kg} \mathrm{~N} / \mathrm{ha}$, $28 \mathrm{~kg} \mathrm{P} / \mathrm{ha}$ vs:" $0 \mathrm{~kg} \mathrm{~N} / \mathrm{ha}, 0 \mathrm{~kg} \mathrm{P} / \mathrm{ha}$ ), and depth $(15,30,45,60,75$, and $90 \mathrm{~cm}$ soil over shale) indicates that there are no significant differences in the MIP of the soil due to fertilizer treatment $(p<.05)$. This data supports the previous results reported in 1978 and 1.979 for the lack of fertilizer effects on MIP on these panels and is consistent with the lack of fertilizer effects on MIP reported for the Long-Term Fertility Plots in this report." :

3 Based on data for three years we conclude that up to $112 \mathrm{~kg} \mathrm{~N} / \mathrm{ha}$ and $56 \mathrm{~kg} \cdot \mathrm{P} / \mathrm{ha}$ did not significantly alter the MIP of the soil as measured by our bioassay; thus, the fertilizer treatments up to this level are neither detrimental nor advantageous to the mycorrhizal fungi in these panels. Studies currently are in progress to determine if there are significant effects on the MIP of semiarid soils when large additions of fertilizers are added to the soil. The data for effects of additions of large amounts of fertilizer will be based on the Long-Term Fertility Plots at the Intensive Study Site.

The three-way ANOVA anaiyses did indicate significant differences $(p<.01)$ in the MIP due to depth effects. Schwab and Reeves (1981) have reported that MIP is significantly reduced below $30-\mathrm{cm}$ depth and approaches zero at less than $1-\mathrm{m}$ depth in undisturbed soils. Results obtained in this 0il Shale Panel Study indicate that there is a steady decline in the MIP from the upper $15 \mathrm{~cm}$ to the deepest depth $(90 \mathrm{~cm})$ sampled (Figure 48 ).

These results indicate that the construction of the soil over shale in these panels was consistent with the decline of MIP found in natural, undisturbed soils; thus; these panels represent an approach to natural conditions found prior to disturbance.

The three-way ANOVA analyses support the previous findings that there are no significant differences between Panels 2-6 in the upper $15 \mathrm{~cm}$ or comparably greater depths of soil across the panels. Thus, the experimental design and sampling methods are consistent with the expected results (i.e., no differences within comparable depths between or among panels).

To determine the effects of retorted shale on MIP, MIP values of soil $15 \mathrm{~cm}$ above the processed shale or capillary barrier were compared using a two-way ANOVA and LSD test for significance, with the check panel (Panel 4) at comparable depths (Table 15). No significant differences were found between Panel 4 (check panel, control) and the other panels--except Panel 6 (barrier over shale). 
In this latter case, the soil at the soil barrier interface was near saturation due to the presence of the capillary barrier. Previous reports (Gerdemann 1968, Keeley 1980) suggest that waterlogged soil may not support mycorrhizae. It is more consistent to ascribe the reduced MIP in Panel 6 to the saturated condition of the soil than to a direct effect from shale, especially since the capillary barrier is supposed to "protect" the soil from the shale leachates.

Table 15. Retorted shale panels showing MIP values for soil $15 \mathrm{~cm}$ above retorted shale or barrier.

\begin{tabular}{ccc}
\hline \multirow{2}{*}{$\begin{array}{c}\text { Soi1 Depth } \\
(\mathrm{cm})\end{array}$} & \multicolumn{2}{c}{ MIP Valuest } \\
\cline { 2 - 3 } & No Shale & $\begin{array}{c}15 \mathrm{~cm} \text { Soil } \\
\text { Over Shale }\end{array}$ \\
\hline $15-30$ & $67^{\mathrm{a}}$ & $57^{\mathrm{a}}$ \\
$45-60$ & $38^{\mathrm{b}}$ & $37^{\mathrm{b}}, 22^{\mathrm{c}}$ \\
$75-90$ & $10^{\mathrm{d}}$ & $6^{\mathrm{d}}$ \\
\hline
\end{tabular}

tValues in each row or column with the same letter are not significantly different $(p=.05)$.

\section{Conclusions and Recommendations}

We have only sampled these plots at different depths once, but after three years' growth on soil over shale we can find no significant alterations of MIP of soil in any soil-over-shale panels which are directly attributable to shale effects or fertilizer treatments. MIP decreases with depth of sampling within a panel but is not significantly affected within depth across panels. MIP of processed shale to surface (Pane1 1) remains zero. Previous research suggests that roots may not penetrate shale in a normal manner when covered by soil. Thus, we cannot conclude that the shale sublayer will develop into an effective plant growth medium with time.

\section{Recommendations are:}

1. Use fertilizer treatments up to $112 \mathrm{~kg} \mathrm{~N} / \mathrm{ha}$, $56 \mathrm{~kg} \mathrm{P} / \mathrm{ha}$ if these fertilizer treatments are beneficial to the establishment of the aboveground community.

2. Continue to sample these plots to determine if the shale beneath the soil will support mycorrhizal development and if there are significant changes in MIP over time that can be attributed to direct effects of processed shale.

\section{Stored Soil Experiment}

This study was initiated in 1978 in order to monitor the changes in microbial processes associated with simulated topsoil storage conditions. The stockpile was constructed from the upper
30-50 cm of topsoil material found on the Intensive Study site. The dimensions of the pile are $3 \mathrm{~m}$ high, $5 \mathrm{~m}$ wide at the top, and $23.5 \mathrm{~m}$ long with sides and ends at the angle of repose.

During July 1978 and June 1979 the pile was sampled with a $7.5-\mathrm{cm}$ soil corer to a depth of $150 \mathrm{~cm}$, and in July 1980 the pile was sampled to a depth of $270 \mathrm{~cm}$. Four sample bores were made in 1978 and 1979; ten sample bores were made in 1980 . For each bore, the upper $30 \mathrm{~cm}$ was divided into two subsamples, viz., the upper $15 \mathrm{~cm}$ and the next $15-30 \mathrm{~cm}$. Further samples of the core were made at $30-60 \mathrm{~cm}, 60-90 \mathrm{~cm}, 90-120 \mathrm{~cm}$, and $120-150 \mathrm{~cm}$ in 1978, 1979, and 1980. In 1980 additional samples were made at $150-180 \mathrm{~cm}, 180-210 \mathrm{~cm}, 210-240 \mathrm{~cm}$, and $240-270 \mathrm{~cm}$. Soil for each subsample was sieved through a $1-\mathrm{cm}$ sieve and analyzed according to the bioassay developed by Moorman and Reeves (1979). All bioassays were done in a growth chamber $(\mathrm{d} / \mathrm{n}$ $14 / 10$, temp $28 / 21^{\circ} \mathrm{C}$, 1 ight approx. $350 \mu \mathrm{E} / \mathrm{m}^{2} / \mathrm{sec}$ ) using pregerminated DeKalb XL 321 corn; bioassays were run for 21 days.

In 1979 one-half of the top of the storage pile was planted with a mixture of native grasses, forbs, and shrubs; the other half of the pile was not planted but was manually weeded. Comparable data for 1978, 1979, and 1980 were obtained on $7 y$ from the nonplanted half of the pile. The results of the effects of seeding half the pile were obtained by comparing data from the two separate halves of the pile in 1980.

\section{Results and Discussion}

The specific objective of this subproject was to determine if, during long-term storage, there are detrimental effects on the MIP of the topsoil. The purpose of sampling different depths was to determine if greater depths offered greater or lesser protection of the MIP of the topsoil.

For the unplanted half of the Topsoil Storage Pile, a one-way ANOVA was calculated for depth effects on MIP for each year and a two-way ANOVA for time and depth vs. MIP was calculated for the 1978,1979 , and 1980 data. No significant differences $(p<.05)$ were found for depth effects during any year or during any sampling period within years.

When the 1980 MIP values (Table 16) of the upper $90 \mathrm{~cm}$ of soil (effective root zone) on the planted half of the pile were compared to the MIP values of the unplanted half of the pile, a highly significant difference was found $(p<.01)$. These results indicate that seeding the stored topsoil after two years of storage significantly increased the MIP of the soil even though the MIP had decreased from the original levels present when storage began. Data for depths greater than $150 \mathrm{~cm}$ were limited to a single year. Thus, analyses of changes over time are not possible at this time.

Comparable mean MIP values for the different years of sampling of the unplanted topsoil are given in Table 17 (data for 1980 taken only from the unplanted half of the pile). Selected data for depths $15-30 \mathrm{~cm}, 60-90 \mathrm{~cm}$, and $120-150 \mathrm{~cm}$ for 1978 , 1979 , and 1980 clearly show the consistent downward trend in the MIP over time (Figure 49). 
Table 16. Mean MIP values of the upper $90 \mathrm{~cm}$ (root zone) of soil from the planted vs. unplanted halves of the Topsoil Storage Pile (1980 data).

\begin{tabular}{ccc}
\hline Depth $(\mathrm{cm})$ & Unplanted & Planted \\
\hline $0-15$ & 6.4 & 25.2 \\
$15-30$ & 6.6 & 11.2 \\
$30-60$ & 8.7 & 16.4 \\
$60-90$ & 6.4 & 12.0 \\
\hline
\end{tabular}

Table 17. Mean MIP values for different depths of unplanted, stored topsoil.

\begin{tabular}{rrrr}
\hline $\begin{array}{c}\text { Depth } \\
(\mathrm{cm})\end{array}$ & $\begin{array}{c}\text { July } \\
1978\end{array}$ & $\begin{array}{l}\text { June } \\
1979\end{array}$ & $\begin{array}{l}\text { July } \\
1980\end{array}$ \\
\hline $0-15$ & 18.8 & 11.8 & 6.4 \\
$15-30$ & 25.0 & 15.8 & 6.6 \\
$30-60$ & 21.5 & 14.3 & 8.7 \\
$60-90$ & 18.8 & 14.0 & 6.4 \\
$90-120$ & 17.5 & 15.5 & 6.5 \\
$120-150$ & 25.0 & 24.3 & 5.2 \\
\hline
\end{tabular}

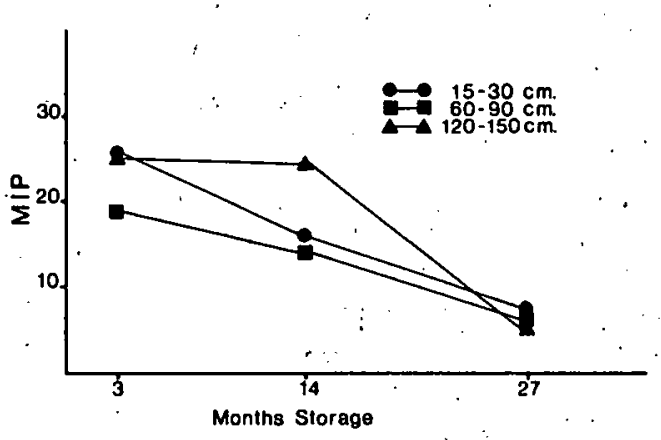

Figure 49. Relationship between decrease in MIP and time of storage of topsoil at depths $15-30 \mathrm{~cm}, 60-90 \mathrm{~cm}$, and $120-150 \mathrm{~cm}$.

A one-way ANOVA of MIP by year (1978, 1979, 1980 ) indicates a highly significant relationship $(p<.01)$. Regression statistics of this data give a correlation coefficient of 0.68 . Thus, we conclude that there are significant decreases in the MIP of topsoil when stored for 27 months under semiarid conditions.

\section{Conclusions and Recommendations}

Clearly, significant decreases in MIP of topsoil occur during storage in excess of 27 months (1980 data). The MIP levels of the unplanted soil are quite low, comparable to those found in severely disturbed semiarid soils of the Piceance Basin. However, by planting selected species on the Topsoil Storage Pile it is possible to significantly raise the MIP values of the upper levels of the stored soil. It is suggested that the MIP values for the upper levels of planted topsoil will continue to increase and approach those found in undisturbed topsoil after several years.

Recommendations are:

1. To preserve MIP on stored topsoil, plant the topsoil with selected mycorrhizal species as soon as possible.

2. Avoid prolonged storage of topsoil. In a relatively short time ( 27 months) significant decreases in MIP occur; these decreases may approach the MIP values found in severely disturbed soils.

3. Continue to monitor this storage pile for changes with time, depth, and planting. If the unplanted or very deep soil approaches a zero MIP, the soil may become less suitable as a growth medium for establishing a. viable community.

\section{Annual Disturbance Plots}

This study was initiated in 1976 to test the effects of soil disturbance on natural succession and on microbial processes. At a mid elevation big sagebrush community in the Intensive Study Site, four increasingly severe disturbances were created on replicate $6 \times 8 \mathrm{~m}$ plots. The disturbances were:

Treatment 1: Vegetation scraped, topsoil left in place

Treatment 2: Vegetation scraped, topsoil ripped to $30 \mathrm{~cm}$

Treatment 3: Vegetation scraped, topsoil and subsoil mixed to a depth of $1 \mathrm{~m}$

Treatment 4: Vegetation scraped, $1 \mathrm{~m}$ of subsoil placed over topsoil buried $1 \mathrm{~m}$ deep

In 1976, 1977, and 1979 replicate plots (four treatments per plot) were established for observing the effects of initial treatment on the MIP of the soil and how MIP correlates with recovery of natural vegetation on these plots. No additional disturbances occurred following the establishment of each plot. For each treatment in each plot three samples of the top $15 \mathrm{~cm}$ of soil were removed at each sampling date (Nov 1978, Jul 1979, Jul 1980) and composited. The soil was mixed in the lab and a bioassay (Moorman and Reeves 1979) was run for 15 days in a growth chamber $(\mathrm{d} / \mathrm{n} 14 / 10 \mathrm{hr}$, temp $28 / 21^{\circ} \mathrm{C}$, 1 ight approx. $350 \mu \mathrm{E} / \mathrm{m}^{2} / \mathrm{sec}$ ) using pregerminated DeKalb XL 321 corn. 


\section{Results and Discussion}

Although the mean MIP values for Treatments 1-4 tend to decrease with increasing disturbance (Table 18), a one-way ANOVA of MIP vs. treatment for each year $(1978,1979,1980)$ indicates that there are no significant differences $(p<.05)$ between treatments for two years following disturbance. However, after the third year following disturbance significant $(p=.01)$ differences between Treatments $1,2,3$, and 4 in plots disturbed in 1976 and 1977 were obvious (Figures 50 and 51).

Table 18. Mean changes in the MIP of Disturbance plots established in 1976, 1977, and 1979.

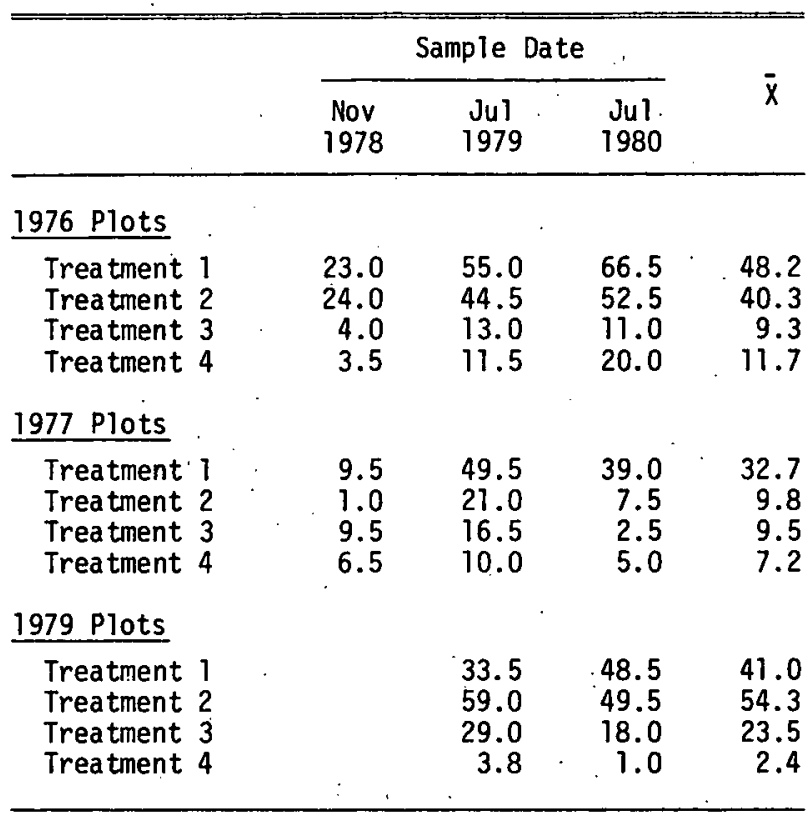

For plots initially disturbed in 1976, Treatments 1 and 2 show much greater recovery from disturbance than the more severely disturbed Treatments 3 and 4 . The MIP values of the soil in these plots reflect this recovery (Table 18, Figure 50).

For plots initially disturbed in 1977, Treatments $1-4$ do not exhibit the rate of recovery found in the plots disturbed in 1976. Similarly, the MIP of the soil (with the exception of the least disturbed treatment, Treatment 1) remains relatively low (Table 18).

Figures 50 and 51 suggest that there may be a certain critical MIP level (typically more than 20 when measured two years after disturbance) which, in conjunction with other factors, is necessary if reasonably rapid MIP recovery is to be expected from disturbed areas. Slow MIP recovery (197.6 plots, Treatments 3 and 4 ; 1977 plots, Treatments 2, 3 , and 4) is typically characterized by an MIP value of 20 or less.

Mean MIP data for the plots disturbed in 1979 (Table 18) indicate a general trend for the less

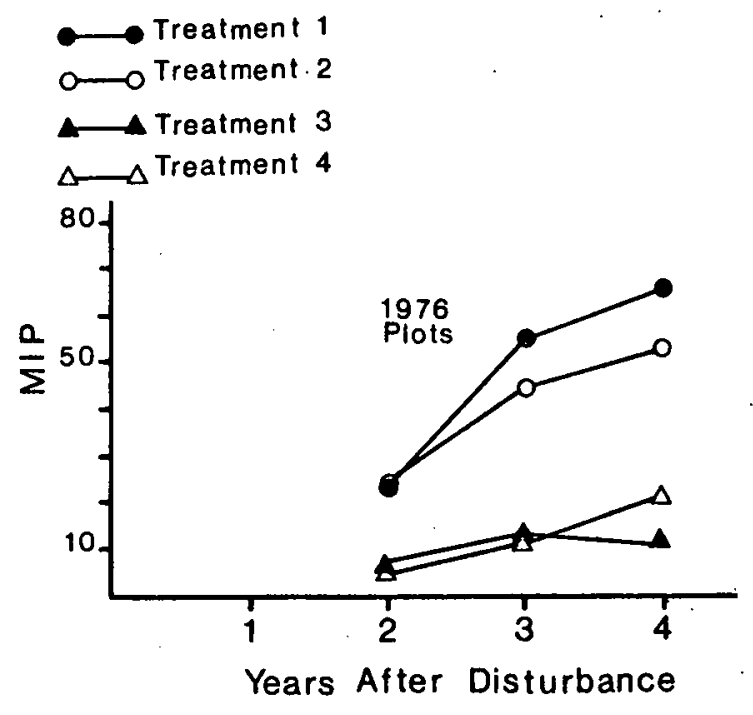

Figure 50. Yearly changes in mean MIP on each treatment of the disturbance plots for plots initially disturbed in 1976.

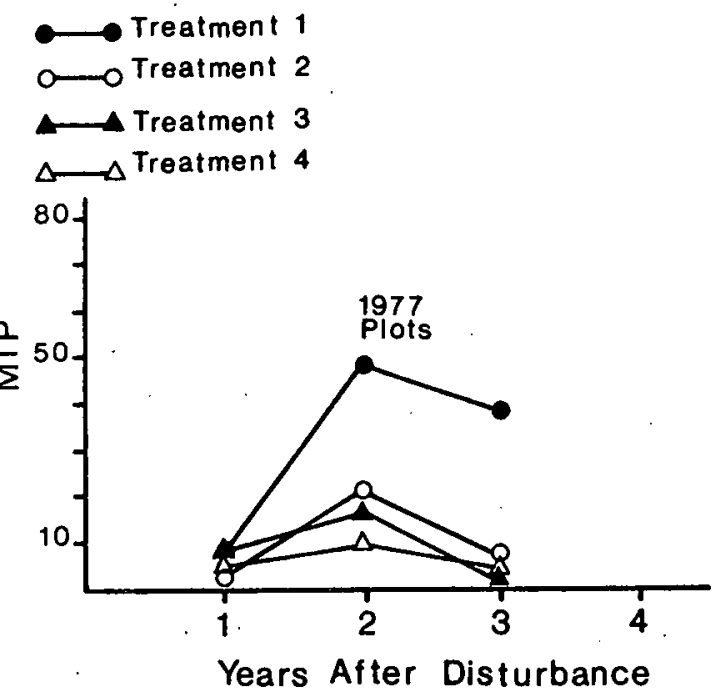

Figure 51. Yearly changes in mean MIP on each treatment of the disturbance plots for plots initially disturbed in 1977.

severely disturbed plots (Treatments 1 and 2) to maintain or increase the MIP of the soil in contrast with the more severely disturbed plots (Treatments 3 and 4 ) where the MIP tends to decline.

For soils initially disturbed in 1976 and 1977 , the average density, biomass, and cover of grasses (data from Redente et al. in this report) and the average MIP for each treatment (Treatments 1-4) are given in Table 19. For each factor measured (density, biomass, cover, or MIP) there is a consistent decrease in value as the degree of initial 
disturbance increases. These data represent averages for three years for the plots disturbed in 1976 and 1977; these data are plotted in Figure 52. Data in Table 19 suggest that when the MIP value averages <10 (Treatments 3 and 4 ) three to four years after disturbance, then minimum increases in density, biomass, and cover of grasses will occur. In contrast, when the MIP averages 25 or more (Treatments 1 and 2) three to four years after disturbance, then plant succession is reasonably rapid as measured by grass biomass, cover, and density.

Table 19. Average (1977-1980) density, biomass, and canopy cover of grasses and MIP on the Disturbance plots initially disturbed in 1976 and 1977.

\begin{tabular}{lcccc}
\hline & \multicolumn{4}{c}{ Treatment } \\
\cline { 2 - 5 } & 1 & 2 & 3 & 4 \\
\hline Density $\left(\# / \mathrm{m}^{2}\right)$ & 38.6 & 12.0 & 1.9 & 0.7 \\
Biomass $(\mathrm{kg} / \mathrm{ha})$ & 583 & 231 & 101 & 5 \\
Cover $(\%)$ & 11.2 & 1.7 & 0.8 & 0.1 \\
MIP & 40.4 & 25.1 & 9.4 & 9.4 \\
\hline
\end{tabular}

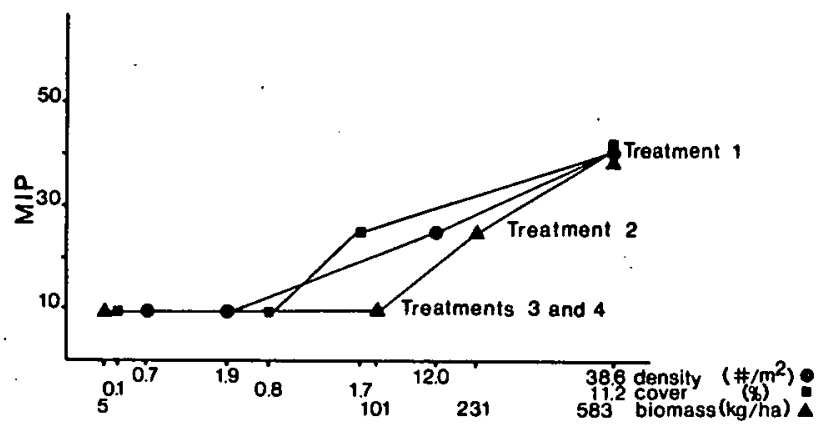

Figure 52. Relationship between the average MIP of the Disturbance plots initially disturbed in 1976 and 1977 and the average density, biomass, and cover of grasses for each treatment.

Comparisons of data in Tables 18 and 19 suggest that when the MIP is $<20$ two years after disturbance (Table 18) or when MIP averages <10 three years or more after disturbance (Table 19), minimal increases in density, biomass, and cover of grasses can be expected. In contrast, when MIP exceeds 20 two years after disturbance (Table 18) or averages $>10$ three years after disturbance (Table 19), establishment of grasses is reasonably rapid as measured by biomass, cover, and density.

When MIP ranges between 10 and 25 (Table 19) three to four years after disturbance, there is a range of recovery which may be a function of additional factors such as the number of viable seeds present, soil moisture, etc.
We are currently attempting to integrate all the years' MIP data with all the years' vegetation data in a computer anlaysis. We hope this effort will more clearly explain the relationship among the various edaphic and mycorrhizal factors and their relative role in succession of native plants.

\section{Long-Term Fertility Plots}

These plots were initiated in 1977 to determine the long-term fertility requirements for establishment and growth of plants on soil over shale. Disturbed topsoil $(61 \mathrm{~cm})$ was placed over Paraho processed oil shale $(61 \mathrm{~cm})$, and a uniform application of $130 \mathrm{~kg} \mathrm{P} /$ ha was broadcast over the plots. Subplots received various nitrogen treatments ranging from 0 to $448 \mathrm{~kg} / \mathrm{ha} / \mathrm{yr}$ or $1793 \mathrm{~kg} / \mathrm{ha}$ or various levels of sewage sludge as an initial application. Each subplot was replicated three times and planted with a mixture of native species. Details of these plots are found in Sabey et al. in this report.

The subplots selected for sampling were those receiving uniform $P$ applications $(130 \mathrm{~kg} / \mathrm{ha})$ and differing inorganic $\mathrm{N}$ applications (Plots 1-8) and a check (control) subplot (Plot 20) with no additional N (Table 20). Sampling (three 15-cm deep, $7.5 \mathrm{~cm}$ wide cores/plot) was done in the early fail of 1980 (0ctober 12) when the numbers of mycorrhizal spores were believed to be highest (Hayman 1975). So il was returned to the lab, and a 2l-day bioassay was run in our growth chambers using the methods described in this report.

Table 20. MIP values of selected Long-Term Fertility Plots (disturbed topsoil over shale.

\begin{tabular}{ccc}
\hline Plot & Nitrogen Treatment & $\begin{array}{c}\text { MIP } \\
\text { Value }\end{array}$ \\
\hline 1 & $56 \mathrm{~kg} / \mathrm{ha} / \mathrm{yr}$ & 73 \\
2 & $112 \mathrm{~kg} / \mathrm{ha} / \mathrm{yr}$ & 54 \\
3 & $224 \mathrm{~kg} / \mathrm{ha} / \mathrm{yr}$ & 28 \\
4 & $448 \mathrm{~kg} / \mathrm{ha} / \mathrm{yr}$ & 26 \\
& & \\
5 & $224 \mathrm{~kg} / \mathrm{ha}$ initial application & 65 \\
6 & $448 \mathrm{~kg} / \mathrm{ha}$ initial application & 74 \\
7 & $896 \mathrm{~kg} / \mathrm{ha}$ initial application & 56 \\
8 & $1792 \mathrm{~kg} / \mathrm{ha}$ initial application & 64 \\
20 & $0 \mathrm{~kg} / \mathrm{ha}$ & 74 \\
\end{tabular}

\section{Results and Discussion}

The specific objective of this subproject for this year was to determine if there are trends of detrimental effects on the MIP. of disturbed topsoil over shale when moderate to high rates of nitrogen fertilizers are added.

As Hayman (1975) has stated, "Quantitative studies on the effects of different fertilizer treatments on mycorrhizal propagules and infection 
in the field are few." Previous results on the effects of added fertilizers are equivocal--some experiments indicate the fertilizers decrease the mycorrhizal population; others indicate the fertilizers increase the populations (Hayman 1975, Gerdemann 1975).

Results from experiments this year (Table 20 , Figure 53) indicate that there are significant $(p<.05)$ differences in MIP between Plots $1-4$ where $N$ fertilizer was added as incremental yearly additions. The addition of 56 or $112 \mathrm{~kg} / \mathrm{ha} / \mathrm{yr}$ (equal to 224 or $448 \mathrm{~kg} / \mathrm{ha}$ total $\mathrm{N}$ over four years) does not significantly alter the MIP of the soil as compared to the control (Panel 20). No significant $(p=.05)$ differences in MIP occur within Plots 5-8 when rather heavy applications of $N$ are added as an initial, single application: In terms of total added N, Plot 1 is equivalent to Plot 5 , Plot $2=$ Plot 6 , Plot $3=$ Plot 7 , and Plot $4=$ Plot 8 .

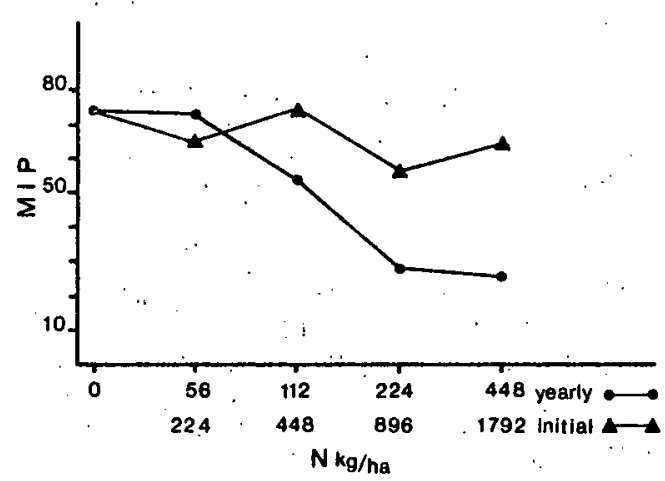

Figure 53. Relationship in 1980 between MIP and the amount of $\mathrm{N}$ fertilizer added to soil as yearly (56-448 kg/ha) additions for four years or as a single addition (224-1792 kg/ha) in 1977.

There appears to be a fundamentally different response between large, initial applications of $\mathrm{N}$ and smaller, incremental additions of $\mathrm{N}$ in terms of their effects on MIP of the soil (Figure 53). However, none of the additions of $N$ reduce the MIP of the soil to a level which appears critically low, i.e. <20 (see "Annual] Disturbance P. lots" in Reeves et ai. of this report).

Next year it is hoped to repeat this study and extend the data to other. subplots and to the LongTerm Fertility subsoil plots.

\section{Conclusions and Recommendations}

The initial application of moderate to heavy (224- $1792 \mathrm{~kg} / \mathrm{ha}$ ) amounts of $\mathrm{N}$ to disturbed topsoil over shale does not significantly affect the MIP of the soil. Yearly applications of $\mathbf{N}$ equivalent to 56 or $112 \mathrm{~kg} / \mathrm{ha}$ do not significantly alter the MIP of the soil. Yearly additions of $N$ equivalent to 224 or $448 \mathrm{~kg} / \mathrm{ha}$ significantly reduce the MIP of disturbed topsoil over shale but not to levels considered to be critically low.
Recommendations are:

1. Add $N$ to disturbed topsoil at yearly intervals up to a total of $112 \mathrm{~kg} / \mathrm{ha}$ as an initial treatment to enhance reclamation procedures. Heavy applications of $\mathrm{N}$ decrease plant production--and heavy yearly. additions ( $>224 \mathrm{~kg} / \mathrm{ha} / \mathrm{yr}$ ) significantly reduce MIP of the soil.

2. Continue to study these plots to determine if there are further reductions in the MIP of the soils with high initial or incremental additions of $N$. Correlate MIP values with success or reclamation procedures and soil analyses done by Dr. Sabey.

3. Extend this study to similarly fertilized subsoil plots to determine if there are comparable changes in the MIP values of the subsoil plots.

\section{Effects of Different Strains of Mycorrhizal Fungi on Growth of Selected Native Plants and Comparative Survival of Native plants Under Field Conditions}

These studies were initiated in 1978 to determine the effects of mycorrhizal fungi on several native species and to establish criteria for selecting the best strains of fungi for inoculating native plant species.

The procedure was to use a native strain of the mycorrhizal fungus Glomus fasciculatus, isolated in the laboratory, as an inoculum and compare growth responses of certain plants (viz., Atriplex canescens, Ceratoides lanata, Artemisia tridentata, Stipa viriduza, and Agropyron smithii) which were grown under different fertilizer conditions. The results of this work are now published (Kiel 1980) and were the basis of the author's M.S. thesis. In another study, the interaction of Glomus and Rhizobium on sweetvetch (Hedysamm boreale) were studied. Results of this work have been accepted for publication (Redente and Reeves 1981).

Currently we have 200 seedlings each of the species western wheatgrass (Agropyron smithii) and big sagebrush (Artemisia tridentata) and 400 seedlings of fourwing saltbush (Atriplex canescens) under study in the greenhouse and in growth chambers which have been inoculated with the following mycorrhizal fungi: native culture of Glomus. fasciculatus, Abbott Lab \#3 culture of $G$. fasciculatus, and Abbott Lab \#8 culture of G. mosseae. Results of these experiments are incomplete. We intend to use the 200 seedlings each of wheatgrass and sagebrush for transpiants into the field in late spring to study growth and survival of these species.

\section{Seasonal Variation in Populations of Mycorrhizal Fungi}

This study was initiated in 1978 to determine if seasonal fluctuations of the MIP occurs in an 
undisturbed sagebrush community at the Intensive Study Site.

Soil (upper $15 \mathrm{~cm}$ ) was collected (Nov 1978 , Mar 1979, Apr 1979, Jul 1980, Oct 1980) from six locations within a $20-\mathrm{m}$ radius, viz., beneath sagebrush plants and in relatively open areas. The soil was returned to the lab, and a bioassay was run for 15 days for each sample in growth chambers using the methods described in this report.

\section{Results and Discussion}

The specific objective of this study was to determine the relative heterogeneity of the mycorrhizal population associated with years and seasons. Such information may be used to determine the time of maximum MIP in the undisturbed soil.

The preliminary results of this work are given in Figure 54 and in Table 21. The highest mean MIP for all sites was in October 1980; the lowest mean MIP recorded was in July 1980. The trends indicate a rather large variation between years of sampling for all sites. Therefore, it appears necessary to correlate weather data, rather than only time of year, with MIP in order to better predict fluctuations in MIP during any given year.

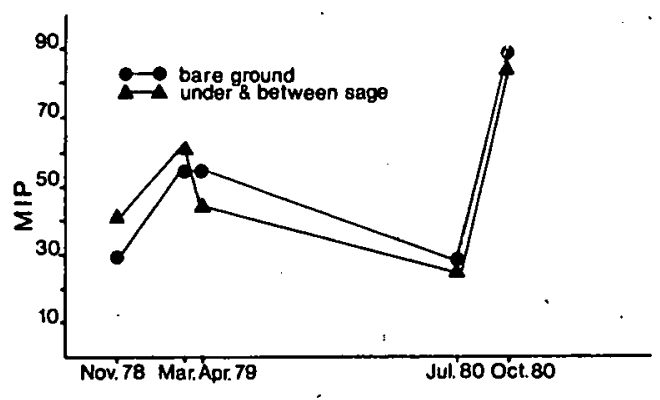

Figure 54. Variation in MIP of soil beneath big sagebrush and soil in bare areas between big sagebrush at different seasons.

Table 21. Seasonal variation in MIP values in an undisturbed big sagebrush community.

\begin{tabular}{|c|c|c|c|c|c|}
\hline Sampling Site & $\begin{array}{l}\text { Nov } \\
1978\end{array}$ & $\begin{array}{c}\text { Mar } \\
.1979\end{array}$ & $\begin{array}{l}\text { Apr } \\
1979\end{array}$ & $\begin{array}{l}\text { Jul } \\
1980\end{array}$ & $\begin{array}{l}\text { Oct } \\
1980\end{array}$ \\
\hline Bare ground & 29 & 54 & 54 & 28 & 88 \\
\hline \multicolumn{6}{|l|}{ Under } \\
\hline $\begin{array}{l}\text { sagebrush } \\
\text { plants }\end{array}$ & 42 & 67 & 51 & 26 & 82 \\
\hline \multicolumn{6}{|l|}{ Between } \\
\hline $\begin{array}{l}\text { sagebrush } \\
\text { plants }\end{array}$ & 40 & 54 & 37 & 29 & 86 \\
\hline Mean values & 37.0 & 58.3 & 47.3 & 27.6 & 85.3 \\
\hline
\end{tabular}

Conclusions and Recommendations

Hayman (1975) reported that populations of viable mycorrhizal propagules were greatest in late summer. Thus far, data from Colorado suggest the numbers are greatest in early fall. Basically, this agrees with observations of other researchers.

Recommendations are:

1. When high MIP values for topsoil are needed, land disturbance should be done in the fall (October). Because intrinsic levels of MIP are at a minimum in mid summer. Disturbance during this period would exert the greatest detrimental effect on the viable populations of mycorrhizal fungi in the soil.

2. Continue to monitor seasonal fluctuations of MIP at the Intensive Study Site and correlate this data with weather data to determine the interactions of seasonal and climatic factors on MIP.

\section{LITERATURE CITED}

Gerdemann, J. W. 1968. Vesicular-arbuscular mycorrhizae and plant growth. Ann. Rev. Phytopath. 6:397-418.

Gerdemann, J. W. 1975. Vesicular-arbuscular mycorrhizae. Pages 575-591 in J. G. Torrey and D. T. Clarkson, eds. The development and function of roots. Academic Press, New York.

Hayman, D. S. 1975. The occurrence of mycorrhiza in crops as affected by soil fertility. Pages 495-509 in F. E. Sanders, B. Mosse, and P. B. Tinker, eds. Endomycorrhizas. Academic Press, New York.

Keeley, J. E. 1980. Endomycorrhizae influence growth of blackgum seedlings in flooded soils. Am. J. Bot. 67:6-9.

Kiel, J. E. 1980. The effects of soil phosphorus on growth and endomycorrhizal development in plant species native to Colorado. Pages 555565 in Charles Galed, ed. Oil Shale Symposium: Sampling, Analysis, and Quality As surance, March 1979. EPA-600/9-80-022. Industrial Environmental Research Laboratory, Cincinnati, Ohio.

Moorman, T., and F. B. Reeves. 1979. The role of endomycorrhizae in revegetation practices in the semi-arid West. II. A bioassay to determine the effect of land disturbance on endomycorrhizal populations. Am. J. Bot. 66:14-18.

Redente, E., and F. B. Reeves. 1981. Interaction between VA mycorrhiza and Rhizobizm and the effect on sweetvetch. Soil Sci. Accepted for publication.

Schwab, S., and F. B. Reeves. 1981. The role of endomycorrhizae in revegetation practices in the semi-arid West. III. Vertical distribution of VA mycorrhizal infection potential. Am. J. Bot. Accepted for publication. 
AVAILABLE PUBLICATIONS AND/OR ABSTRACTS

Reeves, F. B. 1978. The incidence of VA mycorrhizae in a disturbed vs. mid-elevation sage community. AAAS Meet., Albuquerqu, N.M. (Abstr.)

Reeves, F. B. 1978. Ecology of VA mycorrhizal fungi in a semi-arid sage community. Mycol. Soc. Am. Meet., Athens, Ga. (Abstr.)

Reeves, F. B., B. Wagner, T. Mơorman, and J. Kiel. 1979. The role of endomycorrhizae in revegetation practices in the semi-arid West. I. A comparison of incidence of mycorrhizae in severely disturbed vs. natural environments. Am. J. Bot. 66:6-13.

Moorman, T., and F. B. Reeves. 1979. The role of endomycorrhizae in revegetation practices in the semi-arid West. II. A bioassay to determine the effect of land disturbance on endomycorrhizal populations. Am. J. Bot. 66:14-18.

Klein, D. A., L. E. Hersman, and F. B. Reeves. 1979. Storage effects on the microbiological characteristics of surface soils used in oil shale revegetation programs. Annu. Meet., Soc. Range Manage., Feb., Casper, Wyo. (Abstr.)

Reeves, F. B. 1979. The role of mycorrhizal fungi in reclaiming disturbed oil shale lands. EPA 0il Shale Sampling, Analys is and Quality Assurance Symposium, Univ. Denver, Colo. (Abstr.)

Schwab, S., and F. B. Reeves. 1979. The relationship of host plant age to extend of VA mycorrhizal formation in seedlings of seven species native to northwestern Colorado. Fourth N. Am. Conf. Mycorrhiza, 24-28 June. Colo. State Univ., Ft. Collins. (Abstr.)

Schwab, S., and F. B. Reeves. 1979. The effect of retorted oil shale wastes on VA mycorrhizal formation in soil from northwestern Colorado. Fourth N. Am. Conf. Mycorrhiza; 24-28 June. Colo. State Univ., Ft. Collins. (Abstr.)

Reeves, F: B. 1979. Correlations of VA mycorrhizal fungi and semi-arid ecosystem recovery. Fourth N. Am. Conf. Mycorrhiza, 24-28 June. Colo. State Univ., Ft. Collins. (Abstr.).

Reeves, F. B., C. Bishop, and S. Schwab. 1980. Importance of mycorrhizal fungi in revegetating disturbed soils and retorted shale. Pages 3541 in C. W. Cook and E. F. Redente, princ. invest. Reclamation studies on oil shale lands in northwestern Colorado. Progress report for U.S. Dep. Energy. DE-AS02-76EV04018. (Dep. Range Sci., Colo. State Univ., Ft. Collins.) $58 \mathrm{p}$.

Schwab, S., and F. Brent Reeves. 1980. The effect of retorted oil shale on VA mycorrhiza formation in soil from the Piceance Bas in of northwestern Colorado. Pages 566-576 in Charles Gale, ed. 0il Shale Symposium: Sampling, analysis, and quality assurance, March. EPA600/9-80-022. U.S. Environ. Protec. Agency, Indust. Environ. Res. Lab., Cincinnati, Ohio.
Schwab, S., and F. B. Reeves. 1981. The role of endomycorrhizae in revegetation practices in the semi-arid West. III. Vertical distribution of VA mycorrhizal infection potential. Am. J. Bot. Accepted for publication.

Redente, E. F., and F. B. Reeves. 1981. Interaction between VA mycorrhiza and Rhizobium and their effect on sweetvetch growth. Soil. Sci. Accepted for publication.

Reeves, F. B., D. Klein, and E. Redente. 1981. The role of VAM fungi in revegetation--The effects of topsoil storage on viable fungal populations. Fifth N. Am. Conf. on Mycorrhizae, Univ. Laval, Quebec. (Abstr.)

Reeves, F. B., E. Redente, S. Schmidt, and J. Sabaloni. 1981. The role of VAM fungi in revegetation--Effects of processed oil shale on viable populations of VAM fungi. Fifth N. Am. Conf. on Myocrrhizae, Univ. Laval, Quebec. (Abstr.)

Sabaloni, J. K., and F. B. Reeves. 1981. Interrelationships of light and VAM formation in Zea mays. Fifth N. Am. Conf. on Mycorrhizae, Univ. Laval, Quebec. (Abstr.)

Schmidt, S. K., and F. B. Reeves. 1981. The effects of the chenopodiaceous weed Salsola kali on populations of VAM fungi. Fifth N. Am. Conf. on Mycorrhizae, Univ. Laval, Quebec. (Abstr.) 


\title{
LONG-TERM FERTILITY STUDY ON LAND DRASTICALLY DISTURBED BY OIL SHALE DEVELOPMENT
}

\author{
Burns R. Sabey, M. Katherine Corwin, and Ted B. Doerr \\ Department of Agronomy and Department of Range Science \\ Colorado State University \\ Fort Collins, Colorado 80523
}

OBJECTIVES

METHODS

The general objective of this subproject was to determine the long-term fertility requirements and methods of meeting these requirements on nitrogenand phosphorus-deficient soil materials disturbed by oil shale development in northwestern Colorado. More specifically the objective involved comparing the usefulness of adding low to moderate annual applications of inorganic nitrogen fertilizer with that of adding high rates of inorganic nitrogen fertilizer only once at the initiation of the study on plant establishment and growth. Additionally, comparison of the effect on plant establishment and growth of the high rates of nitrogen fertilizer added initially with and without wood wastes was of interest. Other comparisons showing the effect of fertility treatments on plants were the addition of sewage sludge with and without wood wastes and four combinations of nitrogen and phosphorus fertilizer.
The long-term fertility study was established on the Intensive Study Site in the summer and fall of 1977 to determine the fertility requirements and methods of meeting the requirements of nitrogenand phosphorus-deficient soils. The.study was split into disturbed subsoil and disturbed topsoil studies because they are common plant growth media that may be used in revegetation. The topsoil study was constructed with $61 \mathrm{~cm}$ of topsoil material that was mixed thoroughly and placed over compacted Paraho retorted shale. The subsoil study was constructed using $1.2 \mathrm{~m}$ of subsoil over topsoil.

In each study three replicates were established with 19 treatment plots and one control plot per replicate. The treatments included levels of annually applied nitrogen (N), single applications of $N$, wood waste with $N$, sewage sludge, and $N$ and phosphorus $(P)$ combined as a single application when the plots were initially drill seeded (Table 22).

Rodent and lagomorph damage was extensive on the topsoil study during the winter of 1978-1979. The

Table 22. Species mixture and seeding rates used on the Long-Term Fertility plots.

\begin{tabular}{|c|c|c|c|c|c|}
\hline$\cdot$ & Common Name & & . & Scientific Name & $\begin{array}{l}\text { Seeding } \\
\text { Rate } \\
\mathrm{PL} \cdot \mathrm{S} \\
(\mathrm{kg} / \mathrm{ha})\end{array}$ \\
\hline $\begin{array}{l}1 . \\
2 . \\
3 . \\
4 . \\
5 . \\
6 . \\
7 . \\
8 . \\
9 . \\
10 . \\
11 . \\
12 . \\
13 . \\
14 . \\
15 . \\
16 .\end{array}$ & $\begin{array}{l}\text { Rosana western wheatgrass } \\
\text { Sodar streambank wheatgrass } \\
\text { Bearded bluebunch wheatgrass } \\
\text { Indian ricegrass } \\
\text { Green needlegrass } \\
\text { Durar hard fescue } \\
\text { Shermans big bluegrass } \\
\text { Alkali sacaton } \\
\text { Globemallow } \\
\text { Sweetvetch } \\
\text { Palmer penstemon } \\
\text { Stansbury cliffrose } \\
\text { Green ephedra. } \\
\text { Fourwing saltbush } \\
\text { Winterfat } \\
\text { Antelope bitterbrush }\end{array}$ & 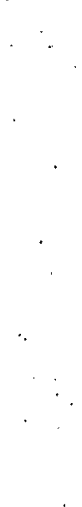 & $\begin{array}{l}. \\
. \\
.\end{array}$ & $\begin{array}{l}\text { Agropyron smithii } \\
\text { Agropyron riparizom } \\
\text { Agropyron spicatum } \\
\text { Oryzopsis hymenoides } \\
\text { Stipa viridula } \\
\text { Festuca ovina duriuscula } \\
\text { Poa ampla } \\
\text { Sporobolus airoides } \\
\text { Sphaeralcea murroana } \\
\text { Hedysarm boreale } \\
\text { Penstemon palmeri } \\
\text { Cowania mexicana stansburiana } \\
\text { Ephedra viridis } \\
\text { Atriplex canescens } \\
\text { Ceratoides lanata } \\
\text { Purshia tridentata }\end{array}$ & $\begin{array}{l}1.12 \\
1.12 \\
1.12 \\
1.12 \\
1.12 \\
0.56 \\
1.12 \\
0.56 \\
0.56 \\
1.12 \\
0.56 \\
2.24 \\
1.12 \\
1.12 \\
1.12 \\
1.12\end{array}$ \\
\hline
\end{tabular}


plot was therefore reseeded in May 1979. The seedbed was prepared using a chisel plow with two alternate rows of chisels $20 \mathrm{~cm}$ apart. The area was chiseled once perpendicular to the original seed rows. All plots were broadcast seeded with a native seed mix (Table 22). The seed was broadcasted and covered by dragging a weighted chain-link fence over the plots. Approximately $15 \mathrm{~cm}$ of water were applied over six weeks during the spring and summer of 1979.

Soil samples were obtained in the spring of 1978,1979 , and 1980 from the topsoil and subsoil fertility plots. In 1978 the soil in both studies was sampled using an 0akfield probe $2 \mathrm{~cm}$ in diameter. Twenty cores $30 \mathrm{~cm}$ deep were obtained at random locations within each treatment plot. These cores were composited and air-dried in preparation for further analysis.

In 1979 and 1980 the composite samples consisted of 10 cores per treatment plot from both studies as described above. The topsoil over retorted shale study was sampled at two depths, $0-30 \mathrm{~cm}$ and $30-60$ $\mathrm{cm}$. The sampling depth stopped at the soil-retorted shale interface. The underlying shale was not sampled.

The soil samples were analyzed each year for electrical conductivity, $\mathrm{pH}, \mathrm{NH}_{4}^{+}-\mathrm{N}, \mathrm{NO}_{3}^{-}-\mathrm{N}$, total nitrogen, and extractable phosphorus. Soils were air-dried and ground to pass through a 2-mm sieve prior to analysis.

The $\mathrm{pH}$ was determined in a saturated soil paste, and electrical conductivity was determined on the filtered saturation extract using a conductivity meter and reported in mohos $/ \mathrm{cm}$.

Ammonium $\left(\mathrm{NH}_{4}^{+}-\mathrm{N}\right)$ was measured in a potassium chloride extract with an ammonium electrode and reported in ppm. Nitrate $\left(\mathrm{NO}_{3}^{-}-\mathrm{N}\right)$ was determined by the phenoldisulfonic acid method and reported in $\mathrm{ppm}$. Extractable phosphorus was measured using the 01 sen bicarbonate method which was suitable for high $\mathrm{pH}$ soils and was reported in ppm. Total nitrogen was measured by a block digestion-distillation method and reported as percent total nitrogen in air-dried soil.

The potassium chloride extract-distillation method of Bremner (1965) was used to determine both $\mathrm{NH}_{4}^{+}-\mathrm{N}$ and $\mathrm{NO}_{3}^{-}-\mathrm{N}$. Total nitrogen was measured with a block digest-Technicon Autoanalyzer method (Technicon Industrial Systems 1977).

Selected samples from 1978 and 1979 were reanalyzed in 1980 to determine analytical differences due to method and technician. The results obtained in 1980 compared favorably with results obtained in 1978 and 1979 on the same soil samples.

Vegetation was sampled using six permanent $0.25-\mathrm{m}^{2}$ quadrats placed randomly in each plot. Density, biomass, and canopy cover were measured by species during the peak of the growing season in each succeeding year following planting. The study was broken down into five divisions (Table 23). Data were analyzed using analysis of variance for 1980 field data. Sheffe's multiple range test was used for mean separation. It must be understood that because of unexpected disturbance (i.e., rodent damage and subsequent reseeding in 1979) the results and discussion that follow concerning topsoil data
Table 23. Fertilizer treatments for the five substudies of the topsoil fertility study.

\begin{tabular}{|c|c|}
\hline $\begin{array}{l}\text { Treatment } \\
\text { Number }\end{array}$ & Fertilizer Treatment \\
\hline & Annual Rates of $\mathrm{N}^{\dagger}$ \\
\hline \multirow[t]{2}{*}{$\begin{array}{l}1 \\
2 \\
3 \\
4\end{array}$} & $\begin{array}{l}56 \mathrm{~kg} \text { N/ha applied annually for a four-year period } \\
112 \mathrm{~kg} N / \mathrm{ha} \text { applied annualiy for a four-year period } \\
224 \mathrm{~kg} N / \mathrm{ha} \text { applied annually for a four-year period } \\
448 \mathrm{~kg} \text { N/ha applied annually for a four-year period }\end{array}$ \\
\hline & Single Rates of $N$ \\
\hline \multirow[t]{2}{*}{$\begin{array}{l}5 \\
6 \\
7 \\
8\end{array}$} & $\begin{array}{r}224 \mathrm{~kg} \mathrm{~N} / \mathrm{ha} \text { in a single application } \\
448 \mathrm{~kg} \mathrm{~N} / \mathrm{ha} \text { in a single application } \\
896 \mathrm{~kg} \mathrm{~N} / \mathrm{ha} \text { in a single application } \\
1,792 \mathrm{~kg} \mathrm{~N} / \mathrm{ha} \text { in a singla application }\end{array}$ \\
\hline & Single Rates of $N$ as Above Plus Hood Hastes (ww) \\
\hline \multirow[t]{2}{*}{$\begin{array}{r}9 \\
10 \\
11 \\
12\end{array}$} & 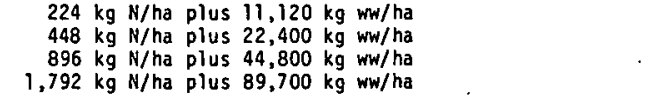 \\
\hline & Sewage Sludge (ss) Plus ww \\
\hline \multirow[t]{2}{*}{$\begin{array}{l}13 \\
14 \\
15\end{array}$} & $\begin{array}{l}56,000 \mathrm{~kg} \mathrm{ss} / \mathrm{ha} \\
112,000 \mathrm{~kg} \mathrm{ss} / \mathrm{ha} \text { plus } 22,400 \mathrm{~kg} \mathrm{ww} / \mathrm{ha} \\
224,000 \mathrm{~kg} \mathrm{ss} / \mathrm{ha} \text { plus } 44,800 \mathrm{~kg} \mathrm{ww} / \mathrm{ha}\end{array}$ \\
\hline & $\mathrm{P}^{\$}$ and $\mathrm{N}$ Interaction \\
\hline \multirow[t]{2}{*}{$\begin{array}{l}16 \\
17 \\
18 \\
19\end{array}$} & $\begin{array}{l}896 \mathrm{~kg} \mathrm{~N} / \mathrm{ha} \text { plus } 56 \mathrm{~kg} \mathrm{P} / \mathrm{ha} \text { in a single application } \\
112 \mathrm{~kg} \mathrm{~N} / \mathrm{ha} \text { plus } 192 \mathrm{~kg} \mathrm{P} / \mathrm{ha} \text { in a single application } \\
896 \mathrm{~kg} \mathrm{~N} / \mathrm{ha} \text { plus } 192 \mathrm{~kg} \mathrm{P} / \mathrm{ha} \text { in a single application } \\
112 \mathrm{~kg} \mathrm{~N} / \mathrm{ha} \text { plus } 56 \mathrm{~kg} \mathrm{P} / \mathrm{ha} \text { in a single application }\end{array}$ \\
\hline & Control \\
\hline 20 & $130 \mathrm{~kg} \mathrm{P} / \mathrm{ha}$ \\
\hline
\end{tabular}

must be interpreted with caution. The effect of rodent damage and subsequent plowing and seeding may still be confounding the results to some degree.

\section{RESULTS AND DISCUSSION}

\section{Soil Data for Subsoil Plots}

In 1980 electrical conductivity was low in all treatments (Table 24). and not significantly different from the control. Where the highest rate of annual nitrogen was applied, an electrical conductivity of $1.3 \mathrm{mmhos} / \mathrm{cm}$ was measured which was significantly higher than the control level of 1.1. However, this level was not elevated enough to have detrimental effects upon plant growth. Most plants, with the exception of some very salt-sensitive species, do not show appreciable salt-effect symptoms until the electrical conductivity is greater than $4 \mathrm{mmhos} / \mathrm{cm}$ (U.S. Salinity Laboratory Staff 1954). Average electrical conductivity over all trea tments decreased from $1.5 \mathrm{mmhos} / \mathrm{cm}$ in 1978 to 0.5 mmos/cm in 1979 and then increased to 1.0 mmhos/ $\mathrm{cm}$ in 1980. These yearly fluctuations reflect the redistribution of soluble salts in the soil as plants remove nutrients, as water moves in the soil, and as the soil minerals approach equilibrium. 
Table 24. Subsoil fertility parameters for 1980 as influenced by treatments shown in Table 23.

\begin{tabular}{|c|c|c|c|c|c|c|}
\hline \multirow[b]{2}{*}{$\begin{array}{c}\text { Fertilizer } \\
\text { Treatment } \\
\text { Number } \\
.\end{array}$} & \multicolumn{6}{|c|}{ Paranetert } \\
\hline & 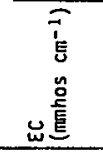 & II & 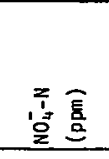 & 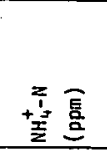 & $\begin{array}{l}z \\
5 \\
80\end{array}$ & 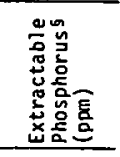 \\
\hline 1 & $0.73^{\mathrm{ab}}$ & $8.3^{\mathrm{C}}$ & $4.3^{\mathrm{a}}$ & $2.8^{\mathrm{abc}}$ & $0.036^{a}$ & $43.2 \mathrm{de}$ \\
\hline 2 & $0.83^{\mathrm{ab}}$ & $8.1^{a b}$ & $4.7^{\mathrm{a}}$ & $5.5^{\mathrm{abc}}$ & $0.042^{\mathrm{a}}$ & $36.5^{\mathrm{bcd}}$ \\
\hline 3 & $0.87^{\mathrm{ab}}$ & $8.1^{a b}$ & $17.6^{\circ}$ & $1.8^{\mathrm{ab}}$ & $0.039^{\mathrm{a}}$ & $28.2^{\mathrm{abc}}$ \\
\hline 4 & $1.33^{\mathrm{c}}$ & $7.8^{\mathrm{a}}$ & $37.4^{\mathrm{C}}$ & $5.3^{a b c}$ & $0.038^{\mathrm{a}}$ & $25.9^{\mathrm{ab}}$ \\
\hline 5 & $0.67^{a b}$ & $8.3^{\mathrm{ab}}$ & $1.7^{\mathrm{a}}$ & $3.7^{\mathrm{abc}}$ & $0.037^{\mathrm{a}}$ & 35.9 bed \\
\hline 6 & $0.70^{\mathrm{ab}}$ & $8.2^{\mathrm{ab}}$ & $1.4^{\mathrm{a}}$ & $3.0^{\mathrm{abc}}$ & $0.038^{\mathrm{a}}$ & $33.2^{\mathrm{abcd}}$ \\
\hline 7 & $0.60^{\mathrm{ab}}$ & $8.3^{a b}$ & $1.4^{\mathrm{a}}$ & $4.1^{a b}$ & $0.033^{\mathrm{a}}$ & $31.5^{\mathrm{abcd}}$ \\
\hline 8 & $0.63^{a b}$ & $8.1^{a b}$ & $4.9^{a}$ & $1.6^{\mathrm{ab}}$ & $0.037^{a}$ & $26.6^{\mathrm{abc}}$ \\
\hline 9 & $0.77^{\mathrm{ab}}$ & $8.2^{\mathrm{ab}}$ & $2.5^{\mathrm{a}}$ & $1.1^{a b}$ & $0.038^{a}$ & $32.6^{\mathrm{abcd}}$ \\
\hline 10 & $0.60^{\mathrm{ab}}$ & $8.1^{a b}$ & $1.9^{\mathrm{a}}$ & $9.1 \mathrm{c}$. & $0.049^{a}$ & $26.7^{\mathrm{a} b c}$ \\
\hline 11 & $0.57^{\mathrm{ab}}$ & $8.1^{a b}$ & $2.1^{a}$ & $3.0^{\mathrm{abc}}$ & $0.043^{\mathrm{a}}$ & $26.0^{\mathrm{abc}}$ \\
\hline 12 & $0.50^{\mathrm{a}}$ & $8.0^{a b}$ & $2.1^{a}$ & $4.8^{a b c}$ & $0.045^{a}$ & $22.6^{\mathrm{ab}}$ \\
\hline 13 & $0.73^{\mathrm{ab}}$ & $8.0^{\mathrm{ab}}$ & $4.8^{\mathrm{a}}$ & $0.5^{\mathrm{a}}$ & $0.052^{\mathrm{a}}$ & 45.2 \\
\hline 14 & $0.73^{a b}$ & $8.0^{a b}$ & $3.7^{\mathrm{a}}$ & $2.6^{\mathrm{abc}}$ & $0.072^{\mathrm{a}}$ & 35.2 bcd \\
\hline 15 & $0.90^{\mathrm{ab}}$ & $7.9^{a b}$ & $4.1^{\mathrm{a}}$ & $4.6^{a b c}$ & $0.085^{\mathrm{a}}$ & 53.7 \\
\hline 16 & $0.60^{\mathrm{ab}}$ & $8.2^{a b}$ & $2.8^{\mathrm{a}}$ & $0.5^{\mathrm{a}}$ & $0.150^{\mathrm{a}}$ & $19.5^{a}$ \\
\hline 17 & $0.63^{\mathrm{ab}}$ & $8.0^{a b}$ & $3.5^{\mathrm{a}}$ & $7.5^{b c}$ & $0.040^{\mathrm{a}}$ & $20.9^{a}$ \\
\hline 18 & $0.63^{a b}$ & $8.3^{a b}$ & $2.3^{\mathrm{a}}$ & $3.2^{a b c}$ & $0.041^{\mathrm{a}}$ & 40.2 cde \\
\hline 19 & $0.57^{\mathrm{ab}}$ & $8.2^{\mathrm{ab}}$ & $2.3^{\mathrm{a}}$ & $3.0^{a b c}$ & $0.043^{\mathrm{a}}$ & $28.1^{a b c}$ \\
\hline 20 & $1.13^{\mathrm{ab}}$ & $8.2^{a b}$ & $0.7^{\mathrm{a}}$ & $1.9^{\mathrm{ab}}$ & $0.034^{\mathrm{a}}$ & $36.5^{\text {bcd }}$ \\
\hline${ }_{\operatorname{Min}}^{\bar{x}}$ & $\begin{array}{l}0.74 \\
0.40 \\
2.20\end{array}$ & $\begin{array}{l}8.1 \\
7.8 \\
8.6\end{array}$ & $\begin{array}{r}5.3 \\
0.8 \\
39.2\end{array}$ & $\begin{array}{r}3.5 \\
0.0 \\
13.0\end{array}$ & $\begin{array}{l}0.050 \\
0.027 \\
0.374\end{array}$ & $\begin{array}{l}32.4 \\
16.6 \\
56.1\end{array}$ \\
\hline
\end{tabular}

theans within columns followed by the same letter are not statisticaliy significant at the .05 level.

5Phosphorus determined by the 01 sen's sodium bicarbonate extractable method (Watanabe and 01 sen 1965).

Fertilizer treatments, generally, had little effect upon $\mathrm{pH}$ in 1980 (Table 24). The highest annual rate of anmonium-nitrate $\left(\mathrm{NH}_{4} \mathrm{NO}_{3}\right)$ (Treatment 4) resulted in the lowest $\mathrm{pH}(7.8)$ which could be explained by the formation. of nitric acid ( $\mathrm{HNO}_{3}$ ) in the soil as a result of the dissociation of the $\mathrm{NH}_{4} \mathrm{NO}_{3}$ in solution.

Phosphorus generally decreased over time in the soil in all plots. This decrease in extractable phosphorus was expected in these soils due to the equilibrium level of phosphorus that might be maintained at these $\mathrm{pH}$ levels.

As in previous years, $\mathrm{NH}_{4}^{+}-\mathrm{N}$ and $\mathrm{NO}_{3}^{-}-\mathrm{N}$ were generally low, below 5 ppm each (Table 24). The only treatments which showed increased levels of plant-available nitrogen were the two highest annual rates of nitrogen; $224 \mathrm{~kg} \mathrm{~N} / \mathrm{ha}$ and $448 \mathrm{~kg} \mathrm{~N} / \mathrm{ha}$ (Treatments 3 and 4 ), which measured 17.6 and 37.4 ppm of $\mathrm{NO}_{3}^{-}-\mathrm{N}$, respectively, in the soil. Ammonium in these two treatments was not greater than the control. This indicated that nitrification

$$
\mathrm{NH}_{4}^{+} \frac{\text { soil }}{\text { microorganisms }} \mathrm{NO}_{3}^{-}
$$

occurred, resulting in lower $\mathrm{NH}_{4}^{+}$levels. These levels of plant-available nitrogen indicated that the only fertilizer treatments presently supplying levels of plant-available nitrogen above that found in the control were the two highest levels of annually applied nitrogen. This indicated that most of the $\mathrm{NH}_{4} \mathrm{NO}_{3}$ fertilizer applied was not effective in increasing the level of nitrogen available to plants in these soils.

After three years, most of the nitrogen applied in Treatments 5-8 had been lost, thus precluding plant utilization. This loss can be explained by ammonia $\left(\mathrm{NH}_{3}\right)$ volatilization, nitrate leaching, denitrification, and/or other mechanisms (Power 1965, Power and Alessi 1971, Power et a1. 1973, Power 1977, Power 1980). Total nitrogen values (Table 24) showed no significant differences due to fertilizer treatments.

Fertility parameters in plots that had received annual rates of nitrogen for the past three years showed effects from rates of nitrogen applied. Soil $\mathrm{pH}$ (Figure 55) decreased as the rate of $\mathrm{NH}_{4} \mathrm{NO}_{3}$ applied increased. In 1980 the $\mathrm{pH}$ resulting from $56 \mathrm{~kg} \mathrm{~N} / \mathrm{ha}$ applied annually was not different from the control. However, at all other rates of annually applied nitrogen the $\mathrm{pH}$ was lower than the $\mathrm{pH}$ of the control after three years and the highest rate of nitrogen resulted in a significantly lower $\mathrm{pH}$ than the control. This effect upon $\mathrm{pH}$ from the annually applied nitrogen treatments was a result of the acid end-products that formed upon the dissolution and dissociation of $\mathrm{NH}_{4} \mathrm{NO}_{3}$ in soil, the nitrification of $\mathrm{NH}_{4}^{+}-\mathrm{N}$ by soil microorganisms, and the formation of nitric acid in the soil.

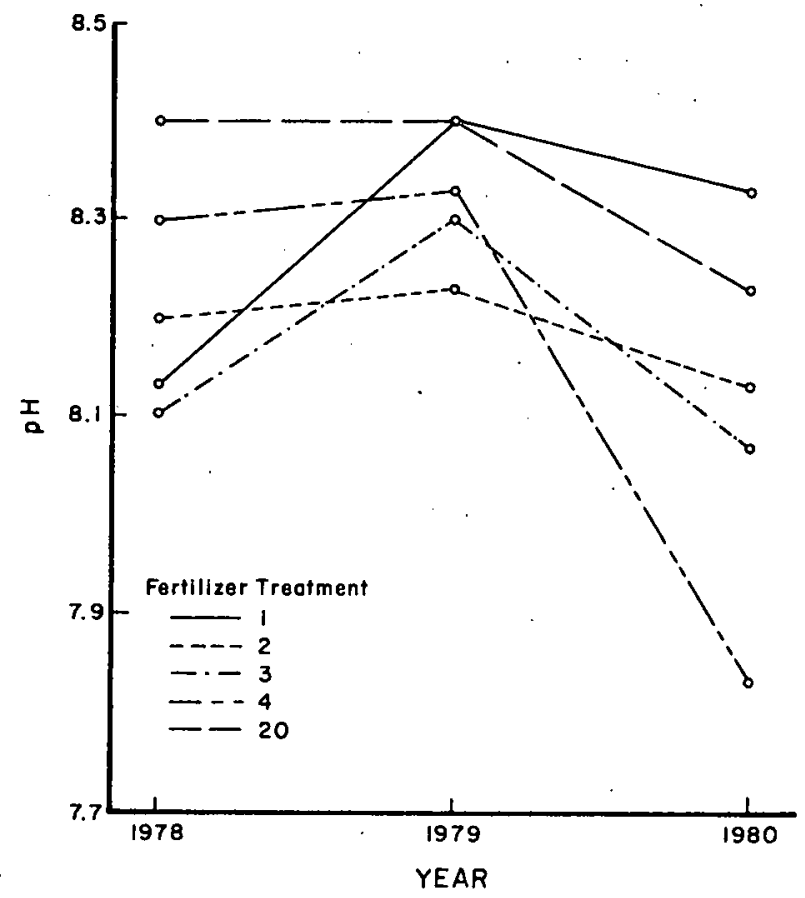

Figure 55. Effect of annually applied $\mathrm{N}$ on $\mathrm{pH}$ over three years for the subsoil study plots. 
The $\mathrm{pH}$ of 7.8 measured in the plot which received $448 \mathrm{~kg} \mathrm{~N} / \mathrm{ha}$ applied annually was not low enough to adversely affect most plant growth. It may have a beneficial effect in the years to come by increasing the solubility of nutrients in the soil, notably phosphorus.

A net accumulation of $\mathrm{NO}_{3}^{-}-\mathrm{N}$ was measured in the top $30 \mathrm{~cm}$ of soil over three years (Figure 56) in these plots. Significantly higher amounts of $\mathrm{NO}_{3}^{-}-\mathrm{N}$ were measured in plots receiving the two highest rates (224 and $448 \mathrm{~kg} / \mathrm{ha}$ ) of nitrogen each year than in the control plots. This accumulation was probably a result of the conversion of $\mathrm{NH}_{4}^{+}-\mathrm{N}$ to $\mathrm{NO}_{3}^{-}-\mathrm{N}$ by soil microorganisms.

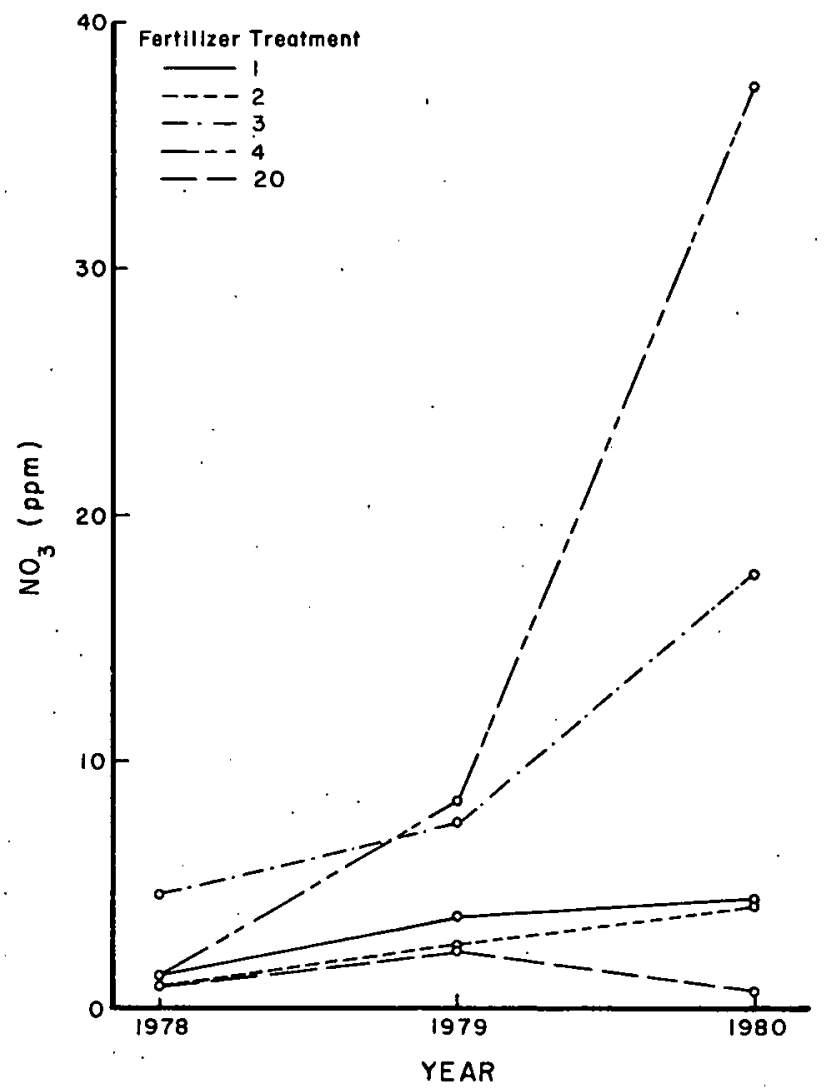

Figure 56. Effect of annually applied $\mathrm{N}$ on $\mathrm{NO}_{3}^{-}-\mathrm{N}$ in the soil over three years for the subsoil study plots.

In contrast to the net accumulation of $\mathrm{NO}_{3}^{-}-\mathrm{N}$ in these plots, $\mathrm{NH}_{4}^{+}-\mathrm{N}$ decreased from $24 \mathrm{ppm}$ in 1978 to $4 \mathrm{ppm}$ in 1980. This reflected the conversion of $\mathrm{NH}_{4}^{+}-\mathrm{N}$ to $\mathrm{NO}_{3}^{-}-\mathrm{N}$. There was no difference in the level of $\mathrm{NH}_{4}^{+}-\mathrm{N}$ in the soil due to the level of nitrogen applied annually.

The treatments which added large amounts of nitrogen initially (Treatments 5-8 and 9-12) with and without wood wastes have had little effect upon soil fertility parameters after three years

(Table 24). Nitrogen was apparently lost from the incorporation zone of the soil-plant system when these high rates were added.

In the first year after application, levels of $\mathrm{NH}_{4}^{+}-\mathrm{N}$ were significantiy higher than in the control plot. However, after three years (1980) the levels of $\mathrm{NH}_{4}^{+}-\mathrm{N}$ in the soil for all of the high initial rates both with and without wood wastes were not significantly higher than in the control plot (Figure 57). Levels of $\mathrm{NO}_{3}^{-}-\mathrm{N}$ after three years were also not significantly higher in any of these treatments than in the control (Table 24). These low levels of plant-available nitrogen left in the soil indicated a large loss of nitrogen from the soil system. This loss cannot be accounted for by plant uptake.

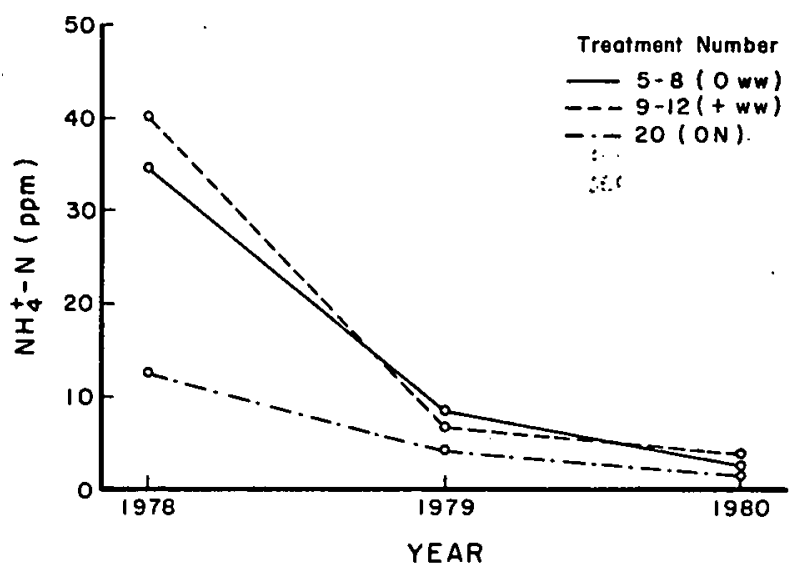

Figure 57. Effect of applying high initial rates of $N$ with and wi thout adding wood wastes on $\mathrm{NH}_{4}^{+}-\mathrm{N}$ after three years in the subsoil plots.

The sewage sludge treatments decreased $\mathrm{pH}$ much like the annually applied nitrogen treatments compared to control plots (Table 24). It also decreased more as higher rates of sludge were added. In 1980 the plot receiving the highest application rate of sludge had a $\mathrm{pH}$ value of 7.9 which was very similar to Treatment 4 in 1980 where $448 \mathrm{~kg} \mathrm{~N} / \mathrm{ha}$ were applied annually. This effect was probably a result of the decomposition of organic matter: in the sludge which released organic acids to lower $\mathrm{pH}$.

The $\mathrm{NO}_{3}^{-}-\mathrm{N}$ and $\mathrm{NH}_{4}^{+}-\mathrm{N}$ levels in plots where sludge was applied showed trends similar to those seen where nitrogen was applied annually. From 1978 to $1980, \mathrm{NO}_{3}^{-}-\mathrm{N}$ accumulated over time while $\mathrm{NH}_{4}^{+}-\mathrm{N}$ decreased from $30 \mathrm{ppm}$ to less than $10 \mathrm{ppm}$.

Applications of sludge were the only treatments where detectable differences in total soil nitrogen occurred as a result of treatments and time. Higher levels of total nitrogen were measured in the two highest rates of sludge each year, although from 1979 to 1980 the level of total nitrogen dropped from $0.08 \%$ to $0.07 \%$ in the higher treatment rates. 
The higher levels of total nitrogen were detected because the sludge was high in organic matter and organic nitrogen, which was included in the total nitrogen analysis. This form of nitrogen was more stable in the soil than plant-available nitrogen. The organic forms of nitrogen were converted to plant-available nitrogen slowly as soil microorganisms decomposed organic nitrogen, producing $\mathrm{NH}_{4}^{+-}-\mathrm{N}$ as a by-product of metabolism. It is highly probable that the sludge will continue to maintain elevated levels of plant-available nitrogen for some time.

The highest level of sewage sludge treatments had a significant effect upon the levels of extractable phosphorous in the soil (Table 24). Since 1979, levels of extractable phosphorus in Treatment 15 were higher than those measured in any treatment plot, including plots where $192 \mathrm{~kg} \mathrm{P} / \mathrm{ha}$ was initially applied. The level of extractable phosphorus maintained by this treatment had decreased very slightly (from $56 \mathrm{ppm}$ to $53 \mathrm{ppm}$ ) over three years. The phosphorus supplied by the sewage sludge was in various organic forms. This phosphorus became available mainly through microbial decomposition. The level of phosphorus that could be maintained from these forms was not as $\mathrm{pH}$ dependent as the form applied as phosphorus fertilizer (triple superphosphate).

The effects of the two rates of nitrogen and phosphorus on soil nitrogen were similar to those described for the plots receiving nitrogen only at the beginning of the study (Treatments 5-8 and 9-12). Levels of extractable phosphorus were lower than the control plot (which received $130 \mathrm{~kg} \mathrm{P/ha)}$ when $56 \mathrm{~kg} P /$ ha were applied (Table 24). Levels of phosphorus were higher in Treatment $18(192 \mathrm{~kg} \mathrm{P} / \mathrm{ha})$ compared to control plots. Treatment 17, which received the same amount of phosphorus as Treatment 18 , had significantly lower amounts of phosphorus compared to Treatment 18 and the control.

\section{Vegetation Data for Subsoil Plots}

Soll fertility data partially explained the variation of vegetation responses. Levels of $\mathrm{NH}_{4}^{+}-\mathrm{N}$ explained $31 \%$ and $11 \%$ of grass and shrub biomass variation, respectively. Generally, $\mathrm{NH}_{4}^{+}-\mathrm{N}$ levels decreased as biomass increased. Electrical conductivity explained $53 \%, 17 \%$, and $13 \%$ of the variation in the cover of grasses; forbs, and shrubs, respectively. Electrical conductivity also explained $8 \%$ of the variation in grass biomass measurements. Total $r^{2}$ values explained between $14.7 \%$ and $58.7 \%$ of the variation in vegetation from 1978 to 1980. Therefore, other factors besides soil fertility were acting on the vegetation.

The biomass and cover of grasses of Treatments 1-4 (annually applied $N$ ) was greater than the control, but the biomass decreased with each increment of additional nitrogen (Table 25). Biomass and cover of forbs and shrubs were less than the control for the first four treatments where nitrogen was applied annually. This is expected somewhat since the forbs and shrubs do not appear to show the response to fertilizer that occurs in grasses. In fact, it appears that forbs and shrubs generally respond in direct contrast to grasses because of the aggressive nature and competition of grasses with young forb and shrub plants during establishment.

Single applications of $N$ (Treatments $5-8$ ) also produced greater biomass of grasses compared to control plots. However, the highest rates, 896 and $1792 \mathrm{~kg} \mathrm{~N} / \mathrm{ha}$ (Treatments 7 and 8), generally had lower forb and shrub biomass and cover compared to control treatments. This caused a general lowering of total biomass and cover of these high application rates (Table 25). Also, the shrub biomass and cover in Treatment 8 may not accurately reflect the true shrub production of this treatment.

Applications of $\mathrm{N}$ with wood waste (Treatments 9-12) had higher grass biomass compared to control plots (Table 25). Forbs were significantly lower in the $\mathrm{N}$ plus wood waste plots compared to the control. Only the lowest $\mathrm{N}$ with wood waste treatment (Treatment 9) produced significantly greater shrub biomass compared to the control plot. As the amount of $\mathrm{N}$ plus wood waste increased, the biomass and cover of vegetation decreased due to a burning of seedlings.

Biomass and cover of grasses, forbs, and total vegetation was less in the $N$ with wood waste plots (Treatments 9-12) compared to the single rates of $N$ (Treatments $5-8$ ) (Table 25). Shrub biomass and cover generally was greater in the $\mathrm{N}$ plus wood waste compared to single rates of $N$. This shrub increase appears to be due to less competition from grasses and shrubs.

Sewage sludge treatments applied with wood waste (Treatments 13-15) had significantly greater grass biomass compared to the control plot. However, only Treatment 14 had greater total vegetation production compared to the control plot. Sewage sludge alone (Treatment 13) or very high rates of sewage sludge applied with wood wastes (Treatment 15 ) appeared to have a negative effect on shrub growth. Therefore, moderate rates of sewage sludge and wood waste (Treatment 14) appear to be a more optimum fertilizer treatment for shrub production. Also, Treatment 14 had higher grass production compared to Treatments 13 and 15 . Sewage sludge alone (Treatment 13) had a similar amount of $\mathrm{N}$ applied as did Treatment $5(224 \mathrm{~kg} \mathrm{~N} / \mathrm{ha})$. The average production was similar in both treatments. However, shrub production in Treatment 5 was almost twice that found in the sewage sludge treatment. This provided the difference in total production. Apparently sewage sludge on subsoils did not contribute more as a soil amendment than did commercial $N$ (Treatment 5 ). Comparable amounts of wood waste and available N/ha were added to Treatments 10 and 11 compared to Treatments 14 and 15. Sewage sludge with wood wastes (Treatments 14 and 15) produced more grass than did commercial $N$ with wood waste (Treatments 10 and 11). However, variations in forb and shrub production allowed total production of the commercial $\mathrm{N}$ with wood waste treatments to be similar to sewage sludge with wood waste treatments (Table 23). Nevertheless, Treatment 14 still had greater total production.

Treatments 16-19 had varying amounts of $N$ and $P$ applied at the time of seeding. Generally, these were high applications of $\mathrm{N}$ with low and high applications of $P$ (Treatments 16 and 18 , respectively) 
Table 25. Three-year average biomass and cover for seeded grasses, forbs, and shrubs for the subsoil fertility plots. ${ }^{\dagger}$

\begin{tabular}{|c|c|c|c|c|c|c|c|c|}
\hline \multirow{2}{*}{$\begin{array}{l}\text { Fertilizer } \\
\text { Treatment } \\
\text { Number }\end{array}$} & \multicolumn{2}{|c|}{ Grasses } & \multicolumn{2}{|c|}{ Forbs } & \multicolumn{2}{|c|}{ Shrubs } & \multicolumn{2}{|c|}{ Total } \\
\hline & $\begin{array}{c}\text { Biomass } \\
(\mathrm{kg} / \mathrm{ha})\end{array}$ & $\begin{array}{l}\text { Cover } \\
(\%)\end{array}$ & $\begin{array}{l}\text { 8iomass } \\
(\mathrm{kg} / \mathrm{ha})\end{array}$ & $\begin{array}{c}\text { Cover } \\
(\%)\end{array}$ & $\begin{array}{l}\text { Biomass } \\
(\mathrm{kg} / \mathrm{ha})\end{array}$ & $\begin{array}{l}\text { Cover } \\
(\%)\end{array}$ & $\begin{array}{l}\text { Biomass } \\
(\mathrm{kg} / \mathrm{ha})\end{array}$ & $\begin{array}{l}\text { Cover } \\
(\%)\end{array}$ \\
\hline 1 & $3564^{\mathrm{a}}$ & $17.6^{\mathrm{ab}}$ & $26^{1}$ & $1.2^{\mathrm{abc}}$ & $1775^{\text {def }}$ & $10.8^{\text {bcdef }}$ & 5365 & 29.6 \\
\hline 2 & $2740^{b}$ & $18.3^{\mathrm{a}}$ & $320^{d}$ & $0.7^{\mathrm{abc}}$ & $555^{\mathrm{hi}}$ & $3.0^{f}$ & 3615 & 22.0 \\
\hline 3 & $1431^{\mathrm{hi}}$ & $12.8^{a b c}$ & $150^{h}$ & $0.4^{a b c}$ & $1462^{e f g}$ & $11.8^{\mathrm{abcdef}}$ & 3443 & 25.0 \\
\hline 4 & $1439^{h i}$ & $12.6^{a b c}$ & $340^{c}$ & $2.2^{\mathrm{ab}}$ & $1304^{\mathrm{fgh}}$ & $9.9^{\text {cdef }}$ & 3083 & 24.7 \\
\hline 5 & $1847^{\text {efghi }}$ & $13.1^{a b c}$ & $270^{\mathrm{e}}$ & $2.0^{\mathrm{abc}}$ & $2412^{b c d}$ & $14.0^{\mathrm{abcd}}$ & 4529 & 29.1 \\
\hline 6 & $2057^{\text {def }}$ & $13.8^{a b c}$ & $240^{f}$ & $0.3^{\mathrm{b}}$ & $2337^{\mathrm{cd}}$ & $14.1^{\mathrm{abcd}}$ & 4634 & 28.2 \\
\hline 7 & $2711^{b c}$ & $12.7^{\mathrm{a} b c}$ & $120^{i}$ & $0.9^{\mathrm{abc}}$ & $973^{g h}$ & $6.9^{\mathrm{def}}$ & 3804 & 20.5 \\
\hline 8 & $2411^{b c d}$ & $8.9^{\mathrm{abc}}$ & $380^{b}$ & $1.5^{\mathrm{abc}}$ & $13^{i}$ & $0.8^{9}$ & 2804 & 11.2 \\
\hline 9 & $1510^{g h i}$ & $9.8^{a b c}$ & $210^{9}$ & $1.5^{\mathrm{abc}}$ & $3265^{a}$ & $19.9^{\mathrm{a}}$ & 4385 & 31.2 \\
\hline 10 & $1954^{\text {defg }}$ & $8.8^{\mathrm{abc}}$ & $50^{k}$ & $0.4^{a b c}$ & $2382^{c d}$ & $12.0^{\mathrm{abcde}}$ & 4386 & 21.2 \\
\hline 11 & $1392^{h i}$ & $8.6^{\mathrm{bc}}$ & $70^{j}$ & $0.6^{\mathrm{abc}}$ & $2207^{\text {cde }}$ & $11.1^{\text {abcdef }}$ & 3669 & 20.3 \\
\hline 12 & $1383^{h i}$. & $9.4^{\mathrm{abc}}$ & $70^{j}$ & $0.4^{a b c}$ & $1155^{\mathrm{fgh}}$ & $5.9^{\mathrm{def}}$ & 2608 & 15.7 \\
\hline 13 & $1763^{f g h}$ & $.15 .5^{\mathrm{abc}}$ & $200^{9}$ & $1.2^{\mathrm{abc}}$ & $1438^{\text {efg }}$ & $7.2^{\text {def }}$ & 3401 & 23.9 \\
\hline 14 & $2839^{b}$ & $18.3^{\mathrm{a}}$ & $50^{k}$ & $0.2^{c}$ & $2830^{a b c}$ & $13.6^{\mathrm{abcd}}$ & 5719 & 32.1 \\
\hline 15 & $2255^{\text {cde }}$ & $18.2^{\mathrm{a}}$ & $270^{\mathrm{e}}$ & $2.0^{a b c}$ & $887^{\text {gh }}$ & $4.4^{\mathrm{ef}}$ & 3412 & 24.6 \\
\hline 16 & $2098^{\text {def }}$ & $7.7^{\mathrm{a}}$ & $670^{a}$ & $2.3^{\mathrm{a}}$ & $2167^{\text {cde }}$ & $14.5^{\mathrm{abcd}}$ & 4335 & 24.5 \\
\hline 17 & $1248^{i}$ & $6.7^{c}$ & $260^{\mathrm{e}}$ & $2.0^{a b c}$ & $1306^{\mathrm{fgh}}$ & $6.9^{\mathrm{def}}$ & 2815 & 15.6 \\
\hline 18 & $1622^{f g h i}$ & $12.4^{\mathrm{abc}}$ & $380^{b}$ & $1.8^{\mathrm{abc}}$ & $3202^{\mathrm{ab}}$ & $19.9^{\mathrm{ab}}$ & 5204 & 34.1 \\
\hline 19 & $1849^{\mathrm{cdf} g h i}$ & $7.8^{c}$ & $330^{\mathrm{cd}}$ & $1.8^{a b c}$ & $2820^{a b c}$ & $14.5^{\mathrm{abcd}}$ & 4333 & 24.1 \\
\hline 20 & $1251^{i}$ & $10.7^{a b c}$ & $320^{d}$ & $2.0^{\mathrm{abc}}$ & $1915^{\text {def }}$ & $16.4^{\mathrm{abc}}$ & 3486 & 29.1 \\
\hline
\end{tabular}

tMeans within columns followed by the same letter are not statistically significant at the .05 level.

and low applications of $\mathrm{N}$ with high and low applications of $P$ (Treatments 17 and 19, respectively). The high $N$ rates (Treatments 16 and 18) produced greater grass, forb, and shrub biomass compared to Treatments 17 and 19 and control plots.

Low rates of $N$ with low rates of $P$ (Treatment 19) also produced greater grass and shrub biomass (Table 25). However, low $N$ rates and high $P$ rates (Treatment 17) generally lowered all biomass and cover measurements. Pretreatment soil tests indicated that $P$ was deficient. However, these data indicate that the addition of $P$ does not contribute to plant establishment and growth. Therefore other factors must be limiting revegetation success.

\section{Soil Data for Topsoil Plots}

The soil in the topsoil over retorted shale fertility study was sampled at both the $0-30 \mathrm{~cm}$ depth (surface depth) and at the $30-60 \mathrm{~cm}$ depth (second depth), down to the retorted shale-soil interface. The 1980 fertility parameters from the two soil depths are reported in Table 26.

The electrical conductivity in the first depth was significantly different in Treatment $4(448 \mathrm{~kg}$ $\mathrm{N} /$ ha applied annually) compared to the control and all other treatments (Table 26). This treatment resulted in an electrical conductivity of $1.0 \mathrm{mmhos} / \mathrm{cm}$ which was not high enough to be detrimental to most plants. Significantiy higher electrical conductivity levels were measured in most of the second depth samples when compared with the electrical conductivity levels in the surface depth with the exception of Treatments 4 and 15. Second depth electrical conductivity levels may be the result of the downward movement of soil water containing soluble salts out of the surface depth or a result of the upward movement of soil water from underlying retorted shale. The source of the soluble salts needs to be investigated further. A]so, there was a slight decrease $(<1.0 \mathrm{mmhos} / \mathrm{cm})$ 
Table 26. The 1980 topsoil over retorted shale soil fertility parameters as influenced by treatments and depth.t

\begin{tabular}{|c|c|c|c|c|c|c|c|c|c|c|c|c|c|c|c|c|}
\hline \multirow{2}{*}{$\begin{array}{l}\text { Fertilizer } \\
\text { Treatment } \\
\text { Number }\end{array}$} & \multicolumn{3}{|c|}{ EC (mmhos $\left.\mathrm{cm}^{-1}\right)$} & \multicolumn{3}{|c|}{ pH } & \multicolumn{3}{|c|}{$\mathrm{NO}_{3}^{-}-\mathrm{N}(\mathrm{ppm})$} & \multicolumn{3}{|c|}{$\mathrm{NH}_{4}^{+}-\mathrm{N}(\mathrm{ppm})$} & \multicolumn{3}{|c|}{$P(\mathrm{ppm})$} & \multirow{2}{*}{$\frac{N(x)}{\operatorname{Depth} \mid}$} \\
\hline & Depth 1 & Depth 2 & Mean & Depth 1 & Depth 2 & Mean & Depth 1 & Depth 2 & Mean & Depth 1 & Depth 2 & Mean & Depth 1 & Depth 2 & Mean & \\
\hline $\begin{array}{l}1 \\
2 \\
3 \\
4\end{array}$ & $\begin{array}{l}0.60 \\
0.53 \\
0.67 \\
1.03\end{array}$ & $\begin{array}{l}1.03 \\
0.80 \\
0.70 \\
0.97\end{array}$ & $\begin{array}{l}0.82 \\
0.67 \\
0.68 \\
1.00\end{array}$ & $\begin{array}{l}8.03 \\
8.00 \\
7.97 \\
7.77\end{array}$ & $\begin{array}{l}8.03 \\
8.03 \\
8.17 \\
7.93\end{array}$ & $\begin{array}{l}8.03 \\
8.02 \\
8.07 \\
7.85\end{array}$ & $\begin{array}{r}0.45 \\
6.94 \\
6.16 \\
38.79\end{array}$ & $\begin{array}{r}0.91 \\
2.39 \\
4.55 \\
14.00\end{array}$ & $\begin{array}{r}0.68 \\
4.67 \\
5.36 \\
26.40\end{array}$ & $\begin{array}{l}1.63 \\
3.03 \\
5.70 \\
4.57\end{array}$ & $\begin{array}{l}1.60 \\
2.73 \\
4.33 \\
5.03\end{array}$ & $\begin{array}{l}1.62 \\
2.88 \\
5.02 \\
4.80\end{array}$ & $\begin{array}{l}24.73 \\
17.27 \\
25.10 \\
26.13\end{array}$ & $\begin{array}{l}11.10 \\
12.03 \\
13.07 \\
16.07\end{array}$ & $\begin{array}{l}17.92 \\
14.65 \\
19.08 \\
21.10\end{array}$ & $\begin{array}{l}0.062 \\
0.063 \\
0.063 \\
0.058\end{array}$ \\
\hline $\begin{array}{l}5 \\
6 \\
7 \\
8\end{array}$ & $\begin{array}{l}0.57 \\
0.50 \\
0.50 \\
0.57\end{array}$ & $\begin{array}{l}0.63 \\
0.70 \\
0.73 \\
0.67\end{array}$ & $\begin{array}{l}0.60 \\
0.60 \\
0.62 \\
0.62\end{array}$ & $\begin{array}{l}7.93 \\
8.07 \\
8.03 \\
8.00\end{array}$ & $\begin{array}{l}7.97 \\
8.07 \\
8.20 \\
8.07\end{array}$ & $\begin{array}{l}7.95 \\
8.07 \\
8.12 \\
8.03\end{array}$ & $\begin{array}{l}2.22 \\
0.46 \\
0.91 \\
0.27\end{array}$ & $\begin{array}{l}0.86 \\
0.24 \\
1.67 \\
0.60\end{array}$ & $\begin{array}{l}1.54 \\
0.35 \\
1.29 \\
0.43\end{array}$ & $\begin{array}{l}2.73 \\
1.37 \\
3.40 \\
3.00\end{array}$ & $\begin{array}{l}2.27 \\
3.43 \\
2.97 \\
2.07\end{array}$ & $\begin{array}{l}2.50 \\
2.40 \\
3.18 \\
2.53\end{array}$ & $\begin{array}{l}24.23 \\
24.43 \\
24.83 \\
20.47\end{array}$ & $\begin{array}{r}10.40 \\
10.87 \\
15.90 \\
9.97\end{array}$ & $\begin{array}{l}17.32 \\
17.65 \\
20.37 \\
15.22\end{array}$ & $\begin{array}{l}0.066 \\
0.060 \\
0.059 \\
0.064\end{array}$ \\
\hline $\begin{array}{r}9 \\
10 \\
11 \\
12\end{array}$ & $\begin{array}{l}0.53 \\
0.53 \\
0.67 \\
0.50\end{array}$ & $\begin{array}{l}0.83 \\
0.73 \\
0.77 \\
0.67\end{array}$ & $\begin{array}{l}0.68 \\
0.63 \\
0.72 \\
0.58\end{array}$ & $\begin{array}{l}7.97 \\
8.00 \\
7.90 \\
7.87\end{array}$ & $\begin{array}{l}8.03 \\
8.07 \\
8.03 \\
7.97\end{array}$ & $\begin{array}{l}8.00 \\
8.03 \\
7.97 \\
7.92\end{array}$ & $\begin{array}{l}2.73 \\
3.08 \\
3.08 \\
1.38\end{array}$ & $\begin{array}{l}6.06 \\
3.80 \\
8.31 \\
1.22\end{array}$ & $\begin{array}{l}4.40 \\
3.44 \\
5.69 \\
1.30\end{array}$ & $\begin{array}{l}0.47 \\
1.67 \\
2.03 \\
3.67\end{array}$ & $\begin{array}{l}1.17 \\
4.10 \\
4.57 \\
2.50\end{array}$ & $\begin{array}{l}0.82 \\
2.88 \\
3.30 \\
3.08\end{array}$ & $\begin{array}{l}24.33 \\
22.73 \\
21.33 \\
17.07\end{array}$ & $\begin{array}{r}9.33 \\
7.97 \\
13.70 \\
9.77\end{array}$ & $\begin{array}{l}16.83 \\
15.35 \\
17.52 \\
13.42\end{array}$ & $\begin{array}{l}0.060 \\
0.064 \\
0.064 \\
0.066\end{array}$ \\
\hline $\begin{array}{l}13 \\
14 \\
15\end{array}$ & $\begin{array}{l}0.43 \\
0.63 \\
0.70\end{array}$ & $\begin{array}{l}0.67 \\
0.80 \\
0.7 .0\end{array}$ & $\begin{array}{l}0.55 \\
0.72 \\
0.70\end{array}$ & $\begin{array}{l}7.97 \\
7.70 \\
7.73\end{array}$ & $\begin{array}{l}8.00 \\
7.87 \\
7.90\end{array}$ & $\begin{array}{l}7.98 \\
7.78 \\
7.82\end{array}$ & $\begin{array}{l}4.55 \\
0.00 \\
2.28\end{array}$ & $\begin{array}{l}2.49 \\
1.47 \\
3.26\end{array}$ & $\begin{array}{l}3.52 \\
0.73 \\
2.77\end{array}$ & $\begin{array}{l}1.40 \\
5.03 \\
6.30\end{array}$ & $\begin{array}{l}2.73 \\
3.60 \\
3.40\end{array}$ & $\begin{array}{l}2.07 \\
4.32 \\
4.85\end{array}$ & $\begin{array}{l}28.70 \\
40.43 \\
46.77\end{array}$ & $\begin{array}{l}14.50 \\
31.97 \\
38.17\end{array}$ & $\begin{array}{l}21.60 \\
36.20 \\
42.47\end{array}$ & $\begin{array}{l}0.079 \\
0.100 \\
0.120\end{array}$ \\
\hline 20 & 0.57 & 0.87 & 0.72 & 8.00 & 8.00 & 8.00 & 1.03 & 1.85 & 1.44 & 2.13 & 2.50 & $\dot{2} .32$ & 27.20 & 18.30 & 22.75 & 0.065 \\
\hline Mean & $0: 60$ & 0.76 & 0.68 & 7.96 & 8.03 & 7.99 & 4.19 & 3.12 & 3.66 & 3.01 & 2.78 & 2.90 & 24.93 & 14.39 & 19.66 & 0.068 \\
\hline \multicolumn{4}{|c|}{$\begin{array}{ll}\text { Tukey's } Q(p=.05) & \\
\text { Fertilizer } & \text { not significant } \\
\text { Oepth } & 0.044 \\
\text { Fert } \times \text { Depth 1 } & \text { not significant } \\
\text { Fert } x \text { Depth 2 } & \text { not significant }\end{array}$} & & $\begin{array}{l}0.29 \\
0.03 \\
0.04 \\
0.04\end{array}$ & . & & $\begin{array}{l}5.70 \\
0.89 \\
1.43 \\
1.43\end{array}$ & $\cdot$ & $\begin{array}{l}\text { not } \\
\text { not } \\
\text { not } \\
\text { not }\end{array}$ & $\begin{array}{l}\text { significa } \\
\text { significa } \\
\text { significa } \\
\text { significa }\end{array}$ & & $\begin{array}{l}\text { not } \\
\text { not }\end{array}$ & $\begin{array}{r}9.85 \\
1.34 \\
\text { significa } \\
\text { significa }\end{array}$ & & \\
\hline
\end{tabular}

tSee Table 23 for key to treatments.

in electrical conductivity in the surface depth from 1978 to 1979 . From 1979 to 1980 electrical conductivity at this depth increased slightly $(<0.5 \mathrm{mmhos} / \mathrm{cm})$.. Overall, this resulted in a decrease in electrical conductivity over time. Salts appear to be moving to lower depths over time since the electrical conductivity of the lower depth was generally higher in 1980 than in preceeding years.

The $\mathrm{pH}$ measured in the surface depth al so showed several trends in 1980. The two highest rates of sewage sludge (Treatments 14 and 15 ) caused significantly lower $\mathrm{pH}$ values than all other treatments except the low phosphorus and low nitrogen treatment (Treatment 16) which had a higher $\mathrm{pH}$ than all the other treatments.

In the second depth $(30-60 \mathrm{~cm}$ below soil surface) of soil, pH was significantly higher in most treatments than $\mathrm{pH}$ values in the surface depth. These higher $\mathrm{pH}$ values may be related to the higher electrical conductivities measured in the second depth of soil.

Ammonium-nitrogen was not affected by fertility treatment or depth in 1980 . Nitrate-nitrogen was significantly higher in the highest annual nitrogen treatment (Treatment 4 ) than in all other treatments. It decreased sijghtiy in most treatments with depth, with the exception of the high nitrogen plus wood wastes treatments (Treatments 9-12). These treatments showed a slight increase in $\mathrm{N}_{3}^{-}-\mathrm{N}$ in the second soil depth.

Total nitrogen in the surface depth was higher in the two high sewage sludge with wood waste treatments (Treatments 14 and 15) than in any other treatments (Table 26). This was a result of the large amount of stabie organic nitrogen that was added in the sewage sludge. Little of the nitrogen had mineralized to inorganic nitrogen making it available for plant uptake by 1980 .

The total nitrogen in the surface depth increased slightly from $0.07 \%$ in 1978 to $0.09 \%$ in 1979 and then decreased to $0.03 \%$ in 1980. This significant decrease over time may be the result of the mineralization of organic nitrogen to plantavailable mineral nitrogen which has been taken up by plants.

The extractable phosphorus in the highest sludge application plots was significantly higher than in any of the other plots. Phosphorus in the plots receiving the next lowest rate of sewage sludge was also elevated, but not significantly. In the topsoil study no increase in extractable phosphorus resulted from phosphorus applied at $192 \mathrm{~kg} P / \mathrm{ha}$ above the control level (130 kg P/ha). This indicated that in this soil the level of phosphorus solubility from triple superphosphate was limited.

Extractable phosphorus in the topsoil plots did not change significantly in any of the fertilizer treatments with time. Extractable phosphorus was significantly lower in the second depth of soil compared to the surface depth over all fertilizer treatments. This difference reflects the depth at which the phosphorus fertilizer (0-44-0, triple superphosphate) was incorporated into the soil when it was applied. Phosphorus is quite immobile in the soil and therefore was not expected to move 
downward. This decreased level of phosphorus measured in the second soil depth should not adversely affect phosphorus availability to plants. A larger amount of the active plant roots are in the surface depth of soil where they are in contact with adequate levels of plant-available phosphorus.

The sets of fertilizer treatments applied to the topsoil plots, as well as time and soil depth, have influenced soil fertility parameters. In the annualiy applied $\mathrm{N}$ treatments only Treatment 4 significantly increased electrical conductivity over three years. The three-year average electrical conductivity measured in this treatment was 0.78 mhos $/ \mathrm{cm}$, which is not high enough to damage range plants.

In the annually applied nitrogen treatments $\mathrm{NO}_{3}^{-}-\mathrm{N}$ accumulated in the surface depth over time where $448 \mathrm{~kg} \mathrm{~N} / \mathrm{ha}$ was applied (Figure 58). Levels of $\mathrm{NH}_{4}^{+}-\mathrm{N}$ remained at relatively low levels in all of these treatments over three years. However, a significantly higher average level of $\mathrm{NH}_{4}^{+}-\mathrm{N}$ was measured in Treatments 3 and 4 than was measured in the control over three years. In 1980 the levels from all treatments and the control were less than $10 \mathrm{ppm}$.

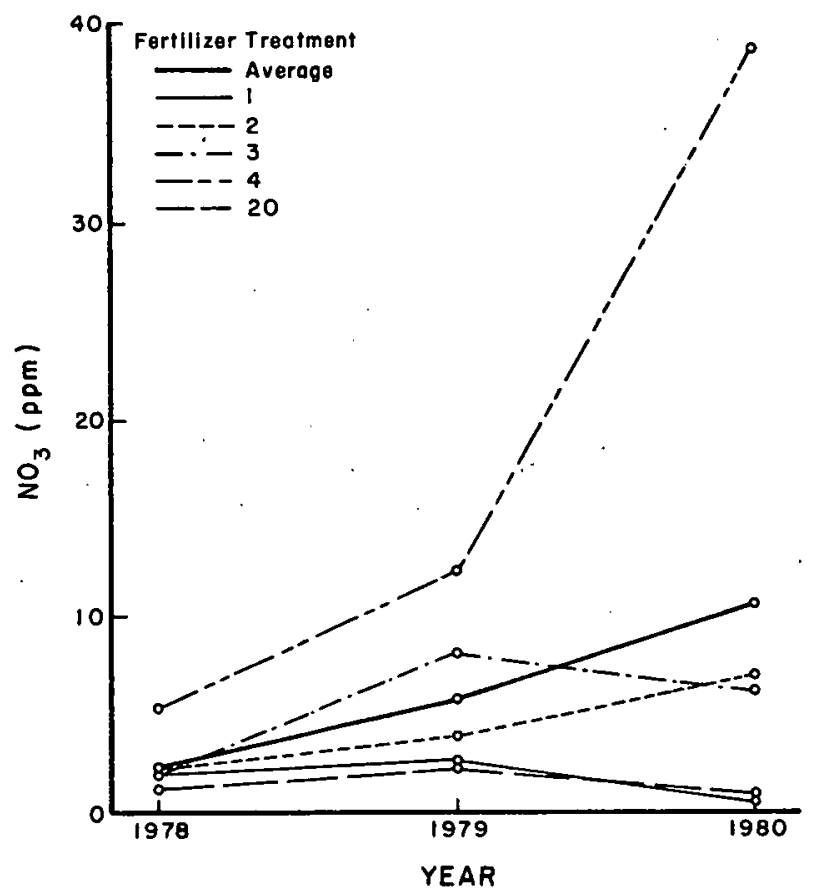

Figure 58. Effect over time of annually applied $N$ in the topsoil over retorted shale study on $\mathrm{NO}_{3}^{-}-\mathrm{N}$ in the surface depth $(0-30 \mathrm{~cm})$ of soil.

The residual nitrogen treatments with and without wood wastes (Treatments 5-8 and 9-12) showed a significant decrease in $\mathrm{NO}_{3}^{-}-\mathrm{N}$ over time (Figure 59 ). There did not appear to be any effect from added wood wastes. The highest rate of nitrogen
(Treatments 8 and 12) increased $\mathrm{NO}_{3}^{-}-\mathrm{N}$ levels most during the year following application in 1978. By 1980 there were no differences between any of the treatments and the control in $\mathrm{NO}_{3}^{-}-\mathrm{N}$, indicating that there was no more $\mathrm{NO}_{3}^{-}-\mathrm{N}$ available for plant uptake than in the control. Much of the nitrogen added in these treatments apparently was lost from the system.

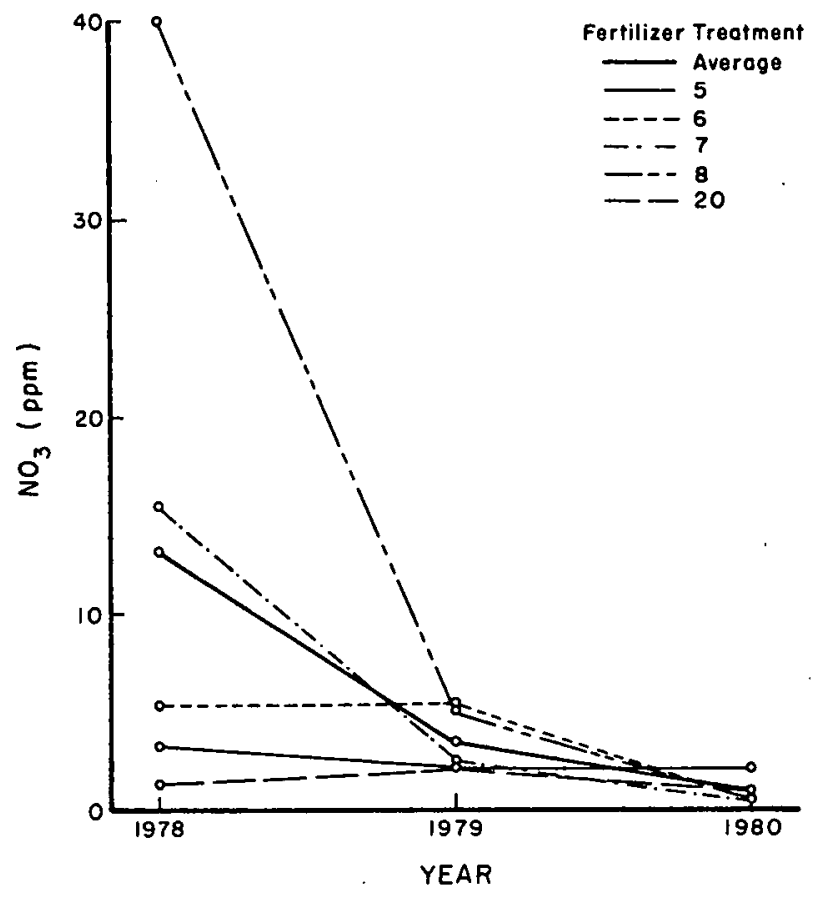

Figure 59. Effect of residual $\mathrm{N}$ over time on $\mathrm{NO}_{3}^{-}-\mathrm{N}$ in the $0-30 \mathrm{~cm}$ depth in the topsoil over retorted shale study.

Ammonium-nitrogen showed trends similar to $\mathrm{NO}_{3}^{-}-\mathrm{N}$ in these treatments. Wood wastes al so had no effect upon the level of $\mathrm{NH}_{4}^{+}-\mathrm{N}$ measured in the soil. This form of nitrogen decreased over time, and in 1980 no difference was seen between any of the treatments and the control. However, in $1978 \mathrm{NH}_{4}^{+}-\mathrm{N}$ was significantly higher compared to the control where the highest rates of nitrogen were added.

The highest rate of initially applied nitrogen both with and without wood wastes (Treatments 8 and 12) showed a significant decrease in available phosphorus which was more pronounced where wood wastes were added (Table 26). This may indicate that some immobilization of phosphorus was occurring in these treatments due to the presence of the wood wastes.

A significantly higher electrical conductivity was measured where the highest rate of nitrogen with wood wastes (Treatment 12) was added. This significance from a three-year average resulted mainly from the high electrical conductivity level in this treatment in 1978. By 1980 there was no difference in electrical conductivity in any of the high nitrogen treatment plots. 
The additions of sewage sludge significantly affected the levels of electrical conductivity, $\mathrm{NO}_{3}^{-}-\mathrm{N}$, total nitrogen, and extractable phosphorus in the surface depth of soil over time.

The two highest sewage siudge rates (Treatments 14 and 15) resulted in significantly higher electrical conductivity levels over three years than were measured in the control, but the levels were not detrimental to plant growth. However, in 1980 none of these electrical conductivity levels was different from the control (Table 26).

Nitrate-nitrogen decreased over time in all the plots treated with sewage sludge. However, average $\mathrm{NO}_{3}^{-}-\mathrm{N}$ measured in the plots treated with siudge (Treatment 13) was higher than the control treatment. The two highest rates of sludge applied with wood wastes maintained significantly higher total nitrogen levels for all three years than were measured in the control plot.

The sewage sludge treatments significantly increased the level of extractable phosphorus in the soil over the control. Figure 60 shows the level of phosphorus measured in plots receiving sludge (Treatments 13-15), $192 \mathrm{~kg}$ P/ha (Treatments 17. and 18), $130 \mathrm{~kg}$ P.ha (Treatment 20), and $56 \mathrm{~kg} \mathrm{P} / \mathrm{ha}$ (Treatments 16 and 19). The two highest levels of phosphorus measured in the soil resulted from the two highest rates of sludge (Treatments 14 and 15). Sewage sludge was a good source of phosphorus because it resulted in higher levels of phosphorus in the soil than were measured in piots receiving $192 \mathrm{~kg} \mathrm{P} / \mathrm{ha}$ as triple superphosphate.

The fertility parameters influenced significantiy by applying two rates of nitrogen and phosphorus (Treatments 16-19) were $\mathrm{pH}, \mathrm{NH} \frac{\mathrm{t}}{4}-\mathrm{N}$, and extractable phosphorus. Soil $\mathrm{pH}$ was higher over three years in the low nitrogen and low phosphorus treatments than in the control in 1978. However, by 1980 the $\mathrm{pH}$ levels measured in this set of treatment plots showed no significant differences (Table 26).

Extractable-phosphorus in Treatments 16 and 17 was significantly lower than the control over three years. High levels of phosphorus (192 kg P/ha) did not result in higher levels of extractable phosphorus in the topsoil than were found when $130 \mathrm{~kg}$ $\mathrm{P} /$ ha is applied (Figure 60).

\section{Vegetation Data for Topsoil Plots}

Topsoil parameters explain only $14 \%$ to $30 \%$ of the variation of biomass and cover of vegetation for 1980. Available $N$ and $P$ are at similar levels when comparing all treatments after three years (Table 26). However, biomass and cover of vegetation were significantly different between treatments (Table 27).

Biomass and percent cover of total vegetation and grasses in Treatments 1 . and 2 (56 and $112 \mathrm{~kg}$ N/ha applied annually) increased over the control (Table 27). However, higher $\mathrm{N}$ levels, 224 and $448 \mathrm{~kg} \mathrm{~N} / \mathrm{ha}$ (Treatments 3 and 4 ), produced less grass and total vegetative biomass and cover than the control (Treatment 20).

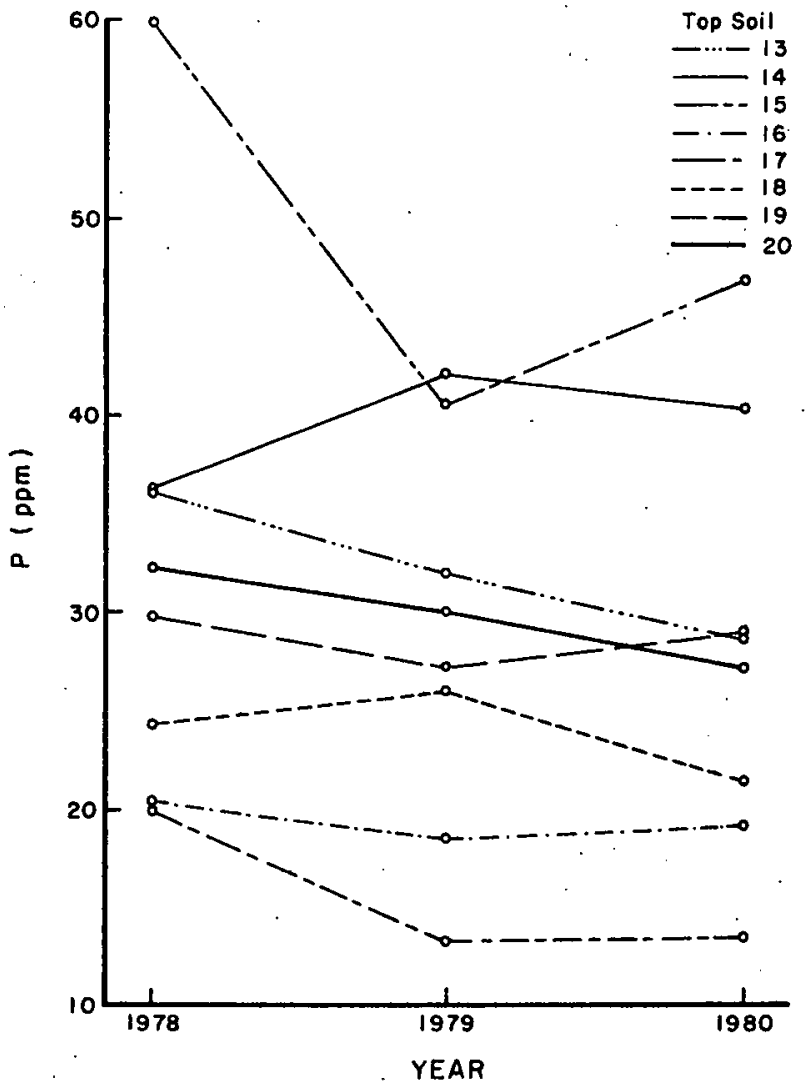

Figure 60. Effect of selected fertilizer treatments on extractable $P$ in the upper $30 \mathrm{~cm}$ of the topsoil over retorted shale study.

Total vegetation and grass biomass and cover in 1980 after an initial application of 224,448 , and $896 \mathrm{~kg} \mathrm{~N} / \mathrm{ha}$ in 1977 (Treatments 5-7) all showed an increase compared to the control (Table 27). The highest application, $1792 \mathrm{~kg} \mathrm{~N} / \mathrm{ha}$ in a single application (Treatment 8), produced less total vegetative biomass and cover than the control and the lower fertilizer applications (Treatments 1-7). The highest level of fertilizer (Treatment 8 ) burned the foliage of the new seedlings and resulted in poorer plant establ ishment compared to the lower rates of nitrogen application. Shrub biomass and cover in Treatments 5-8 were lower compared to the control. Increased competition from grasses in these treatments may have reduced the vigor or density of shrubs.

Application of $\mathrm{N}$ plus wood wastes (Treatments 9-12) reduced total biomass except in Treatment 9 which had similar biomass to the control (Table 27). Treatments 9 and 10 had lower grass biomass compared to the control, and Treatments 11 and 12 had similar grass biomass production compared to the control. Forb biomass and cover in Treatments 9 and 10 were greater compared to Treatments 11 and 12. This may have been due to lessened grass competition in Treatments 9 and 10 .

Biomass of total vegetation and grasses was lower in the $\mathrm{N}$ plus wood wastes treatments (Treatments 9-12) compared to the single applications of 
Table 27. Average biomass and cover for seeded grasses, forbs, and shrubs for the topsoil fertility plots.t Data was for 1980, three years after study was initiated.

\begin{tabular}{|c|c|c|c|c|c|c|c|c|}
\hline \multirow{2}{*}{$\begin{array}{c}\text { Fertilizer } \\
\text { Trea tment } \\
\text { Number }\end{array}$} & \multicolumn{2}{|c|}{ Grasses } & \multicolumn{2}{|c|}{ Forbs } & \multicolumn{2}{|c|}{ Shrubs } & \multicolumn{2}{|c|}{ Total } \\
\hline & $\begin{array}{l}\text { Biomass } \\
(\mathrm{kg} / \mathrm{ha})\end{array}$ & $\begin{array}{l}\text { Cover } \\
(\%)\end{array}$ & $\begin{array}{l}\text { Biomass } \\
(\mathrm{kg} / \mathrm{ha})\end{array}$ & $\begin{array}{c}\text { Cover } \\
(\%)\end{array}$ & $\begin{array}{c}\text { Biomass } \\
(\mathrm{kg} / \mathrm{ha})\end{array}$ & $\begin{array}{l}\text { Cover } \\
(\%)\end{array}$ & $\begin{array}{c}\text { Biomass } \\
(\mathrm{kg} / \mathrm{ha})\end{array}$ & $\begin{array}{l}\text { Cover } \\
(\%)\end{array}$ \\
\hline 1 & $2395^{c d}$ & $18^{\mathrm{de}}$ & $560^{\text {cdefg }}$ & $2.7^{\mathrm{bcd}}$ & $275^{\text {cdefg }}$ & $2.2^{\text {cde }}$ & 3230 & 22.9 \\
\hline 2 & $4028^{b}$ & $26^{\mathrm{b}}$ & $691^{\mathrm{cd}}$ & $4.0^{b}$ & $267^{\text {defgh }}$ & $2.6^{\mathrm{cd}}$ & 4986 & 32.6 \\
\hline 3 & $1750^{\text {efg }}$ & $12^{\text {fghij }}$ & $566^{\text {cdefg }}$ & $3.4^{\mathrm{bc}}$ & $25^{i j}$ & $0.3^{g h}$ & 2341 & 13.7 \\
\hline 4 & $1909^{\text {ef }}$ & $14^{e f g h}$ & $306^{g h}$ & $1.4^{\mathrm{de}}$ & $329^{\text {cdef }}$ & $2.9^{c}$ & 2544 & 18.5 \\
\hline 5 & $2436^{c d}$ & $20^{\mathrm{cd}}$ & $584^{c d e f}$ & $2.6^{\mathrm{bcd}}$ & $369^{\text {cdef }}$ & $2.9^{c}$ & 3389 & 25.5 \\
\hline 6 & $2599^{C}$ & $13^{f g h i}$ & $1555^{\mathrm{a}}$ & $6.2^{\mathrm{a}}$ & $111^{\text {ghij }}$ & $0.9^{f g h}$ & 4265 & 20.1 \\
\hline 7 & $2651^{c}$ & $15^{\mathrm{efg}}$ & $421^{\text {efgh }}$ & $2.7^{\mathrm{bcd}}$ & $253^{\text {efgh }}$ & $2.0^{\text {cdef }}$ & 3325 & 19.7 \\
\hline 8 & $1921^{\text {ef }}$ & $1^{g h i j}$ & $210^{h}$ & $0.9^{c}$ & $84^{h i j}$ & $0.9^{f g h}$ & 2215 & 12.8 \\
\hline 9 & $1572^{f g}$ & $9^{i j}$ & $684^{c d}$ & $3.4^{b c}$ & $915^{\mathrm{a}}$ & $6.6^{\mathrm{a}}$ & 3171 & 19.0 \\
\hline 10 & $1422^{g}$ & $10^{\mathrm{hij}}$ & $594^{\mathrm{cde}}$ & $4.0^{b}$ & $313^{\text {cdef }}$ & $2.1^{\text {cde }}$ & 2329 & 16.1 \\
\hline 11 & $2065^{\mathrm{de}}$ & $14^{\text {efgh }}$ & $487^{\text {cdefg }}$ & $3.1^{b c}$ & $182^{f i j}$ & $1.3^{\mathrm{efg}}$ & 2734 & 18.4 \\
\hline 12 & $1867^{\text {efg }}$ & $13^{\mathrm{fghi}}$ & $325^{f g h}$ & $1.9^{\text {cde }}$ & $462^{c}$ & $2.4^{\mathrm{cde}}$ & 2654 & 17.3 \\
\hline 13 & $6416^{\mathrm{a}}$ & $13^{\text {fghij }}$ & $494^{\text {cdefg }}$ & $3.1^{\mathrm{bc}}$ & $307^{\text {cdefg }}$ & $2.1^{\text {cdef }}$ & 7217 & 18.2 \\
\hline 14 & $4385^{b}$ & $34^{\mathrm{a}}$ & $433^{\text {defgh }}$ & $1.7^{\mathrm{cde}}$ & $119^{g h i j}$ & $1.2^{\text {defgh }}$ & 4937 & 36.9 \\
\hline 15 & $2508^{c d}$ & $24^{b c}$ & $419^{\text {efgh }}$ & $2.1^{\mathrm{cde}}$ & $15^{j}$ & $<0.1^{\mathrm{h}}$ & 2942 & 26.1 \\
\hline 16 & $1871^{\text {efg }}$ & $13^{f g h i j}$ & $711^{c}$ & $4.1^{b}$ & $427^{\text {cde }}$ & $2.4^{\mathrm{cde}}$ & 3009 & 19.5 \\
\hline 17 & $1929^{\text {ef }}$. & $16^{\text {def }}$ & $467^{\text {cedfgh }}$ & $3.1^{b c}$ & $347^{\text {cdef }}$ & $2.1^{\mathrm{cdef}}$ & 2737 & 21.2 \\
\hline 18 & $1925^{\mathrm{ef}}$ & $1^{g h i j}$ & $945^{b}$ & $4.1^{b}$ & $225^{f i j}$ & $1.4^{\text {defg }}$ & 3095 & 16.5 \\
\hline 19 & $2062^{\mathrm{de}}$ & $17^{\text {def }}$ & $422^{\mathrm{efgh}}$ & $1.8^{\mathrm{cde}}$ & $314^{\text {cdef }}$ & $2.4^{\mathrm{cde}}$ & 2798 & 21.2 \\
\hline 20 & $1876^{e f}$ & $10^{h i j}$ & $599^{\mathrm{cde}}$ & $3.4^{b c}$ & $664^{b}$ & $4.1^{b}$ & 3139 & 17.5 \\
\hline
\end{tabular}

tMeans within columns followed by the same letter are not statistically significant at the .05 level.

N (Treatments 5-8) in 1980 (Table 27) except for Treatment 12 compared to Treatment 8 .

Sewage sludge applications (Treatments 13-15) produced more grass biomass and cover, similar forb biomass and cover, and significantly less shrub biomass and cover compared to the control (Treatment 20)(Table 27). However, only the lower sewage sludge applications (Treatments 13 and 14) produced greater total biomass compared to the control.

Treatment 13 had approximately the same quantity of $N /$ ha as Treatment 5 which were both applied in a single application at the time of planting (Table 27). Three years later in 1980 , the sewage sludge alone (Treatment 13) produced more than twice the biomass and herbage cover as an equivalent amount of nitrogen as $\mathrm{NH}_{4} \mathrm{NO}_{3}$ fertilizer (Treatment 5). Thus, the sewage sludge does indeed contribute more as a soil amendment than commercial nitrogen.

It is possible to compare Treatments 14 and 15 where wood waste was added along with sewage sludge with Treatments 10 and 11 where wood waste was added to an equivalent amount of commercial nitrogen at the time of seeding. Again, it is noted that the sewage sludge along with the wood waste produced significantly more biomass and cover than the commercial $\mathrm{NH}_{4} \mathrm{NO}_{3}$ along with wood waste. The differences were substantially more for the lighter applications of nitrogen ( $448 \mathrm{~kg} \mathrm{~N} / \mathrm{ha}$ ) than the heavier applications ( $896 \mathrm{~kg} \mathrm{~N} / \mathrm{ha})$.

Treatments 16-19 had varying quantities of nitrogen and phosphorus applied to the soil at the time of seeding. Treatments 16 and 18 had $896 \mathrm{~kg}$ $\mathrm{N} / \mathrm{ha}$ applied along with $56 \mathrm{~kg} \mathrm{P} / \mathrm{ha}$ and $192 \mathrm{~kg} \mathrm{P} / \mathrm{ha}$, respectively. Both of these treatments produced about the same biomass and herbage cover and were not significantly different from the control (Treatment 20). Treatments 17 and 19 had lower nitrogen than Treatments 16 and 18, but both had the same quantity of nitrogen $(112 \mathrm{~kg} \mathrm{~N} / \mathrm{ha})$. Each treatment (17 and 19) had different quantities of phosphorus, $192 \mathrm{~kg}$ and $56 \mathrm{~kg} \mathrm{P} / \mathrm{ha}$, respectively. Again, there were no significantly differences in biomass and cover between the two treatments. The 
biomass yield for Treatments 17 and 19 was significantly below the control, but percent ground cover was slightly higher than the control (Table 27).

It is of interest to compare Treatment 7 (where $896 \mathrm{~kg} \mathrm{~N} / \mathrm{ha}$ alone was applied at the time of seeding) to Treatment $16(896 \mathrm{~kg} \mathrm{~N} / \mathrm{ha}$ plus $56 \mathrm{~kg}$ $\mathrm{P} / \mathrm{ha})$ and Treatment $18(896 \mathrm{~kg} \mathrm{~N} / \mathrm{ha}$ plus $192 \mathrm{~kg}$ $\mathrm{P} / \mathrm{ha}$ ). Treatment 7 produced more total vegetation and grass biomass and cover than either Treatment 16 or 18 where phosphorus was added and only slightly more than the control (Treatment 20). However, Treatments 16 and 18 produced slightly less total biomass and cover than the control (Table 27). This indicates that the addition of phosphorus may not contribute to plant establishment even though the soil tests indicated that phosphorus was deficient.

\section{CONCLUSIONS}

After three years the soil parameters analyzed in both the fertility studies indicated that when low levels of nitrogen and phosphorus were added, there were no fertility problems associated with either the subsoil or topsoil material used to reestablish native range species. The other rates of nitrogen used in this study were too high to recommend because much of the nitrogen was lost from the soil and could not be used by plants or the small seedlings were actually burned by the excessive amounts. Plant growth did not account for the loss, nor were increased levels of nitrogen measured in the soil that would account for the amounts applied. The high nitrogen treatments also increased electrical conductivity levels in the topsoil plots during the first growing season which may have had detrimental effects upon germination and seedling survival.

The addition of sewage sludge at $224 \mathrm{MT} / \mathrm{ha}$ with wood wastes increased the level of available phosphorus in the soil above levels measured in the plots where $130 \mathrm{~kg} \mathrm{P} / \mathrm{ha}$ was applied. Sewage sludge may have had positive effects upon plant growth.by lowering $\mathrm{pH}$ over time and by supplying trace elements and organic matter. It is probably not economical to recommend the application of sewage sludge because of the high transportation costs involved if sludge was not available near the reclamation site.

In general, electrical conductivity had decreased in the top $30 \mathrm{~cm}$ of soil in both studies over three years: The elevated electrical conductivity levels measured in 1978 have decreased to levels not different from levels measured in the control.

Electrical conductivity levels in the second depth of topsoil over retorted shale increased significantly over time in all fertilizer treatments. The present electrical conductivity levels, however, are well below levels that would have detrimental effects on plant growth. These elevated subsurface electrical conductivity levels in the topsoil over retorted shale study should be monitored closely in the future. Subsequent years' data from this study should indicate whether the level of soluble salts are coming from the retorted shale below and, if so, will they increase to a level that would be harmful to plants. Also, saturated extracts from the subsurface soil should be analyzed to determine specifically which soluble salts are present to determine whether the subsurface salts could have moved down from the surface.

The following conclusions concerning vegetation are based on 1978 through 1980 data for the subsoil study and 1980 vegetation data for the topsoil study. Changes in these conclusions may occur as the vegetation develops in future years.

Generally in the subsoil plots, higher rates of $N$ (Treatments $3,4,7,8,11$, and 12) tended to inhibit total vegetation increases compared to control plots. Lower $\mathrm{N}$ levels (Treatments $1,2,5,6$, $9,10,13$, and 14) consistently provided greater total vegetation production compared to production in the control plots (Table 25). Therefore, low rates of $\mathrm{N}$ may be beneficial to plant establishment.

On the topsoil plots, low amounts of $N$ may be more beneficial than high amounts due to salt effects. Nitrogen, especially at higher rates, may not promote enough vegetation increase to justify its application. This is due in part to the adaptability of native species to the low levels of $\mathrm{N}$ present in native soils. It is concluded that higher levels of $p$ are of no consequence for increased vegetation growth. Continued sampling may more clearly illustrate the long-term fertility requirements.

\section{LITERATURE CITED}

Bremner, J. M. 1965. Inorganic forms of nitrogen. Pages 1179-1237 in C. A. Black, ed. Methods of soil analysis, Part 2. Am. Soc. Agron., Madison, Wis.

Corwin, M. K., B. R. Sabey, and W. A. Berg. 1980 Fertility requirements for estabi ishing native spectes on disturbed range soils. 72nd Annu. Meet., Am. Soc. Agron., Detroit, Mich.; 30 Nov5 Dec. (Abstr.)

Lindsay, W. L. 1979.. Chemical equilibria in soils. Wil ey-Interscience, New York.

Power, J.F. 1967. The effect of moisture on ferti]izer nitrogen immobilization in grasslands. Soil Sci. Soc. Am. Proc. 31:223-226.

Power, J. F. 1977. Nitrogen transformation in grassland ecosystem. Pages 195-205 in J. K. Marshall, ed. Proceedings, Symposium on Belowground Ecosystems. Colo. State Univ., Dep. Range Sci., Sci. Ser. 26.

Power, J. F. 1980. Response of semi-arid grassland sites to nitrogen fertilizer. II. Fertilizer recovery. Soil Sci. Soc. Am. J. 44: 550-555.

Power, J. F., and J. Alessi. 1971. Nitrogen fertilization of semiarid grasslands:' Plant growth and soil mineral $N$ levels. Agron. J. $63: 277-280$. 
Power, J. F., J. Alessi, G, A. Reichman, and D. L. Grunes. 1973. Recoyery, residual effects, and fate of nitrogen fertilizer sources in a semiarid region. Agron. J. 65:765-768.

Silviera, D. J., T. R. Garland, and R. E. Wildung. 1979. Lithium in leachates derived from retorted oil shale. 71 st Annu. Meet., Am. Soc; Agron., Ft. Collins, Colo., 5-10 Aug. (Abstr.)

Soltanpour, P. N., A. E. Ludwick, and J. 0. Reuss. 1979. Guide to fertilizer recommendations.

Colo. State Univ., Coop. Ext. Serv.

Technicon Industrial Systems. 1977. Individual/ simultaneous determination of total nitrogen and/or phosphorus in $\mathrm{BD}$ acid digests. Industrial Method No. 334-742/B+. Tarrytown, N.Y.

U.S. Sal inity Laboratory Staff. 1954. Diagnosis and improvement of saline and alkali soils U.S. Dep. Agric., Agric. Handbk. 60.

\section{AVAILABLE PUBLICATIONS AND/OR ABSTRACTS}

Corwin, M. K., B. R. Sabey, and W. A. Berg. 1980. Fertility requirements for establishing native species on disturbed range soils. 72nd Annu. Meet., Am. Soc. Agron., Detroit, Mich., 30 Nov5 Dec. (Abstr.) 


\title{
ECOGENETIC VARIABILITY IN NATIVE SHRUBS AND THE STRUCTURE OF NATURAL COMMUNITIES AS RELATED TO THE REESTABLISHMENT OF VEGETATION ON DISTURBED ARID SHRUBLANDS
}

\author{
Richard T. Ward, Ralph L. Dix, and William L. Slauson \\ Department of Botany and Plont Pathology \\ Colorado State University \\ Fort Collins, Colorado 80523
}

\section{ECOTYPIC STUDIES}

\section{Objectives}

1. Evaluate the natural variation within species (especially shrubs) native to the Piceance Basin.

2. Relate this variation to the environments which, through natural selection, produced it:

3. Make recommendations regarding source materials which can be expected to give long-term, natural success on particular sites.

\section{Methods}

Populations of nine native species (six shrub, two grass, and one forb) have been examined for ecotypic variation in a common garden at the Intensive Study Site. Methods of collection, propagation, measurement, and analysis are detailed in previous progress reports. In general, if populations which are phenotypically different in their natural environments retain their differences in a uniform environment (common garden), then the differences are genetically based. The variants are called ecotypes. Major results regarding ecotypic differentiation are given below.

\section{Results}

The four shrub species for which we have the most data are Cercocarpus montanus, purshia tridentata, Symphoricarpos oreophilus, Amelanchier utahensis, and Ceratoides lanata. Conclusions concerning them are presented first.

\section{Cercocarpus montaras}

Seedlings of Cercocarpus montanus were introduced to the common garden a year later than the other species, and only data for the 1980 growing season are available. Five populations, three from the Piceance Basin and two from the eastern slope of Colorado, show no significant differences in height measured throughout the season. Leaf size is also not significantly different; however, leaf shape expressed as the ratio of length to width is significantly different. These are the resuits of univariate analysis of variance.

A more sensitive test of the progression of height through the season is to fit the growth curves with polynomial equations and test for differences between the population's total growth curve. No significant differences were found. However, height averaged over the growing season is different $(F=3.7, p=.018)$. The populations al so differ on a measure of dormancy, the percent of leaves lost by October 29, 1980. Contingency table analys is of five populations versus percent of leaf loss in four equally spaced percentage classes $(0-25,26-50$, etc.) gives a chi square of 27.79 , which is significant below the $1 \%$ level. In general these populations display some, but not strong, differences.

\section{Purshia tridentata}

Purshia tridentata is represented in the common garden by four populations from the Piceance Basin. Evidence for ecotypic differentiation is present but not strong. One-way analysis of variance reveals interpopulation differences in stem length exists $(F=5.0, p=.01)$. Phenological development through four stages (vegetative growth, flower bud development, flowering, and fruiting) was measured on a corresponding scale of 1-4 several times during the 1979 and 1980 growing seasons for each organism. Analysis of variance for each measurement date indicates significant interpopulation differences in phenological development only for the earliest two measurement dates each year (May 28 and June 6, 1979; June 4 and June 12, 1980) with $F=3.0, p<.10$ for each date. In general, these populations display some but not strong ecotypic differentiation. The species of symphoricarpos, Amezanchier, and Ceratoides (in contrast to Cercocarpus and Purshia) have elaborated genetically different populations in different environments. 


\section{Symphoricarpos oreophilus}

Symphoricarpos oreophilus is represented by 15 populations in the common garden. Individual plants were measured for phenology, leaf size, leaf shape, life form, length of new stems, and dormancy. There are no significant interpopulation differ-. ences for leaf size, leaf shape, or dormancy (Table 28).

Table 28. Symphomicarpos oreophilus garden measurements. Results of one-way analysis of variance (Measurements by population source).

\begin{tabular}{|c|c|c|}
\hline \multicolumn{2}{|c|}{ Garden Measurement } & \multirow{2}{*}{$\begin{array}{l}\text { F Valuet } \\
\begin{array}{l}0.6 \\
1.0 \\
1.7\end{array}\end{array}$} \\
\hline Average leaf: & $\begin{array}{l}\text { length } \\
\text { width } \\
\text { length/width }\end{array}$ & \\
\hline Phenology: & $\begin{array}{lr}\text { May } & 21 \\
\text { Jun } & 12 \\
\text { Jun } & 18 \\
\text { Jun } & 26 \\
\text { Ju1 } & 5 \\
\text { Ju1 } & 12 \\
\text { Ju1 } & 19 \\
\text { JuT } & 28\end{array}$ & $\begin{array}{l}1.6 \\
2.0^{\star} \\
3.4^{\star \star \star} \\
2.6^{\star \star} \\
1.3 \\
1.2 \\
1.2 \\
1.2\end{array}$ \\
\hline Stem length: & $\begin{array}{lr}\text { May } & 21 \\
\text { Jun } & 12 \\
\text { Jun } & 18 \\
\text { Jun } & 26 \\
\text { Jul } & 5 \\
\text { Jul } & 12 \\
\text { Jul } & 19 \\
\text { Jul } & 28 \\
\text { Aug } & 30\end{array}$ & $\begin{array}{l}1.4 \\
2.0^{\star} \\
2.9^{\star \star} \\
3.5^{\star \star \star} \\
3.4^{\star \star \star} \\
3.3^{\star \star \star} \\
3.7^{\star \star \star} \\
3.2^{\star \star \star} \\
3.2^{\star \star \star}\end{array}$ \\
\hline Bolting stem length: & $\begin{array}{lr}\text { Jun } & 12 \\
\text { Jun } & 18 \\
\text { Jun } & 26 \\
\text { Jul } & 5 \\
\text { Ju1 } & 12 \\
\text { Ju1 } & 19 \\
\text { Ju1 } & 28 \\
\text { Aug } & 7 \\
\text { Aug } & 30\end{array}$ & $\begin{array}{l}1.7 \\
1.4 \\
1.2 \\
1.6 \\
1.7 \\
2.3 \star \star \\
2.9 \star \star \star \\
2.7 \star \star \\
4.0\end{array}$ \\
\hline Stem growth: & May 21 -Jun 26 & $3.0 * \star \star$ \\
\hline
\end{tabular}

tSignificant $F$ ratios are indicated: .05*, $.01^{\star \star}, .001^{\star \star \star}$.

Phenological advance from vegetative growth to formation of flower buds, flowering, and fruiting was measured by determining the phenological condition of each plant on a scale of 1-4 (vegetative to fruiting) eight times throughout the growing season. One-way analysis of variance for each measurement date indicates phenological differences among populations on June $12, .18$, and 26 but not in May, July, or August (Table 28).

Vegetative size and growth rate of Symphoricarpos are complicated because it produces two kinds of vegetative stems. Besides ordinary stems, some of which produce flowers, most plants also produce long stoloniferous stems laterally away from the center of the plant. These bolting stems can reach lengths greater than $1 \mathrm{~m}$ in a growing season, and they can take root at their tips thereby affecting vegetative reproduction. Three individual stems of each type on each plant were tagged and measured at intervals over the 1980 growing season. One-way variance analysis for each measurement date indicates significant differences in length from June 12 to the end of the season for ordinary vegetative stems and from July 19 on bolting stems (Table 28). Trend analysis was used to fit fifth-degree polynomials to each population's nonbolting stem growth. The linear, quadratic, and fourth-degree terms as well as the average length over the season were significantly different, which indicates that both the amounts and rates of vegetative growth are different ( $T a b l e ~ 29)$.

Table 29. Trend analysis of Symphoricarpos oreophizus stem growth.

\begin{tabular}{lcc}
\hline Term & F Value & Significance \\
\hline Linear & 136 & .00001 \\
Quadratic & 196 & .00001 \\
Cubic & 97 & .00001 \\
4th power & 6 & .02 \\
5th power & 0.4 & .54
\end{tabular}

tFitting of polynomial equations and significance testing performed by multivariate analysis of variance MANOVA program of the Statistical Package for the Social sciences.

Differences in the current year's stem lengths by the end of the season imply season-long differences in growth rate. To refine study of growth rate we inspected each population's growth curve and found that the steepest slopes occurred between May 21 and June 26. To analyze early season growth rate, the change in length over this time period was expressed in $\mathrm{mm} /$ day and tested by one-way analysis of variance (Table 28 ); significant differences were found.

Life form, analyzed in three categories (spreading, upright, and spreading and upright), for each population shows significant differences. Measurements early and late in the growing season gave consistent results; chi square values of 62.6 and 106.3 are significant at .0001 .

\section{Ame Zanchier utahensis}

Represented in the common garden are 28 populations of Amelanchier utahensis. Poor survival of three necessitated their removal from the analyses. Two types of source material were used in the common garden. For 12 sites individuals were transplanted from their native habitats; for the other 13 sites plants were grown from seed and transplanted into the common garden. Each set (referred to as the transplant and seedling populations, respectively) is analyzed separately due to 
the differences in ages and the kinds of measurements appropriate for the different material. Although identified as two gardens the seedlings and transplants occupy al ternate rows in a single large garden.

Generally, the same plant responses reported for Symphoricarpos were measured for Amelanchier with the exception of phenology. To date only one individual plant has flowered and produced fruit in the garden. Significant interpopulation response differences were found for plant height, canopy width, leaf size, leaf shape, stem length, growth rate, and dormancy (Table 30 ).

Table 30. Amelanchier utahensis garden measurements for seedlings and transplants. Results of one-way analyses of variance (measurements by population source).

\begin{tabular}{|c|c|c|c|c|}
\hline \multirow{2}{*}{\multicolumn{2}{|c|}{ Garden Mea surement }} & \multirow[b]{2}{*}{ - } & \multicolumn{2}{|c|}{ F Value ${ }^{\dagger}$} \\
\hline & & & Seedling & Transplant \\
\hline Plant height: & $\begin{array}{lr}\text { May } & 21 \\
\text { Jun } & 11 \\
\text { Jun } & 18 \\
\text { Ju1 } & 2 \\
\text { Ju1 } & 10 \\
\text { Jul } & 17 \\
\text { Ju1 } & 25 \\
\text { Aug } & 5 \\
\text { Aug } & 30\end{array}$ & - & $\begin{array}{l}2.7 \text { *t } \\
1.6 \\
1.4 \\
1.0 \\
0.8 \\
1.0 \\
0.8 \\
1.2 \\
1.4\end{array}$ & $\begin{array}{l}1.1 \\
2.2 * \\
\mathrm{~nm} \\
\mathrm{~nm} \\
\mathrm{~nm} \\
\mathrm{~nm} \\
\mathrm{~nm} \\
\mathrm{~nm} \\
\mathrm{~nm}\end{array}$ \\
\hline Canopy: & width & . & $\mathrm{nm}$ & $2.7 \star \star$ \\
\hline Average leaf: & $\begin{array}{l}\text { length } \\
\text { width } \\
\text { length/wi }\end{array}$ & & $\begin{array}{r}14.7^{\star \star \star} \\
9.4^{\star \star \star} \\
4.4^{\star \star \star}\end{array}$ & $\begin{array}{l}2.9 * \star \\
4.9 * \star \star \\
3.6 * \star \star\end{array}$ \\
\hline Stem length: & $\begin{array}{lr}\text { May } & 21 \\
\text { Jun } & 11 \\
\text { Jun } & 18 \\
\text { Jun } & 25 \\
\text { Jul } & 2 \\
\text { Jul } & 10 \\
\text { Jul } & 17 \\
\text { Jul } & 25 \\
\text { Aug } & 5 \\
\text { Aug } & 30\end{array}$ & $\stackrel{.}{.}$ & $\begin{array}{l}5.7^{\star \star \star} \\
3.8^{\star \star \star} \\
2.8^{\star \star} \\
2.8^{\star \star} \\
2.2^{\star} \\
1.8 \\
1.1 \\
1.0 \\
1.1 \\
1.3\end{array}$ & $\begin{array}{l}5.8^{\star \star \star} \\
3.2^{\star \star} \\
3.4^{\star \star} \\
3.9^{\star \star \star} \\
3.2^{\star \star} \\
2.8^{\star \star} \\
2.1^{\star} \\
1.5 \\
1.1^{-1} \\
0.7\end{array}$ \\
\hline $\begin{array}{l}\text { Total change } \\
\text { Early season } \\
\text { Late season } \\
\text { Dormancy, Octe }\end{array}$ & $\begin{array}{l}\text { height } \\
\text { ten growth } \\
\text { tem growth } \\
\text { ber } 29\end{array}$ & $\begin{array}{l}\text { rate } \\
\text { rate }\end{array}$ & $\begin{array}{l}1.2 \\
1.4 \\
5.7^{\star \star \star \star} \\
9.5^{\star \star \star}\end{array}$ & $\begin{array}{l}3.0^{\star \star} \\
2.6^{\star \star} \\
2.1^{\star} \\
3.6^{\star \star \star} .\end{array}$ \\
\hline
\end{tabular}

tSignificant $F$ ratios are indicated: $.05^{\star}$, $.01^{\star \star}, .001^{\star \star \star}$. " $\mathrm{nm}$ " means "not meàsured".

Plant heights were different on June 11 but not on May 21 for Amezanchier transplants. Seedling heights were measured 10 times during the season and were only significantly different on May 21. Canopy width was not measured for seedlings but was significantly different for the transplants. Leaf size and shape varied significantly within both gardens. Stem lengths, the same stems measured each time, were different early in the season but not past May for the transplants or July 2 for the seedlings (Table 30 ).

Growth rates expressed as total season change in height and change in stem length May 21 to July 2 and July 17 to August 30 were calculated. Late season growth ratie for the seedlings was significantly different among sources, but early season growth and total change in height were not. Change in height between May. 21 and June 11 was different among sources in the transplant populations. Also different was change in stem length June 18 to June 25 and July 17 to August 30 (Table 30). The overall growth curves of the seeding populations as analyzed by trend analys is were significnatly different.

\section{Ceratoides Zanata and Other Species}

Ecotypic differentiation in Ceratoides lanata with respect to phenology, dormancy, vegetative growth rate, and size exist. Details were provided in the progress report for 1980 .

Systematic analyses of the other species studied have only begun. Preliminary analysis shows that populations of these species al so vary ecotypically for some traits. Further discussion waits more complete analysis.

\section{Multivariate Analyses}

The univariate analyses presented for all these species typically result in dividing the species into overlapping subsets of populations. Each subset contains populations not significantly different from each other, but with significnat differences between other subsets. This is the pattern revealed by SNK and Tukey multiple range tests performed on our data. An important question, however, is, When plant response variables are taken together, are the populations any more (or less) distinct from one another? A related question is, Are there combinations of the single variables which more often than not occur together? That is, it is a priori possible that some populations with slow phenology are large vegetatively while others are small, or it might be that all populations with slow phenology are large. Answers to both questions can be approached by discriminant function analysis. This is a multivariate technique which searches for combinations of variables which maximally separate populations. It serves especially to answer the first question above, but other aspects of the technique also help answer the second question.

In general, the results are that individuals of each population can be identified with their population on the basis of a collection of the measurements made in the garden. This means that the measurements made are adequate discriminators of ecotypic variation and that most of the populations studied have a unique ensemble of genetically determined adaptations.

Results of discriminant function analysis for Symphoricarpos and Amelanchier are given in Table 31. A high percentage of variance in population membership is accounted for by the significant 
functions and a high percentage of the individual plants can be correctly assigned to their population on the basis of the measurements made in the garden. Thus, the populations are fairly distinct in common garden response.

Table 31. Summary of multiple discriminant function analysis for populations of two shrub species by measurements made in the common garden. Level of. significance is $1 \%$. Percent of plants correctly classified into their population by their original measurements also is given.

\begin{tabular}{lccc}
\hline & Symphoricarpos & \multicolumn{2}{c}{ Amelanchier } \\
\cline { 2 - 4 } & Seedling & Transplant \\
\hline $\begin{array}{l}\text { Number of } \\
\text { populations }\end{array}$ & 16 & 13 & 12 \\
$\begin{array}{c}\text { Number of } \\
\text { variables }\end{array}$ & 7 & 9 & 8 \\
$\begin{array}{l}\text { Number of } \\
\text { significant } \\
\text { functions }\end{array}$ & 3 & 4 & 2 \\
$\begin{array}{c}\text { Percent of } \\
\text { variance }\end{array}$ & 72 & 89 & 65 \\
$\begin{array}{c}\text { Percent of } \\
\text { plants } \\
\text { correctly } \\
\text { classified }\end{array}$ & 83 & 99 & 97 \\
\hline
\end{tabular}

It was noted that most of the univariate analyses for Cercocarpus populations were not significant; when discriminant analysis is applied to them, no significant discriminant functions were found. However, when applied to the original data $85 \%$ of the plants are correctly classified.

Since many of the variables given in the univariate analyses are correlated (e.g., stem length measured on the same stems from week to week), there is redundancy in the set of measures. Put another way, the number of significant differences is not necessarily significant. For the multivariate techniques used here, a subset of the variables is selected and chosen generally to include one measure from each redundant set. For example, stem length early in the season, phenology, and leaf shape each measure different properties of the organism. If they are correlated, it is a posteriori. For sequential measurements the amount of correlation between successive dates is high but drops as the time interval increases; therefore, early and late season stem lengths and phenologies are also included.

Specific results for Symphoricarpos are given in Table 32. Discriminant function analysis is closely related to but more general than multiple regression. The standardized discriminant function coefficients are similar to standardized regression coefficients and interpreted in the same way. In the table the coefficients with the largest absolute values have been underlined to aid in interpretation. Values for each function are mainly determined by these variables.

Table 32. Standardized discriminant function coefficients for Symphoricarpos oreophilus on three discriminant functions. $t$

\begin{tabular}{|c|c|c|c|}
\hline \multirow{2}{*}{ Plant Measurement } & \multicolumn{3}{|c|}{ Function } \\
\hline & 1 & 2 & 3 \\
\hline Bolting stem length, Aug 30 & .668 & -.214 & -.413 \\
\hline Average leaf length & .492 & .391 & .277 \\
\hline Early growth & .188 & .562 & -.178 \\
\hline Stem length, Aug 30 & .321 & -.801 & .779 \\
\hline Leaf shape & .110 & .473 & .443 \\
\hline Phenology, Jun 18 & -.312 & -.719 & $\underline{1.190}$ \\
\hline Average phenology & .165 & .096 & -.856 \\
\hline
\end{tabular}

tUnderlining numbers identifies the coefficients with the largest absolute values.

The first function for symphoricarpos measures leaf size and final bolting stem length. The second is contributed to by several variables: final length of ordinary stems, early growth rate, and early phenology. The third function is contributed to in opposite ways by early and average phenology. Also contributing are stem length and to a 1 imited extent leaf shape.

Similar results are given for Amezanchier in Table 33 and 34 . Plant height contributes to three of the functions for Amelanchier seedlings. Growth in height and final stem length contribute to the second but in opposite ways from height and dormancy. Leaf shape and early stem length contribute to the third function and are opposite in effect. Height growth and leaf shape are inversely related to Function 4 while late season stem length and leaf length are positively related. Interpretation of these results is not straightforward; populations tend to have different mixtures of these characteristics.

Leaf measurements dominate both Amelanchier transplant functions. Growth in height contributes to the first; stem length on May 21, to the second. other variables have less significance on both. When the leaf measurements are dropped and the analysis repeated, some classificatory power is lost, with only $71 \%$ of the organisms correctly identified by the remaining measures. 
Table 33. Standardized discriminant function coefficients for Amelanchier utahensis seedling populations on four discriminant functions. $\dagger$

\begin{tabular}{|c|c|c|c|c|}
\hline \multirow{2}{*}{ Plant Measurement } & \multicolumn{4}{|c|}{ Functions } \\
\hline & 1 & 2 & 3 & 4 \\
\hline Plant height, Aug 30 & $\therefore 756$ & -1.332 & 1.012 & .499 \\
\hline Average leaf length & -.951 & .316 & .533 & .618 \\
\hline Growth in height & -.226 & .991. & -.575 & -1.003 \\
\hline Late sea son stem growth & .186 & -.704 & .183 & .757 \\
\hline Stem length, Aug 30 & .206 & .673 & .007 & .030 \\
\hline Dormancy & -.438 & -.759 & -.072 & -.229 \\
\hline Leaf shape & -.057 & -.187 & .657 & -.749 \\
\hline Stem length, May .21 & -.327 & -.254 & -.623 & -.273 \\
\hline Insect damage & -.321 & -.057 & .135 & .378 \\
\hline
\end{tabular}

Hnderlining numbers identifies the coefficients with the largest absolute values.

Table 34. Standardized discriminant function coefficients for Amelanchier utahenisis transplant populations on two discriminant functions. $t$

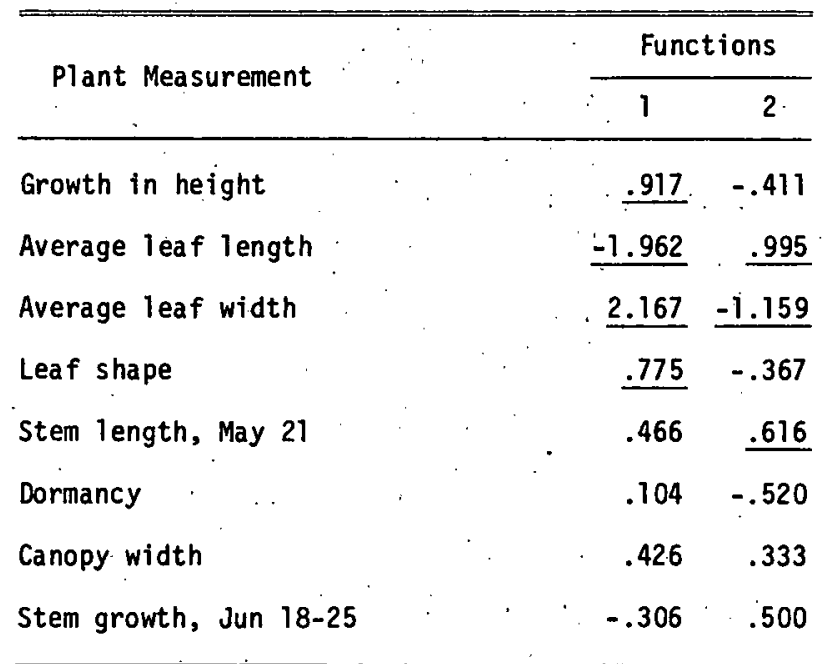

tUnderlining numbers identifies the coefficients with the largest absolute values.

\section{Discussion}

\section{Correlation with the Environment}

Symphoricarpos, Amelanchier, and Ceratoides have elaborated ecotypes, but not in the same way. There are obvious as well as subtle similarities. and differences. Our purpose here is to discuss in a general way three patterns of adaptation, especially as they relate to reclamation problems in the arid West. It is convenient to divide the many different plant responses evidencing genetic differences into three categories: plant stature, growth rate, and phenology. Regarding reclamation and the project of matching appropriate ecotypes to reclamation situations, it is important to understand the particular environments which select certain plant traits. We have collected information on and measured the environments of each population's collection site including elevation, annual precipitation, warm-season precipitation, average annual temperature, growing season length, insolation pattern, slope steepness, and slope direction. Correlation of these factors with the three major response categories is the first kind of analysis we have attempted for answering the question, To what differences in envirorment do differences in plant responses relate?

Since each collection site has only a single value for each environmental measure, the means of each population's garden response measures are used. Compared to analysis of the garden response data, the degrees of freedom for this analysis are greatly reduced. Only significant correlations are discussed in interpreting each of the three major response categories.

Plant stature, or size, varies genetically across populations of Ceratoides (discussed in the progress report for 1980), Symphoricarpos, and Amelanchier. It directly reflects the organism's ability to occupy space and utilize resources from the environment. The lateral spread of symphoricarpos, measured by bolting stem length, has an obvious influence on this organism's size. It is positively correlated with length of growing season $(r=.55)$ and warm-season precipitation $(r=.56)$. Large plants come from longer season and more mesic environments. Amelanchier stem length is likewise correlated with growing season length $(r=.59)$. Important garden response differences for Amelanchier are leaf size and shape. Leaf length is correlated with warm-season precipitation $(r=.56)$ and negatively related to growing season length $(r=-.57)$ and average annual temperature $(r=-.59)$. Leaf widths are similarly correlated.

Large leaf length to width ratios indicate elongated leaves, and low ratios indicate more isodiametric leaves. More mesic exposure (e.g., northeast-facing rather than southwest) is strongly correlated with leaf shape $(r=.86)$. Rounder leaves are more efficiently cooled and occur in sites with greater insolation. In general larger, longerleaved organisms come from more mesic environments.

Potential plant productivity is measured by growth rate. The growth rate of symphoricarpos is negatively related to an index which measures the insolation environment in terms of equivalent degrees of latitude $(r=-.50)$. Maximum growth rates occur in enviornments with a more southerly insolation pattern. Change in height of Amelanchier in the garden is inversely related to average annual temperature $(r=-.57)$. Maximum growth rates occur in plants derived from a cooler environment.

Whereas stature and growth rate relate directly to the survival of the individual organism, 
phenology is important for survival of the population and relates to the long-term occupancy of a site. Phenological data are only available for shrubs which have reached maturity in our garden, i.e., Ceratoides and symphoricarpos.

The pattern for Ceratoides has already been discussed (progress report for 1980) and is strongly related to growing season length. Symphoricarpos phenology, on the other hand, is negatively correlated with total potential yearly insolation ( $r=$ $-.52)$ and radiation index $(r=-.54)$. More advanced phenology is attained by populations drawn from areas with lower insolation and therefore a more mesic environment.

These relationships of the three major response patterns to the environment, although significant, are taken with caution. The reduced nature of the data, giving fewer significant and mostly low correlations, indicates that more study is needed. A tentative conclusion is that moisture, length of growing season, and temperature of potential reclamation sites need to be considered when identifying appropriate ecotypic sites for reclamation. We are currently working on further analyses of ecotypeenvironment relations, including getting more site/ ecotypic combinations and investigating nonlinear and multiple relationships among the variables.

\section{Interpretation for Reclamation}

Although tentative, our results are in accord with a well developed body of biology articulated by Grime $(1977,1979)$ in his studies of plant adaptations. Our discussion can best be given using his categories, especially as they relate to the major factors for individual plant survival (i.e., size and growth rate rather than phenology).

Grime, in his studies of plant adaptation, has gathered an impressive amount of information on hundreds of plant species. He identified three primary sets of characteristics (or "strategies"), different mixtures of which are possessed by different plant species or ecotypes. They are: (1) competitive, (2) stress tolerant, and (3) ruderal. The first two, and perhaps all, are relevant to our ecotype studies. Competitors are adapted for living in productive environments and have the ability to capture ample resources from the environment. The presence of other organisms is their chief challenge; control of space from which to gather resources is their stragegy. Stress tolerators are adapted for living in undisturbed, unproductive environments with various kinds of stress. They have the ability to capture and conserve scarce resources. The difficulty of accumulating biomass in severe environments is their challenge; survival, opportunistic exploitation, and husbanding resources is their strategy. Ruderals, the weeds and colonizers, are adapted to productive yet disturbed habitats. Destruction of biomass is their problem; rapid, prolific reproduction and efficient recolonization is their strategy. The competitive-stress tolerance differences have important application to our data.

One point in the above sketch of adaptive differences needs further expression. Disturbance can readily be classified as a kind of stress, but Grime is careful to distinguish disturbance from stress. Stress relates to any feature of the environment which limits biomass production. Included are aridity, extreme temperature (hot or cold), low fertility, low light, and presence of toxins. Disturbance relates to any factor which destroys or removes part or all of the biomass already produced. Included are destruction due to grazing, trampling, frost, desiccation, and erosion. We will maintain this distinction in our discussion.

Grime identifies a constellation of plant characteristics for each of the primary adaptive types. Competitors can rapidly proliferate absorptive surfaces for resource exploitation. This includes both root and shoot systems for the capture of nutrients, water, light, and carbon dioxide. Competitors are large plants able to occupy space. Stress tolerators on the other hand are typically smaller plants with slower growth rates and various other morphological but mostly physiological adaptations relating to the sort of stress offered by their environment. Ruderals are fast growing organisms but organisms that quickly deploy resources to reproduction when necessary. There are a number of other associated characteristics for these types, but these are the most relevant to our data.

The primary adaptive modes are seen by Grime as representing the poles of a continuum of adaptive types corresponding to varying environments. That is, there are several intermediate strategies. It is true that an organism cannot optimize both large size and small size, but intermediates are possible.

The main reason for referring to Grime's work is that it gives a biologically useful way to conceive the different measures made on the ecotype materials in the common garden. It can simplify the large number of individual measurements we have by allowing us to put them into two or three categories. Also, known biological meanings can be assigned to the measurements. Plant adaptation with respect to competition, stress and reproduction is al so directly related to disturbed reclamation environments.

With respect to our data, we take the characteristics of more competitive versus more stress tolerant plants to be our various measures of plant size and growth rate, including stem length, plant height, canopy width, leaf size, and vegetative growth rate. These are in fact close to the measures Grime has used. Accordingly, on the competitive to stress tolerant continuum are plants with large size and fast growth rates versus small plants with slow rates. Further, the competitive to stress tolerant continuum corresponds with productive to stressed environments. Notice that there will be several such environmental gradients depending on the kind of stress involved $\{i . e$. , moisture, nutrients, light, and toxins).

In our analysis so far, the competitive to stress tolerant range of ecotypes apparently corres ponds to a moisture stress gradient and to a growing season length gradient. This is in accord with Grime since it is more difficult to accumulate biomass with water limiting or in shorter seasons. We believe that the environments of prospective reclamation sites which vary in these two respects should be taken into account and appropriate ecotypes used, namely populations from sites similar in moisture conditions and season length. 
We have yet to investigate other stress gradients but are preparing to extend our anaiys is by studying nutrient and toxin stress gradients of potential reclamation sites and by studying ecotypic response on these gradients. We are also analyzing the data necessary to place populations in a competitive versus ruderal context and their corresponding relation to degrees of disturbances likely to be present in reclamation habitats (e.g., grazing and erosion).

With an understanding of these relationships of plant material to stress and disturbance, problems in reclamation can be dealt with on the assumption that any reciamation site will lie somewhere along a stress or disturbance gradient. If it is true that populations with different characteristics are adapted to different segments of these gradients, then different reclamation source materials need to be utilized. Our information shows that this is apparently true for Ceratoides, Symphoricarpos, and Amelanchier, especially with respect to moisture and season length.

\section{PHYTOSOCIOLOGICAL STUDIES}

\section{Objectives}

The major objectives of this portion of our study are:

1. To describe the naturally occurring vegetation in the Piceance Basin and understand its relationship to the environment

2. To present the vegetation-environmental complex in a manner suitable for planning arid land reclamation

The major portion of our vegetation studies are completed and have been reported earlier (see progress reports for 1978 and 1979 for sampling and analytic methods and 1980 for general conclusions). It is appropriate to summarize here our major findings.

\section{Results and Discussion}

The most useful way to present our conclusions concerning the initial objective is to first des-. cribe the ways in which environments of the communities of the Piceance Basin differ from those of the mid elevation sagebrush community at the Intensive Study Site. If reclamation is to proceed scientifically on different landscapes within the oil shale region, the different environments under which reclaimed communities are to exist must be known.

Since actual observations of the environmental causes of community variation are impossible to make, our strategy is to interpret existing vegetation variation as it is correlated with environment. Principal component analysis of community composition (over 130 communities were sampled) reveals the most important dimensions of variation within vegetation across the landscape. Relationships among these dimensions and independently sampled environments of the communities are revealed by using discriminant function analysis.

The most important environmental factors to which vegetation is responding are found to be precipitation, growing season water stress, dormant season water stress, percent slope, and radiation index. (See progress report for 1980 for elaboration.) These are important because they reflect the general moisture environment of organisms. Actual precipitation is strongly correlated with elevation and is the single most important environmental factor accounting for community differences in the Piceance Basin. Seasonal water stress reflects other aspects of the environment relevant to the loss of water from a site. Slope, insofar as it is related to mo isture, reflects differences in runoff, runon, and chance for deep percolation. Substrate stability and depth are also functions of slope. Radiation index (equivalent solar latitude was used here) is a measure of the yearly insolation pattern of specific sites. Biologically it is important in water and heat balance. Any reclamation of sites different from the Intensive Study Site (or any other research site) must take account of the differences in precipitation, water stress, slope, and insolation pattern.

Ecologically the most sound way to deal with these differences is to reestablish reclamation communities already proven to be adapted to a specific environmental regime. For this objective we have developed a model which predicts comunity type from the environmental features of specific sites to be reclaimed. The model is presented in the form of a user's guide and is available from the authors. Complete instructions are given for a user to determine the potential terminal vegetation of sites within the Piceance Basin. Steps in using the model are: (1) measuring or determining environmental features of the site to be reclaimed, that is, percent slope, direction of slope, soil texture, soil stoniness, and elevation, (2) calculating or reading from tables the values of seven environmental scalars based on the measurements taken, and (3) evaluating one of two sets of equations in terms of the site environment. This results in an estimate of the most likely community type matched to the user's site. Tables of species composition for each of the 10 communities are given to aid in reclamation design. A brief description of statistical and other properties of the model is now given.

Community type as a function of environment is given in stepwise multiple discriminant function analysis. Linear combinations of the environmental variables are found which maximize the multivariate $F$ ratio between all pairs of community types. The linear. combinations are called discriminant functions. Four significant, orthogonal (uncorrelated) functions are given in Table 35. All but three of the 45 multivariate $F$ ratios are significant well below .001. The remaining ratios are significant at $4 \%, 8 \%$, and $17 \%$ for comparisons of the grassforb hillside community with dry grass hillside, dry herb-shrub hillside and pinyon-juniper woodlands, respectively. In fact, these communities intergrade; their recognition as types is a pragmatic division of a gradient into units accessible to reclamation users. 
Table 35. Standardized discriminant function coefficients for predicting community type in the Piceance Basin.

\begin{tabular}{|c|c|c|c|c|}
\hline \multirow{2}{*}{$\begin{array}{c}\text { Environmental Variables } \\
\text { and Statistics }\end{array}$} & \multicolumn{3}{|c|}{ Standardized Discriminant } & \multirow{2}{*}{$\frac{\text { Functions }}{4}$} \\
\hline & 1 & 2 & 3 & \\
\hline Slope & .032 & .629 & .705 & .322 \\
\hline Exposure & -.390 & -.210 & -.317 & .563 \\
\hline Soll depth & .401 & -.022 & .769 & -.590 \\
\hline Precipitation & -1.390 & -.366 & .130 & .745 \\
\hline Growing season water stress & .400 & .532 & .012 & -1.164 \\
\hline Domant season water stress & .112 & .037 & -.286 & -.557 \\
\hline Equivalent latitude & -.405 & -.286 & .485 & 1.117 \\
\hline Stoniness & -.360 & .407 & -.330 & -.193 \\
\hline Soil moisture & .008 & -.508 & .355 & .401 \\
\hline Percent of variance & 73.0 & 11.0 & 6.5 & 5.0 \\
\hline Chi square & 234.6 & 153.2 & 97.2 & 55.1 \\
\hline Degrees of freedom & 64 & 49 & 36 & 25 \\
\hline Significance & .0000 & .0000 & .0000 & .0005 \\
\hline
\end{tabular}

of the 20 or so environmental measures entered in the analysis, only nine were retained for producing maximum group separation. Note that a saturated model including all interaction and power terms was not attempted. Even though better prediction within the original data is possible, there is increasing danger of producing spurious results arising from the specific data used. To avoid this, only interactions of the basic terms which are thought to have biological significance were used (e.g., the way elevation, slope, and exposure are thought to combine to reflect water stress). The environmental features retained in the model are percent slope, soil depth, exposure index, relative soil moisture holding capacity, soil stoniness, equivalent latitude, effective precipitation, growing season water stress, and dormant season water stress. The last four are combinations (interactions) of various other measured features of the environment.

Listed in Table 35 for each environmental variable is a standardized coefficient for each function. These can be interpreted as standardized regression weights. The absolute value indicates the contribution of each variable to each function, and the sign indicates the direction of the relation. For example, Function 1 is inversely related to effective precipitation while Function 3 is related to slope $(+)$ and depth $(-)$ with effective precipitation contributing little.

When the results of the analysis were reapplied to the original data, $95 \%$ of the stands were correctly assigned to their appropriate community. Inspection of misclassified stands reveals that they are intermediate between their actual and predicted communities. No stand was misclassified into an unrelated, more distant community. Reclassification like this is routinely done in discriminant function analysis. When original data are misclassified, it is a strong reason to mistrust the model. But, the converse (as was found here) does not give equally strong credit to the model since the classification is carried out over the data from which the model was constructed. The especially high values for correct classification along with the computed significance of the functions (Table 35) are in the model's favor.

\section{Conclusions and Recommendations}

1. Ecotypic differentiation is not strongly. evidenced for the native shrubs mounta in mahogany (Cercocarpus montanus) and bitterbrush (Purshia tridentata). Barring further evidence to the contrary, a range of source materials comparable to ours from Colorado can be used interchangeably for a variety of reclamation situations suitable to these species.

2. Ecotypic differentiation with respect to competitive ability, moisture, and short growing season stress has taken place for snowberry (Symphoricarpos oreophilus), serviceberry (Amelanchier utahensis), and winterfat (Ceratoides lanata). Source materials should be selected with moisture and seasonal environments similar to the reclamation site to best ensure individual plant survival.

3. Ecotypic differentiation with respect to the timing and amount of phenological development also exists in snowberry and winterfat as related to the radiation environments and growing season length, respectively. Reclamation source material from sites comparable in these respects is recommended to best ensure long-term survival of the populations.

4. Plant communities are distributed on the landscape largely in response to moisture factors. Both the amount of precipitation and the stress of evaporative removal are important. Reclamation should consider seriously the moisture environments of sites to be reclaimed and use appropriate species combinations.

5. Prediction of potential plant communities from easily measured environmental features is pospossible. Reclamationists can be provided a user's guide for making these predictions. Reclamation design should include reference to particular species combinations best suited to particular sites.

\section{LITERATURE CITED}

Grime, J. P. 1977. Evidence for the existence of three primary strategies in plants and its relevance to ecological and evolutionary theory. Am. Nat. $111(982): 1169-1194$.

Grime, J. P. 1979. Plant strategies and vegetation processes. John Wiley \& Sons, Inc., New York. 222 p.

\section{AVAILABLE PUBLICATIONS AND/OR ABSTRACTS}

Ward, R. T., and W. L. Slauson. 1979. Ecotypic differentiation in shrubs related to gradients 
of environment and vegetation in the Colorado oil shale lands. Annu. Meet., Ecolog. Soc. Am. Bul1. (Abstr.)

Slauson, W. L., J. R. Richards, and R. L. Dix. 1980. Prediction of vegetation from landscape features in the Piceance Basin, Colorado.

Annu. Meet., Pacific Div. AAAS. (Abstr.)

Slauson, W. L., and R. T. Ward. 1981. Ecotypic variation in winterfat (Ceratoides zanata) and other species in relation to reclamation in $0 i l$ shale lands. Reclam. Rev. Submitted. 


\title{
SELECTION OF NATIVE GRASSES AND LEGUMES FOR IMPROVED REHABILITATION
}

\author{
Robin L. Cuany, Walter W. Padilla, Robert S. Zemetra, and Nancy 0leski \\ Department of Agronomy \\ Colorado State University \\ Fort Collins, Colorado 80523
}

\section{OBJECTIVES}

This research involves the development of improved plant material for the oil shale region by testing and selective breeding of a small number of important species. The hypothesis is that a few improved strains of each species could be developed from genotypes of local or regional origin which could be adapted in the rehabilitation of diverse, stable (self-sustaining), and functional ecosystems. The improvements sought are in those traits important to early growth and land stabilization, such as seed size and lowered dormancy which contribute to rapid establishment and better seedling vigor, as well as the capacity to produce useful quantities of seed. This must be achieved without losing the ecological adaptation or al tering the role played by these grasses and legumes in advanced successional stages.

Research results dealing with selection and breeding of plant materials are discussed in light of the following. four objectives. which are sequential stages of the work.

1. Collect and assemble germplasm sources.

2. Evaluate spaced plants in two nurseries and clonal progagules or progenies under controlled stress for various seed and plant characteristics; produce test seed.

3. Evaluate seed progenies at the Intensive Study site and satellite field plantings for survival, vigor, and adaptation.

4. Use suitable breeding procedures for recombination of parents selected by progeny testing to develop improved strains.

PROGRESS $1976-1980$

The two grasses which have been studied have reached Stage 4 , including the planting of one synthetic variety of western wheatgrass (Agropyron smithii Rydb.) and one of Indian ricegrass (Oryzopsis hymenoides [R.+S.] Ricker) in comparison trials with breeding stocks and cultivars from e] sewhere. These synthetics were based on the evaluation tests in objectives 2 and 3 and represent our best judgment as to combinations of traits for successful rehabilitation use in the Piceance Basin.

The accession, testing, and multiplication of genotypes of the two native legumes in this program, sweetvetch (Hedysamon boreale Nutt.) and lupine (Lupinus argenteus Pursh, L. caudatus Hell., and related taxa), have reached the test row stage for performance and direct multiplication.

other work which is essentially completed is a study of methods to reduce dormancy in Indian ricegrass, including the use of two cycles of selection for genetically lowered dormancy (the second cycle of which will set seed in 1981). An ongoing study comparing the growth and $\mathrm{N}$-fixation ability of several strains of introduced and native legumes completed its second growing season in 1980 and is due for more detailed acetylene reduction assay in different parts of the 1981 growing season.

\section{Collection of Germplasm}

In the beginning of any plant improvement program the germplasm sources have to be assembled from previous cultivars (if any) and geographically logical areas. In the present project there was considerable attention paid to collections in the Piceance Basin and adjacent regions. There may be ecotypic differences based on the contrasting precipitation patterns of the eastern and western slope for the two grasses which grow in both areas (Asay et al. 1978). In practice this distinction has not been correlated with their test success. Some accessions were obtained by correspondence with Plant Materials Centers of the Soil Conservation Service (SCS-USDA); others were collected as seed or plants by our project. In the 1977 season many locations from which we desired seed failed to mature any seeds, and the alternative of digging plants (which was used for western wheatgrass in 1978) had proved impractical in the lupines because of their deep, yet essential, tap roots. For this reason some native collections have not been evaluated exactly in parallel with earlier accessions through the test sequence. With the legumes we sought to short cut this delay by planting test rows at the Intensive Study Site at the same time as multiplication rows; i.e., attacking objectives 2 and 3 simultaneously. With all the species, flowering and adequate seed setting is delayed until at least the year following that of germination and 
establishment so that when an original collection is too small for replicated testing, there is a delay until it is in adequate supply. In 1979 some native ricegrass was put into row tests, and in 1980 native western wheatgrass types were harvested for seed--as also were some of the ricegrass types from $0 r$. Ward's ecotype garden and more adequate seed lots from our ricegrass nurseries.

\section{Evaluation of the Sources in Nurseries}

Grasses

\section{Western Wheatgrass}

Spaced plant nurseries were established in 1974 and 1976 for cultivars and accessions of western wheatgrass at Fort Collins (FC); in 1977 at the Environmental Plant Center in Meeker (M); and for native accessions of this species at both Fort Collins and Meeker in 1978. For Indian ricegrass the equivalent nurseries were established in 1977 and 1978. These nurseries have served to provide data on spread, flowering time, height, seed yield, and seed size (100-seed weight) for individual plants which were then ranked for these several traits. Those plants with desirable (usually maximal) expressions of these traits were considered as "selected" parents; and the seed harvested from them used in progeny tests, row-planted in two or three replications in the Intensive Study site (0bjective 3) for evaluation of performance and maintained for possible advancement. The best of the selected plants, now called "elite" mother plants, were divided for recombination or other controlled seed production as indicated in objective 4.

In the case of western wheatgrass, seed data from 1977 and 1978 (FC) and 1978 and 1979 (M) led to the choice of 96 elite clones out of approximately 1,735 plants in the nurseries. These clones had good spread and plant vigor, high culm rating without lacking in leafiness, seed yield over $10 \mathrm{~g}$ per plant (usually over $30 \mathrm{~g}$ ), and 100 -seed weight over $500 \mathrm{mg}$. These selection cut-off levels compare with average seed yields of $10 \mathrm{~g}$ and $11 \mathrm{~g}$ at $F C$ and $M$ and average seed weights of $447 \mathrm{mg}$ and $442 \mathrm{mg}$ at $F C$ and $M$ (Table 36 ). The objective of seeking high seed yield is important to successful economic multiplication as well as having enough seed to plant several test rows (Schaff 1976). The advantage of high seed weight is believed related to vigorous germination, emergence, and early growth in the suboptimal environment of a disturbed soil being reclaimed (Roger 1954).

Variation for many traits, including the above, was found to be significant among the 40 different sources. An example of seed data from Meeker in 1979 is shown in Table 37. Traits were correlated from year to year and nursery to nursery. This indicates a genetic component to the variation and also suggests. that the variability from plant to plant within a source is also partly genetic in nature (Padilla 1978). It may be noted that almost every source has some high-seed-weight plants in it and the ecological values of many sources can be retained. The heritability of traits suggests breeding progress that can be made by recombining plants selected for these characters into a synthetic variety based on Piceance Basin performance in the progeny tests.

Table 36. Extremes and averages for 1,735 western wheatgrass nursery plants and their 96 selected mother plants for strainbuilding.

\begin{tabular}{|c|c|c|c|c|c|c|c|}
\hline \multirow{2}{*}{\multicolumn{2}{|c|}{ Character }} & \multicolumn{3}{|c|}{ Seed Yield $(g)$} & \multicolumn{3}{|c|}{100 -Seed Wt $(\mathrm{mg})$} \\
\hline & & Low & Mean & High & Low & Mean & High \\
\hline $\mathrm{FC}$ & $\begin{array}{l}\text { nursery } \\
\text { selections }\end{array}$ & $\begin{array}{r}0 \\
30\end{array}$ & $\begin{array}{l}10 \\
41\end{array}$ & $\begin{array}{l}82 \\
82\end{array}$ & $\begin{array}{l}208 \\
501\end{array}$ & $\begin{array}{l}447 \\
554\end{array}$ & $\begin{array}{l}685 \\
685\end{array}$ \\
\hline M & $\begin{array}{l}\text { nursery } \\
\text { selections }\end{array}$ & $\begin{array}{r}0 \\
10\end{array}$ & $\begin{array}{l}11 \\
24\end{array}$ & $\begin{array}{l}80 \\
80\end{array}$ & $\begin{array}{l}251 \\
501\end{array}$ & $\begin{array}{l}442 \\
567\end{array}$ & $\begin{array}{l}752 \\
752\end{array}$ \\
\hline
\end{tabular}

Native collections (by seed or plants) made in 1976 were transferred to a native western wheatgrass nursery in Fort Collins and subsequently propagated into a new six-replication plot in fall 1977 . Slow growth of these plants in 1978 and 1979 coupled with limited resources deferred a harvest of these 42 types until August 1980, and the seed awaits processing. Small plant size and rather low reporductive ability would seem to limit their potential, compared with other materials tested in the program.

In spring 1978 another group of plants, collected in areas close to the Piceance Basin, was placed in a seed production nursery at Meeker. Seed produced in 1979 were, in most cases, less than $8 \mathrm{~g}$ per four plants; a second crop was harvested in August 1980. Seed of these 10 collections al so awaits processing. Six of them were true western wheatgrass types, three were the related but higher-elevation thickspike wheatgrass (Agropyron dasystachyrom), and one came from a clump which had slender (Agropyron trachycaulion) and western wheatgrasses mixed.

\section{Indian Ricegrass}

Spaced plant nurseries established at Meeker and Fort Collins in 1977 yielded plant and seed data in 1978 and 1979. The seed yields and 100seed weights are given for Fort Collins in 1979 (not previously reported) in Table 38. Other data sets have shown significant differences among sources in traits such as plant shape, panicle number, flowering data, 100-seed weight, and seed yield per plant. As in the case of western wheatgrass, there were also differences from plant to plant within the sources; and we have capitalized on these by selecting individual parents, 34 of whose progenies were seeded in replicated row tests in the Intensive Study Site in November 1978 and Apri1 1979. The outcome of these tests is discussed below as accomplishments under 0bjectives 3 and 4 .

Further inspection of Table 38 shows that besides the significant differences among sources, in almost every source there are some high values for the two seed traits, indicating that selections 
Table 37. Seed traits of 1979-harvested western wheatgrass at the nursery in Meeker showing range among individual plants.

\begin{tabular}{|c|c|c|c|c|}
\hline \multirow[t]{2}{*}{ Source } & \multicolumn{2}{|c|}{$\begin{array}{c}\text { 100-Seed Wt } \\
(\mathrm{mg})\end{array}$} & \multicolumn{2}{|c|}{$\begin{array}{c}\text { Seed Yield/Plant } \\
(g)\end{array}$} \\
\hline & Ave. & Range & Ave. & Range \\
\hline \multicolumn{5}{|l|}{ Cultivars } \\
\hline $\begin{array}{l}\text { Arriba } \\
\text { Barton } \\
\text { Flintlock } \\
\text { Mandan } 456 \\
\text { Rosana }\end{array}$ & $\begin{array}{l}589 \\
492 \\
451 \\
465 \\
544\end{array}$ & $\begin{array}{l}501-668 \\
398-660 \\
311-571 \\
367-551 \\
482-631\end{array}$ & $\begin{array}{r}10.0 \\
21.7 \\
7.1 \\
14.5 \\
16.3\end{array}$ & $\begin{array}{l}0.3-20.4 \\
2.4-52.1 \\
0.3-40.3 \\
1.0-44.2 \\
1.6-33.7\end{array}$ \\
\hline \multicolumn{5}{|l|}{ Accessions } \\
\hline $\begin{array}{l}A-13081 \\
A-16592 \\
A-16634 \\
A-16931 \\
B N 19823 \\
B N 19824 \\
C-27 \\
N M-429 \\
P-727 \\
E 6-37\end{array}$ & $\begin{array}{l}505 \\
602 \\
422 \\
407 \\
484 \\
501 \\
546 \\
451 \\
522 \\
526\end{array}$ & $\begin{array}{l}435-612 \\
426-788 \\
300-547 \\
360-494 \\
339-595 \\
386-596 \\
387-741 \\
358-612 \\
402-628 \\
356-666\end{array}$ & $\begin{array}{r}13.2 \\
10.4 \\
8.9 \\
17.0 \\
2.3 \\
16.7 \\
7.5 \\
26.8 \\
10.3 \\
7.2\end{array}$ & $\begin{array}{l}0.8-28.5 \\
0.5-32.4 \\
0.8-41.1 \\
0.9-26.8 \\
0.1-4.4 \\
1.2-53.0 \\
0.2-19.8 \\
0.9-63.3 \\
1.3-24.2 \\
0.3-25.7\end{array}$ \\
\hline \multicolumn{5}{|l|}{ Collections } \\
\hline $\begin{array}{l}\text { Colo City } \\
\text { Tincup } \\
\text { TS-11-11/15 } \\
\text { TS-11-16/20 } \\
360 \\
361 \\
370 \\
372 \\
378 \\
385 \\
387 \\
390 \\
399 \\
440 \\
525\end{array}$ & $\begin{array}{l}501 \\
503 \\
497 \\
487 \\
475 \\
505 \\
593 \\
458 \\
547 \\
375 \\
456 \\
481 \\
420 \\
376 \\
485\end{array}$ & $\begin{array}{l}293-670 \\
419-619 \\
316-617 \\
320-722 \\
362-557 \\
404-565 \\
380-736 \\
301-608 \\
443-632 \\
263-653 \\
384-595 \\
352-665 \\
304-535 \\
261-492 \\
325-584\end{array}$ & $\begin{array}{r}13.3 \\
17.0 \\
29.1 \\
6.3 \\
7.8 \\
13.5 \\
8.2 \\
8.3 \\
14.6 \\
2.6 \\
7.0 \\
7.1 \\
7.6 \\
4.3 \\
5.9\end{array}$ & $\begin{array}{l}2.0-49.8 \\
1.7-43.0 \\
0.1-45.7 \\
0.4-19.8 \\
0.3-18.2 \\
0.2-37.2 \\
1.8-17.4 \\
0.5-20.0 \\
7.1-31.4 \\
0.1-5.8 \\
0.6-48.3 \\
1.6-13.9 \\
0.3-21.8 \\
0.3-19.6 \\
0.2-20.6\end{array}$ \\
\hline Mean & 489 & & 10.8 & \\
\hline LSD (05) & 91 & & 10.2 & \\
\hline Significance & $\star \star \star \dagger+$ & . & $\star \star^{5}$ & \\
\hline
\end{tabular}

tsignificant at $p<.001$.

ssignificant at $p<.01$.

could be made while preserving diversity of germplasm. Even the collections from the Piceance Basin have a few high seed weights, though their average seed yields are lower than the cultivars or SCS accessions. Other native collections that have been put out as nursery-spaced plants yielded some seed in 1979 that was used in an eight-entry test at the Intensive Study Site. More of these plants in Dr. Lang's (University of Wyoming) collection and other Colorado and Piceance Basin types, that have not previously been includable in critical site tests, have set seed in 1980 in the Fort Collins nursery, although limited resources have delayed our presentation of seed weight and yield data. A list of these collections is presented in Table 39. The table includes those collections harvested from Dr. Ward's (Department of Botany and Plant Pathology, CSU) ecotype garden during the 1980 season, following their phenology observations.

Table 38. Seed traits of 1979-harvested Indian ricegrass at the nursery in Fort Collins showing range among individual plants.

\begin{tabular}{|c|c|c|c|c|}
\hline \multirow[t]{2}{*}{ Source } & \multicolumn{2}{|c|}{$\begin{array}{c}100-\text { Seed Wt } \\
\text { (mg) }\end{array}$} & \multicolumn{2}{|c|}{$\begin{array}{c}\text { Seed Yield/Plant } \\
(g)\end{array}$} \\
\hline & Ave. & Range & Ave. & Range \\
\hline \multicolumn{5}{|l|}{ Cultivars } \\
\hline $\begin{array}{l}\text { Nezbar } \\
\text { Paloma } \\
\text { Sharps } \\
\text { Warners }\end{array}$ & $\begin{array}{l}365 \\
462 \\
423 \\
351\end{array}$ & $\begin{array}{l}296-411 \\
381-539 \\
297-495 \\
279-408\end{array}$ & $\begin{array}{r}15.6 \\
10.5 \\
6.5 \\
18.7\end{array}$ & $\begin{array}{l}3.4-22.4 \\
0.2-18.1 \\
3.1-13.2 \\
1.2-31.6\end{array}$ \\
\hline \multicolumn{5}{|l|}{ Accessions } \\
\hline $\begin{array}{l}\text { Breeders } \\
M-700 \\
N M-15 \\
N M-168 \\
P-15597 \\
P-15598 \\
P-15650 \\
P-15657\end{array}$ & $\begin{array}{l}357 \\
293 \\
385 \\
456 \\
316 \\
366 \\
293 \\
317\end{array}$ & $\begin{array}{l}344-375 \\
276-316 \\
275-464 \\
327-509 \\
162-388 \\
318-396 \\
266-332 \\
258-389\end{array}$ & $\begin{array}{r}12.2 \\
12.2 \\
7.0 \\
9.8 \\
23.4 \\
15.2 \\
15.0 \\
4.8\end{array}$ & $\begin{array}{r}0.8-23.2 \\
11.8-43.5 \\
3.0-21.8 \\
4.5-20.1 \\
1.8-38.5 \\
9.2-43.1 \\
0.5-30.8 \\
1.1-8.7\end{array}$ \\
\hline \multicolumn{5}{|l|}{ Collections } \\
\hline $\begin{array}{l}E-1 \\
P B-2 \\
P B-4 \\
S C-1\end{array}$ & $\begin{array}{l}316 \\
327 \\
268 \\
365\end{array}$ & $\begin{array}{l}285-418 \\
272-416 \\
229-286 \\
194-419\end{array}$ & $\begin{array}{l}6.3 \\
4.4 \\
1.6 \\
5.3\end{array}$ & $\begin{array}{l}0.1-21.1 \\
2.9-9.0 \\
0.8-1.6 \\
0.9-19.2\end{array}$ \\
\hline Mean & 352 & & 11.2 & \\
\hline LSD (05) & 68 & & 9.1 & \\
\hline Significance & 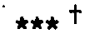 & & $\star \star \star \dagger$ & \\
\hline
\end{tabular}

tsignificant at $p<.001$.

Solutions to the Dormancy Problem in Indian Ricegrass

One of the problems with using Indian ricegrass for reclamation is seed dormancy, especially with freshly harvested seed such as ecotype collections and single-plant progenies for immediate (JulyOctober) planting turnaround. Average germination the first year has been about $5 \%$ or less, with many seedlings not coming up until the second or third spring after fall planting. This causes the reclamation specialist to use larger amounts of expensive seed. The relationship of dormancy to seed covering thickness and seed weight was analyzed as to consequences of selection for high seed weight. Two remedies were followed for the treatment of seed to plant tests: chemical and mechanical scarification. Lastly, we are trying recurrent selection to shift the genetic background over to lessened dormancy, a technique used successfully by Schaaf and Rogler (1979) in green needlegrass.

A significant difference in seed covering thickness (indurated lemma and palea) was found among 15 strains of Indian ricegrass, varying from 
$42 \mu$ to $78 \mu$. Germination (i.e.; lack of dormancy) was also significantly different among strains, ranging from $0 \%$ to $8 \%$. Seed weight ranges significantly from $217 \mathrm{mg}$ to $461 \mathrm{mg}$ per. 100 seeds. None of these traits changed for any strain from the Fort Collins nursery to the Meeker nursery, suggesting genotype is more important than environment in influencing them. Seed covering thickness was negatively correlated $(r=-.47)$ to germination and positively correlated $(r=.48)$ with seed weight (Zemetra and Cuany 1981). The results suggest that one can increase germination by selecting thinner seed coverings. They also imply that selecting for higher seed weight may bring a penalty in decreased germination unless simultaneous selection for seed weight and higher germination is practiced.

Table 39. Native collections of Indian ricegrass and their advance to increase nursery strain test 1978 and as individual selections to strain test 1979.

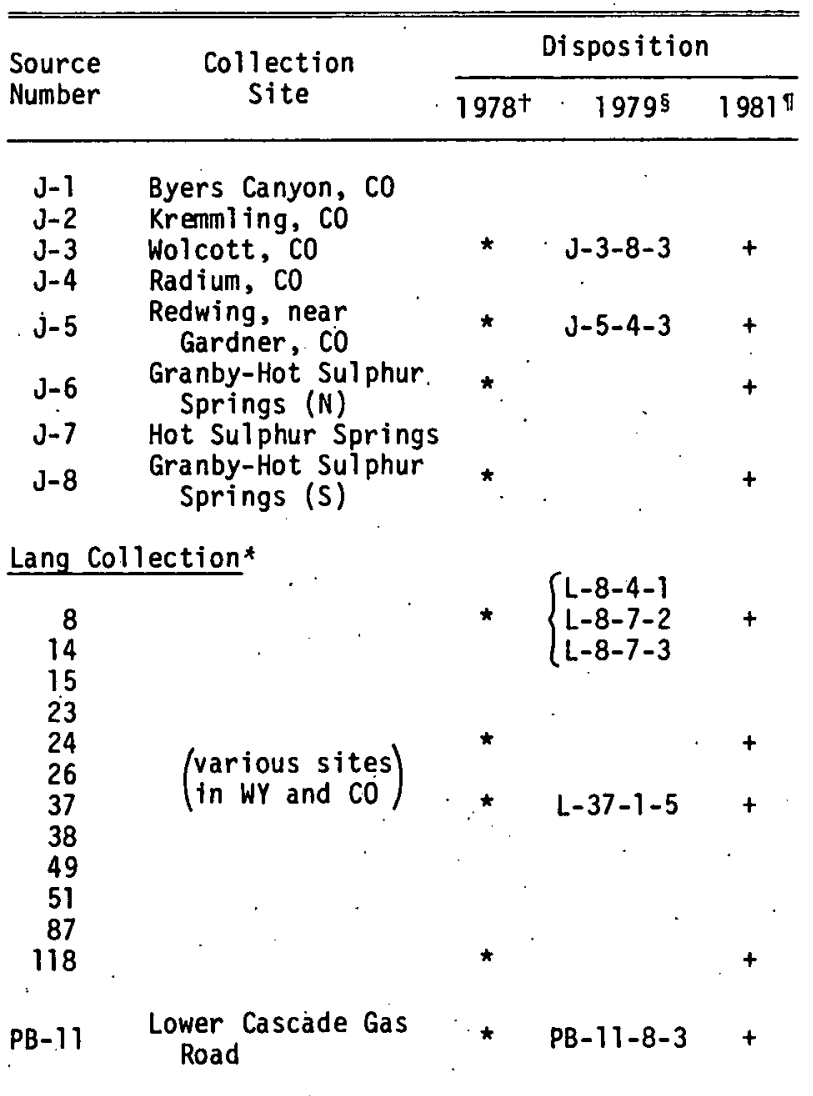

tSelected for increase based on seed weight and germination determined during winter 1977-1978. Planted at ISS April. 1978 but damaged by rodents.

5planted at ISS December 1979. Rated Jun 1980 and Sep 1980 (Table 44).

"Seed progeny available from 1980 harvest from nursery.

*Many packets had low or zero viability.

A series of experiments was carried out in an attempt to reduce the dormancy by scarifying the seed coat and weakening the lemma and palea (Zemetra et al. 1981). Four treatments (three mechanical and one concentrated sulfuric acid) were examined alone and in combination with gibberellic acid (McDonald and Khan 1978). Three ages of seed $(6,18$, and 30 months) were tested in the greenhouse in germination boxes and at the Intensive Study site in the field. Concentrated sulfuric acid and a modified commercial scarifier most effectively increased germination in the greenhouse. Gibberellic acid enhanced germination in the younger (fresher) seeds in this environment. The rubbing machine improved germination in the field from $8 \%$ to $12 \%$ more than the other treatments. It was, however, only a modest improvement. For 30-monthold seed, germination went up from $15 \%$ to $24 \%$ by means of mechanical scarification. Concentrated sulfuric acid decreases germination about 3\%-6\% for a)1 three ages of seed in the field. The germination chamber indicated that none of the treatments affected immediate mortality, but acid-treated seed in the field may have succumbed to soil pathogens over the winter. Practical needs of a reclamation specialist may be met by mechanical scarification or the use of 30-month aged seed which will germinate 15\%-25\% in its first year without scarification.

The third approach to the dormancy problem is to select genetic variation displaying low dormancy. By doing this over two or three cycles (recurrent selection), genes for low dormancy can be concentrated in one strain. This was started by saving the few seedlings germinated in control (unscarified) greenhouse rows, about $8 \%$ for Paloma and $2 \%$ for Warners in 1978. They were transplanted to the field and produced a few seed in october which when tested were found to be completely dormant. In July 1979 these same plants yielded seed which upon testing gave an average germination percentage of 5.1 as shown in Table 40 with individual progenies ranging up to $16.7 \%$ of early-germinating seedlings. These germinated seedlings, in turn, were put into a new block for recombination among themselves, the 30 seedlings from the first five parents being surrounded by other seedlings of early germination type. The latter were derived from a bulk planting of seed from all 29 parents, in which one might expect the first 13 to have produced most of the 114 seedlings used in the border. It is hoped from this process to achieve $25 \%-40 \%$ fresh germination.

Legumes

\section{Sweetvetch}

The species Hedysamom boreale is native in the Piceance Basin as well as in Utah, Wyoming, Montana, and states and provinces further west and north to the Arctic (Northstrom and Welsh 1970). We obtained seed from Stewart and Sons in Ephraim, Utah, and planted a nursery at Fort Collins in 1977 which did not flower that year. However, it flowered but did not set any mature pods in 1978; it did both in 1979 and 1980. Out of 102 plants only 11 set a good crop of seed pods (loments), ranging from $2 \mathrm{~g}$ to $21 \mathrm{~g}$ of clean seed in 1979. In the 1980 harvest more of the plants were harvested. At least 10 plants had yields over $8 \mathrm{~g}$, ranging up to $34 \mathrm{~g}$; 100 -seed weights were $750 \mathrm{mg}$ to $1,050 \mathrm{mg}$. Assuming differences in seed-set are partly genetic, we expect progress from a second-stage nursery 
including the progeny of these productive plants. The nursery was planted in the spring of 1980 and included $15 \mathrm{plants}$ from the Intensive Study Site (ISS), 20 from E/ISS (inside the fence at ISS), 8 from Pipleine (near ISS), and 14 from the original Stewart and Sons seed lot.

Table 40. Germination (average of three replications) of fresh 1979 seed from the nondormancy recombination block in April 1980.

\begin{tabular}{|c|c|c|c|c|c|}
\hline Parentt & $\begin{array}{l}\text { Plant } \\
\text { Number }\end{array}$ & $\begin{array}{c}\text { Average } \\
\text { Germination } 5 \\
(\%)\end{array}$ & $\begin{array}{l}\text { Used in } \\
\text { the Cycl } \\
\text { (seed } 1 \\
\text { seed }\end{array}$ & $\begin{array}{l}\text { Pla } \\
\text { le-2 } \\
\text { ings } \\
\text { pare }\end{array}$ & $\begin{array}{l}\text { nting } \\
\text { Block } \\
\text { as } \\
\text { nts }\end{array}$ \\
\hline Paloma - 77 & $\begin{array}{l}71 \\
88 \\
44 \\
17 \\
10\end{array}$ & $\begin{array}{r}16.7 \\
12.3 \\
11.7 \\
11.3 \\
9.3\end{array}$ & & $\begin{array}{l}6 \\
6 \\
7 \\
4 \\
7\end{array}$ & \\
\hline Paloma-77 & $\begin{array}{r}48 \\
23 \\
16 \\
52 \\
43 \\
90 \\
2 \\
35\end{array}$ & $\begin{array}{l}9.3 \\
9.0 \\
7.3 \\
7.3 \\
6.7 \\
5.6 \\
5.6 \\
5.0\end{array}$ & $\therefore$ & & . \\
\hline Paloma- 77 & $\begin{array}{l}11 \\
14 \\
67 \\
12 \\
28\end{array}$ & $\begin{array}{l}4.3 \\
4.0 \\
3.7 \\
2.0 \\
2.0\end{array}$ & & & \\
\hline $\begin{array}{c}\text { Paloma-77 } \\
\ddots\end{array}$ & $\begin{array}{r}56 \\
68 \\
86 \\
31 \\
6 \\
32 \\
66\end{array}$ & $\begin{array}{r}1.3 \\
1.3 \\
1.3 \\
1.0 \\
0.7 \\
0.7 \\
0.7\end{array}$ & : & r. & . \\
\hline Warner -77 & $\begin{array}{l}72 \\
87 \\
59 \\
27\end{array}$ & $\begin{array}{l}3.3 \\
3.0 \\
1.7 \\
0.0\end{array}$ & $\cdot$ & & \\
\hline $\begin{array}{l}\text { Mean of } 29 \\
\text { progentes }\end{array}$ & s. & 5.1 & . & & . \\
\hline
\end{tabular}

tTotal of 29 plants which were themselves raptd germinators in January 1978.

SSeed harvested July 1979, put to germinate 26 March 1980 without any scarification. Seedings counted at 28 days.

ISeedlings from the remaining parents were used only in border area and will only contribute a little pollen to the above block.

The other area where we are attempting to produce sweetvetch seed is a set of replicated 3-m rows at EPC, Meeker. Seeding five accessions in Ocotber 1978 gave a stand of small seedlings in
1979 which were weeded several times in 1979-1980. To date these rows have not flowered, but older plants established by SCS personnel set seed there in 1980 .

Lupines

Lupine seed has been collected from many elevations in Colorado by the efforts of Stephen Kenny whose support was not primarily from the DOE contract. In 1977 a nursery of spaced seedlings was started in Fort Collins but never grew well and did not yield useful data or seed. Seed from native stands was re-collected in 1978. Nursery rows were established at the Environmental Plant Center (EPC) in Meeker instead of Fort Collins. The climate in Meeker was more similar to Piceance Basin climate than the climate in Fort Collins. Also, moisture and cultural controls are more precise at the EPC than at the Piceance Basin Intensive Study site.

Lupine taxonomy is complex and has been made more difficult by the hybridization caused through man's disturbance of roadsides, hillsides, etc. Kenny (1981) grouped his collections mainly under Lupinus argenteus and Lupinus caudatus and notices that some subspecies of $L$. argenteus were found in mesic subalpine habitats, while others were in drier areas of the montane zone. $L$. caudatus is associated with the pinyon pine/juniper and oak/ mountain mahogany zones where it. may come into contact with the drier end of the $L$. argenteus area in regions below $2,100 \mathrm{~m}$ (such as the Piceance Basin). Kenny's collections that were planted at Meeker for evaluation and seed production are listed in Table 41 under thetr ecological zone and taxon.

Several traits studied at Meeker include stand, flowering by June 23,1980 , and seed production. Since some early pods sampled were found to contain larvae (which feed on and destroy the seed), a spray treatment was launched by the manager of the EPC at our request. Only 17 out of 32 accessions produced any seed, and yields averaged only 147 seed per row (total of about 10 plants). Compared to domesticated (native or exotic) legumes, these lupines are uncooperative in regards to producing new test seed. Even the L. caudatiu accessions from altitudes similar to the center of the Piceance Basin did not produce more than 410 seed per row.

\section{Testing Source Material and Progentes in Critical Environments}

The testing of promising and elite material in critical environments (i.e., climates and soils of the ofl shale region) is the most essential step in proving which commerclal cultivars, strains, accessions, ecotypes, or single-plant progenies can succeed in the rehabllitation process. Moreover, by identifying the best mother plants in this criterion, the breeder can develop the synthetic strains which are needed for that specific task (Cuany and Wflson 1979). Since 1976 we have tested avallable sources in row-seeded trials at the Intensive Study Site, and based on those findings and the results of nursery data from Objective 2 (e.g.. Padflla 1978) we have seeded progeny tests 
in 1978 and 1979. Preliminary results of the 1978 tests were tabulated in last year's report ( $\mathrm{COO}-$ 4018-4), and the tests continued to show good survival and vigor of many progenies in 1980. Results will be discussed separately for the grasses and legumes involved.

Table 41. Origins and adaptations of lupines and seed harvested from the increase rows at EPC, Meeker, in 1980.

\begin{tabular}{|c|c|c|c|c|}
\hline \multirow{2}{*}{$\begin{array}{c}\text { Ecological Zone and } \\
\text { Species }\end{array}$} & \multirow{2}{*}{$\begin{array}{l}\text { Elevationt } \\
\text { (m) }\end{array}$} & \multirow{2}{*}{$\begin{array}{l}\text { Accession } \\
\text { Numbers }\end{array}$} & \multicolumn{2}{|c|}{ Seed Hàrvests 5} \\
\hline & & & Number & $\begin{array}{c}100-\text { Seed } W t \\
(g)\end{array}$ \\
\hline \multicolumn{5}{|l|}{ Subalpine Zone } \\
\hline $\begin{array}{l}\text { Spruce/fir } \\
\text { Lupirus argenteus }\end{array}$ & $3000-3400$ & $\begin{array}{l}422,424, \\
431,432, \\
502,632, \\
725,726, \\
728\end{array}$ & 10 & 1.1 \\
\hline $\begin{array}{l}\text { Lodgepole pine/aspen } \\
\text { tupinus argenteus }\end{array}$ & $\begin{array}{c}2400-3000 \\
i\end{array}$ & $\begin{array}{l}101,131, \\
135,142, \\
145,425, \\
521,522, \\
623\end{array}$ & $\cdot 67$ & .1 .5 \\
\hline Lupinus parviftorus & 2600 & 532 & $\ldots$ &.- \\
\hline Lupinus wyothii & 2500 & 531 & 0 & -- \\
\hline Lupinus $\times$ alpestris & $2600-2700$ & $\begin{array}{l}323,924 \\
927\end{array}$ & 40 & 1.4 \\
\hline \multicolumn{5}{|l|}{ Montane Zone } \\
\hline $\begin{array}{l}\text { Ponderose plne } \\
\text { Lupinus argenteus }\end{array}$ & $2300-2600$ & 031,945 & 200 & 1.3 \\
\hline Lupinus parviviorus & 2400 & 526 & 0 & $\cdots$ \\
\hline Lupinus $x$ alpeotris & 2300 & 302 & 25 . & 1.2 \\
\hline \multicolumn{5}{|l|}{ Footh1lls Zone } \\
\hline $\begin{array}{l}\text { Pinyon pine/ juntper } \\
\text { Lupinus anmophilus }\end{array}$ & 2100 & .232 & 0 & --- \\
\hline Lupinus argenteus & 2000 & 231 & -- & --- \\
\hline $\begin{array}{c}\text { Oak/mounta in mahogany } \\
\text { Lupinus argenteus }\end{array}$ & 2300 & $22 !$ & $\cdot-2$ & $\cdots$ \\
\hline Lupinus caudatus & $2100-2300$ & $\begin{array}{l}225,629 \\
724,826 \\
828\end{array}$ & 410 & 2.1 \\
\hline Lupinus $\times$ alpestrio & 2300 & 931 & 40 & 1.2 \\
\hline
\end{tabular}

\section{Grasses}

\section{Western Wheatgrass}

The 1976 tests used avallable seed of 5 cultivars, 7 accessions, and 10 collections, of which only the cultivars Arriba, Mandan 456, and Rosana showed superior performance. The only collection showing average promise was Tincup from above the Gunnison Valley. The first progeny test; planted in the unfavorable spring of 1978, gave only emergence data which showed the best percentage of superior progenies to have come from cultivars (pp. 208-210, C00-4018-3).

The November 1978 progeny test of 49 entries in three replications and the Decmeber 1979 progeny test of 62 entries in two replications (planted in the center panel of the legume plot on a mixed topsoil-subsoil base at the ISS) have performed well and yielded useful comparative data. Scores of emergence, survival, and vigor were made in October 1979 and May 1980 for the former test and in June 1980 and September 1980 for the latter. Correlations between the two scores in each test were highly significant at .42 and .62 , respectively. Choice of superior parents, without listing all the parents (Table 37, p. 56, C00-4018-4, for an example), resulted in 26 parents being chosen out of 49 and 35 out of 62 for an overall percentage for superior of $55 \%$. Table 42 shows that a somewhat higher percentage for superior progenies was found among those which came from cultivars (representing an improvement over the straight cultivars). On the other hand, the proportion of superior parents among those from collections increased in the second growing season from the November 1978 test. Unfortunately, it has not yet been possible to adequately test (in the Piceance Basin) seed progenies from the 1978 native collection of western wheatgrass.

Table 42. Western wheatgrass progeny tests at the Intensive Study Site: proportion showing superior performance.

\begin{tabular}{|c|c|c|c|c|c|c|}
\hline \multirow{3}{*}{ Type of Parent } & \multicolumn{3}{|c|}{$\begin{array}{l}\text { 1st Group } \\
\text { Nov } 1978\end{array}$} & \multicolumn{2}{|c|}{$\begin{array}{l}\text { 2nd Group } \\
\text { Dec } 1979\end{array}$} & \multirow{3}{*}{$\begin{array}{c}\text { Overall } \\
\text { Superior } \\
(x)\end{array}$} \\
\hline & & $\stackrel{\stackrel{g}{\leftrightarrows}}{\bar{\Xi}}$ & 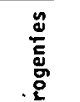 & & 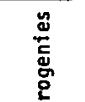 & \\
\hline & 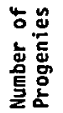 & 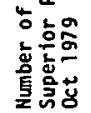 & 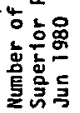 & 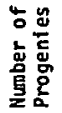 & 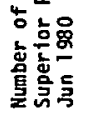 & \\
\hline
\end{tabular}

$$
\begin{aligned}
& \text { Cultivars } \\
& \text { Arriba } \\
& \text { Barton } \\
& \text { Flintlock } \\
& \text { Mandan } 456 \\
& \text { Rosana }
\end{aligned}
$$

(subtotal)

$\begin{array}{rrrrr}3 & & 3 & 5 & 2 \\ 7 & & 3 & 1 & 1 \\ 5 & & 1 & 3 & 2 \\ \frac{3}{22} & - & \frac{3}{16} & \frac{14}{14} & \frac{3}{17}\end{array}$

$\begin{array}{r}2 \\ 1 \\ 2 \\ 3 \\ 9 \\ \hline 17\end{array}$

Accessions (SCS)

Collections

Total Progenfes

10

Correlations

1979-1980

$$
\begin{array}{llllll}
17 & 7 & 11 & 27 & 14 & 57
\end{array}
$$

$\begin{array}{llllll}49 & 28 & 26 & 62 & 35 & 55\end{array}$

tThose above 3.0 or 3.5 on a $0-4$ vigar score at dates shown. 1978 group in three replications, 1979 group in two replications. scorrelation between 0ct 1979 mean of each progeny and its Jun 1980 mean.

Isignificant at pe.001.

Since seed of the synthetic WWG-96 (made up of 96 plants found to be superior for seed traits in the nurseries) was harvested in 1980, it was included in a new test with several checks. The test included two cultivars, Arriba and Rosana, and five products from recent breeding by $F$. Quinones of New Mexico State University (Quinones 1979). This performance test of eight entries was planted in the a) ley spaces of the ISS legume/grass plot in October 1980. The three randomized blocks each included eight 3 -row plots $(4.88 \times .91 \mathrm{~m})$ with 375 seed planted per row at $2.5 \mathrm{~cm}$ depth by a one-row conetype drill seeder. 


\section{Indian Ricegrass}

The strain test planted in fall 1976 used available seed of cultivars, accessions, and a few native collections. The best for vigor, growth, and survival were Sharps, Warners, M-700, and NM-168. One progeny test was planted in November 1978 and another in April 1979, both of which have yielded valuable data on the 34 progenies (only 22 of them were repeated in April) contained in the three replications at the ISS. In both lists, highly significant differences among the progenies were scored (0-5 basis) in October 1979 and May 1980. The scores on those dates were significantly correlated at .61 and .58 for the two plantings.

Choice of parents was made tentatively in 1979 as shown by those 16 scoring over 3.7 in October 1979 (Table 38, p. 57, C00-4018-4). These choices were revised to reflect new data in 1980 resulting from some eliminations and the addition of one parent from the SC-1 Piceance Basin. Table 43 shows the origins of the 11 parents included in Group 1 and Group 2 bulks this year. Performance is not less in the collections than in the cultivars, and good parents have been found among NM accessions.

A preliminary adaptation test of five collections from western Colorado and four from Or. Lang in Wyoming (June 1978) revealed good emergence for two entries, J-5 and Lang-8, and fair emergence for $\mathrm{PB}-11$ (this test was destroyed by rodents). Progenies from nursery spaced plants of some of the same series of collections previously listed in Table 39.were seeded December 1979 in the Intensive study site and gave results shown in Table 44 . At this time it is hard to decide which progeny among

Table 43. Indian ricegrass progeny tests at the Intensive Study site: . proportion showing superior performance over the 19791980 period.

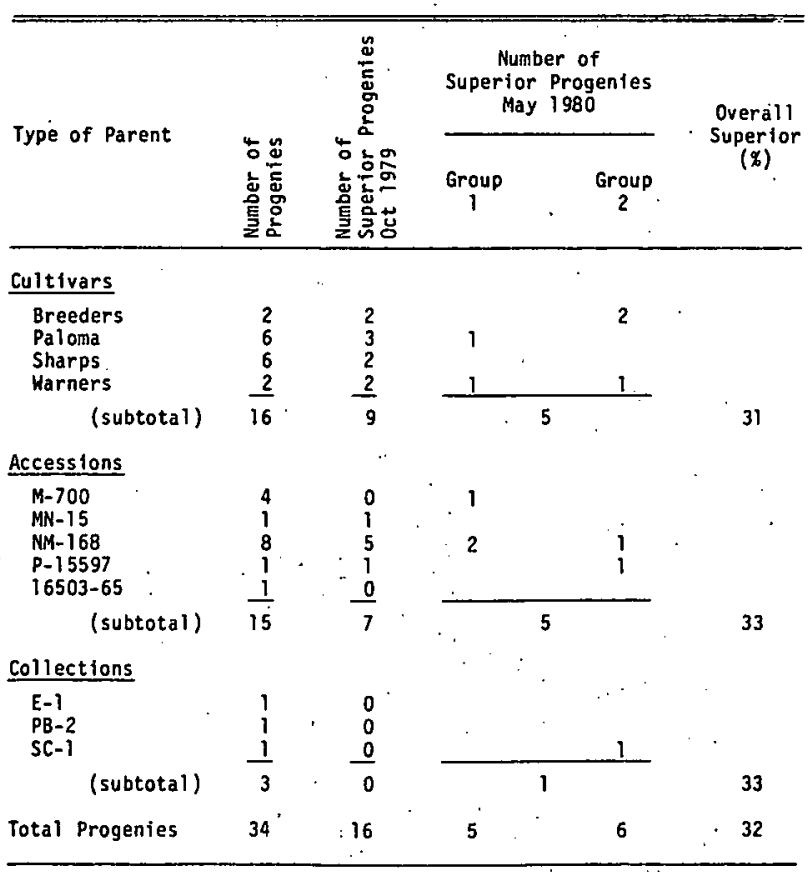

the three marked is best because of the low correlation between June 1980 and September 1980 readings.

Table 44: Progeny test of selected plants from native Indian ricegrass collections sown December 1979 at ISS.

\begin{tabular}{|c|c|c|c|c|}
\hline Parent & 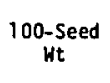 & $\begin{array}{c}\text { Emergence } \\
\text { Score }{ }^{\dagger} \\
\text { Jun } 1980\end{array}$ & $\begin{array}{c}\text { Vigor } \\
\text { Scoret } \\
\text { Sep } 1980\end{array}$ & Superior $\delta$ \\
\hline$J-3-8-5$ & 327 & 1.3 & 2.7 & \\
\hline$J-5-4-3$ & 329 & 3.0 & 2.3 & \\
\hline Lang-8-4-1 & 407 & 2.0 & 1.7 & \\
\hline Lang-8-7-2 & 413 & 3.3 & 2.0 & \\
\hline Lang-8-7-3 & 395 & 4.0 & 2.0 & + \\
\hline Lang-37-1-5 & 365 & 2.0 & 4.0 & + \\
\hline$P B-11-8-3$ & 355 & $3.0^{\circ}$ & 3.0 & + \\
\hline$P B=17-3-5$ & 465 & 1.7 & 1.0 & . \\
\hline \multicolumn{2}{|c|}{ Significant Difference } & * & $*$ & \\
\hline \multicolumn{2}{|c|}{$\begin{array}{l}\text { Correlation Jun } 1980 \\
\text { with Sep } 1980\end{array}$} & \multicolumn{3}{|c|}{+0.1 (not significant) } \\
\hline
\end{tabular}

tscored on a $0-4$ basis, mean of three replications. $\star$, $*=$ significant at .05 and .01 , respectively.

SSuperior progenies.

In order to compare composites of Groups 1 and 2 with other products of this and other programs, especially that of Quinones in New Mexico which produced the L.C. -5 composite (Quinones 1979), a performance test was planted october 1980 at the Intensive Study site in disturbed topsoil-subsoil. The two cultivars Paloma 74 and Nezpar (Booth et al. $1980)$ serve as checks for 12 other entries including IRG-5 (Group 1), IRG-6 (Group 2), IRG-1 (our five-variety combination), and L.C. -5 composite and its eight component lines. The four randomzied blocks each contain two-row plots $(2 x .6 \mathrm{~m})$ of the entries with 250 machine-scarified seed planted per row at a depth of $2.5 \mathrm{~cm}$ by a one-row cone-type drill seeder.

\section{Legumes}

Strain Test of Native and Introduced Legumes

The test of one to seven strains of each of eight species of native sweetvetch, lupine, and purple prairieclover (Petalostemon purpurezon)(the latter from the Kansas-Nebraska plains) and introduced cicer milkvetch (Astragalus cicer)(Townsend 1979), crownvetch (Coronizla varia), sainfoin (Onobrychis viciaefolia), alfalfa (Medicago sativa), and Swainson's pea (Sphaerophysa salsula) was seeded in October 1978 in paired rows on each soil type (topsoil and subsoil) in the legume plot at the Intensive Study Site. Seeds were scarified and inoculated with either commercial inoculum or soil from under plants of that species. Rows were $1 \mathrm{~m}$ apart and $2 \mathrm{~m}$ long, and one row of the pair was intended for destructive sampling needed to do acetylene reduction assay on roots and nodules (Seetin and Barnes 1977, Duhigg et al. 1978). 
Vigor was scored twice in 1979 (only the fall score reported) and twice in May and September 1980. Flowering was scored in June 1980 and notes made on seed setting in the conditions of the Intensive Study Site. Although these are all perennial species some of which have rhizomatous growth potential, regeneration by seed could be important in succession. Moreover, use of this plot as a selection nursery to produce seed of the best strains depends upon the seed-maturation event.

Growth in the first season (1979) was recorded on September 9, 1979, in the form of vigor scores on a scale of $0-6$. Sainfoin and al falfa showed luxuriant growth of about $50 \mathrm{~cm}$ height, which was beginning to go dormant. The cicer milkvetch did not show the onset of dormancy at that date. Overwintering of legumes requires some channeling of reserves to the crown. In fact, no problem occurred with any species; they were all alive and flourishing in May 1980 when the vigor was scored again (Table 45). Note that the 1980 scores were made by comparison within that date. Growth of sainfoin, again the most vigorous, reached $90 \mathrm{~cm}$ to $100 \mathrm{~cm}$; the growth of sweetvetch reached $40 \mathrm{~cm}$ to $50 \mathrm{~cm}$. As in 1979 there was no overall difference between plants seeded in topsoil and in subsoil. Lupines showed somewhat better growth in the silty topsoil. In all comparisons strains showed highly significant $(p=.001)$ differences for vigor and flowering. The vigor scores for September 1980 showed effects of summer drought; almost every species showed more green growth in plants in the subsoil, presumably because it held more moisture than topsoil.

There was significant $(p=.10)$ interaction between soil type and strain for flowering. Thus, sweetvetch flowered earlier on subsoil, while lupines and crownvetch flowered earlier on topsoil. The scores in Table 45 have these meanings: 0 for no bloom, 1 for $10 \%$ bloom, 2 for $30 \%$ to $40 \%$ bloom, 3 for $70 \%$ bloom, and 4 for full bloom on all plants in the row. Alfalfa is clearly a later bloomer than sainfoin in this experiment. Both those species and cicer milkvetch set seed during the summer, but the many inflorescences on sweetvetch and lupine shed most of their flowers at an early pod stage leaving bare branch axes. This phenomenon has been seen before in the Piceance Basin as well as at Fort Collins and is believed to be a combination of pollinator ineffectiveness and moisture stress during pod fill. This is a problem in making original collections as well as multiplying seed supplied of native legumes. Another prob$1 \mathrm{em}$ is the delay into the second (or even third) growing season before profuse flowering takes place. Sweetvetch flowered in the second season at the Intensive Study Site, setting a few seed only on the subsoil, whereas our replicated nursery rows at Meeker (from the same late 1978 seeding) were still vegetative in 1980 . Only two rows at ISS produced as much as $4.8 \mathrm{~g}$ from $4 \mathrm{~m}$ (about 800 smallish seeds), and this was the ISS collection which was a very local type. The next best was a plot of Stewart and Sons' seed source with $2.4 \mathrm{~g}$ (about $500 \pm$ immature seed). These are compared to $10 \mathrm{~g}$ or $20 \mathrm{~g}(1,000$ to 2,000 plump seed) from a single spaced plant at the Fort Collins nursery which could be extrapolated to seed production of $200 \mathrm{~kg} / \mathrm{ha}$.
Table 45. Performance of native and introduced legumes in the strain test at ISS (seeded October 1978) through 1979 and 1980.

\begin{tabular}{|c|c|c|c|c|c|c|c|}
\hline \multirow{2}{*}{ Species and Strain } & \multicolumn{2}{|c|}{$\begin{array}{c}\text { Vigort } \\
\text { oct } 9,1979\end{array}$} & \multicolumn{2}{|c|}{$\begin{array}{c}\text { Vigort } \\
\text { May } 31,1980\end{array}$} & \multicolumn{2}{|c|}{$\begin{array}{r}\text { flowering } 5 \\
\text { Jun } 22,1980\end{array}$} & \multirow{2}{*}{$\begin{array}{l}\text { Seed } \\
\text { Produced }\end{array}$} \\
\hline & $\begin{array}{l}\text { Top- } \\
\text { soil }\end{array}$ & $\begin{array}{l}\text { Sub- } \\
\text { soli }\end{array}$ & $\begin{array}{l}\text { Top- } \\
\text { soil }\end{array}$ & $\begin{array}{l}\text { Sub- } \\
\text { soli }\end{array}$ & $\begin{array}{l}\text { Top- } \\
\text { soil }\end{array}$ & $\begin{array}{l}\text { Sub- } \\
\text { soil }\end{array}$ & \\
\hline \multicolumn{8}{|l|}{ Sweetvetch } \\
\hline $\begin{array}{l}\text { ISS Piceance Basin : } \\
\text { E/ISS Piceance Basinx } \\
\text { Pipelfne Piceance Basin } \\
\text { Stewart (Utah) } \\
\text { Native Plants (Utah) }\end{array}$ & $\begin{array}{l}3.2 \\
2.8 \\
2.0 \\
3.8 \\
4.5 \\
\end{array}$ & $\begin{array}{l}3.5 \\
3.2 \\
3.2 \\
4.2 \\
4.2 \\
\end{array}$ & $\begin{array}{l}3.5 \\
2.8 \\
3.0 \\
4.0 \\
4.0 \\
\end{array}$ & $\begin{array}{l}3.5 \\
3.2 \\
3.0 \\
3.8 \\
3.0 \\
\end{array}$ & $\begin{array}{l}2.2 \\
1.8 \\
2.2 \\
2.2 \\
1.5 \\
\end{array}$ & $\begin{array}{l}3.2 \\
3.0 \\
3.5 \\
3.2 \\
4.0 \\
\end{array}$ & $\begin{array}{l}800 \\
200 \\
500 \\
400 \\
\cdots\end{array}$ \\
\hline Mean & 3.3 & 3.7 & 3.4 & 3.3 & 2.1 & 3.3 & \\
\hline \multicolumn{8}{|l|}{ Lupine } \\
\hline \multirow[t]{2}{*}{$\begin{array}{l}031 \\
142 \\
225 \\
232\end{array}$} & $\begin{array}{l}4.5 \\
4.0 \\
3.5 \\
1.5 \\
\end{array}$ & $\begin{array}{l}2.0 \\
3.0 \\
2.5 \\
1.0 \\
\end{array}$ & $\begin{array}{l}2.5 \\
3.0 \\
1.0 \\
2.0 \\
\end{array}$ & $\begin{array}{l}0.8 \\
1.5 \\
1.5 \\
1.0 \\
\end{array}$ & $\begin{array}{l}1.0 \\
3.0 \\
2.0 \\
1.0\end{array}$ & $\begin{array}{l}0.0 \\
0.0 \\
3.5 \\
0.0 \\
\end{array}$ & $\begin{array}{c}\cdots \\
22 \\
\cdots\end{array}$ \\
\hline & 3.4 & 2.1 & 2.1 & 1.2 & 1.8 & 0.9 & \\
\hline \multicolumn{8}{|l|}{ Cicer milkvetch } \\
\hline \multirow[t]{2}{*}{$\begin{array}{l}\text { Lutana } \\
\text { Monarch } \\
\text { C-4 } \\
\text { Dotzenko } \\
\text { Sugarbeet } 2 \\
\text { Weilington } \\
20-15\end{array}$} & $\begin{array}{l}3.0 \\
4.0 \\
4.0 \\
4.0 \\
4.3 \\
4.5 \\
4.0 \\
\end{array}$ & $\begin{array}{l}4.3 \\
4.3 \\
4.3 \\
5.0 \\
5.0 \\
4.3 \\
5.0 \\
\end{array}$ & $\begin{array}{l}2.5 \\
3.5 \\
3.5 \\
4.0 \\
4.0 \\
4.0 \\
3.2 \\
\end{array}$ & $\begin{array}{l}3.5 \\
3.5 \\
3.8 \\
4.0 \\
3.5 \\
3.8 \\
4.0 \\
\end{array}$ & $\begin{array}{l}0.2 \\
0.5 \\
1.2 \\
1.0 \\
1.0 \\
0.5 \\
1.0 \\
\end{array}$ & $\begin{array}{l}1.8 \\
0.5 \\
0.5 \\
1.0 \\
1.0 \\
0.2 \\
2.0 \\
\end{array}$ & \\
\hline & 4.0 & 4.7 & 3.5 & 3.7 & 0.8 & 1.0 & seed \\
\hline \multicolumn{8}{|l|}{ Cromnvetch } \\
\hline \multirow[t]{2}{*}{$\begin{array}{l}\text { Penngift } \\
\text { Emerald } \\
\text { Chemung }\end{array}$} & $\begin{array}{l}3.2 \\
2.5 \\
3.2 \\
\end{array}$ & $\begin{array}{l}3.5 \\
2.8 \\
2.5 \\
\end{array}$ & $\begin{array}{l}2.5 \\
2.2 \\
2.5 \\
\end{array}$ & $\begin{array}{l}2.2 \\
2.8 \\
2.0 \\
\end{array}$ & $\begin{array}{l}0.8 \\
1.3 \\
0.3 \\
\end{array}$ & $\begin{array}{l}0.8 \\
0.2 \\
0.0 \\
\end{array}$ & \\
\hline & 3.0 & 2.9 & 2.4 & $\overline{2.3}$ & $\overline{0.8}$ & 0.3 & \\
\hline \multicolumn{8}{|l|}{ Sainfoin } \\
\hline \multirow[t]{2}{*}{$\begin{array}{l}\text { Eski } \\
\text { Melrose } \\
\text { Remont }\end{array}$} & $\begin{array}{l}5.0 \\
5.9 \\
4.8 \\
\end{array}$ & $\begin{array}{l}5.0 \\
4.8 \\
5.2 \\
\end{array}$ & $\begin{array}{l}5.5 \\
5.5 \\
5.2 \\
\end{array}$ & $\begin{array}{l}5.0 \\
4.8 \\
5.5 \\
\end{array}$ & $\begin{array}{l}4.0 \\
4.0 \\
4.0 \\
\end{array}$ & $\begin{array}{l}4.0 \\
3.0 \\
4.0 \\
\end{array}$ & \\
\hline & 4.9 & 5.0 & 5.4 & 5.1 & 4.0 & 3.7 & seed \\
\hline \multicolumn{8}{|l|}{ Purple prairfeclover } \\
\hline Kaneb & 2.8 & 2.0 & 0.4 & 0.1 & 0.0 & 0.5 & $\cdots$ \\
\hline \multicolumn{8}{|l|}{ Alfalfa } \\
\hline Ladak & 5.0 & 4.0 & 5.3 & 5.3 & 2.0 & 1.2 & seed \\
\hline \multicolumn{8}{|l|}{ Swainson's pea } \\
\hline San Luls Valley & 4.0 & 3.5 & 2.5 & 1.5 & 0.0 & 0.0 & $\cdots$ \\
\hline
\end{tabular}

tScored $0-6$ with 6 the highest.

5 scored $0-4$ with 4 representing the full bioom.

Tcollected inside the fence at the Intensive study site, Piceance Basin. - Collected east of the Intensive Study Site. Piceance Basin.

\section{Nitrogen Fixation Study}

The object of this study is to evaluate (over the course of one year) the nitrogen fixing potential of cicer milkvetch, sweetvetch, sainfoin, and alfalfa on land disturbed by oil shale extraction.

The plots were established in October 1978 at the Piceance Basin in northwestern Colorado on the Intensive Study Site. Half of the plot area was covered with subsoil from the sagebrush community, and the other half was covered with topsoil similarly obtained. The legumes were inoculated and seeded into $2-\mathrm{m}$ rows spaced $1 \mathrm{~m}$ apart. Two replicates were planted on each soil type, but only the sainfoin was assayed in duplicate.

In September 1980 the first set of data was collected. The standard acetylene reduction method was employed in the field to measure the amount of ethylene evolved from the legume root systems with their nodules. Because the silty clay textured soil was fairly moist, the roots were not rinsed in water prior to incubation; instead, the soil was 
removed by shaking and sifted to collect loose nodules and small root pieces which were placed with the large roots and attached nodules in mason jars for incubation in $10 \%$ scrubbed acetylene and 90\% air atmosphere for three hours at ambient temperature $\left(13^{\circ}-18^{\circ} \mathrm{C}\right)$. Nodules were taken from the roots, dried, and weighed to determine the basis of acetylene reduction per $\mathrm{mg}$ of nodule dry weight and to investigate nodulation rate of different legume strains (Gibson 1962). We are grateful to Darwin Sorensen for sharing methodology and analytical detail.

Table 46 shows that sainfoin had the highest weight of large rosette-shaped nodules and sweetvetch the lowest per plant unit (the material dug within $15 \mathrm{~cm}$ radius from the stem, $45 \mathrm{~cm}$ deep). On the other hand, reduction rates per mg nodule dry weight are smaller in sainfoin than any other species, and one accession of sweetvetch has a rate almost as high as alfalfa. Except in sainfoin, rates on topsoil plots are higher than rates on subsoil plots; but any further interpretation is not warranted by this first set of data. We expect to get better replicate data sets in May, July, and August of 1981 to test the response to seasonal. moisture and temperature. The late summer of 1980 was rather dry at this $2,000-m$ site.

\section{Recombination of Selected Material}

The outcome of a selection program which includes source testing and progeny testing is not merely the information on which materials are best, but primarily their recombination in to an improved synthetic strain which includes a higher genetic base. Such a strain can be multiplied for direct use, through the channels of the seed industry, by the reclamation contractor. The new synthetic can also serve as the basis for new selective advance, a process known as recurrent selection (used in the low-dormancy project on Indian ricegrass).

Before formal release of a new variety (but during its initial multiplication) performance testing against existing varieties (Hanson 1972) is customany, in fact mandatory, in several locations and over more than one year. This testing period is the responsibility of the breeder or selector and agronomists; it was not considered to be a part of the original five-year DOE contract which included only the selection and recombination phases or what might reasonably be expected, notwithstanding weather vagaries, to be accomplished in five years. In the following, it will be seen how close we have come to accomplishing this fourth objective.

\section{Western Wheatgrass}

Decision on which mother plants to recombine depended on the data collected in Objectives 2 and 3 (the nurseries and the ISS tests) since both are vital to reclamation usefulness. The choice of 66 potential elite clones. of one group and 96 of another group overlapped the testing of 108 progenies in April 1978, 49 in November 1978 , and 62 in December 1979. Enough data were gathered from the ill-advised spring 1978 planting to show that some of the 66 clones were unsuited because of Canadian
Table 46. Acetylene reduction by legumes in the Piceance Basin, Colorado, September 1980.

\begin{tabular}{|c|c|c|c|c|}
\hline \multirow[b]{2}{*}{ Spectes and Strain } & \multirow[b]{2}{*}{ Soll Type } & \multirow[b]{2}{*}{$\begin{array}{c}\text { mg } \\
\text { nodules } \\
\text { plant-1 } \\
\text { (dry wt) }\end{array}$} & \multicolumn{2}{|c|}{$\mathrm{C}_{2} \mathrm{H}_{2}$ Reduced } \\
\hline & & & 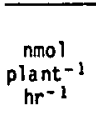 & $\begin{array}{c}\text { nmolt } \\
\text { mg-1 } \\
\text { nodule } \\
\text { dry wt } \\
h r^{-1}\end{array}$ \\
\hline
\end{tabular}

Cicer milkvetch

$\begin{array}{lllll}\text { Dotzenko } & \text { subsoil } & 20 & 94 & 4.7 \\ \text { Lutana } & \text { subsoil } & 25 & 139 & 5.6 \\ \text { Monarch } & \text { subsoil } & -- & 111 & -- \\ \text { Dotzenko } & \text { topsoil } & 20 & 599 & 30.0 \\ \text { Lutana } & \text { topsoil } & 24 & 273 & 11.4 \\ \text { Monarch } & \text { topsoil } & 22 & <10 & \end{array}$

Sweetvetch

$\begin{array}{lrrrr}\text { ISS } & \text { subsoil } & - & <10 & \ldots \\ \text { Pipeline } & \text { subsoil } & 12 & 76 & 6.3 \\ \text { Stewarts } & \text { subsoil } & -- & 257 & -.- \\ \text { ISS } & \text { topsoil } & 5 & 921 & 184.2 \\ \text { Pipeline } & \text { topsoil } & 13 & 196 & 15.1 \\ \text { Stewarts } & \text { topsoil } & 40 & 603 & 6.3\end{array}$

Sainfoin (mean of two replications)

$\begin{array}{lrrrr}\text { Eski } & \text { subsoil } & 737 & 6533 & 8.9 \\ \text { Melrose } & \text { subsoil } & 810 & 2767 & 3.7 \\ \text { Remont } & \text { subsoil } & 1147 & 330 & 0.3 \\ \text { Eski } & \text { topsoil } & 1012 & 217 & 0.2 \\ \text { Melrose } & \text { topsoil } & 2056 & 131 & 0.1 \\ \text { Remont } & \text { topsoil } & 1024 & 2022 & 2.0\end{array}$

Alfalfa

\begin{tabular}{rrrrr} 
Ladak & subsoil & 60 & 687 & 11.4 \\
Ladak & topsoil & 247 & 62380 & 252.6 \\
\hline
\end{tabular}
tThis unit of measurenent is the same as umol $\mathrm{g}^{-1}$ nodule
dry wt $\mathrm{hr}^{-1}$.

origin (p. $210,(00-4018-3$ ). Others of the 66 were, in fact, represented among the 96 clones; therefore, a recombination block with three replications of pieces of the 96 clones was planted in spring 1979 and harvested for seed in early August 1980. This synthetic will be known as WWG-96 and has been planted in a performance test at the Intensive Study Site in October 1980.

The newly confirmed data from the 1980 growing season of the 49 progenies and the 62 progenies allow the redefinition of the $96-\mathrm{cl}$ one synthetic to include only 26 of 49 and 35 of 62 , respectively. This means that the redefined synthetic WWG-64 is better defined for Picenace Basin response.

\section{Indian Ricegrass}

Consideration of the best method to combine gemplasm in Indian ricegrass has been a little 
different than in western wheatgrass. From the early (1976) strain tests it appared that five varieties were very promising; therefore, a fivevariety recombination block was made up in 1978 which yielded seed in 1979 and 1980. Seed from this recombination is included in the performance test (planted October 1980) along with the next two items.

Progeny testing at the ISS identified two groups of progenies among the 34 tested during 1979 and 1980. The groups of "five good" and "six best" were constituted by harvesting seed from these good-seed-setting rows in the two bulks from the test plot at the ISS. These two bulks were planted in October 1980 in a new test. All 11 of the elite mother clones of these progenies were set in two recombination blocks in August 1980, one in the greenhouse and the other in the field, and are scheduled to produce seed of a new synthetic Indian ricegrass with proven adaptation to the Picenace Basin conditions.

The low-dormancy recombination (second cycle of recurrent selection for lowered dormancy) was planted in June 1980 and should produce the first crop of seed in June 1981 .

\section{Legumes}

Since progeny evaluations are less advanced, the making of synthetics is also further in the future except for the recombination of the first cycle for seed yield in sweetvetch which was planted in June 1980. When seed yield data are obtained in the 1981 crop, decisions can be made to let only the best of those plants flower and set seed in 1982; this would be the basis of a synthetic for reliable seed production in sweetvetch. This would need to be performance-tested in Piceance Basin conditions along with other relevant material from Utah programs.

\section{LITERATURE CITED}

Assay, K. H., D. A. Johnson, and D. R. Dewey. 1978. Breeding grasses for western range. Utah Sci. $39: 3-5$.

Booth, D. Terrance, Charles G. Howard, and Charles E. Mowry. 1980. "Nezpar" Indian ricegrass: Description, justification of release, and recommendations for use. Rangelands 2: 53-54.

Cuany, R. L., and A. L. Wilson. 1979. Breeding native western grasses for seed production, seed size, and adaptation to revegetation uses. Proc. 25th Grass Breeders' Work Plan Conf.: 15.

Duhigg, D., 8. Melton, and A. Baltensperger. 1978. Selection for acetylene reduction rates in "Mesilla" alfalfa. Crop Sci. 18:813-816.

Gibson, A. H. 1962. Genetic variation in the effectiveness of nodulation of lucerne varieties. Aust. J. Agric. Res. 13:388-399.
Hanson, A. A. 1972. Grass varieties in the United States. U.S. Dep. Agric., Agric. Res. Serv., Agric. Handb. 170.124 pp.

Kenny, Stephen T. 1981. Lupinus argenteus and allies: Potential for domestication and improvement for revegetation uses. Ph.D. Thesis. Colo. State Univ., Ft. Collins. In preparation.

McDonald, M. B., Jr., and A. A. Khan. 1978. Metabolic changes in Indian ricegrass seeds in relation to coat-imposed and embryonal dormancy. Agron. J. 70:829-835.

Northstrom, Terry E., and Stan1ey L. Welsh. 1970. Revision of the Hedysarum boreale complex. Great Basin Nat. 30:109-130.

Padilla, W. W. 1978. Evaluating western wheatgrass sources for oil shale land revegetation. M.S. Thesis. Colo. State Univ., Ft. Collins.

Quinones, F. A. 1979. Range grass breeding work. Proc. 25th Grass Breeders' Work Plan Conf.: 27.

Rogler, G. 1954. Seed size and seedling vigor in crested wheatgrass. Agron J. 46:216-220.

Schaaf, H. 1976. Space-planted and mass-seeded progeny tests for seed yield and seed size in tetraploid crested wheatgrass. Crop Sci. 16: 607-610.

Schaaf, H. M., and G. A. Rogler. 1970. Registration of Lodorm green needlegrass. Crop Sci. $10: 726-727$.

Seetin, N. W., and D. K. Barnes. 1977. Variation among alfalfa genotypes for rates of acetylene reduction. Crop Sci. 17:783-787.

Townsend, C. E. 1979. Breeding cicer milkvetch for improved seedling emergence. Crop Sci. 19:613-616.

Zemetra, Robert S., and Robin L. Cuany. 1981. Variation in seed covering thickness of Indian ricegrass and its effects on seed dormancy. Crop Sci. Submitted.

Zemetra, Robert S., Cynthia Havstad, and Robin L. Cuany. 1981. Reducing seed dormancy in Indian ricegrass, Oryzopsis hymenoides. J. Range Manage. Submitted.

\section{AVAILABLE PUBLICATIONS ANO/OR ABSTRACTS}

Cuany, R. L. 1977. Grasses and legumes for revegetation and multiple uses in Colorado. Proc. 24th Grass Breeders' Work Plan Conf. Tifton, Ga., July. (Abstr.)

Cuany, R. L., W. Padilla, and S. Kenny. 1977. Grass and legume improvement for revegetation of disturbed 1ands. Colo. State Univ., Exp. Stn., 90th Annu. Res. Conf. (Abstr.) 
Padilla, W. W., R. L. Cuany, and G. P. Murray.

1978. Seed production characters in selection of western wheatgrass for revegetation uses. Agron. Abstr. 1978:111:

Zemetra, R. S., and R. L. Cuany. 1978. Reducing seed dormancy in Indian ricegrass for disturbed land reclamation. Agron. Abstr. 1978:114.

Zemetra, R., and R. L. Cuany. 1979: Variation in seed coat unit thickness of Indian ricegrass and its effect on seed dormancy. Agron. Abstr. 1979:118.

Cuany, R. L., and A. M. Wilson. 1979. Breeding native western grasses for seed production, seed size, and adaptation to revegetation uses. Proc.. 25th Grass Breeders' Work Plan Conf. Lexington, Ky., May. (Abstr.) 